\title{
De arbeidsmarkt naar opleiding en beroep tot 2020
}

Citation for published version (APA):

Bijlsma, I., van Broekhoven, K. C. M., Collewet, M. M. F., Cörvers, F., Dijksman, S., Fouarge, D., KünnNelen, A. C., \& Poulissen, D. (2015). De arbeidsmarkt naar opleiding en beroep tot 2020. ROA. ROA

Reports No. 006 https://doi.org/10.26481/umarep.2015006

Document status and date:

Published: 01/01/2015

DOI:

10.26481/umarep.2015006

Document Version:

Publisher's PDF, also known as Version of record

\section{Please check the document version of this publication:}

- A submitted manuscript is the version of the article upon submission and before peer-review. There can be important differences between the submitted version and the official published version of record.

People interested in the research are advised to contact the author for the final version of the publication, or visit the DOI to the publisher's website.

- The final author version and the galley proof are versions of the publication after peer review.

- The final published version features the final layout of the paper including the volume, issue and page numbers.

Link to publication

\footnotetext{
General rights rights.

- You may freely distribute the URL identifying the publication in the public portal. please follow below link for the End User Agreement:

www.umlib.nl/taverne-license

Take down policy

If you believe that this document breaches copyright please contact us at:

repository@maastrichtuniversity.nl

providing details and we will investigate your claim.
}

Copyright and moral rights for the publications made accessible in the public portal are retained by the authors and/or other copyright owners and it is a condition of accessing publications that users recognise and abide by the legal requirements associated with these

- Users may download and print one copy of any publication from the public portal for the purpose of private study or research.

- You may not further distribute the material or use it for any profit-making activity or commercial gain

If the publication is distributed under the terms of Article $25 \mathrm{fa}$ of the Dutch Copyright Act, indicated by the "Taverne" license above, 


\section{De arbeidsmarkt naar opleiding en beroep}

\section{tot 2020}

\section{ROA Rapport}

ROA-R-2015/6

Researchcentrum voor Onderwijs en Arbeidsmarkt | ROA Research Centre for Education and the Labour Market | ROA 


\section{DE ARBEIDSMARKT NAAR OPLEIDING EN BEROEP TOT 2020}

ROA-R-2015/6 


\section{Colofon}

(C) Researchcentrum voor Onderwijs en Arbeidsmarkt (ROA). Niets uit deze uitgave mag op enige manier worden verveelvoudigd zonder voorafgaande schriftelijke toestemming van de directeur van het ROA.

\section{Researchcentrum voor Onderwijs en Arbeidsmarkt}

School of Business and Economics

Maastricht University

\section{Vormgeving}

ROA secretariaat, Maastricht

\section{Verkoop}

Researchcentrum voor Onderwijs en Arbeidsmarkt email: secretary-roa-sbe@maastrichtuniversity.nl

website: www.roa.nl

ISBN: 978-90-5321-543-2 


\section{INHOUD}

Ten geleide $\quad$ v

Samenvatting vii

Doel en opzet van de arbeidsmarktprognoses xiii

01 De arbeidsmarkt in vogelvlucht $\quad 1$

$\begin{array}{ll}1.1 \text { Inleiding } & 1\end{array}$

$\begin{array}{ll}\text { 1.2 Actuele situatie en verwachte ontwikkeling } & 1\end{array}$

1.3 Verwachtingen voor arbeidsvraag en -aanbod op de middellange termijn 14

$\begin{array}{ll}\text { 1.4 Werkgelegenheidsontwikkeling naar bedrijfssector } & 17\end{array}$

1.5 Werkgelegenheidsontwikkeling naar beroepsklasse $\quad 19$

1.6 Werkgelegenheidsontwikkeling naar opleidingsniveau 20

$\begin{array}{ll}\text { 1.7 Toekomstige arbeidsmarktperspectieven naar opleidingsniveau } & 21\end{array}$

$\begin{array}{ll}1.8 \text { Conclusie } & 24\end{array}$

02 Ontwikkelingen in vraag en aanbod 2015-2020 27

$\begin{array}{ll}2.1 \text { Inleiding } & 27\end{array}$

2.2 Uitbreidingsvraag $\quad 28$

$\begin{array}{ll}2.3 \text { Vervangingsvraag } & 34\end{array}$

$\begin{array}{ll}2.4 \text { Baanopeningen } & 41\end{array}$

2.5 Arbeidsmarktinstroom $\quad 45$

$\begin{array}{ll}2.6 \text { Conclusie } & 48\end{array}$

03 Aansluiting tussen onderwijs en arbeidsmarkt $\quad 51$

$\begin{array}{ll}3.1 \text { Inleiding } & 51\end{array}$

3.2 Aansluiting onderwijs-arbeidsmarkt van recent afgestudeerden $\quad 51$

3.3 Toekomstige arbeidsmarktperspectieven naar opleiding 66

3.4 Toekomstige knelpunten in de personeelsvoorziening naar beroep $\quad 72$

3.5 Conclusie $\quad 76$ 
04 Verschuivingen in de beroepenstructuur 1996-2014

$\begin{array}{ll}4.1 \text { Inleiding } & 79\end{array}$

4.2 Beroepenstructuur 1996-2014 81

4.3 Opleidingsstructuur van beroepen 1996-2014 86

4.4 Leeftijdssamenstelling van beroepsgroepen 1996-2014 90

$\begin{array}{ll}4.5 \text { Conclusie } & 94\end{array}$

05 Arbeidsmarktpositie en -perspectieven van arbeidsgehandicapten $\quad 97$

$\begin{array}{ll}5.1 \text { Inleiding } & 97\end{array}$

5.2 De positie van arbeidsgehandicapten in Nederland 100

5.3 Subjectieve arbeidsmarktuitkomsten van arbeidsgehandicapten $\quad 113$

$\begin{array}{ll}\text { 5.4 Arbeidsmarktperspectieven } & 117\end{array}$

$\begin{array}{ll}5.5 \text { Conclusie } & 121\end{array}$

Bijlage A Centrale begrippen bij de arbeidsmarktprognoses 123

Bijlage B Classificaties naar bedrijfssector, beroep en opleiding 131

Bijlage C Verkrijgbare arbeidsmarktinformatie per bedrijfssector,
beroepsgroep en opleidingstype

$\begin{array}{ll}\text { Bijlage D Leeftijdspiramide van de werkenden } & 145\end{array}$

$\begin{array}{ll}\text { Bljlage E Stellingen behorende bij de arbeidsomstandigheden } & 147\end{array}$ en arbeidsmarktuitkomsten 


\section{TEN GELEIDE}

Sinds het uitbreken van de economische crisis eind 2008 beleven wij roerige tijden op de Nederlandse arbeidsmarkt. Er zijn tekenen van herstel van de economische groei, maar de werkloosheid is nog steeds hoog. In deze aanhoudend roerige tijden op de arbeidsmarkt brengt het Researchcentrum voor Onderwijs en Arbeidsmarkt (ROA) de dertiende uitgave van het rapport De arbeidsmarkt naar opleiding en beroep uit. Hierin wordt een beeld geschetst van de huidige en op de middellange termijn te verwachten arbeidsmarktontwikkelingen. Wij schetsen de arbeidsmarktperspectieven voor de jaren tot 2020 onder andere om de jongeren die nu voor hun studiekeuze staan inzicht te bieden in de verwachte arbeidsmarktsituatie na afstuderen. Deze informatie is van belang voor zowel het geven van voorlichting aan degenen die aan een (vervolg)opleiding willen beginnen als voor werkgevers bij het nemen van strategische beslissingen over hun personeelsbeleid. Het rapport is in het bijzonder bedoeld voor de beleidsontwikkeling van de overheid, de arbeidsbemiddelingssorganisaties, de sociale partners en het onderwijsveld. Het is gebaseerd op gedetailleerde arbeidsmarktinformatie naar sector, beroep en opleiding, zoals deze is opgenomen in het Arbeidsmarktinformatiesysteem (AIS) van het ROA (http://roastatistics.maastrichtuniversity.nl/).

Het rapport is opgebouwd uit vijf hoofdstukken. De eerste drie hoofdstukken gaan over de actuele en verwachte ontwikkelingen op de arbeidsmarkt, gedifferentieerd naar sector, beroep en opleiding. Hoofdstuk 1 begint met een overzicht van de recente macro-economische ontwikkelingen in relatie tot de arbeidsmarkt, waarbij wordt ingegaan op het verband tussen werkloosheid en vacatures in Nederland. Tevens bevat het hoofdstuk informatie over het verdiende loon naar beroep om jongeren te kunnen informeren over het 'rendement' van hun investering in menselijk kapitaal en de financiële gevolgen van hun beroepskeuze. Vervolgens wordt een globaal overzicht gegeven van de verwachte arbeidsmarktontwikkelingen voor de periode 2015-2020. De verwachte ontwikkelingen in de uitbreidingsvraag, de vervangingsvraag, de baanopeningen en de arbeidsmarktinstroom worden in hoofdstuk 2 verder gedifferentieerd naar beroep en opleiding. In hoofdstuk 3 staat de aansluiting tussen onderwijs en arbeidsmarkt centraal. Hierbij wordt eerst ingegaan op de actuele aansluitingsproblematiek van recent gediplomeerden en vervolgens op de toekomstige arbeidsmarktperspectieven naar opleiding en de voor werkgevers te verwachten knelpunten in de personeelsvoorziening naar beroep. De laatste twee hoofdstukken van het rapport behandelen elk een thema dat relevant is voor de aansluiting tussen onderwijs en arbeidsmarkt. Hoofdstuk 4 gaat in op veranderingen in de beroepsstructuur, opleidingsstructuur en leeftijdssamenstelling van de beroepsbevolking. Hoofdstuk 5 bespreekt de arbeidsmarktkansen van 
arbeidsgehandicapten. Naar verwachting zal het aanbod van deze groep toenemen nu de Participatiewet in werking is getreden.

Aan het begin van dit rapport wordt ingegaan op de gebruiksdoelen van de prognoses en wordt een globaal overzicht gegeven van het gebruikte prognosemodel. Over de gehanteerde onderzoeksmethoden en de classificaties wordt verwezen naar de specifieke werkdocumenten en research memoranda van het ROA, met name het werkdocument Methodiek arbeidsmarktprognoses en -indicatoren 2015-2020.

De eindredactie van De arbeidsmarkt naar opleiding en beroep tot 2020 is in handen van dr. D. Fouarge. Aan hoofdstukken 1, 2 en 3 hebben I. Bijlsma MSc, K. van Broekhoven MSc, M. Collewet MSc, Prof. Dr. F. Cörvers, S. Dijksman BSc, dr. D. Fouarge, M. de Hoon MSc, dr. A. Künn-Nelen, D. Poulissen MSc en E. Sijbers MSc meegewerkt. Hoofdstuk 4 is geschreven door I. Bijlsma MSc, S. Dijksman BSc, dr. D. Fouarge en dr. A. Künn-Nelen. Hoofdstuk 5 is samengesteld door M. de Hoon MSc en dr. A. Künn-Nelen. Het bij dit rapport behorende geautomatiseerde Arbeidsmarktinformatiesysteem (AIS) is ontwikkeld door S. Dijksman BSc. Secretariële ondersteuning bij de totstandkoming van dit rapport is gegeven door W. Klein en M. Boere.

De rapportage vindt plaats in het kader van het door het ROA uitgevoerde Project Onderwijs-Arbeidsmarkt (POA) waarvan de projectleiding in handen van dr. D. Fouarge is. Dit project is ontstaan op initiatief van het ROA in 1986. Aan het Project OnderwijsArbeidsmarkt wordt financieel bijgedragen door het Ministerie van Onderwijs, Cultuur en Wetenschap (OCW), het Ministerie van Economische Zaken (EZ), het Ministerie van Binnenlandse Zaken en Koninkrijksrelaties (BZK), het Ministerie van Sociale Zaken en Werkgelegenheid (SZW), het UWV Werkbedrijf, de stichting Samenwerking Beroepsonderwijs Bedrijfsleven (SBB) en Randstad Nederland.

Wij zijn de leden van de begeleidingscommissie en de commissie van financiers dankbaar voor hun deskundige en enthousiaste begeleiding van het project: Prof. dr. $\mathrm{H}$. Ganzeboom (voorzitter begeleidingscommissie, Vrije Universiteit Amsterdam), drs. R. Baarda (stichting Samenwerking Beroepsonderwijs Bedrijfsleven SBB), drs. J. Brooijmans en B. van Krimpen MSc. (Randstad Nederland), H. Daale (Leido), drs. N. Achterberg (Ministerie van Sociale Zaken en Werkgelegenheid), drs. R. Hoffius (Ministerie van Onderwijs, Cultuur en Wetenschap), dr. F. van der Mooren (Centraal Bureau voor de Statistiek), drs. M. van Smoorenburg (UWV WERKbedrijf), drs. A. Stet (Ministerie van Binnenlandse Zaken en Koninkrijksrelaties), drs. U. Teunis (Ministerie van Economische Zaken, Landbouw en Innovatie), drs. drs. B. Verlaan (Ministerie van Onderwijs, Cultuur en Wetenschap), drs. M. Warmerdam (Ministerie van Onderwijs, Cultuur en Wetenschap), drs. D. de Graaf (Ministerie van Onderwijs, Cultuur en Wetenschap), W. van den Berge MSc (CPB) en drs. C. van Nahuijs (LDC).

Maastricht, december 2015

Prof. dr. A de Grip 


\section{SAMENVATTING}

\section{Werkgelegenheidsgroei}

Sinds de kredietcrisis van 2008 wisselen periodes van economische groei en krimp elkaar af. In de periode 2010-2014 is de arbeidsmarkt voor recent gediplomeerden verslechterd doordat het arbeidsaanbod ruim hoger lag dan het aantal vacatures voor starters. De werkloosheid onder recent gediplomeerden lag in 2014 met 8,8\% hoger dan in 2010 (4,7\%). Het loon van gediplomeerden lag in 2014 lager dan in 2010, en er is vaker sprake van verticale en/of horizontale mismatches. Maar er zijn ook een aantal positieve ontwikkeling te melden. Zo neemt de jeugdwerkloosheid de laatste twee jaar langzaam af. De arbeidsmarktprognoses voor de middellange termijn (van 2015 tot 2020) laten zien dat de werkgelegenheid met gemiddeld o,8\% per jaar zal groeien. Er is sprake van een toename van de werkgelegenheid met ca. 400 duizend personen in de periode 2015-2020. Er zullen de komende jaren naar verwachting dus meer banen bijkomen dan verdwijnen. De grootste werkgelegenheidsgroei wordt verwacht in de bouwsector (2,2\% per jaar). De economisch slechte tijden lijken hiermee voorbij te zijn voor deze sector. Voor de specialistische zakelijke dienstverlening wordt eveneens een grote groei verwacht ( $2,1 \%$ per jaar). Andere sectoren met een hoge verwachte werkgelegenheidsgroei zijn verhuur en overige zakelijke dienstverlening, en informatie en communicatie. In de sectoren landbouw, bosbouw en visserij, chemie en overige industrie, die in de jaren 1996-2014 een krimp lieten zien, zal de werkgelegenheid verder krimpen. Daarnaast wordt er een krimpende werkgelegenheid verwacht voor sectoren als energie, financiële dienstverlening en onroerend goed. Ook bij het openbaar bestuur en overheidsfinanciën zullen naar verwachting banen verdwijnen.

In de jaren 1996-2014 hebben de zorg- en welzijnssector een flinke werkgelegenheidsgroei meegemaakt ( $2,7 \%$ en $2,3 \%$ per jaar). De werkgelegenheidsgroei in deze sectoren wordt tot 2020 echter sterk geremd als gevolg van overheidsbezuinigingen, namelijk tot $0,2 \%$ per jaar in de zorgsector en $0,3 \%$ per jaar in de welzijnssector. Een kanttekening hierbij is dat de werkgelegenheidsprognoses voor beide sectoren vooral negatief uitpakken aan het begin van de prognoseperiode, met een herstel tegen het einde van de periode. 
De vervangingsvraag zal de komende jaren veruit de belangrijkste component vormen voor het aantal baanopeningen: er zal meer vervanging optreden op de arbeidsmarkt dan uitbreiding van de werkgelegenheid. De vervangingsvraag naar beroep is geschat op ruim 1,5 miljoen tot 2020. Dit wil zeggen dat er tot 2020 ruim 1,5 miljoen arbeidskrachten vervangen moeten worden door wisselingen van beroepsgroep en, al dan niet tijdelijk, uittreden van werkenden. Dit resulteert in een jaarlijks gemiddelde vervangingsvraag van $2,9 \%$. De verwachte vervangingsvraag is het hoogst voor de transporten logistiekberoepen en de agrarische beroepen. Bij beide sectoren gaat het echter om beroepen met een hoog aandeel scholieren met een bijbaan die vaak van beroep wisselen. Bij transport- en logistiekberoepen kan men denken aan beroepen zoals vakkenvuller en vuilnisophalers en dagbladenbezorgers. Bij agrarische beroepen gaat het vaak om seizoensgebonden arbeid. Het aantal baanopeningen zal relatief groot zijn voor deze sectoren, maar het aanbod van jonge scholieren met een bijbaan is ook groot waardoor er niet per se knelpunten in de personeelsvoorziening ontstaan voor werkgevers.

De geringe werkgelegenheidsgroei en de lage vervangingsvraag in de sector zorg en welzijn, in combinatie met de groeiende instroom van schoolverlaters, zullen er waarschijnlijk toe leiden dat schoolverlaters met een diploma zorg en welzijn meer moeite moeten doen om aan werk te komen in vergelijking met de afgelopen jaren. Vooral de lage uitbreidingsvraag staat in schril contrast met de werkgelegenheidsontwikkeling van de afgelopen jaren en de arbeidsmarktprognoses van het ROA van twee jaar geleden. Dit laat duidelijk zien dat bezuinigingen in de zorg- en welzijnssector grote gevolgen hebben voor de baanperspectieven.

\section{Kwaliteit arbeidsmarktinstroom verandert}

Tot 2020 wordt er een aanbod van nieuwe arbeidskrachten verwacht van 1,6 miljoen personen. Dit komt neer op een arbeidsmarktinstroom van 3,1\% gemiddeld per jaar. De samenstelling van de instroom van schoolverlaters zal veranderen: vergeleken met de afgelopen vijf jaar wordt een stijging van de instroom verwacht vanuit mbo niveau 4, hbo en wo. Daarnaast zal de arbeidsmarktinstroom op mbo niveau $2 / 3$ juist dalen ten opzichte van de instroom in de voorbije periode. De instroomprognoses wijzen erop dat het gemiddelde opleidingsniveau van jongeren in Nederland de komende jaren verder zal stijgen.

De instroom van schoolverlaters met een diploma in een economische richting is op de meeste opleidingsniveaus het grootst. Daarnaast zal er in de komende jaren relatief veel arbeidsmarktinstroom zijn vanuit zorgopleidingen in het beroepsonderwijs en op wo-niveau, terwijl daar juist weinig baanopeningen verwacht worden. De verwachte arbeidsmarktinstroom vanuit de technische opleidingen zit duidelijk in de lift vergeleken met de afgelopen jaren. Op hbo- en wo-niveau (maar ook op mbo 4 niveau) wordt 
een grotere jaarlijkse arbeidsmarktinstroom verwacht voor de jaren 2015-2020 dan in de afgelopen vijf jaar.

\section{Redelijke arbeidsmarktperspectieven voor hbo'ers en wo'ers tot 2020}

De zwaarste klappen van de economische crisis lijken achter de rug te zijn, maar de arbeidsmarktperspectieven zijn lang niet voor alle schoolverlaters rooskleurig. Dit heeft te maken met de stijgende arbeidsmarktinstroom van afgestudeerden vanuit de hogere opleidingsniveaus, en het nog steeds grote reservoir aan kortdurig werklozen. Gemiddeld zijn de verwachte perspectieven van schoolverlaters matig voor gediplomeerden uit het mbo, en redelijk voor hbo- en wo-gediplomeerden. De vraag-aanbod verhoudingen op de arbeidsmarkt zijn dus over het algemeen gunstiger naarmate het opleidingsniveau hoger is: op mbo $2 / 3$ niveau worden goed tot zeer goede perspectieven verwacht voor $3 \%$ van de gediplomeerden. Op mbo 4 niveau is dit $19 \%$, en op hbo- en wo-niveau zelfs $25 \%$ en $21 \%$.

De arbeidsmarktperspectieven tot 2020 verschillen sterk tussen de opleidingsrichtingen. De arbeidsmarktsituatie voor schoolverlaters met een diploma in zorg en welzijn zal de komende jaren naar verwachting ongunstig zijn, ongeacht het opleidingsniveau. Stijgende eigen bijdragen voor patiënten, het hogere eigen risico, de neerwaartse druk op de zorgbudgetten vanuit gemeenten en zorgverzekeraars, ingegeven door bezuinigingen van de overheid, leiden ertoe dat de werkgelegenheidsgroei in de zorg stagneert. Binnen deze opleidingsrichting zijn er wel nog redelijke perspectieven geschetst voor wo (dier)geneeskunde en tandheelkunde. Gediplomeerden uit het hbo en wo met een achtergrond in techniek, onderwijs of groen hebben goede arbeidsmarktperspectieven. Op mbo niveau 4 zijn de perspectieven ook goed voor de groene opleidingen. Daarnaast scoren de technische opleidingen op mbo niveaus 2, 3 en 4 redelijk.

\section{Geen arbeidsmarktknelpunten voor werkgevers in de zorg, wel in de techniek en ICT}

Het arbeidsaanbod van recent gediplomeerden met een achtergrond in zorg en welzijn zal relatief groot zijn vergeleken met de vraag, waardoor werkgevers naar verwachting geen problemen zullen ondervinden met het vinden van geschikt personeel. De verwachte knelpunten in de personeelsvoorziening voor werkgevers zijn het grootst in de techniek en voor de ICT-beroepen, de pedagogische beroepen en de managersfuncties. In de ICT-sector zijn de knelpunten vooral gerelateerd aan technologische ontwikkelingen. Nieuwe ontwikkelingen en daarmee gepaard gaande eisen aan kennis en vaardigheden volgen elkaar snel op (ontwikkelingen zoals Cloud computing en Big Data). De knelpunten in de pedagogische beroepen zijn vooral gedreven door de vervangingsbehoefte. Werkgevers in de transport- en logistiekberoepen zullen naar verwachting over het algemeen weinig moeite hebben bij het vervullen van openstaande vacatures. Uitzonderingen hierop zijn de baanopeningen voor beroepen als dekofficieren, piloten, chauffeurs voor taxi's en bestelwagens, en transportplanners en logistiek medewerkers. 
In de commerciële beroepen worden geen knelpunten verwacht in de personeelsvoorziening, omdat de arbeidsmarktinstroom van jongeren voor die beroepen hoog is.

\section{Verschuivingen in de beroepenstructuur 1996-2014}

De beroepenstructuur is aan veranderingen onderhevig. In de jaren 1996-2014 heeft er een stijging plaatsgevonden van het gemiddelde opleidingsniveau van het arbeidsaanbod. Het percentage werkenden dat werkzaam is in een beroep waarvan het modaal opleidingsniveau vmbo was, is afgenomen terwijl het aandeel werkenden met een hboof wo-opleiding in dezelfde periode is gestegen. Het gemiddelde opleidingsniveau is toegenomen met ongeveer 0,8 opleidingsjaar. Deze stijging in het gemiddelde opleidingsniveau blijkt voor $60 \%$ het gevolg van hogere opleidingseisen binnen beroepsgroepen. Voor de overige $40 \%$ is de stijging van het opleidingsniveau het gevolg van meer vraag voor hoogopgeleide beroepen. Groei in beroepen hangt positief samen met stijgende lonen en met het niveau van probleemoplossend vermogen van werkenden in die beroepen. Dit komt mogelijkerwijs doordat complexe technieken voor informatiegebruik en informatieverwerking steeds belangrijker worden.

De top 10 van krimpberoepen bestaat uitsluitend uit beroepen op (v)mbo-niveau. Bij deze beroepen neemt de vraag naar personeel waarschijnlijk af, omdat machines en ICT sommige routinematige taken overgenomen hebben. Denk daarbij aan medewerkers drukkerij en kunstnijverheid, productiemachinebedieners, secretaresses, assemblagemedewerkers en boekhouders (en boekhoudkundig medewerkers). Toch is het niet zo dat alle beroepen op mbo-niveau onder druk staan: in de top 10 van groeiberoepen in de periode 1996-2014 staan namelijk zowel beroepen op hbo-niveau (bijvoorbeeld bedrijfskundigen en organisatieadviseurs) als beroepen op mbo-niveau (bijvoorbeeld sociaal werkers, groeps- en woonbegeleiders). Veranderingen in de opleidingsstructuur binnen beroepen en verschuivingen tussen beroepen gaan geleidelijk. Dit suggereert dat de discussie rond polarisering op de arbeidsmarkt genuanceerd gevoerd moet worden.

Ook de leeftijdsstructuur van de werkenden is veranderd in de periode 1996-2014. In 1996 bestond 31,0\% van de werkenden uit personen jonger dan dertig jaar, in 2014 is dit percentage gedaald tot $24,9 \%$. Het percentage 55 -plussers maakte in diezelfde tijd een substantiële groei door en het ligt in de lijn der verwachting dat dit percentage de komende jaren nog verder toeneemt, onder andere als gevolg van de verhoging van de AOW-leeftijd. Voor vrijwel alle beroepsklassen zien we dat er in 2014 (ten opzichte van 1996) meer 55-plussers werkzaam zijn. Deze trend is vooral sterk in bedrijfseconomische en administratieve beroepen. Voor een aantal beroepsklassen observeren we naast vergrijzing ook ontgroening (lagere instroom van jongeren). Dit is het geval bij de bedrijfseconomische en administratieve beroepen, managers, openbaar bestuur, veiligheid en juridische beroepen, agrarische beroepen, maar bovenal bij de technische beroepen. 
In 2013 telde Nederland ruim 1,5 miljoen arbeidsgehandicapten in de leeftijd van 15 tot 65 jaar. Dit zijn mensen die aangeven dat zij door een langdurige aandoening, ziekte of handicap worden belemmerd bij het uitvoeren of verkrijgen van werk. Het aandeel behorend tot de niet-beroepsbevolking is onder arbeidsgehandicapten met 60,5\% bijna drie keer zo groot als onder de potentiële beroepsbevolking zonder arbeidshandicap (22,6\%). Gemiddeld genomen was in 2013 7,1\% van de werkenden arbeidsgehandicapt. De meeste arbeidsgehandicapten zijn werkzaam in de industrie (inclusief sociale werkvoorzieningen), de landbouw, bosbouw en visserij, en de gezondheids- en welzijnszorg. Ze zijn oververtegenwoordigd in beroepen met een relatief laag opleidingsniveau, zoals landbouwers, bosbouwers en vissers, elementaire beroepen, assemblagemedewerkers en bedieners machines en installaties. Deze beroepen weerspiegelen het lagere opleidingsniveau van arbeidsgehandicapten ten opzichte van niet-arbeidsgehandicapten. Werknemers met een handicap blijken vaker te maken te hebben met onderbenutting, zijn minder breed inzetbaar, hebben een lagere in-role performance (een proxy voor productiviteit) en zijn vaker met ziekteverlof. Bovendien zijn ze over het algemeen minder tevreden met hun baan dan niet-arbeidsgehandicapten. De werkloosheid onder arbeidsgehandicapten in de leeftijd van 15 tot 65 jaar is tijdens de crisisjaren sterker gestegen dan de werkloosheid onder de potentiële beroepsbevolking zonder arbeidshandicap. Daarnaast geldt voor arbeidsgehandicapten die wel een baan hebben voor tenminste 12 uur per week, dat zij een minder goede aansluiting kennen tussen hun opleiding en het werk dat ze verrichten. Arbeidsgehandicapten hebben dus een kwetsbare positie op de Nederlandse arbeidsmarkt.

Om uitval van arbeidsgehandicapten uit het arbeidsproces te voorkomen is het belangrijk ervoor te zorgen dat zij in beroepen/sectoren worden ingezet waarin zij ook op langere termijn een goede kans hebben om aan het werk te blijven. De vier sectoren met de meeste arbeidsgehandicapten - overige industrie, welzijn, landbouw, bosbouw en visserij en voedings- en genotmiddelenindustrie - zullen de komende jaren echter een negatieve of kleine uitbreidingsvraag hebben. Hierdoor zal het voor werkende arbeidsgehandicapten naar verwachting moeilijk zijn om hun baan in deze sectoren te behouden. Ook voor nieuwe instromers met een arbeidshandicap bieden deze sectoren waarschijnlijk weinig kansen op een baan. Het positieve nieuws is dat er een grote werkgelegenheidsgroei wordt verwacht voor de sector verhuur en overige zakelijke dienstverlening: daar werken bovengemiddeld veel arbeidsgehandicapten. 



\section{DOEL EN OPZET VAN DE ARBEIDSMARKTPROGNOSES}

Doel

In dit rapport van het Researchcentrum voor Onderwijs en Arbeidsmarkt (ROA) wordt een overzicht gepresenteerd en besproken van de huidige en toekomstige ontwikkelingen op de Nederlandse arbeidsmarkt tot 2020. Het overzicht heeft als doel inzicht te verschaffen in de actuele arbeidsmarktsituatie en de arbeidsmarktprognoses naar bedrijfssectoren, beroepen en opleidingen. De gegevens over de actuele arbeidsmarktsituatie worden jaarlijks geactualiseerd en opgenomen in het ROA ArbeidsmarktInformatieSysteem (AIS). De prognoses worden elke twee jaar opgesteld en hebben betrekking op een periode van zes jaar. De rapportage vindt plaats in het kader van het door het ROA uitgevoerde Project Onderwijs-Arbeidsmarkt (POA).

De gedachte achter POA is dat gedegen arbeidsmarktinformatie tot een betere allocatie op de arbeidsmarkt leidt. Uit analyses van het ROA Schoolverlatersonderzoek blijkt dat studieloopbaanbegeleiding op school tot betere studiekeuzes leidt.' Bovendien is uit onderzoek gebleken dat de beschikbaarheid van arbeidsmarktinformatie naar opleiding en beroep de transitie van school naar werk voor jongeren verbetert. ${ }^{2}$ De binnen het POA ontwikkelde arbeidsmarktinformatie is relevant voor verschillende doelgroepen. ${ }^{3}$ Een eerste belangrijke doelgroep van de arbeidsmarktinformatie wordt gevormd door jongeren en werkzoekenden die voor de keuze van een (vervolg)opleiding staan. De gegevens stellen hen in staat hun keuze te funderen op de arbeidsmarktperspectieven die de verschillende opleidingen bieden op de middellange termijn. Deze voorlichtingsfunctie wordt in het bijzonder vervuld via verschillende websites van zelfstandige organisaties, zoals UWV (www.werk.nl) en SBB (www.kansopwerk.nl). Ook de verschillende keuzegidsen voor het onderwijs (zie bijv. www.keuzegids.org en www.studiekeuze123.nl) dragen bij aan de verspreiding van de gegevens onder de doelgroep. Deze informatiekanalen maken gebruik van de binnen het POA ontwikkelde arbeids-

1 Borghans, L., Golsteyn, B. \& Stenberg, A. (2013), Does expert advice improve educational choice? Bonn: IZA DP 7649).

2 Saniter, N., \& Siedler, T. (2014), The effects of occupational knowledge: job information centers, educational choices, and labor market outcomes, Bonn: IZA DP 8100. Bardhan, A., Hicks, D. \& Jaffee, D. (2013), How responsive is higher education? The linkages between higher education and the labour market, Applied Economics, 45 (10): 1239-1256.

3 Fouarge, D. (2015), Project Onderwijs-Arbeidsmarkt: Gebruik van arbeidsmarktinformatie en impact,ROA, Maastricht: ROA-TR-2015/4. 
marktinformatie. Het voorliggende rapport is echter vooral bedoeld voor de beleidsontwikkeling van verschillende groepen van beleidsmakers. Wat betreft de beleidsmakers in het onderwijs kunnen de gegevens nuttig zijn voor onderwijsinstellingen en hun financiers, waaronder het Ministerie van Onderwijs, Cultuur en Wetenschap (OCW), het Ministerie van Economische Zaken (EZ), het Ministerie van Binnenlandse Zaken en Koninkrijksrelaties (BZK) en het Ministerie van Sociale Zaken en Werkgelegenheid (SZW), bijvoorbeeld wanneer wordt overwogen nieuwe opleidingen te beginnen of bestaande aan te passen. Een derde doelgroep zijn de werkgevers en hun brancheorganisaties voor wie de prognose-uitkomsten aanwijzingen geven waar zich in de toekomst knelpunten in de personeelsvoorziening zullen voordoen, zodat zij hierop kunnen anticiperen. In de vierde plaats zijn de arbeidsmarktprognoses bedoeld voor het arbeidsvoorzieningsbeleid. Met name voor de begeleiding van werkzoekenden naar de arbeidsmarkt kunnen de prognoses een belangrijke signaalwerking hebben. De gegevens kunnen worden gebruikt door zowel publieke (UWV) als private (uitzend- en re-integratiebureaus) intermediaire organisaties in de arbeidsbemiddeling. Ten slotte zijn de prognoses bedoeld voor het arbeidsmarktbeleid in ruime zin. Daarbij kan gedacht worden aan onder andere het doelgroepenbeleid, het beleid gericht op het vergroten van de arbeidsmarktparticipatie en het arbeidsmarktbeleid ten aanzien van de onderkant van de arbeidsmarkt.

De arbeidsmarktinformatie naar opleiding, beroep en bedrijfssector die samengesteld wordt binnen het POA, dat wil zeggen de verzameling van indicatoren voor de actuele arbeidsmarktsituatie en de middellange prognoses, is geïntegreerd in een online database: het ArbeidsmarktInformatieSysteem (AIS). ${ }^{4}$ Dit databestand bevat veel meer (gedetailleerde) informatie dan in dit rapport wordt gepresenteerd. Op verzoek levert het ROA gedetailleerde informatie uit het AIS op, waardoor verdiepende (wetenschappelijke) studies mogelijk zijn. Het POA is dus een basisvoorziening ten behoeve van het algemene belang voor de hele breedte van het onderwijsveld en het beroepenspectrum van de arbeidsmarkt. Het project geniet internationale bekendheid. Geregeld worden buitenlandse delegaties volledig voorgelicht over het AIS, het prognosemodel en de toepassing en het gebruik ervan. ${ }^{5}$ Recentelijk heeft het ROA het gebruik en het nut van de binnen POA gegenereerde arbeidsmarktinformatie gedocumenteerd. ${ }^{6}$

\section{Prognosemodel}

Bij het maken van de arbeidsmarktprognoses is uitgegaan van een stroomcijfer-aanpak.

Bij deze aanpak worden prognoses gemaakt van de stromen van en naar de arbeids-

4 Zie http://roa.sbe.maastrichtuniversity.nl/?portfolio=poa-project-onderwijs-arbeidsmarkt-2. Een overzicht van de verkrijgbare arbeidsmarktinformatie per bedrijfssector, beroepsgroep en opleidingstype is te vinden in bijlage C. Het AIS is online te benaderen via http://roastatistics.maastrichtuniversity.nl. Van dit systeem is sinds 2015 ook een open access versie beschikbaar met informatie naar sector, beroepsklasse en opleidingscategorie.

5 Zo is het ROA betrokken bij de schattingen van de arbeidsvraag in Europa binnen het CEDEFOP Labour Market Forecast Project. Ook is het ROA momenteel als country expert betrokken bij het in kaart brengen van skills mismatches tussen vraag en aanbod in Europa (project geïnitieerd door CEDEFOP). In 2014 en 2015 is het ROA betrokken geweest bij het adviseren van internationale experten over de haalbaarheid van prognoses studies in landen als Ethiopië en Tanzania (door middel van workshops), alsook Marokko en Libanon binnen het project Partenariat pour les compétences et l'emploi (PACOME).

Zie voetnoot 3. 
markt in een bepaalde toekomstige periode.7 Hierbij worden gegevens gebruikt over feitelijke ontwikkelingen van de werkgelegenheid in het verleden per bedrijfssector, beroep en opleiding (in dit geval ontwikkelingen tussen 1996 en 2014, met als belangrijkste bron cijfers uit de Enquête Beroepsbevolking (EBB) van Centraal Bureau voor de Statistiek (CBS)), prognoses over de toekomstige ontwikkelingen in de werkgelegenheid per bedrijfssector, en eigen (verklarende) econometrische modellen. Deze benadering heeft als voordeel dat de processen in kaart worden gebracht die van belang zijn voor de ontwikkeling van vraag en aanbod op de arbeidsmarkt. Hierbij wordt de arbeidsmarkt in zijn integraliteit in beschouwing genomen. Dit verdient de voorkeur boven een aanpak waarbij deelmarkten worden onderzocht omdat het meer recht doet aan de substitutiemogelijkheden op de arbeidsmarkt. ${ }^{8}$ Zoals het Centraal Planbureau (CPB) het heeft geformuleerd: "Ramingen die niet al te ver vooruitgaan, zoals de ramingen naar sector en opleiding van het ROA [...], zijn zinvol omdat ze de markt van informatie voorzien. Daarnaast houden de ramingen van het ROA wel rekening met de wisselwerking tussen deelmarkten." ${ }^{\prime 9}$

De prognoses worden opgesteld voor in totaal 113 beroepsgroepen en 90 opleidingstypen, gespreid over de volle breedte van de arbeidsmarkt. ${ }^{10}$ Van belang is dat de prognoses, en ook de overige opgenomen arbeidsmarktgegevens, in dit rapport hoofdzakelijk worden gepubliceerd op het niveau van 12 beroepsklassen en 22 opleidingscategorieën." De onderliggende beroepsgroepen en opleidingstypen alsook de gehanteerde indeling voor bedrijfssectoren zijn opgenomen in Bijlage B van dit rapport. Bij de doorrekening van het prognosemodel is uitgegaan van werkenden volgens de internationale ILO-definitie, waarbij alle banen van 1 uur of meer worden meegeteld van personen in de leeftijd 15-74 jaar. ${ }^{12}$ Hier staan wij in hoofdstuk 1 kort bij stil (tekstbox 1.1).

Figuur 1 geeft een schematisch overzicht van het prognosemodel. ${ }^{13}$ Een stroomgrootheid die van belang is voor de vraagzijde van de arbeidsmarkt is de uitbreidingsvraag, die de ontwikkeling weergeeft van de werkgelegenheid in een bepaalde beroepsgroep of een bepaald opleidingstype. Voor de berekening van de uitbreidingsvraag naar beroep en opleiding zijn de macro-economische en sectorale ontwikkelingen

$7 \quad$ Zie bijlage A voor een overzicht van de centrale begrippen bij de arbeidsmarktprognoses.

8 Partiële prognoses kunnen overigens complementair zijn omdat zij voorzien in informatiebehoefte vanuit specifieke markten. Echter, partiële prognoses nemen de wisselwerking tussen deelmarkten niet mee.

9 CPB (2013), Economische analyse van korte en lange termijn knelpunten op de arbeidsmarkt, Den Haag: CPB Notitie, 31 mei 2013.

10 Er wordt in het prognosemodel gerekend met in totaal 114 beroepsgroepen en 90 opleidingstypen. Dit is inclusief de categorieën 'overige beroepen' en 'overige opleidingen' op alle niveaus.

11 Inclusief de categorieën 'overig' gaat het om 13 beroepsklassen en 29 opleidingscategorieën. Vergeleken met de vorige uitgave van dit rapport worden de prognoses voor basisonderwijs, vmbo (inclusief mbo, niveau 1) en havo/vwo alleen besproken in hoofdstuk 1.

12 Ineke Bijlsma, Sander Dijksman, Didier Fouarge, Annemarie Künn-Nelen, Davey Poulissen (2015), Veranderingen in de omvang en samenstelling van de beroepsbevolking als gevolg van de overstap op de ILO-definitie van de beroepsbevolking,Maastricht: ROA-TR-2015/6.

13 De gebruikte methodiek wordt beschreven in: ROA (2015, te verschijnen), Methodiek arbeidsmarktprognoses en -indicatoren 2015-2020, Universiteit Maastricht. Zie bijlage A voor een verdere uitleg van de begrippen en verwijzingen naar de verschillende onderzoeken die door het ROA zijn uitgevoerd in het kader van de modelbouw. 
van groot belang. Hiervoor wordt aangesloten bij de ramingen over de economische groei, de werkgelegenheid en de participatiegraden van het CPB. Voor het samenstellen van de arbeidsmarktprognoses in dit rapport is gebruik gemaakt van ramingen uit het Centraal Economisch Plan 2015. Voor 2015 en 2016 wordt uitgaan van een economische groei van $1,7 \%$ en $1,8 \%$. Voor de jaren daarna wordt uitgegaan van een structurele groei van 1,7\%, waarbij de groei in 2017 nog gedrukt wordt tot 1,5\% door een bezuinigingsbeleid bij de overheidssector en de gezondheids- en welzijnssector. ${ }^{14}$ De in september 2015 verschenen Macro Economische Verkenning 2016 schetst voor de korte termijn weliswaar nog betere perspectieven voor de economische groei, namelijk een groei van $2 \%$ in 2015 en $2,4 \%$ in 2016. ${ }^{15}$ Deze ramingen waren echter nog niet beschikbaar bij het opstarten van het project, en het is bovendien de vraag of deze korte termijn ramingen niet te optimistisch zijn. vorige editie van 'De arbeidsmarkt naar opleiding en beroep' uit 2013 werd nog gerekend met een economische groei van 1,25\% op de middellange termijn (ROA (2013). De arbeidsmarkt naar opleiding en beroep tot 2018, Maastricht: ROA-R-2013/11).

15 Zie bijlage 2, p. 84, in CPB (2015), Macro Economische Verkenning 2016, Den Haag. 
FIGUUR 1 Globale opzet prognosemodel

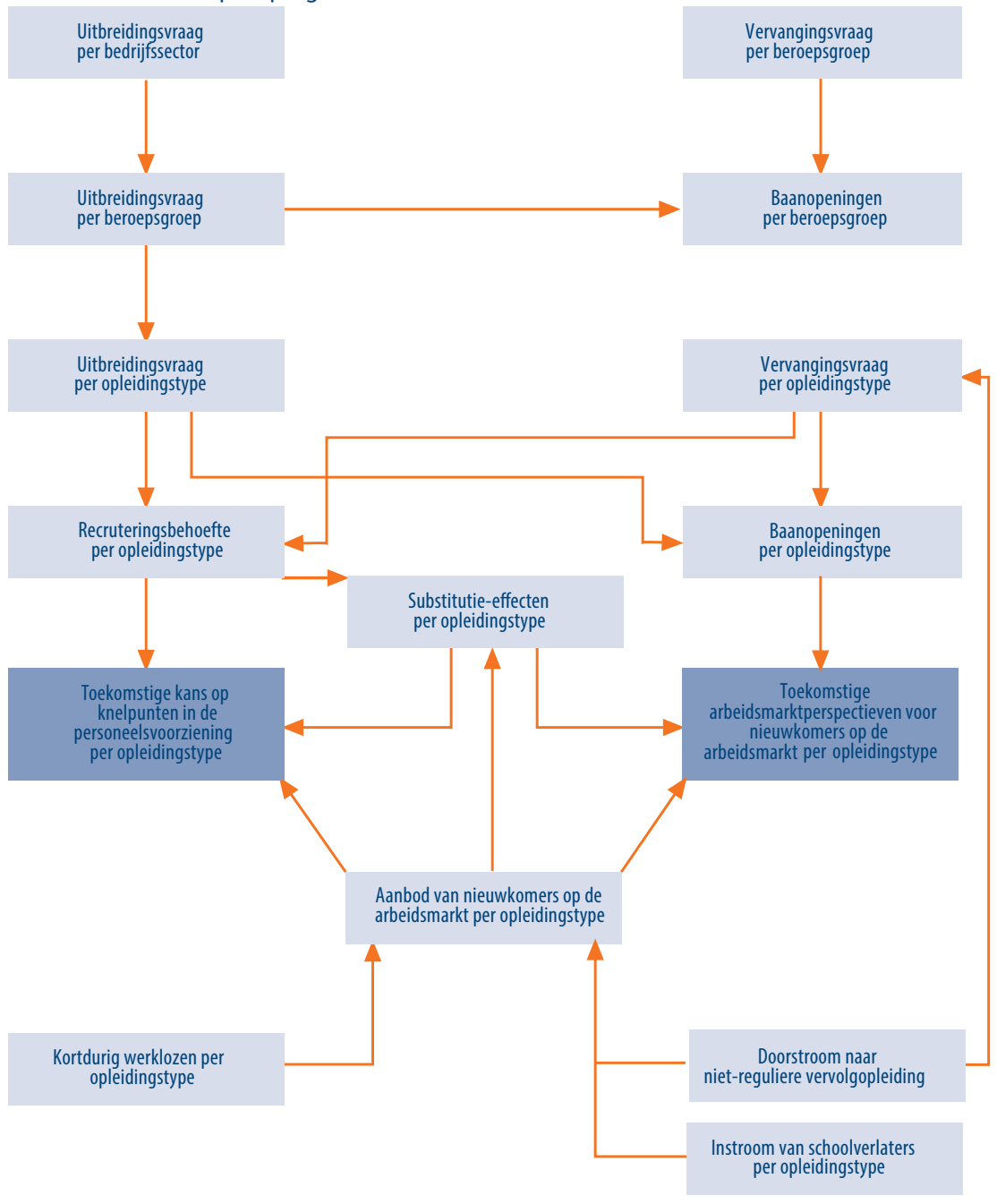

De CPB macro-economische ramingen zijn door Panteia op verzoek van het ROA gedifferentieerd naar 21 bedrijfssectoren. ${ }^{16}$ Voor deze differentiatie naar bedrijfssectoren is gebruik gemaakt van verdeelmodellen (PRISMA-M), waarbij intersectorale relaties worden meegenomen, alsook het onderscheid tussen MKB en grote bedrijven. ${ }^{17}$ Deze prognoses zijn afgestemd op de sectorprognoses van het UWV. ${ }^{18}$ Het betreft hier niet alleen de sectorprognoses voor de werkgelegenheid, maar ook voor de toegevoegde

16 De sectorale afbakening wordt gepresenteerd in bijlage B.

17 T. Kwaak (2006), PRISMA-M: een bedrijfstakkenmodel voor de middellange termijn, Zoetermeer: EIM.

18 http://www.uwv.nl/overuwv/kennis-cijfers-en-onderzoek/arbeidsmarktinformatie/uwv-arbeidsmarktprognose-2015-2016.aspx 
waarde en de investeringen in kapitaal (die gebruikt worden bij de schatting van de uitbreidingsvraag naar beroep), waarbij zoveel mogelijk is uitgegaan van het macroeconomische kader van het CPB.

In aansluiting op de prognoses van de uitbreidingsvraag voor bedrijfssectoren worden door het ROA prognoses gemaakt van de verschuivingen in de beroepenstructuur binnen de onderscheiden bedrijfssectoren. ${ }^{19}$ Hierdoor kan er rekening gehouden worden met het feit dat binnen een bedrijfssector bepaalde beroepsgroepen zich sneller ontwikkelen dan andere. Voorts zijn er in het zogenaamde beroepenmodel van de uitbreidingsvraag, naast de ontwikkeling van de omvang en structuur van de werkgelegenheid, verschillende verklarende variabelen gebruikt (o.a. toegevoegde waarde en investeringen) om de prognoses van de uitbreidingsvraag naar beroep samen te stellen. ${ }^{20}$ Vervolgens wordt bepaald welke implicaties de voorspelde groei van de verschillende beroepsgroepen heeft voor de uitbreidingsvraag per opleidingstype. Hierbij wordt rekening gehouden met het optreden van verschuivingen in de samenstelling van opleidingen binnen beroepsgroepen. ${ }^{21}$ De uitbreidingsvraag per opleidingstype heeft betrekking op het aantal personen met een bepaalde opleidingsachtergrond die werkgevers zouden willen aannemen om te kunnen voorzien in een grotere vraag naar goederen en diensten. De feitelijke ontwikkeling van het aantal werkenden per opleidingstype zal hier doorgaans van afwijken door de interactie met de aanbodzijde van de arbeidsmarkt, en de als gevolg daarvan optredende substitutieprocessen. ${ }^{22}$ Bij de analyse van de werkgelegenheidsontwikkeling naar sector, beroep en opleiding wordt intensief gebruik gemaakt van tijdreeksen van de EBB van CBS (jaren 1996-2014).

Naast uitbreidingsvraag is er op de arbeidsmarkt sprake van vervangingsvraag door al dan niet vervroegde - pensionering, arbeidsongeschiktheid, tijdelijke terugtreding van de arbeidsmarkt, beroepsmobiliteit, e.d. Om de uitstroom te bepalen worden veronderstellingen gemaakt ten aanzien van de participatiegraden in de verschillende leeftijdscohorten. Hiervoor is uitgegaan van de in 2014 uitgebrachte CPB-prognoses van de bruto participatiegraden per leeftijd, geslacht en opleidingsniveau. ${ }^{23}$ Twee jaar geleden is de berekening van de vervangingsvraag naar opleiding verbeterd door rekening te houden met skills-upgrading. In hoofdstuk 4 van dit rapport laten wij zien dat het opleidingsniveau van jongeren in een beroep inderdaad hoger ligt dan dat van ouderen. De systematiek voor de ROA prognoses voor de vervangingsvraag naar beroep is dit jaar verder aangepast zodat de prognoses beter rekening houden met de verschillen in opleidingsniveau van beroepen. Hiervoor worden de nieuwe CPB prognoses, die gedifferentieerd zijn naar opleidingsniveau, expliciet meegenomen bij het schatten van de

19 Dit gebeurt aan de hand van allocatiematrices van beroep naar bedrijfssector voor de periode 1996-2014.

20 F. Cörvers en A. Dupuy (2010), Estimating employment dynamics across occupations and sectors of industry, Journal of Macroeconomics, 32: 17-27.

21 A. Dupuy (2006), Measuring Skill-upgrading in the Dutch Labor Market, ROA-W-2006/3E, Maastricht: ROA.

22 F. Cörvers en H. Heijke (2004), Forecasting the labour market by occupation and education: Some key issues, ROA-W-2004/4, Maastricht: ROA.

23 Euwals, R., M. de Graaf-Zijl \& A. den Ouden (2014). Arbeidsaanbod tot 2060, Den Haag: CPB Achtergronddocument | 3 juli 2014., 
vervangingsvraag naar beroep, waarbij rekening gehouden wordt met het gemiddeld opleidingsniveau in een beroep.

In de prognoses wordt overigens enkel van vervangingsvraag gesproken voor zover het vertrek van een werknemer ook daadwerkelijk leidt tot vraag naar een andere werknemer. Als het vertrek van een arbeidskracht gebruikt wordt om een werkgelegenheidskrimp te effectueren, is er geen sprake van vervangingsvraag. Deze uitstroom is immers niet relevant voor nieuwkomers op de arbeidsmarkt. Dit betekent dus dat niet de volledige arbeidsmarktuitstroom daadwerkelijk leidt tot vervangingsvraag.

De vervangingsvraag wordt voor zowel beroepsgroepen als opleidingstypen berekend. De vervangingsvraag naar beroep kan om verschillende redenen verschillen van de vervangingsvraag naar opleiding. Zo is de mobiliteit tussen beroepsgroepen wel van invloed op de vervangingsvraag per beroepsgroep, maar heeft deze geen effect op de vervangingsvraag per opleidingstype. De mobiliteit tussen beroepsgroepen hebben ten slotte geen directe gevolgen voor de opleidingsstructuur van de werkgelegenheid, hoewel ze hiermee wel kunnen samenvallen. ${ }^{24}$ Daar staat tegenover dat het afronden van een vervolgopleiding gelijk staat aan uitstroom naar een ander opleidingstype. In dat geval is er sprake van een vervangingsvraag bij het opleidingstype waartoe de vooropleiding van deze werkende wordt gerekend. Maar deze vervangingsvraag heeft geen gevolgen voor de beroepenstructuur. 25 Uitstroompatronen naar beroep en opleiding worden geschat aan de hand van de EBB. Bij een toename van de werkgelegenheid vormen de uitbreidingsvraag en de vervangingsvraag tezamen de baanopeningen voor nieuwkomers op de arbeidsmarkt. Bij krimpende werkgelegenheid leidt alleen de vervangingsvraag tot baanopeningen.

Ten opzichte van de vorige prognoses ${ }^{26}$ wordt er nu gewerkt met een nieuwe indeling van beroepen en opleidingen (zie bijlage B). Dit is noodzakelijk vanwege het door CBS uitgevoerde herontwerp van de EBB. Vanaf 2013 wordt in de EBB het beroep van werkenden gecodeerd naar de ISCO classificatie en de opleidingen naar de ISCED classificatie. Samen met CBS heeft ROA een beroepenindeling afgeleid van de ISCO. ${ }^{27}$ Tevens

De mate waarin de vervangingsvraag naar beroep wordt bepaald door beroepenmobiliteit is erg afhankelijk van de beroepsgroep. Gespecialiseerde beroepsgroepen zoals de medisch vakspecialisten laten relatief weinig beroepenmobiliteit zien, en daardoor zal het aandeel van de vervangingsvraag dat aan beroepenmobiliteit te wijten is laag zijn. Er zijn echter andere beroepsgroepen, meestal die waarvoor weinig kwalificatieeisen zijn, waarbij de beroepenmobiliteit een groot deel van de vervangingsvraag behelst. Voorbeelden van dit soort beroepsgroepen zijn kelners en barpersoneel, schoonmakers en vuilnisophalers en dagbladenbezorgers.

25 Indien iemand een nieuwe opleidingskwalificatie behaalt, wordt er vervangingsvraag gecreëerd voor de vooropleiding en neemt de vervangingsvraag voor de vervolgopleiding af. Dit deel van de vervangingsvraag naar opleiding is sinds de invoering van de nieuwe ILO-definitie groter geworden omdat er nu - door het meenemen van de kleine banen van minder dan 12 uur per week - veel meer scholieren worden meegeteld (zie hoofdstuk 1). Scholieren/studenten zijn doorgaans aan het werk voor een relatief klein aantal uren per week en hebben bij hun intrede op de arbeidsmarkt meestal alleen basisonderwijs, vmbo of havo-vwo als opleidingsachtergrond. Zodra zij hun (voorbereidend) onderwijs afgerond hebben, wordt er vervangingsvraag gecreëerd voor de opleidingstypen waar zij vandaan komen.

26 ROA (2013), De arbeidsmarkt naar opleiding en beroep tot 2018, Maastricht: ROA-R-2013/11.

27 ROA (2015), Beroepenindeling ROA-CBS 2014 (BRC 2014), Maastricht: ROA-TR-2015/5. 
heeft ROA een indeling van opleidingen afgeleid van de ISCED, waarbij een onderscheid gemaakt wordt naar niveaus binnen het mbo. ${ }^{28}$ Het herontwerp van de EBB heeft echter trendbreuken voor bepaalde reeksen met zich meegebracht. In het door ons ontwikkelde beroepenmodel voor de uitbreidingsvraag wordt de breuk expliciet gemodelleerd. In de modellen voor de vervangingsvraag is gebruik gemaakt van tijdreeksen 2003-2012, waarbij de uitstroomparameters opgelegd zijn op de cijfers van 2014.

Tegenover de totale vraag staat het verwachte aanbod van nieuwkomers op de arbeidsmarkt. Het aanbod bestaat ten eerste uit de toekomstige arbeidsmarktinstroom van schoolverlaters en de doorstroom naar een ander opleidingstype vanwege het afronden van post-initiële vervolgopleidingen in de prognoseperiode. De tweede component van het arbeidsaanbod bestaat uit het nog boven de markt zwevende aanbod van kortdurig werklozen aan het begin van de prognoseperiode. Hierbij wordt verondersteld dat langdurig werklozen (die langer dan een jaar op zoek zijn naar werk) geen serieuze concurrenten meer vormen voor schoolverlaters. ${ }^{29}$

De instroomprognoses van schoolverlaters op de arbeidsmarkt hebben de Referentieraming 2015 van het Ministerie van Onderwijs, Cultuur en Wetenschap als uitgangspunt. ${ }^{30}$ Deze prognoses hebben betrekking op de verwachte uitstroom uit het initiële onderwijs. Deze prognoses worden door het ROA verbijzonderd naar opleidingstypes en aangevuld met prognoses van de doorstroom naar het post-initiële onderwijs, op basis van gegevens uit de Onderwijsmatrix, de EBB en gegevens uit het ROA Schoolverlatersinformatiesysteem (SIS).

De verwachte vraag- en aanbodstromen per opleidingstype worden met elkaar geconfronteerd om een indicatie te krijgen van de toekomstige arbeidsmarktperspectieven voor nieuwkomers op de arbeidsmarkt. Deze Indicator Toekomstig Arbeidsmarktperspectief (ITA) geeft aan welke vraag-aanbod-discrepantie er per opleidingstype te verwachten is in de komende zes jaar. Als het arbeidsaanbod kleiner is dan de vraag, en de ITA dus kleiner dan of gelijk is aan 1,00, wordt het arbeidsmarktperspectief als goed getypeerd. Als de waarde van de ITA zelfs kleiner dan of gelijk is aan 0,85 , wordt gesproken van een zeer goed arbeidsmarktperspectief. ${ }^{31}$ Daarentegen, als de ITA een waarde heeft tussen de 1,00 en 1,05 - en het aanbodoverschot dus niet veel groter is dan wat als frictie kan worden beschouwd - wordt gesproken van een redelijk arbeidsmarktperspectief. Bij

28 ROA (2015). ROA opleidingsindeling 2015. Maastricht: ROA Technisch Rapport (te verschijnen).

Het CPB concludeert dat de werkloosheidsduur negatief samenhangt met de relevantie van de groep voor het bepalen van het evenwicht op de arbeidsmarkt (M. de Graaf-Zijl, A. van der Horst, D. van Vuuren, 2015, Langdurige werkloosheid. Afwachten en hervormen. CPB Policy Brief 2015/11). UWV hanteert een werkloosheidsduur van 6 maanden bij de afbakening van langdurige werkloosheid. Het is echter belangrijk om op te merken dat de mate waarin het menselijk kapitaal deprecieert door werkloosheid kan verschillen naar studierichting en beroepsachtergrond. https://www.rijksoverheid.nl/documenten/rapporten/2015/08/26/referentieraming-2015 Deze grenzen voor de ITA zijn gebaseerd op een statistische analyse van de spreiding van de arbeidsmarktsituatie van de verschillende opleidingstypen. Zie M. Wieling, A. de Grip en E. Willems (1990), Een systematische kwalitatieve typering van arbeidsmarktinformatie, ROA-W-1990/8, Maastricht: ROA. Zie voor een analyse van de betekenis van de ITA ook A. Dupuy (2009), An evaluation of the forecast of the indicator of the labour market gap, ROA-TR-2009/3, Maastricht: ROA. 
een hogere waarde van de ITA wordt het arbeidsmarktperspectief voor het desbetreffende opleidingstype als matig, of bij een ITA groter dan 1,15, als slecht aangeduid. .2 $^{32}$

Het is belangrijk om stil te staan bij de interpretatie van deze spanningsindicator. Een aanbodoverschot impliceert niet vanzelfsprekend dat de desbetreffende groep werkloos zal worden en een aanbodtekort betekent niet automatisch dat er sprake zal zijn van onvervulde vacatures. Het is immers ook mogelijk dat werkgevers hun eisen aanpassen en mensen aannemen met een andere opleidingsachtergrond dan aanvankelijk gevraagd werd. Schoolverlaters met een opleiding waarvoor het aanbod de vraag overtreft ervaren in een dergelijke situatie een verslechtering van hun positie doordat zij bijvoorbeeld vaker beneden hun niveau of buiten hun richting moeten werken, slechter beloond worden of vaker genoegen moeten nemen met deeltijdwerk, terwijl men liever een voltijdsbetrekking had. ${ }^{33}$ Omgekeerd zal bij een tekortschietend aanbod de positie van schoolverlaters verbeteren. Deze hoeven in dat geval minder vaak genoegen te nemen met een functie op een lager niveau, een lagere beloning e.d. Bij de opleidingen die door opleidingstypen met een aanbodoverschot worden verdrongen, zal het aantal baanopeningen vanwege dit substitutieproces kleiner worden. Daarentegen zal er voor de opleidingen die verwant zijn aan de opleidingen met een tekortschietend aanbod juist sprake zijn van extra baanopeningen. Wanneer er sprake is van knelpunten zullen deze passieve substitutie-effecten derhalve van belang zijn voor de arbeidsmarktperspectieven van de desbetreffende opleidingen. Dit wordt meegenomen bij de berekening van de ITA.

De vraag-aanbod-confrontatie geeft voor elk opleidingstype ook een indicatie van de toekomstige knelpunten in de personeelsvoorziening. Daarbij bepalen de uitbreidings- en vervangingsvraag samen de recruteringsbehoefte per opleidingstype. Bij krimpende werkgelegenheid voor een bepaald opleidingstype wordt deze recruteringsbehoefte op een andere wijze berekend dan het aantal baanopeningen voor nieuwkomers op de arbeidsmarkt. In dat geval bestaat immers vanuit het perspectief van bedrijven de mogelijkheid om de gedwongen uitstroom van het zittende personeel (negatieve uitbreidingsvraag per opleiding) te verminderen. Zeker wanneer bedrijven geconfronteerd worden met een krappe arbeidsmarkt voor een bepaald opleidingstype, mag worden aangenomen dat zij van deze mogelijkheid gebruik zullen maken. De te verwachten spanning in personeelsvoorziening komt tot uiting in de Indicator Toekomstige Knelpunten in de Personeelsvoorziening (ITKP). Omdat er nauwelijks sprake is van negatieve uitbreidingsvraag per opleidingstype zijn de ITA en ITKP tot 2020 vrijwel aan elkaar gelijk. Om die reden wordt de ITKP in dit rapport niet gepresenteerd.

32 ROA evalueert geregeld de kwaliteit van de prognoses. Zie bijvoorbeeld voor de vervangingsvraag R. Montizaan (2009), Evaluatie vervangingsvraagprognoses naar opleiding en beroep, ROA-TR-2009/1, Maastricht: ROA. Uit de evaluatie van voorgaande prognoses blijkt dat voor ruim $40 \%$ van de opleidingstypen de juiste van de vijf mogelijke typeringen werd gegeven. Voor ca. $80 \%$ van de opleidingstypen werd de juiste of een aangrenzende typering voorspeld. Zie A. Dupuy (2009), An evaluation of the forecast of the indicator of the labour market gap, ROA-TR-2009/3, Maastricht: ROA; D. Bertrand-Cloodt (2010), Evaluatie uitbreidingsvraag en indicator toekomstig arbeidsmarktperspectief (ITA) tot 2008, ROA-TR-2010/6, Maastricht: ROA

33 M. Wieling en L. Borghans (2001), Discrepancies between supply and demand and adjustment processes in the labour market, Labour, 15: 33-56. 
De aansluitingsproblematiek tussen onderwijs en arbeidsmarkt verbijzonderd naar de onderscheiden opleidingstypen staat in dit rapport centraal. In aanvulling daarop wordt inzicht gegeven in de implicaties die de vraag-aanbodverhoudingen voor de onderscheiden opleidingstypen hebben voor de knelpunten in de personeelsvoorziening per beroepsgroep. De Indicator Toekomstige Knelpunten in de Personeelsvoorziening naar Beroep (ITKB) reflecteert de verwachte spanning naar beroep. De ITKB geeft de kans weer dat de gewenste personeelssamenstelling naar opleiding binnen beroepsgroepen gerealiseerd kan worden, rekening houdend met de verwachte aanbod per opleiding. Bij het aanbod is dit jaar niet alleen rekening gehouden met het aanbod van kortdurig werklozen en de instroom naar opleiding, maar ook met het verwachte aanbod van scholieren met bijbanen. Dit bleek noodzakelijk i.v.m. de overgang naar de internationale definitie van arbeid. Door deze definitie telt de beroepsbevolking veel kleine banen van jongeren die nog in de instroom zijn verdisconteerd, maar wel een bijbaan hebben als scholier. ${ }^{34}$ Wanneer hier geen rekening mee wordt gehouden, wordt het toekomstig aanbod naar beroep onderschat.

Inzicht in de knelpunten naar beroepsgroep is voor verschillende gebruikers en gebruiksdoelen relevant. In de eerste plaats kan inzicht in de knelpunten naar beroepsgroep van belang zijn voor werkgevers bij hun wervings- en personeelsbeleid. Op de tweede plaats kunnen (langdurig) werklozen of werkenden die op zoek zijn naar een andere werkkring gebruik maken van de informatie in hun oriëntatie naar een nieuwe of andere werkkring. Nauw met dit tweede gebruiksdoel samenhangend zijn de bij- en omscholingsprogramma's die doorgaans gericht zijn op een bepaalde beroepsgroep. Inzicht in de knelpunten naar beroep kan derhalve een leidraad zijn bij het opzetten van dergelijke scholingsprogramma's.

De totale verwachte vraag in de prognoseperiode in het betreffende beroep wordt in dit rapport gerelateerd aan enerzijds de wijze waarop werkgevers de vraag beogen in te vullen qua opleidingsachtergrond van de arbeidskrachten en anderzijds de vraagaanbodverhoudingen voor de voor dat beroep relevante opleidingstypen. Hierdoor wordt een indicatie verkregen van de problemen die werkgevers bij het werven van personeel zullen ondervinden. Wanneer voor een bepaald beroep kennis en vaardigheden vereist zijn die met name aanwezig zijn bij mensen met een opleidingsachtergrond waarvoor grote tekorten worden verwacht, zullen werkgevers veel moeite hebben personeel te vinden dat over de voor dat beroep vereiste kwalificaties beschikt. Wanneer het hier over zeer beroepsspecifieke expertise gaat, zullen de knelpunten extra groot zijn, aangezien er in dat geval weinig alternatieven voorhanden zijn. Wanneer het daarentegen meer algemene competenties betreft, kan de werkgever doorgaans

34 Ineke Bijlsma, Sander Dijksman, Didier Fouarge, Annemarie Künn-Nelen, Davey Poulissen (2015), Veranderingen in de omvang en samenstelling van de beroepsbevolking als gevolg van de overstap op de ILO-definitie van de beroepsbevolking, Maastricht: ROA-TR-2015/6. 
mensen met een andere opleidingsachtergrond aantrekken. De werkgever heeft dan meer substitutiemogelijkheden tussen opleidingen.

In veel gevallen wordt in dit rapport, naast een getalsmatige indicatie, een kwalitatieve typering gegeven van de prognose. Het doel van deze kwalitatieve typeringen is tweeledig. Enerzijds vereenvoudigt de typering de interpretatie van de cijfers. Anderzijds wordt door middel van deze kwalitatieve typeringen rekening gehouden met de onzekerheidsmarges waarmee het opstellen van prognoses gepaard gaat. 



\section{1 \\ DE ARBEIDSMARKT IN VOGELVLUCHT}

\subsection{Inleiding}

In dit hoofdstuk wordt teruggeblikt op recente ontwikkelingen op de arbeidsmarkt en worden de ontwikkelingen op de arbeidsmarkt in hoofdlijnen weergegeven voor de periode tot 2020. Eerst wordt er in paragraaf 1.2 teruggekeken op recente ontwikkelingen in de arbeidsparticipatie, werkloosheid en vacaturegraad in Nederland. In de daarop volgende paragrafen wordt er vervolgens gekeken naar de verwachte macro-economische ontwikkelingen voor de werkgelegenheid, de uitstroom van werkenden op de arbeidsmarkt, het totaal aantal baanopeningen en de instroom van schoolverlaters op de arbeidsmarkt. Zowel de gerealiseerde als de op middellange termijn verwachte werkgelegenheidsontwikkelingen zullen hierbij naar bedrijfssector, beroepsklasse en opleidingsniveau aan bod komen in respectievelijk de paragrafen 1.3, 1.4 en 1.5. De confrontatie tussen de verwachte vraag- en aanbodontwikkelingen op de middellange termijn is bepalend voor de perspectieven van toekomstige schoolverlaters en afgestudeerden op de arbeidsmarkt. Deze arbeidsmarktperspectieven naar opleidingsniveau komen aan bod in paragraaf 1.6. Het hoofdstuk sluit vervolgens af met een conclusie in paragraaf 1.7.

\subsection{Actuele situatie en verwachte ontwikkeling}

\section{Arbeidsparticipatie, werkloosheid en vacatures}

De ontwikkelingen van werkloosheid en arbeidsparticipatie in de afgelopen jaren kunnen het beste begrepen worden door het verloop van de conjunctuur ernaast te leggen. In figuur 1.1 zijn de cijfers voor economische groei en werkloosheid te zien voor 2003 tot en met 2015. De economische crisis in 2008 zorgde voor een stijging in de werkloosheid van 3,7\% in 2008 naar $7,3 \%$ in 2013 . Tevens steeg de jeugdwerkloosheid (15-25 jarigen) in dezelfde periode van $8,6 \%$ naar $13,2 \%$ en de werkloosheid onder ouderen (55-75 jarigen) van 3,8\% naar 6,6\%. Het valt op dat de jeugdwerkloosheid sterker reageert op de economische schommelingen dan de werkloosheid onder de totale beroepsbevolking of onder ouderen. Verder valt te zien dat de jeugdwerkloosheid vanaf 2013 daalt 
naar $11,5 \%$ in de eerste helft van $2015^{35}$, terwijl de ouderenwerkloosheid blijft stijgen naar 7,8\% in de eerste helft van 2015. Een mogelijke verklaring hiervoor is dat de stapsgewijze verhoging van de AOW-leeftijd zorgt voor een groei in de oudere beroepsbevolking, waarbij de kans op werkloosheid toeneemt. ${ }^{36}$ De gemiddelde pensioenleeftijd is van 2003 tot 2014 gestegen van 60,8 naar 64,1 jaar. ${ }^{37}$ De netto arbeidsparticipatie van 55 -plussers is toegenomen van $47 \%$ in 2003 naar $71,8 \%$ in de eerste helft van 2015 , een stijging van maar liefst $28,8 \%$-punt. ${ }^{38}$

Het blijkt dat hoger opgeleiden elk jaar een groter aandeel uit maken van de werkzame 55-plussers dan de lager opgeleiden. Van 2003 tot de eerste helft van 2015 is de arbeidsparticipatie bij de hoger opgeleide 55-plussers gestegen van 70,6\% naar 94,2\% (stijging van 23,6\%-punt) terwijl er bij lager opgeleide 55-plussers sprake was van een stijging van $34,4 \%$ naar $54,7 \%$ (stijging van 20,3\%-punt). Dit wijst erop dat het aandeel hoger opgeleiden onder de werkzame 55-plussers niet alleen groter is dan het aandeel lager opgeleiden, maar ook steeds groter wordt..$^{39}$

In beleidsdiscussies wordt momenteel veel aandacht geschonken aan de positie van middelbaar opgeleiden (zie verder ook hoofdstuk 4). $4^{\circ 0}$ In deze context is het interessant om in te zoomen op de ontwikkeling van werkloosheid bij verschillende leeftijdsgroepen en opleidingsniveaus. Figuur 1.2 presenteert de jeugdwerkloosheid (15 tot 25 jaar), en figuur 1.3 de ouderenwerkloosheid ( 55 tot 75 jaar) naar opleidingsniveau. Bij de jongeren is meteen duidelijk zichtbaar dat de werkloosheidspercentages bij de laagopgeleiden aanmerkelijk hoger zijn dan bij de middelbaar of hoogopgeleiden. Ook is zichtbaar dat vanaf 2013 de werkloosheid van de middelbaar en hoger opgeleide jongeren sterker daalt (respectievelijk van 10,3\% naar 7,8\% en van $7,9 \%$ naar $6,2 \%$ ) dan bij de laagopgeleide jongeren (van 17,4\% naar 16,5\%). Het verschil tussen de laagopgeleiden enerzijds en de middelbaar- en hoogopgeleiden anderzijds lijkt ook bij de jeugdwerkloosheid de afgelopen jaren toe te nemen.

35 In international perspectief is de jeugdwerkloosheid in Nederland laag. In september 2015 was de jeugdwerkloosheid in de EU28 gelijk aan 20,1\%, met ruim twee keer zo hoge werkloosheid in landen als Griekenland en Spanje (Eurostat News Release, 30 October 2015: http://ec.europa.eu/eurostat/documents/2995521/7054219/330102015-AP-EN.pdf/06702a61-81co-45ef-8dof-9ac7fo586908).

36 Rapport De kwantitatieve ontwikkeling van de Nederlandse beroepsbevolking van Economisch Bureau ABN AMRO, Elsevier.

37 Arts, C. H. en F.W.J. Otten (2015), Gemiddelde pensioenleeftijd vanaf 2006 in de lift, Tijdschrift voor Arbeidsvraagstukken, 31(3): 354-360.

38 Bron CBS (Statline), eigen bewerking ROA. De netto arbeidsparticipatie van 65-74 jarigen is overigens gestegen van $5,5 \%$ naar $11,7 \%$ in diezelfde periode.

39 Bron CBS (Statline), eigen bewerking ROA.

40 Zie o.a. de toespraak van minister Asscher (SZW) over de robotisering van arbeid tijdens het SZW congres op 29 september 2014 in Den Haag; Bas ter Weel (2012), Loonongelijkheid in Nederland stijgt, CPB Policy Brief 2012/06 of Wiljan van den Berge, Bas ter Weel (2015), Baanpolarisatie in Nederland, CPB Policy Brief. 
FIGUUR 1.1 Ontwikkeling in werkloosheid en volumemutatie van het bruto binnenlands product (BBP), 2003-2015*

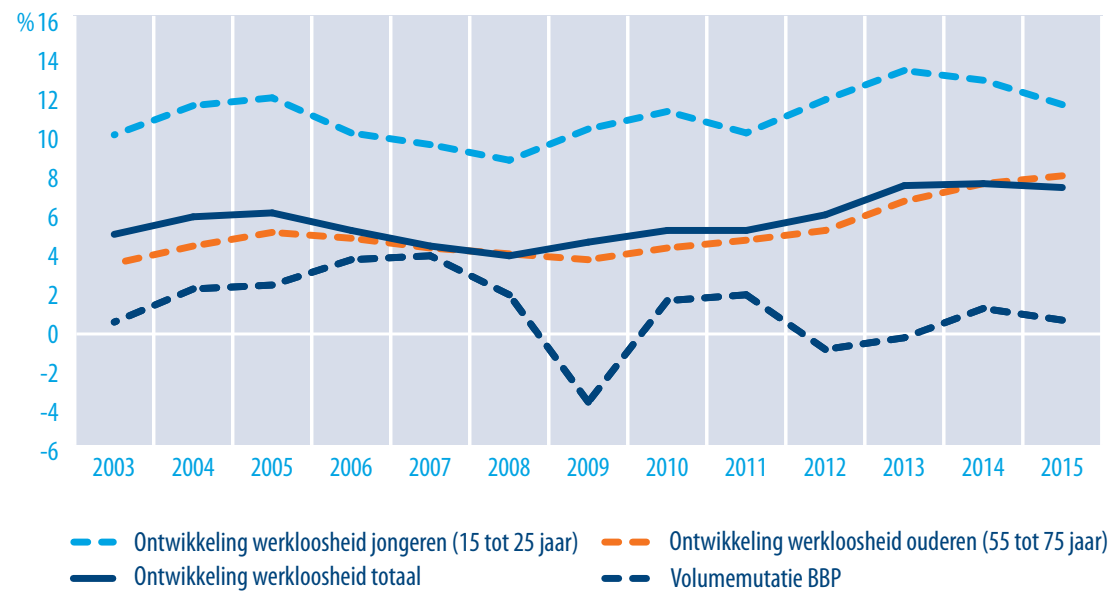

* Meting van 2015 heeft alleen betrekking op de eerste helft van het jaar Bron: CBS (Statline)

Voor de ouderen van 55 tot 75 jaar valt uit de vergelijking tussen figuur 1.2 en figuur 1.3 af te lezen dat het verschil in opleidingsniveau kleiner is dan bij de jeugdwerkloosheid. Bij de jeugdwerkloosheid is er vooral een verschil tussen de laagopgeleiden enerzijds en de middelbaar- en hoogopgeleiden anderzijds. Bij de ouderen is er vooral een verschil tussen de laag- en middelbaar opgeleiden enerzijds en de hoogopgeleiden anderzijds. Deze kloof is ontstaan vanaf 2011 en lijkt met de jaren groter te worden. In 2011 waren de werkloosheidspercentages bij laag-en middelbaar opgeleiden respectievelijk 4,6\% en 4,9\%, terwijl dit bij de hoogopgeleiden slechts $4 \%$ was. In de eerste helft van 2015 is te zien dat bij de laag en middelbaar opgeleide jongeren de werkloosheidspercentages respectievelijk 9,5\% en 9\% waren, en bij de hoger opgeleide jongeren slechts 5,6\%. Het verschil tussen de laag- en middelbaar opgeleiden en de hoogopgeleiden blijkt dus ook bij de ouderenwerkloosheid de afgelopen jaren toe te nemen. Vanuit beleidsoogpunt is dit een punt van zorg.

De werkloosheidscijfers in de figuren 1.2 en 1.3 laten zien dat de werkloosheid onder jongeren hoger is dan onder ouderen, terwijl de langdurige werkloosheid (langer dan één jaar) van 55 -plussers juist hoger is. ${ }^{41}$ Langdurige werkloosheid is hiermee een groter probleem bij ouderen dan bij jongeren. Van de langdurige werklozen is bijna de helft ouder dan 50 jaar, niet doordat oudere werknemers hun baan vaker verliezen, maar doordat de kans op langdurige werkloosheid bijna twee keer zo groot is als gemiddeld

41 De Graaf-Zijl, M., Van Der Horst, A., Van Vuuren, D. (2015), Langdurige werkloosheid: Afwachten en hervormen, CPB Policy Brief, 2015/11. 
wanneer zij hun baan verliezen. Eenmaal werkloos, komen ouderen slechts moeilijk aan werk, ook al hebben zij veel ervaring..$^{42}$

FIGUUR 1.2 Werkloosheid bij jongeren (15-25 jaar), naar opleidingsniveau, 2003-2015*

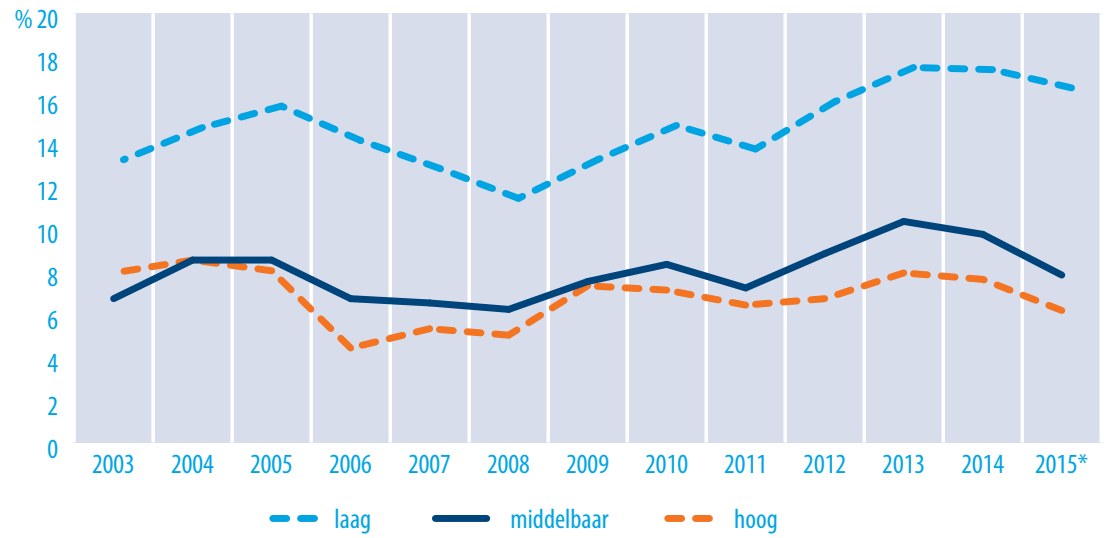

* Meting van 2015 heeft alleen betrekking op de eerste helft van het jaar Bron: CBS (Statline)

FIGUUR 1.3 Werkloosheid bij ouderen (55-75 jaar), naar opleidingsniveau, 2003-2015*

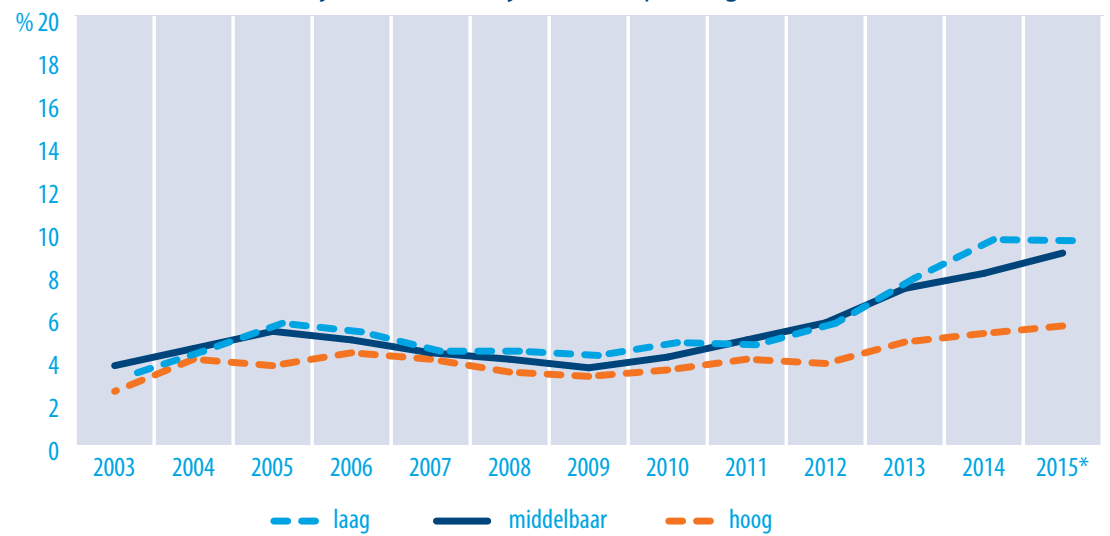

* Meting van 2015 heeft alleen betrekking op de eerste helft van het jaar Bron: CBS (Statline)

42 Didier Fouarge, Raymond Montizaan (2015), Hoe bereid zijn werkgevers om ouderen aan te nemen?, Tijdschrift voor Arbeidsvraagstukken, 31(3): 256-269. 
Met ingang van 2015 hanteert het CBS een andere definitie voor het meten van de omvang van de beroepsbevolking. Waar voorheen gebruik werd gemaakt van een nationale definitie die was vastgesteld door de Centrale Commissie voor de Statistiek (CCS), wordt vanaf 2015 gebruik gemaakt van de definitie van de International Labour Organisation (ILO). Er zijn twee belangrijke redenen om over te stappen op de nieuwe definitie van de beroepsbevolking. In de eerste plaats levert de overstap op de nieuwe definitie cijfers op die in internationaal perspectief beter vergelijkbaar zijn. De IL0-definitie van de beroepsbevolking geldt immers als internationale standaard. Net als CBS nemen wij in de nieuwe definitie van de beroepsbevolking ook de groep 65-74 jarigen mee, een groep personen die gezien de verhoogde AOW-leeftijd in toenemende mate zal participeren op de arbeidsmarkt.

De nieuwe definitie van de beroepsbevolking wordt ook gebruikt door het UWV en het CPB en is tevens gebruikt voor het opstellen van de prognoses in dit rapport, waardoor de in dit rapport gepresenteerde cijfers vergelijkbaar zijn met andere cijfers.

Het belangrijkste verschil tussen de oude en de nieuwe definitie van de beroepsbevolking betreft het urencriterium. De beroepsbevolking bestaat in de oude definitie enkel uit personen die minstens 12 uur per week betaalde arbeid verrichten (werkzame beroepsbevolking) of willen verrichten (werkloze beroepsbevolking). In de nieuwe definitie geldt daarentegen 1 uur als grens. Het ROA bracht zeer recent een technisch rapport uit over de nieuwe definitie van de beroepsbevolking en de veranderingen in de omvang en samenstelling van de beroepsbevolking die optreden als gevolg van de overstap op deze definitie. Enkele conclusies uit dit rapport worden kort in deze tekstbox beschreven.

Allereerst is er gekeken naar de gevolgen van de nieuwe definitie voor de omvang van de beroepsbevolking. Een vergelijking van de beroepsbevolking onder beide definities leert dat de definities een vergelijkbare ontwikkeling in het aantal werkenden, werklozen en het werkloosheidspercentage over de tijd vertonen. Een toenemend aantal werklozen (werkenden) in de oude definitie gaat bijvoorbeeld vrijwel altijd gepaard met een toename in het aantal werklozen (werkenden) volgens de nieuwe definitie. Voor wat betreft de ontwikkeling van deze arbeidsmarktindicatoren leveren beide definities van de beroepsbevolking dus ongeveer hetzelfde beeld op. Dit geldt echter niet voor het absolute aantal werkenden, werklozen en de hoogte van het werkloosheidspercentage. Het aantal werkenden valt veel hoger uit onder de nieuwe definitie, terwijl het aantal werklozen en het werkloosheidspercentage juist lager uitvallen. Al met al resulteert de overgang van de nationale naar de internationale definitie in een toename van de werkzame beroepsbevolking van 7,1 miljoen naar 8,2 miljoen, een lichte afname van het aantal werklozen van 700 duizend naar 660 duizend en een daling in het werkloosheidspercentage van $9 \%$ naar 7,4\% in 2014.

Verder blijkt dat er als gevolg van de overstap op de nieuwe definitie enkele opvallende veranderingen optreden in de samenstelling van de werkzame beroepsbevolking naar leeftijd, geslacht en opleidings-

43 Gebaseerd op: Ineke Bijlsma, Sander Dijksman, Didier Fouarge, Annemarie Künn-Nelen, Davey Poulissen (2015), Veranderingen in de omvang en samenstelling van de beroepsbevolking als gevolg van de overstap op de ILO-definitie van de beroepsbevolking, ROA, Maastricht: ROA-TR-2015/6. 
niveau. Tabel B1.1 geeft voor elk van deze variabelen zowel aan wat de samenstelling van de beroepsbevolking onder de oude als onder de nieuwe definitie is. Aangezien het totaal aantal werkenden toeneemt onder de nieuwe definitie, geeft de tabel ook aan wat de samenstelling van de toegevoegde groep werkenden is. Uit de tabel volgt dat het gemiddelde opleidingsniveau van de werkzame beroepsbevolking daalt onder invloed van de nieuwe definitie en dat het aandeel jongeren, het aandeel ouderen en het aandeel 55-plussers juist toeneemt. Het meest opvallend is de sterke toename in het aandeel jongeren. Waar het aandeel jongeren in de totale groep werkenden onder de oude definitie $21,1 \%$ bedraagt, bestaat maar liefst $60 \%$ van de onder de nieuwe definitie toegevoegde groep werkenden uit jongeren. Hierdoor stijgt het percentage jongeren in totaal van 21,1\% onder de oude definitie naar $25,2 \%$ onder de nieuwe definitie. Nadere analyses lieten zien dat het aandeel jonge vrouwen iets sterker steeg dan het aandeel jonge mannen en dat een groot aandeel van de jongeren die onder de nieuwe definitie worden toegevoegd aan de groep werkenden uit scholieren/studenten bestaat. Het feit dat het aandeel jongeren en daarmee het aandeel scholieren/studenten onder de nieuwe definitie sterk toeneemt, vormt een belangrijke verklaring voor de daling in het gemiddeld opleidingsniveau. De toename in het aandeel 55-plussers is beperkt (van 14,2\% naar 14,6\%) omdat het aandeel 55-plussers vooral toeneemt in beroepsgroepen waar de toename in het aantal werkenden sowieso relatief beperkt is. Tot slot blijkt uit de tabel dat een ruime meerderheid van de groep toegevoegde werkenden uit vrouwen bestaat $(63,1 \%)$. Dit sluit aan bij het relatief hoge aandeel vrouwen dat in deeltijd werkt. Bij een gehanteerd urencriterium van 1 uur in plaats van 12 uur valt dan inderdaad een stijgend aandeel werkenden vrouwen te verwachten.

TABEL B1.1 Samenstelling groep werkenden onder de oude definitie van de beroepsbevolking, onder de groep werkenden die onder de nieuwe definitie wordt toegevoegd aan de oude definitie 'bestaande' groep werkenden en onder het aantal werkenden volgens de nieuwe definitie

\begin{tabular}{|l|r|r|r|}
\hline Gemiddeld opleidingsniveau (GON) & $\begin{array}{r}\text { Oude } \\
\text { definitie }\end{array}$ & $\begin{array}{r}\text { Toegevoegde } \\
\text { werkenden }\end{array}$ & $\begin{array}{r}\text { Nieuwe } \\
\text { definitie }\end{array}$ \\
\hline Percentage jongeren (<30 jaar) & 6,5 jaar & 4,8 jaar & 6,3 jaar \\
\hline Percentage ouderen (55+) & $21,1 \%$ & $60,0 \%$ & $25,2 \%$ \\
\hline Percentage vrouw & $14,2 \%$ & $18,4 \%$ & $14,6 \%$ \\
\hline
\end{tabular}

Bron: ROA (bewerking EBB)

Opmerkingen:

- Zie pagina 10 van het technisch rapport voor meer informatie over de manier waarop het GON is berekend.

- In de operationalisatie van de nieuwe definitie van de beroepsbevolking wordt vaak gebruik gemaakt van een leeftijdsafbakening die afwijkt van de leeftijdsafbakening onder de oude definitie. Verschillen in samenstelling van de beroepsbevolking die optreden als gevolg van verschillen in leeftijdsafbakening zijn in deze tabel niet meegenomen. 
In het technisch rapport is tot slot ook aandacht geschonken aan de effecten voor verschillende beroepsgroepen. In het algemeen bleken beroepsgroepen met bijbanen de sterkste stijging in het aantal werkenden (zowel in absolute als in relatieve termen) te laten zien.

\section{Flexibele arbeidsrelatie}

Over de jaren is het aandeel werknemers met een flexibele arbeidsrelatie in de werkzame beroepsbevolking toegenomen. ${ }^{44}$ Was dit in 2003 nog geen 18\%, in 2015 is dit gestegen tot $27 \%$. Enerzijds kan dit verklaard worden doordat de economische crisis de flexibilisering van de arbeidsmarkt heeft doen versnellen. Met behulp van flexwerkers kunnen bedrijven eenvoudig en snel de bedrijfsomvang naar boven of beneden bijstellen. ${ }^{45}$ Wanneer de ontwikkeling van werknemers met een flexibele arbeidsrelatie wordt gesplitst naar leeftijdsgroepen is te zien dat deze groei voornamelijk te wijten is aan een sterke toename van flexibele werknemers van 15 tot 25 jaar (zie figuur 1.4). Vanaf 2003 tot de eerste helft van 2015 is het aandeel werknemers met een flexibele arbeidsrelatie nauwelijks toegenomen bij de andere leeftijdsgroepen. Het aandeel werknemers met een flexibele arbeidsrelatie onder de 15 tot 25 jarigen is altijd groter geweest dan onder de overige twee leeftijdsgroepen, maar is ook over de jaren heen meer toegenomen. Was het aandeel werknemers met een flexibele arbeidsrelatie bij 15 tot 25 jarigen in 2003 al 44\%, in de eerste helft van 2015 is dit gestegen tot 70\% (toename van 26\%-punt).

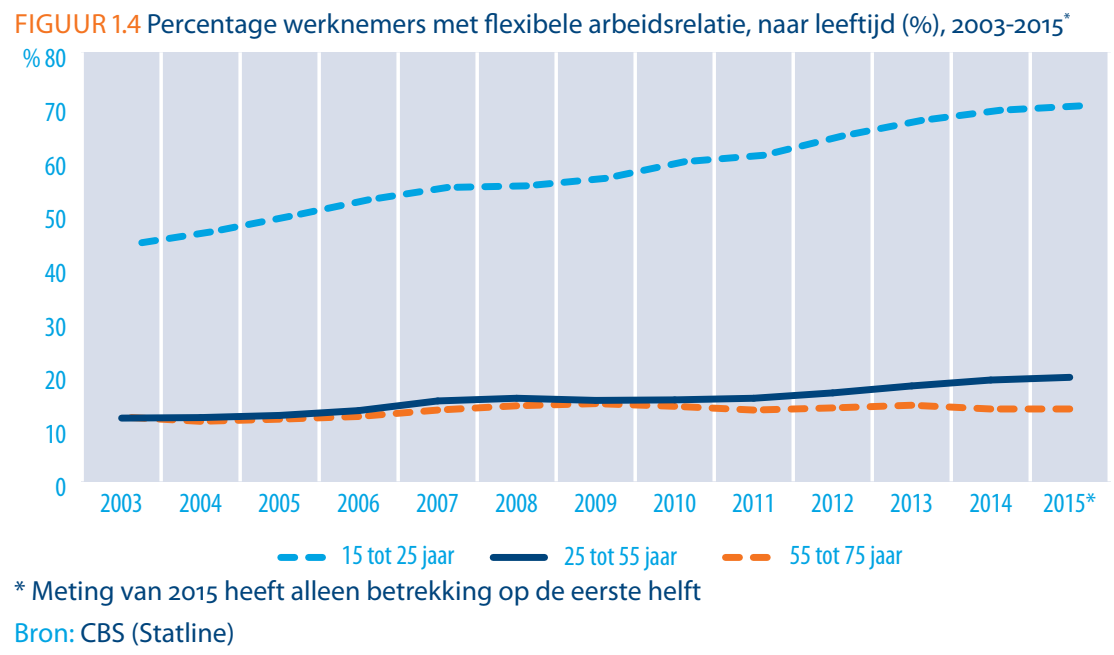

44 Volgens het CBS behoren de volgende groepen tot de werknemers met een flexibele arbeidsrelatie: werknemer met een tijdelijk contract en uitzicht op vast, werknemer met een tijdelijk contract zonder uitzicht op vast, oproep-/inval-/uitzendkracht, werknemer met vast contract, maar geen vaste uren.

45 Chaklova, K., Goudswaard, A., Sanders, J., \& Smits, W. (2015), Dynamiek op de Nederlandse arbeidsmarkt: de focus op flexibilisering. 
Naast het aandeel flexibele werknemers, is het aandeel zelfstandigen weergegeven in figuur 1.5. Hier is duidelijk zichtbaar dat de minste zelfstandigen bij de jongste leeftijdsgroep voorkomen ( 15 tot 25 jaar) en de meeste zelfstandigen bij de oudste leeftijdsgroep ( 55 tot 75 jaar). Het aandeel zelfstandigen is bij de oudste leeftijdsgroep constant gebleven, bij de leeftijdsgroepen $15-25$ en $25-55$ is echter het aantal zelfstandigen sinds 2003 toegenomen (respectievelijk met 2\%-punt en 4\%-punt).

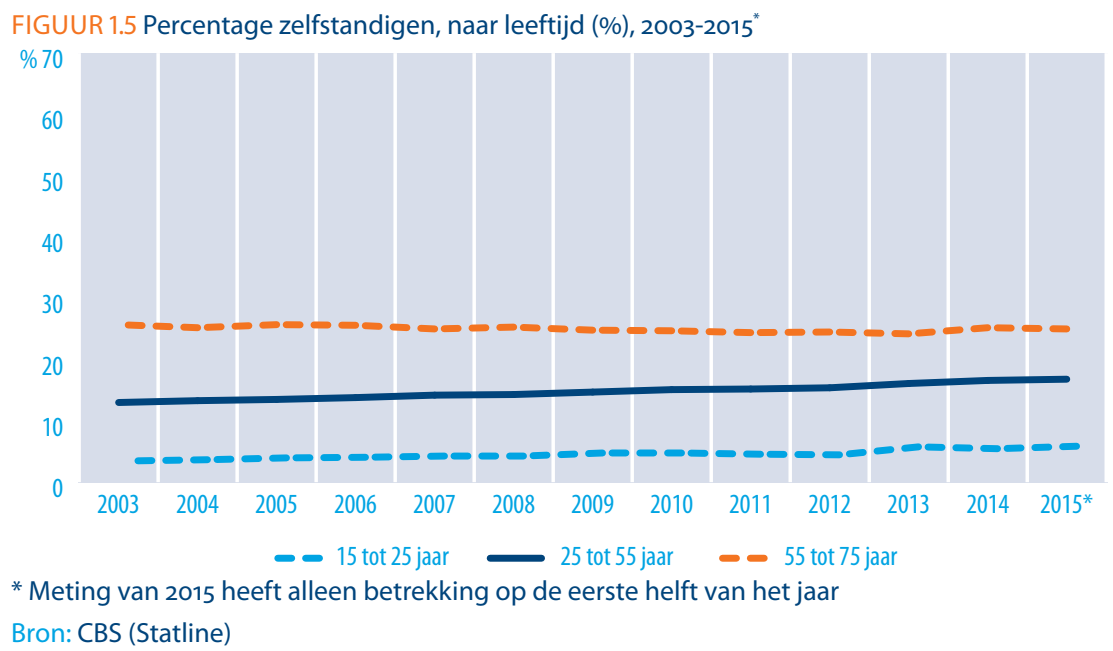

\section{Vacaturegraad en werkloosheid}

Effecten van de conjunctuurcyclus op de arbeidsmarkt kunnen zichtbaar worden gemaakt door te kijken naar de veranderingen van het aantal vacatures en werklozen in het verleden. Bij een aantrekkende economie zullen meer vacatures ontstaan, wat (met enige vertraging) tot een lagere werkloosheid zal leiden. Het verband tussen de vacaturegraad en het werkloosheidspercentage is dus negatief: een stijgend (dalend) aantal vacatures leidt tot minder (meer) werklozen. In figuur 1.6 is de relatie tussen de vacaturegraad (aantal openstaande vacatures) en de werkloosheid in Nederland van 2003 tot 2015 grafisch weergegeven in een zogenaamde 'Beveridge' curve (UnemploymentVacancy curve, oftewel UV-curve). In 2004-2005 is een omslagpunt zichtbaar, waardoor de vacaturegraad verdubbelde van $18 \%$ in 2004 naar $32 \%$ in 2008 , en de werkloosheid afnam. Tussen 2008 en 2010 daalde de vacaturegraad weer terwijl de werkloosheid licht toenam. Vanaf 2011 tot 2013 is te zien dat de werkloosheid verder oploopt en de vacaturegraad op zijn beurt weer afneemt. Van 2013 tot 2015 is de vacaturegraad weer gestegen, en begint de werkloosheid langzaam te dalen. De UV-curve lijkt zich na 2011 meer in zuidoostelijke richting te verschuiven, waarbij er tegelijkertijd meer werkloosheid en minder vacatures zijn dan in de voorgaande jaren. 
FIGUUR 1.6 Relatie tussen vacaturegraad* en werkloosheid in Nederland, 2003-2015 ${ }^{* *}$

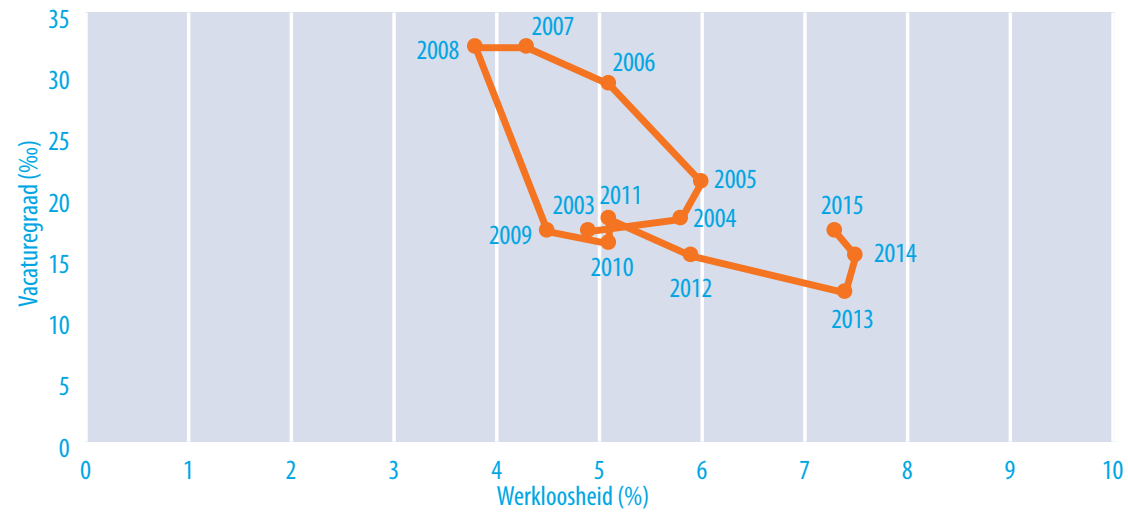

* Betreft de vacaturegraad in het 2de kwartaal van het jaar en de gemiddeld werkloosheid per jaar

** Meting van 2015 heeft alleen betrekking op de eerste helft van het jaar.

Bron: CBS (Statline)

Om meer inzicht te verkrijgen in de relatie tussen de vacaturegraad en de werkloosheid, is deze verhouding nader bekeken voor een aantal Europese landen. In figuur 1.7 is een UV-curve weergegeven voor Nederland, het Verenigd Koninkrijk, België en Duitsland gebaseerd op gegevens van Eurostat voor de jaren 2010-2015. Hierbij zijn duidelijke verschillen in de ontwikkeling van de vacaturegraad en werkloosheid zichtbaar tussen de Europese landen. Voor Nederland is te zien dat van 2011 tot 2013 de vacaturegraad daalde en de werkloosheid opliep, terwijl na 2013 een tegengesteld patroon in lijkt te zetten (zie ook figuur 1.6). Voor Duitsland is een ander patroon zichtbaar, waarbij de werkloosheid daalde en de vacaturegraad opliep van 2010 tot 2015, weliswaar onderbroken met een plotselinge daling van de vacaturegraad in 2013. Het Verenigd Koninkrijk maakt van 2010 tot 2015 een continue beweging van een dalende werkloosheid en een stijgende vacaturegraad. Voor België is een minder rechtlijnige tendens zichtbaar. Van 2010 tot 2011 daalde de werkloosheid en steeg de vacaturegraad licht, en vanaf 2011 tot 2013 nam de werkloosheid weer toe, maar de vacaturegraad bleef desondanks ook stijgen. Vanaf 2013 is een lichte toename in de werkloosheid en een lichte daling in de vacaturegraad zichtbaar waarbij in de eerste helft van 2015 de vacaturegraad weer een flinke groei maakt. Figuur 1.7 laat duidelijk zien dat de ontwikkeling in de relatie tussen vacaturegraad en werkloosheid sterk kan verschillen per land. Deze verschillen in patronen weerspiegelen de mate waarin de verschillende landen geraakt zijn door de kredietcrisis. In Duitsland, bijvoorbeeld, groeide de economie gestaag door en, in tegenstelling tot Nederland, heeft de crisis geen negatieve invloed gehad op de huizenmarkt. 
FIGUUR 1.7 Relatie tussen vacaturegraad* en werkloosheid in Europa, $2010-2015^{* *}$

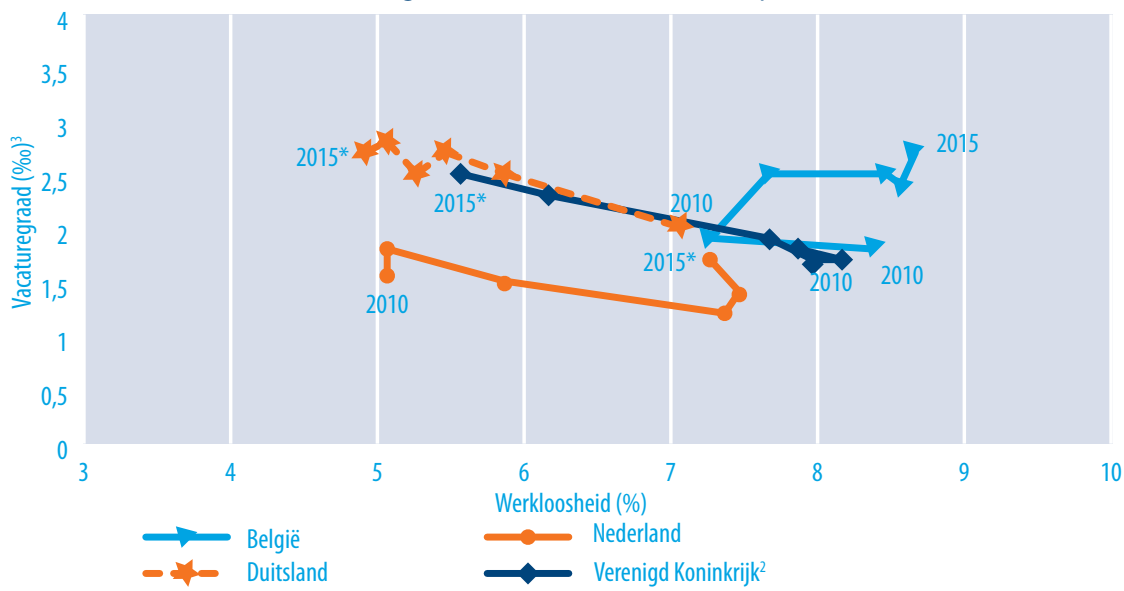

* Betreft de vacaturegraad in het $2^{\text {de }}$ kwartaal van het jaar en de gemiddeld werkloosheid per jaar Voor het Verenigd Koninkrijk is alleen de werkloosheid van het eerste kwartaal beschikbaar De vacaturegraad is niet op de hele breedte van het beroepsveld, aangezien geen cijfers beschikbaar zijn voor de sectoren landbouw en huishoudelijke niet-marktdiensten en producten.

** Meting van 2015 heeft alleen betrekking op de eerste helft van het jaar Bron: Eurostat

\section{Uurloon naar beroep}

De confrontatie tussen vraag en aanbod zal niet alleen resulteren in werkloosheid bij een vraagtekort of een aanbodoverschot. Vraag en aanbod hebben effect op het loonniveau en tegelijkertijd is het loon (en de spreiding daarvan) een belangrijke indicator voor de aantrekkelijkheid van beroepen. ${ }^{46}$ Tabel 1.1 geeft het mediane uurloon per beroepsklasse weer, samen met de reële groei in uurlonen over de periode 2009-2013 en een maatstaf voor spreiding van lonen (of ongelijkheid in beloning binnen beroepsklasse): de verhouding tussen het $90^{\mathrm{e}}$ en het $10^{\mathrm{e}}$ percentiel van de loondistributie. Deze gegevens zijn verkregen door koppeling van informatie over lonen en gewerkte uren uit het Sociaal Statistisch Bestand (SSB) van CBS (SSB-Banen en de Polis-Bestanden) met informatie over het beroep van EBB-respondenten.

46 Fouarge, D., B. Kriechel \& T. Dohmen (2014), Occupational sorting of school graduates: The role of economic preferences, Journal of Economic Behavior \& Organization, 106: 335-351. 
TABEL 1.1 Mediaan uurloon, groei over 2009-2013 en spreiding per beroepsklasse

\begin{tabular}{|l|r|r|r|}
\hline & mediaan uurloon 2013 & $\begin{array}{r}\text { reële groei 2009-2013 } \\
\text { (in procenten per jaar) }\end{array}$ & $\mathrm{p90/p10}$ \\
\hline Managers & 30,5 & 3 & 3,7 \\
\hline ICT-beroepen & 24,2 & -1 & 2,8 \\
\hline Openbaar bestuur, veiligheid en juridische beroepen & 21,0 & -9 & 2,9 \\
\hline Pedagogische beroepen & 20,6 & -3 & 2,4 \\
\hline Zorg- en welzijnsberoepen & 18,4 & -1 & 2,1 \\
\hline Bedrijfseconomische en administratieve beroepen & 18,3 & -3 & 3,0 \\
\hline Creatieve en taalkundige beroepen & 18,1 & -7 & 3,3 \\
\hline Technische beroepen & 17,0 & -5 & 2,8 \\
\hline Commerciële beroepen & 13,2 & 1 & 4,6 \\
\hline Transport- en logistiekberoepen & 13,0 & -5 & 3,8 \\
\hline Agrarische beroepen & 12,1 & -5 & 3,6 \\
\hline Dienstverlenende beroepen & 11,3 & -4 & 3,1 \\
\hline
\end{tabular}

Bron: EBB-SSB (ROA bewerking)

De hoogste uurlonen worden door managers verdiend, gevolgd door ICT-beroepen en door openbaar bestuur, veiligheid en juridische beroepen. De laagste uurlonen worden in dienstverlenende beroepen verdiend, in agrarische beroepen en in transport- en logistiekberoepen.

De spreiding van lonen binnen één beroepsklasse is het laagst voor de zorg-en welzijnsberoepen. ${ }^{47}$ Binnen deze groep verdient het $90^{\circ}$ percentiel ongeveer 2 keer zo veel per uur als het $10^{\mathrm{e}}$ percentiel. De artsen hebben een duidelijk hoger uurloon dan de andere beroepsgroepen binnen deze beroepsklasse (van verzorgenden tot gespecialiseerd verpleegkundigen). Ook in de pedagogische beroepen zijn de loonverschillen betrekkelijk laag, ook al verdienen de sportinstructeurs een duidelijk lager loon dan docenten hoger onderwijs en hoogleraren. De grootste spreiding is bij de commerciële beroepen te zien, waar deze ratio tot 4,6 oploopt. Dit komt omdat deze beroepsklasse zowel kassamedewerkers met een vrij laag uurloon bevat alsook adviseurs marketing en public relations met een hoog uurloon.

Maar ook in andere beroepsklassen kunnen de onderlinge verschillen in uurloon groot zijn. De verschillen zijn ook aanwezig binnen de bedrijfseconomische administratieve beroepen, die reiken van receptionisten en telefonisten tot accountants. Ook binnen de groep managers kunnen de verschillen in uurloon groot zijn, met de managers horeca aan de onderkant van de loonverdeling in deze beroepsklasse en de algemeen directeuren aan de top. Binnen de klasse openbaar bestuur, veiligheid en juridische beroepen verdient het beveiligingspersoneel het minst en juristen en overheidsbestuurders het meest. Binnen de technische beroepen verdienen de bouwarbeiders het minst per uur en de ingenieurs en architecten het meest. Op een vergelijkbare manier vormen de dekofficieren en piloten binnen de transport- en logistiekberoepen een aparte groep,

47 Het spreekt voor zich dat de lonen sterk kunnen verschillen voor de verschillende beroepsgroepen binnen de beroepsklassen. Informatie over het loon naar beroepsgroep is beschikbaar in AIS. 
die aanzienlijk meer per uur verdient dan de andere beroepen (van vuilnisophalers en dagbladenbezorgers, tot buschauffeurs en trambestuurders).

Over de crisisjaren 2009-2013 zijn reële lonen in de meeste beroepsklassen achteruit gegaan, met uitzondering van de commerciële beroepen en de managers, die respectievelijk 1 en 3 procent aan koopkracht hebben gewonnen. Openbaar bestuur, veiligheid en juridische beroepen zijn in reële termen het meest achteruit gegaan, met 9 procent. Hierbij hebben juristen en overheidsbestuurders wel hun loon zien stijgen over de periode 2009-2013, maar de andere groepen niet.

Van de personen die nieuw instromen op de arbeidsmark kan worden verwacht dat het loon gemiddeld genomen lager ligt dan hierboven geschetst. Bij instroom op de arbeidsmarkt in periodes van hoge werkloosheid moet men vaak looneisen inslikken. Bovendien heeft de nieuwe instroom nog geen beroepsspecifieke ervaring opgebouwd. In figuur 1.8 zetten wij de lonen van recent gediplomeerden (uit ROA-SIS) af tegen de lonen van alle werkenden van 15 tot en met 74 jaar (uit EBB-SSB) per beroepsgroep. Het betreft het mediane bruto uurloon. De lonen van recent gediplomeerden zijn weergegeven op de verticale as, en dat van alle werkenden op de horizontale as. In de figuur is elke beroepsgroep aangegeven door een cirkel, waarvan de grootte de omvang van de beroepsgroep weergeeft (aantal werkenden in de EBB). Hierbij wordt een onderscheid gemaakt naar het gemiddeld opleidingsniveau in die beroepen. De doorgetrokken lijn geeft de situatie weer waarin recent gediplomeerden evenveel verdienen als werkenden in vergelijkbare beroepsgroepen. Het is niet verrassend dat de cirkels zich allemaal onder de doorgetrokken lijn bevinden, wat inhoudt dat de mediane lonen van recent afgestudeerden in alle beroepsgroepen gemiddeld genomen lager liggen dan voor werkenden van alle leeftijden in vergelijkbare beroepsgroepen. De gemiddelde leeftijd van alle werkenden ligt immers aanzienlijk hoger, en daarmee de doorgemaakte salarisgroei als gevolg van ervaring, training en leren op het werk. ${ }^{48}$

Gemiddeld genomen verdienen schoolverlaters afgerond 40 procent minder per uur dan werkenden in vergelijkbare beroepsgroepen. Deze discrepantie in het uurloon tussen recent gediplomeerden en alle werkenden in de populatie verschilt echter sterk per beroepsgroep. In het algemeen kan worden geconcludeerd dat het verschil in het loon toeneemt met het gemiddelde opleidingsniveau van een beroepsgroep. Binnen beroepsgroepen met het vmbo als mediaan opleidingsniveau liggen de lonen van recent gediplomeerden het dichtst bij de gemiddelde lonen van alle werkenden, zowel in absolute als in relatieve zin. Vmbo gediplomeerden verdienen, gemiddeld genomen over de verschillende beroepsgroepen, 73 procent van het loon van alle werkenden in de bevolking in dezelfde beroepsgroepen. De verschillen zijn het kleinst voor 'keukenhulpen': zij verdienen anderhalf jaar na afstuderen 86 procent van het gemiddelde inkomen binnen dit beroepssegment. Ook voor wat betreft 'hulpkrachten landbouw' en 'schoonmakers' liggen de lonen van gediplomeerden niet ver van de lonen van alle werkenden. Hun

48 Borghans, L., D. Fouarge, A. de Grip \& J. van Thor (2014), Werken en leren in Nederland, ROA, Maastricht: ROA-R$2014 / 3$. 
perspectieven op doorgroei in de carrière zijn derhalve gering (hier komen we in tabel 1.6 op terug). De loonverschillen tussen afgestudeerden en werkenden worden groter naarmate het een beroepsgroep betreft met een hoger opleidingsniveau. Recent gediplomeerden in middelbare beroepen verdienen 63 procent van wat alle werkenden in de bevolking in deze beroepsgroepen verdienen. De kleinste loonverschillen voor middelbare beroepen vinden we voor buschauffeurs en trambestuurders, de grootste verschillen voor politie en brandweer.

Binnen beroepsgroepen met hoger onderwijs bedraagt het mediane loon slechts iets meer dan de helft van het mediane loon van alle werkenden in die beroepen. Voor de beeldend kunstenaars is dit relatieve verschil het grootst; het mediane uurloon van pas afgestudeerden is slechts een kwart van het mediane uurloon van alle kunstenaars in de Nederlandse bevolking van 15 tot 74 jaar (zie de kleine oranje cirkel die het dichtst tegen de $x$-as ligt). Voor de managers onderwijs is dit loonverschil aanzienlijk kleiner. In de figuur is deze beroepsgroep weergegeven middels de oranje cirkel die het dichtst tegen de diagonale lijn ligt.

De verschillen tussen de lonen van gediplomeerden en de lonen van de beroepsbevolking zijn afhankelijk van verschillende factoren:

1) De (loon-)groeiperspectieven van de beroepsgroep;

2) De concentratie of spreiding van recent afgestudeerden versus alle werkenden in onderliggende beroepen van een beroepsgroep;

3) De leeftijdsopbouw van een beroepsgroep (gerelateerd aan punt 2);

4) De recente tekorten of overschotten aan aanbod voor de beroepsgroepen en daaraan gerelateerde stijging of daling van lonen (voor recent afgestudeerden). 
FIGUUR 1.8 Bruto uurlonen recent gediplomeerden (2014) vergeleken met alle werkenden (2013), naar beroepsgroep

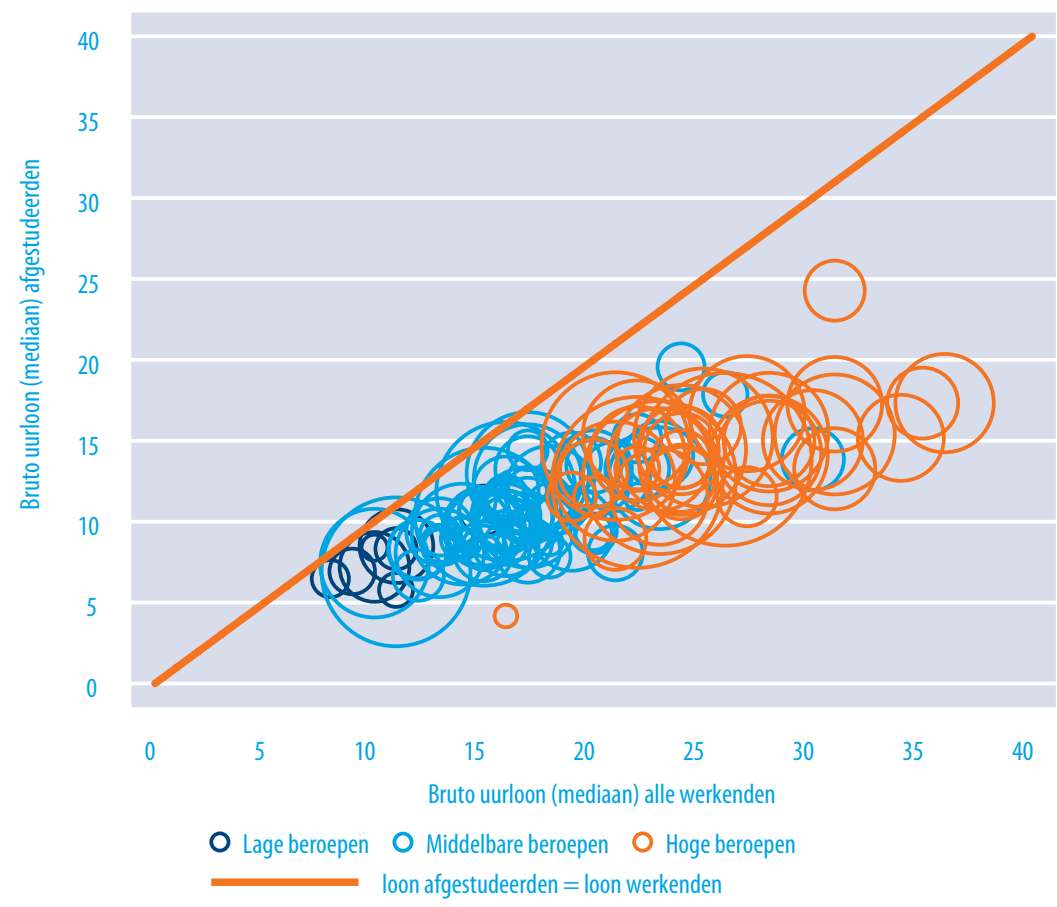

Bron: ROA-SIS, EBB-SSB (ROA bewerking)

\subsection{Verwachtingen voor arbeidsvraag en -aanbod op de middellange termijn}

De arbeidsmarktprognoses van het ROA die in dit rapport worden gepresenteerd hebben betrekking op de periode 2015-2020. Voor het vaststellen van de arbeidsmarktprognoses is het beschikken over ramingen voor de economische groei in de periode waarover prognoses worden opgesteld van groot belang. De door het ROA gehanteerde ramingen voor de groei van Nederlandse economie zijn afkomstig van het Centraal Planbureau (CPB). Voor de groeiramingen op korte termijn wordt aangesloten bij het Centraal Economisch Plan 2015 waarin wordt uitgegaan van een economische groei van $1,7 \%$ in 2015 en $1,8 \%$ in $2016 .{ }^{49}$ Voor de jaren daarna wordt uitgegaan van een structurele groei van 1,7\%, waarbij de groei in 2017 nog gedrukt wordt tot 1,5\% door een bezuinigingsbeleid bij de overheidssector en de gezondheids- en welzijnssector.

Het moge duidelijk zijn dat prognoses altijd met enige onzekerheid gepaard gaan en daardoor enigszins zullen afwijken van uiteindelijke realisaties. Desalniettemin zijn de in dit rapport gepresenteerde prognoses, die gebaseerd zijn op een modelma-

49 Zie bijlage 2, p. 78, in CPB (2015), Centraal Economisch Plan 2015, Den Haag. 
tige aanpak van de uitbreidingsvraag, vervangingsvraag en instroom op de arbeidsmarkt, waardevol voor degenen die keuzes moeten maken voor de toekomst. Hierbij kan onder andere gedacht worden aan scholieren die op het punt staan een studiekeuze te maken, beleidsmakers die hun beleidskoers moeten bepalen en werkgevers die willen inschatten hoe het aanbod van arbeid zich zal ontwikkelen en waar mogelijke tekorten zullen ontstaan. Het nut van de prognoses ligt in het feit dat deze informatie verschaffen betreffende de te verwachten discrepantie tussen vraag en aanbod en daarmee gepaard gaande spanningen op de arbeidsmarkt, waarbij expliciet rekening wordt gehouden met interacties en aanpassingsprocessen tussen deelmarkten.

Op basis van de groeiramingen van de Nederlandse economie en het prognosemodel van het ROA kan een beeld worden geschetst van de te verwachten arbeidsmarktontwikkelingen voor de middellange termijn, in dit geval de periode 2015-2020, waarbij 2015 geldt als eerste prognosejaar en 2020 als laatste prognosejaar..$^{50}$ In tabel 1.2 zijn enkele kerncijfers over de ontwikkeling van de arbeidsmarkt voor de prognoseperiode 2015-2020 weergegeven. Zowel de werkgelegenheidstoename, de arbeidsmarkt inen uitstroom en de baanopeningen zijn in deze tabel weergeven. Alle cijfers hebben betrekking op jaarlijkse groeipercentages ten opzichte van het basisjaar 2014.

TABEL 1.2 Prognoses arbeidsmarktontwikkeling 2015-2020 als gemiddeld jaarlijks percentage van de werkgelegenheid in 2014

\begin{tabular}{|r|r|}
\hline Werkgelegenheidstoename & $2015-2020 \%$ \\
\hline Arbeidsmarktuitstroom & 0,8 \\
\hline Baanopeningen (arbeidsvraag) & 2,9 \\
\hline Arbeidsmarktintroom schoolverlaters $^{1}$ (arbeidsaanbod) & 3,6 \\
\hline
\end{tabular}

${ }^{1}$ Het gaat hierbij om personen die het initiële dag-, deeltijd, niet-reguliere voltijdonderwijs en de beroepsgerichte volwasseneducatie verlaten

Bron: ROA (AIS)

De werkgelegenheidstoename in de periode 2015-2020 wordt afgerond op 0,8\% per jaar geraamd (gemeten in aantal werkenden dat 1 uur of meer werkt per week). Dat wil zeggen dat er in de komende zes jaar per saldo meer werkgelegenheid zal ontstaan dan zal verdwijnen. Als de potentiële beroepsbevolking in deze periode minder snel stijgt dan de werkgelegenheid toeneemt (of zelfs krimpt) zal dit leiden tot daling van de werkloosheid en/of een stijgende netto participatiegraad.

Naast een groei van de totale werkgelegenheid zijn er uiteraard ook personen die de arbeidsmarkt uitstromen, bijvoorbeeld vanwege pensionering, arbeidsongeschiktheid of het verrichten van huishoudelijke werkzaamheden. Tot 2020 wordt jaarlijks een gemiddelde arbeidsmarktuitstroom van 2,9\% per jaar verwacht. In welke mate deze arbeidsmarktuitstroom daadwerkelijk leidt tot vraag naar nieuwe werknemers ter vervanging van de vertrokken werknemers komt tot uitdrukking in de vervangingsvraag. Zoals in

50 ROA (2015), Methodiek arbeidsmarktprognoses en -indicatoren 2015-2020, Maastricht, te verschijnen. 
hoofdstuk 2 zal blijken (zie tabel 2.4) is de geschatte vervangingsvraag afgerond ook gelijk aan 2,9\% op jaarbasis. Dit komt doordat de vervangingsvraag bestaat uit het saldo van de arbeidsmarktuitstroom en de negatieve uitbreidingsvraag en doordat de negatieve uitbreidingsvraag naar opleiding afgerond gelijk is aan o\%. Een deel van de uitstroom en vervangingsvraag tot 2020 ontstaat overigens doordat personen van opleidingsachtergrond veranderen door het volgen van een niveauverhogende of richtingveranderende additionele opleiding naast hun werk. ${ }^{51}$

De totale vraag naar nieuwkomers op de arbeidsmarkt komt tot uitdrukking in het aantal baanopeningen. Baanopeningen kunnen zowel ontstaan als gevolg van een groeiende totale werkgelegenheid als door uitstroom van bestaande werkenden. Het gaat hierbij om de netto werkgelegenheidsgroei en de netto instroom. Dat wil zeggen dat het aantal baanopeningen bepaald wordt door de vervangingsvraag en de positieve uitbreidingsvraag, oftewel de bruto werkgelegenheidsgroei op alleen die segmenten waarop de werkgelegenheidsontwikkeling positief is. Voor de komende jaren wordt het percentage baanopeningen op gemiddeld 3,6\% van het aantal werkenden in het basisjaar geschat.

Tegenover de baanopeningen, die de arbeidsvraag representeren, staat de arbeidsmarktinstroom van schoolverlaters, oftewel het arbeidsaanbod van nieuwkomers. De arbeidsmarktinstroom van schoolverlaters wordt voor de komende zes jaar op gemiddeld 3,1\% per jaar geraamd. Het feit dat het aantal baanopeningen (de arbeidsvraag) de arbeidsmarktinstroom van schoolverlaters (het arbeidsaanbod) overtreft is goed nieuws voor personen die de arbeidsmarkt betreden. In de vorige prognoses (voor de periode 2013-2018) overtrof het arbeidsaanbod nog duidelijk de arbeidsvraag. ${ }^{52}$ Een kanttekening hierbij is dat de arbeidsmarkt nog een groot reservoir heeft aan kortdurig werklozen (ruim 350.000 personen in 2014).

De in tabel 1.2 gepresenteerde cijfers schetsen een globaal beeld van de te verwachten werkgelegenheidsontwikkelingen op de Nederlandse arbeidsmarkt. De arbeidsmarkt bestaat echter uit vele deelmarkten en de ontwikkelingen in deze verschillende deelmarkten kunnen onderling sterk uiteenlopen. Om inzicht te krijgen in de aard en de omvang van deze discrepanties op de verschillende deelmarkten van de arbeidsmarkt zijn de verwachte arbeidsmarktperspectieven voor schoolverlaters en de verwachte knelpunten in de personeelsvoorziening voor werkgevers gedifferentieerd naar beroep en opleiding. Deze perspectieven komen later in dit rapport aan bod.

51 Het gaat hierbij om personen die naast hun werk een erkende opleiding aan een onderwijsinstelling hebben gevolgd. Deze personen worden derhalve ook tot de arbeidsmarktinstroom van hun 'nieuwe', dat wil zeggen meest recent behaalde, opleidingsrichting gerekend. Dit betekent tevens dat de totale instroom van schoolverlaters op de arbeidsmarkt niet alleen bestaat uit schoolverlaters en afgestudeerden die het initiële onderwijs hebben verlaten, maar ook uit werkenden die een post-initiële opleiding succesvol hebben afgesloten.

52 Zie tabel 1.1, p. 8 in ROA (2013), De arbeidsmarkt naar opleiding en beroep tot 2018, ROA, Maastricht: ROA-R2013/11. 


\subsection{Werkgelegenheidsontwikkeling naar bedrijfssector}

Om de werkgelegenheidsontwikkeling van 2015 tot 2020 te kunnen duiden, worden in deze paragraaf de sectorprognoses van de werkgelegenheid vergeleken met de werkgelegenheidstrends van de afgelopen jaren. ${ }^{53}$ Voor elk van de 21 bedrijfssectoren wordt in tabel 1.3 weergegeven hoe de werkgelegenheidsontwikkeling naar bedrijfssector van 1996 tot 2014 is verlopen. Daarnaast wordt de verwachte uitbreidingsvraag voor de periode 2015-2020 weergegeven.

Het gemiddeld aantal werkenden met een baan voor minimaal 1 uur per week over de jaren 2013-2014 was een stevige 8,2 miljoen personen. De grootste sectoren zijn detailhandel, welzijn en specialistische zakelijke dienstverlening. De energiesector is veruit de kleinste sector. Over alle sectoren samen was de feitelijke werkgelegenheidsontwikkeling in de periode 1996-2014 positief (groei van gemiddeld 0,9\% van de werkgelegenheid per jaar). Voor verreweg de meeste sectoren was een groei in werkgelegenheid zichtbaar. De sectoren die het sterkst groeiden in deze periode waren vooral cultuur, sport en recreatie en de zorgsector, maar ook de sector informatie en communicatie en de specialistische zakelijke dienstverlening groeiden relatief sterk. In de industrie is de werkgelegenheid van 1996 tot 2014 afgenomen in alle vier de onderliggende sectoren. Vooral in de metaalindustrie en de voedings- en genotmiddelenindustrie, maar ook in de chemische industrie en in de sector overige industrie is de werkgelegenheid gekrompen. Behalve in de industrie, is ook in de sectoren groothandel en landbouw, bosbouw en visserij de werkgelegenheid afgenomen in de jaren 1996-2014.

De prognoses voor de middellange termijn (van 2015 tot 2020) laten zien dat de werkgelegenheid met gemiddeld o,8\% per jaar zal groeien. De sectoren waarvoor de sterkste groei wordt voorspeld zijn de bouwnijverheid en de specialistische zakelijke dienstverlening. Het dieptepunt van de crisis lijkt hiermee duidelijk voorbij te zijn voor de bouwsector. In de sector groothandel wordt ook een sterke toename in de werkgelegenheid van $1,4 \%$ voorspeld, mogelijk als gevolg van de aantrekkende uitvoer. ${ }^{54}$

Er is overigens ook een aantal sectoren waarvoor de groei van de werkgelegenheid de komende jaren vertraagt. Bij de sector openbaar bestuur en overheidsdiensten verdwijnen er door bezuinigingen banen. De zorgsector en de welzijnssector hebben een flinke werkgelegenheidsgroei meegemaakt in de jaren 1996-2014, maar deze werkgelegenheidsgroei wordt tot 2020 sterk geremd als gevolg van overheidsbezuinigingen. Wel dient opgemerkt te worden dat de werkgelegenheidsprognoses voor beide sectoren vooral negatief uitpakken aan het begin van de prognoseperiode, met een herstel tegen het einde van de periode. In het onderwijs valt ook de verwachte groei van de werkgelegenheid tot 2020 ook lager uit dan in de afgelopen periode, mogelijkerwijs

53 De sectorprognoses dienen als input in het model voor de uitbreidingsvraag naar beroep.

54 Zie ING Kwartaalbericht: Groothandel groeit weer, https://www.ing.nl/nieuws/nieuws_en_persberichten/2015/05/ing_kwartaalbericht_groothandel_groeit_weer.html 
als gevolg van ontgroening. Ook voor de sector sport en recreatie en horeca neemt de groei sterk af.

TABEL 1.3 Ontwikkeling van het aantal werkenden per bedrijfssector 1996-2014, en de uitbreidingsvraag naar bedrijfssector 2015-2020, gemiddelde jaarlijkse groei in beide gevallen als percentage van van de werkgelegenheid in 2014

\begin{tabular}{|c|c|c|c|}
\hline & \multirow[b]{2}{*}{$\begin{array}{r}\text { Aantal } \\
\text { werkenden gem. } \\
2013-2014\end{array}$} & \multicolumn{2}{|c|}{ Werkgelegenheidsontwikkeling } \\
\hline & & $\begin{array}{r}\text { Feitelijk } \\
1996-2014 \\
\%\end{array}$ & $\begin{array}{r}\text { Prognose } \\
2015-2020 \\
\%\end{array}$ \\
\hline Landbouw, bosbouw en visserij & 169.000 & $-0,7$ & $-1,1$ \\
\hline Voedings- en genotmiddelenindustrie & 133.500 & $-1,5$ & 0,0 \\
\hline Chemische industrie & 124.000 & $-1,2$ & $-1,0$ \\
\hline Metaalindustrie & 273.500 & $-1,6$ & 0,2 \\
\hline Overige industrie & 253.500 & $-0,8$ & $-0,9$ \\
\hline Energie & 75.500 & 0,9 & $-0,2$ \\
\hline Bouwnijverheid & 417.500 & 1,0 & 2,2 \\
\hline Detailhandel & 863.000 & 1,2 & 0,8 \\
\hline Groothandel & 401.500 & $-1,2$ & 1,4 \\
\hline Vervoer en opslag & 370.500 & 1,2 & 0,8 \\
\hline Horeca & 330.500 & 2,2 & 0,7 \\
\hline Informatie en communicatie & 262.000 & 2,6 & 1,8 \\
\hline Financiële dienstverlening en onroerend goed & 346.500 & 0,0 & $-0,9$ \\
\hline Specialistische zakelijke dienstverlening & 603.000 & 2,4 & 2,1 \\
\hline Verhuur en overige zakelijke dienstverlening & 418.000 & 0,8 & 1,9 \\
\hline Openbaar bestuur en overheidsdiensten & 503.000 & 0,5 & $-0,1$ \\
\hline Onderwijs & 557.000 & 1,8 & 0,2 \\
\hline Zorg & 583.000 & 2,7 & 0,2 \\
\hline Welzijn & 766.000 & 2,3 & 0,3 \\
\hline Cultuur sport en recreatie & 165.000 & 3,5 & 1,0 \\
\hline Overige dienstverlening, huishoudens en extraterritoriale organisaties & 206.500 & 0,8 & 1,0 \\
\hline Totaal (incl. overig) & 8.240 .500 & 0,9 & 0,8 \\
\hline
\end{tabular}

Bron: ROA (AIS)

De werkgelegenheid zal in de sector landbouw, bosbouw en visserij de komende jaren verder dalen als gevolg van mechanisering en schaalvergroting. De industriesectoren laten een wisselend beeld zien. Voor de chemische industrie wordt een minder sterke krimp verwacht dan in de jaren 1996-2014 en voor de metaalindustrie wordt zelfs een lichte groei verwacht, terwijl de werkgelegenheid van 1996 tot 2014 juist kromp met 1,6\%. Voor de overige industrie wordt echter een verdere krimp verwacht. In de voedings- en genotmiddelenindustrie stabiliseert de werkgelegenheid zich na een periode van krimp. Andere sectoren waarin een krimp in de werkgelegenheid zichtbaar is zijn de sector energie en financiële dienstverlening en onroerend goed. Laatstgenoemde sector is de klappen van de kredietcrisis duidelijk nog niet te boven. 


\subsection{Werkgelegenheidsontwikkeling naar beroepsklasse}

De werkgelegenheidsgroei naar beroep wordt afgeleid uit de werkgelegenheidsgroei in de hiervoor besproken bedrijfssectoren. Om de vertaalslag van bedrijfssectoren naar beroepen te maken, wordt in het ROA-prognosemodel de beroepenstructuur binnen bedrijfssectoren geschat. Bij het schatten van deze beroepenstructuur wordt expliciet rekening gehouden met zowel waargenomen verschuivingen in de beroepenstructuur binnen bedrijfssectoren (d.w.z. intrasectorale verschuivingen) als verschuivingen in de werkgelegenheid tussen bedrijfssectoren (d.w.z. intersectorale verschuivingen) in de jaren 1996-2014. De geschatte beroepenstructuur wordt vervolgens gebruikt om de bedrijfssectorprognoses om te zetten naar prognoses voor de verschillende beroepen.

In tabel 1.4 is het aantal werkenden in de verschillende beroepsklassen weergeven.55 De beroepsklasse bedrijfseconomische en administratieve beroepen vormt qua aantal werkenden de grootste beroepsklasse (18\% van de werkenden). Daarnaast werkt een substantieel deel van het totaal aantal werkenden in de technische beroepen, de zorgen welzijnsberoepen (in beide gevallen 14\%) of in de commerciële beroepen (11\%).

Eveneens gegeven in tabel 1.4 zijn de gemiddelde jaarlijkse groeivoeten van het aantal werkenden in de periode 1996-2014 en de verwachte gemiddelde jaarlijkse werkgelegenheidsgroei in de prognoseperiode (2015-2020). De tabel maakt duidelijk dat tussen 1996 en 2014 de werkgelegenheid in vrijwel alle beroepsklassen toenam. De enige twee uitzonderingen hierop zijn de agrarische beroepen en de technische beroepen. De sterkste werkgelegenheidsgroei vond in de betreffende periode plaats in de creatieve en taalkundige beroepen, de ICT-beroepen en de pedagogische beroepen.

Voor de komende jaren wordt verwacht dat de krimp in de agrarische beroepen zal doorzetten, mede als gevolg van de krimp in de sector landbouw, bosbouw en visserij. In de technische beroepen wordt er groei verwacht na een periode van krimp. Dit komt deels door de gusntige perspectieven in de bouwnijverheid, maar ook deels doordat technici profiteren van de groei in ander sectoren van de economie. Voor alle andere beroepsklassen is er weliswaar sprake van zowel een positieve werkgelegenheidsrealisatie in de afgelopen jaren alsmede een positieve verwachte werkgelegenheidsgroei voor de komende periode, al blijft de verwachte werkgelegenheidsgroei achter bij de gerealiseerde werkgelegenheidsgroei in de periode 1996-2014. Dit verschil is vooral groot bij pedagogische beroepen als gevolg van de afnemende groei in de sector onderwijs door ontgroening en de zorg- en welzijnsberoepen en creatieve en taalkundige beroepen door verwachte bezuinigingen.

55 De 13 onderscheiden beroepsklassen (inclusief de klasse overig) bestaan uit 41 onderliggende beroepssegmenten (inclusief het segment overig), die op hun beurt weer uit 114 beroepsgroepen bestaan (inclusief de groep overig). Zie bijlage B voor een overzicht van de onderliggende beroepssegmenten en -groepen per beroepsklasse. 
TABEL 1.4 Aantal werkenden per beroepsklasse, de feitelijke ontwikkeling van het aantal werkenden per beroepsklasse in de periode 1996-2014 en de verwachte ontwikkeling van het aantal werkenden per beroepsklasse in de periode 2015-2020, gemiddelde jaarlijkse groei als percentage van de werkgelegenheid in 2014

\begin{tabular}{|c|c|c|c|}
\hline & & Werkgelegenhe & ling \\
\hline & $\begin{array}{r}\text { Aantal werkenden } \\
\text { gem. 2013-2014 }\end{array}$ & $\begin{array}{r}\text { Feitelijk } \\
1996-2014 \\
\%\end{array}$ & $\begin{array}{r}\text { Prognose } \\
2015-2020 \\
\%\end{array}$ \\
\hline Pedagogische beroepen & 567.000 & 2,2 & 0,2 \\
\hline Creatieve en taalkundige beroepen & 202.500 & 2,2 & 0,9 \\
\hline Commerciële beroepen & 940.000 & 0,6 & 0,7 \\
\hline Bedrijfseconomische en administratieve beroepen & 1.459 .500 & 1,2 & 1,0 \\
\hline Managers & 538.000 & 1,2 & 1,0 \\
\hline Openbaar bestuur, veiligheid en juridische beroepen & 290.000 & 1,8 & 0,8 \\
\hline Technische beroepen & 1.180 .000 & $-0,7$ & 1,2 \\
\hline ICT-beroepen & 294.000 & 2,2 & 1,2 \\
\hline Agrarische beroepen & 192.500 & $-1,6$ & $-0,6$ \\
\hline Zorg-en welzijnsberoepen & 1.126 .500 & 1,9 & 0,2 \\
\hline Dienstverlenende beroepen & 739.500 & 1,3 & 1,1 \\
\hline Transport- en logistiekberoepen & 567.000 & 1,5 & 0,9 \\
\hline Totaal (incl. overig) & 8.240 .500 & 0,9 & 0,8 \\
\hline
\end{tabular}

Bron: ROA (AIS)

\subsection{Werkgelegenheidsontwikkeling naar opleidingsniveau}

Waar in de vorige paragraaf de werkgelegenheidsontwikkelingen naar beroepsklasse centraal stond, staat in deze paragraaf de werkgelegenheidsontwikkeling naar de hoogst behaalde opleidingsniveau centraal (tabel 1.5)..$^{56}$ De groep werkenden met basisonderwijs, vmbo of havo/vwo bevat de meeste personen (31\%), maar hier zitten ook veel personen tussen met een kleine baan die nog bezig zijn met hun (vervolg) opleiding ( $16 \%$ is scholier). De een na grootste groep werkenden bestaat uit hbo'ers ( $21 \%$ van alle werkenden).

Het aantal werkenden met een laagopleidingsniveau (niet hoger dan havo/vwo) is in de afgelopen periode gekrompen met gemiddeld $0,6 \%$ gemiddeld per jaar. De verwachte positieve werkgelegenheidsgroei tot 2020 is verassend, maar ook wel te verklaren: hoewel er sprake is van krimp in veel laag- en middelbaar opgeleide beroepen (zie hoofdstuk 4), zijn er ook laag- en middelbaar opgeleide beroepen die groeien. Dit geldt bijvoorbeeld voor laders, lossers en vakkenvullers en hulpkrachten bouw en industrie. Bovendien zijn laagopgeleiden soms ook werkzaam in andere beroepen dan lage

56 In dit rapport worden basisonderwijs, vmbo en mbo niveau 1 als hoogst behaalde opleiding in één categorie samengevoegd omdat deze opleidingen geen startkwalificatie bieden. 
beroepen. De groei in die beroepen draagt ook bij aan de groei in de vraag naar laagopgeleiden, omdat de vraag naar opleidingen afgeleid is van de vraag naar beroepen.

Uit de werkgelegenheidsontwikkeling voor de periode 1996-2014 blijkt dat de eerder besproken werkgelegenheidsontwikkelingen in de bedrijfssectoren en beroepen vooral hebben geleid tot een groei van het aantal banen voor hoger opgeleiden (hbo of wo). De verwachting voor de periode tot 2020 is dat deze groei zal doorzetten, maar in een lager tempo. Dit betekent overigens niet dat er een einde komt aan de skill-upgrading van de beroepsbevolking (zie ook hoofdstuk 4). In een andere publicatie laten wij zien dat de groei in het gemiddelde opleidingsniveau van de Nederlandse beroepsbevolking structureel stijgt, maar dat het tempo daarvan in de periode 1981-2010 langzaam afneemt. ${ }^{57}$

TABEL 1.5 Aantal werkenden per opleidingsniveau, de feitelijke ontwikkeling van het aantal werkenden per opleidingsniveau in de periode 1996-2014 en de verwachte ontwikkeling van het aantal werkenden per opleidingsniveau in de periode 2015-2020, gemiddelde jaarlijkse groei als percentage van de werkgelegenheid in 2014

\begin{tabular}{|l|r|r|r|}
\hline & & Werkgelegenheidsontwikkeling \\
& Aantal werkenden \\
gem. 2011-2012 & $\begin{array}{r}\text { Feitelijk } \\
1996-2014\end{array}$ & $\begin{array}{r}\text { Prognose } \\
2015-2020 \\
\%\end{array}$ \\
\hline basisonderwijs, vmbo, havo/vwo & 2.526 .000 & $-0,6$ & 0,9 \\
\hline mbo 2/3 & 1.472 .000 & $-0,8$ & 0,8 \\
\hline mbo 4 & 1.298 .000 & 2,0 & 0,8 \\
\hline hbo & 1.753 .500 & 2,6 & 0,7 \\
\hline wo & 1.080 .000 & 2,4 & 0,8 \\
\hline Totaal (incl. overig) & & & 0,8 \\
\hline
\end{tabular}

Bron: ROA (AIS)

\subsection{Toekomstige arbeidsmarktperspectieven naar opleidingsniveau}

In deze paragraaf komen de toekomstige arbeidsmarktperspectieven gedifferentieerd naar opleidingsniveau aan bod. Deze toekomstige arbeidsmarktperspectieven zijn het resultaat van de confrontatie tussen vraag naar en aanbod van arbeid. De totale vraag naar personen met een bepaald opleidingsniveau bestaat hierbij uit de som van de uitbreidingsvraag, de vervangingsvraag en de additionele vraag die ontstaat als gevolg van substitutie-effecten tussen opleidingstypes. ${ }^{58}$ De instroom van schoolverlaters en het aantal kortdurig werklozen op de arbeidsmarkt vormen samen het totale aanbod

57 I. Bijlsma, S. Dijksman, D. Fouarge, A. Künn-Nelen (2015), Winnaars en verliezers 1996-2012, Tijdschrift voor Arbeidsvraagstukken, 31(2): 106-123.

58 Deze substitutievraag bestaat uit de additionele vraag naar een bepaald type opleiding als gevolg van aanbodtekorten of-overschotten bij (vanuit arbeidsmarktoogpunt) aanverwante opleidingen. Dit betekent dat de substitutievraag dus zowel positief als negatief kan zijn. 
van personen met een bepaald opleidingsniveau..$^{59}$ Indien de verwachte vraag naar personen met een bepaald opleidingsniveau wordt vergeleken met de arbeidsmarktinstroom van schoolverlaters en het aantal kortdurig werklozen, kan een indicatie worden verkregen van de toekomstige arbeidsmarktperspectieven per opleidingsniveau. Deze indicatie wordt weergegeven met de Indicator Toekomstig Arbeidsmarktperspectief (ITA); een deling van het verwachte aanbod door de verwachte vraag tot 2020. De ITA geeft de ex ante spanning weer in de verwachte ontwikkeling tussen vraag en aanbod van schoolverlaters. Bij een ITA die gelijk is aan 1 is de arbeidsvraag gelijk aan het arbeidsaanbod: er is in dat geval dus sprake van een ex ante evenwicht tussen vraag en aanbod. Hoe groter de ITA, des te groter het arbeidsaanbod ten opzichte van de vraag, en des te slechter daardoor het perspectief van schoolverlaters. Naarmate de ITA lager is, is het perspectief beter. Tabel 1.6 geeft voor elk opleidingsniveau de bijbehorende ITA samen met enkele andere indicatoren, waaronder enkele componenten van de ITA.

Zoals uit tabel 1.6 blijkt is de vervangingsvraag voor alle opleidingsniveaus groter dan de uitbreidingsvraag. Aangezien het aantal baanopeningen wordt bepaald door de optelsom van de vervangingsvraag en de positieve uitbreidingsvraag wordt het aantal baanopeningen voor alle opleidingsniveaus de komende jaren vooral bepaald door de vervangingsvraag, en in mindere mate door de uitbreidingsvraag. De vervangingsvraag ontstaat bijvoorbeeld doordat zittend personeel vertrekt door pensionering, arbeidsongeschiktheid, zwangerschap of doorstroom op de arbeidsmarkt. In vergelijking met de vorige prognoses speelt de uitbreidingsvraag desondanks een relatief grotere rol voor het aantal baanopeningen. In de vorige prognoses kwam de uitbreidingsvraag voor vrijwel alle opleidingsniveaus immers op nul uit, terwijl de uitbreidingsvraag voor de huidige prognoses voor alle opleidingsniveaus positief is. ${ }^{60}$ Aangezien de gemiddelde jaarlijkse arbeidsmarktinstroom $(3,1 \%)$ nog steeds relatief hoog is, resulteert dit in weinig gevallen tot goede arbeidsmarktperspectieven. ${ }^{61}$ Toch zijn er tussen opleidingtypes wel degelijk grote verschillen (zie hoofdstuk 3).

Aan de ITA is te zien dat de arbeidsmarktperspectieven relatief goed zijn voor de personen met een hoogstbehaalde opleiding op havo/vwo niveau of lager. Voor $87 \%$ van hen zijn de perspectieven goed..$^{62}$ Dit komt door een relatie lage arbeidsmarktinstroom in verhouding tot de baanopeningen. ${ }^{63}$ De arbeidsmarktperspectieven voor dit opleidingsniveau op basis van de ITA dienen echter voorzichtig geïnterpreteerd te worden. In de eerste plaats wordt de vraag voor een belangrijk deel bepaald door de vraag naar

59 Onder kortdurig werklozen worden in dit rapport personen verstaan die minder dan één jaar werkloos zijn.

60 Zie tabel 1.5, p. 14 in ROA (2013), De arbeidsmarkt naar opleiding en beroep tot 2018, ROA-R-2013/11, Maastricht University.

61 Daarnaast telt ook kortdurig werkloosheid (ruim 4\%) mee bij de bepaling van het aanbod naar opleiding op de arbeidsmarkt.

62 Wellicht dat het lage wettelijk minimumjeugdloon in verhouding tot het wettelijk minimumloon ertoe bijdraagt dat de positie van jongeren op de arbeidsmarkt positief afsteekt ten opzichte van andere Europese landen. Het CPB waarschuwt dat een verhoging van het wettelijk minimumjeugdloon deze gunstige positie zou kunnen aantasten. Zie D. van Vuuren en N. Bosch (2012), Het Wettelijk minimumjeugdloon en de arbeidsmarkt voor jongeren, Den Haag: 21 december 2012.

63 De lage instroom is toe te schrijven aan het preventiebeleid voor voortijdig schoolverlatn (zie De Witte, K. et. al. (2014), Voortijdig schoolverlaten, Rapportage van TIER/Platform 31). 
werkenden in kleine banen. Onder werkenden met als hoogst behaalde opleiding havo/ vwo is ruim $16 \%$ scholier met een kleine baan die nauwelijks genoeg inkomen oplevert voor economische zelfstandigheid. In de tweede plaats kunnen laagopgeleiden bij verslechterende arbeidsmarktomstandigheden gemakkelijk worden verdrongen door schoolverlaters van hogere opleidingsniveaus waardoor de arbeidsmarktperspectieven minder gunstig kunnen uitpakken dan ex-ante geprognosticeerd. In de derde plaats zijn de arbeidsmarktperspectieven op de langere termijn gering voor deze groep: zij zijn vaker aangewezen op flexibele banen en maken weinig kans op doorstroom naar hogere functies. Om dit te illustreren presenteert tabel 1.6 een indicator voor loopbaanperspectieven die afgeleid is van de loongroei naar opleidingniveau tussen de leeftijd 25 en $45 .{ }^{64}$ De loopbaanperspectieven voor laagopgeleiden zijn matig, en slecht voor mbo 2/3. Een belangrijke conclusie uit tabel 1.6 is dat de arbeidsmarktperspectieven beter worden naarmate het opleidingsniveau hoger is. Voor hbo en wo gediplomeerden zijn de perspectieven beter (redelijk, met dus een klein 'aanbod overschot' van maximaal $5 \%$ ) dan voor mbo'ers (matige perspectieven). Binnen het mbo wordt op niveau 4 voor $19 \%$ van de schoolverlaters een goed tot zeer goed arbeidsmarktperspectief verwacht, terwijl het voor schoolverlaters van niveau $2 / 3$ slechts $3 \%$ betreft. Voor een kwart van de hbo-afgestudeerden en voor $21 \%$ van de afgestudeerde met een wo-achtergrond worden goede arbeidsmarktperspectieven volgens de ITA verwacht. Bovendien zijn de loopbaanperspectieven of hbo en wo niveau ook goed tot zeer goed.

TABEL 1.6 Arbeidsmarktperspectief naar opleidingsniveau tot 2020

\begin{tabular}{|c|c|c|c|c|c|c|c|}
\hline & $\begin{array}{r}\text { Uitbreidings- } \\
\text { vraag } \%\end{array}$ & $\begin{array}{r}\text { Vervangings- } \\
\text { vraag } \%\end{array}$ & $\begin{array}{r}\text { Instroom } \\
\%\end{array}$ & ITA & $\begin{array}{r}\text { Typering } \\
\text { ITA }\end{array}$ & $\begin{array}{r}\text { Goed } \\
\text { perspectief } \\
\%\end{array}$ & $\begin{array}{l}\text { Loopbaan- } \\
\text { perspectief }\end{array}$ \\
\hline basisonderwijs, vmbo, havo/vwo & 0,9 & 3,8 & 2,0 & 0,92 & goed & 87 & matig \\
\hline $\mathrm{mbo} 2 / 3$ & 0,8 & 2,8 & 4,2 & 1,08 & matig & 3 & slecht \\
\hline mbo 4 & 0,8 & 2,0 & 3,6 & 1,09 & matig & 19 & redelijk \\
\hline hbo & 0,7 & 2,3 & 3,3 & 1,05 & redelijk & 25 & goed \\
\hline wo & 0,8 & 2,5 & 3,2 & 1,02 & redelijk & 21 & zeer goed \\
\hline Totaal & 0,8 & 2,9 & 3,1 & 1,01 & redelijk & 26 & \\
\hline
\end{tabular}

Bron: ROA (AIS)

64 De indicator voor loopbaanperspectief is per opleiding berekend aan de hand van het verschil in bruto uurloon van werkenden in de leeftijdsgroep 20-29 jaar en 40-49 jaar (zie voor een argumentatie Fouarge, D., Kriechel, B., \& Dohmen, T. (2014), Occupational sorting of school graduates: The role of economic preferences. Journal of Economic Behavior \& Organization, 106, 335-351). Deze gegevens zijn verkregen door koppeling van informatie over lonen en gewerkte uren uit het Sociaal Statistisch Bestand (SSB) van CBS (SSB-Banen en de Polis-Bestanden) met informatie over het opleidingstype van EBB-respondenten. Deze loongroei is vervolgens ingedeeld in kwintielen. De indicator voor loopbaanperspectief neemt de volgende waarde voor de 5 oplopende kwintielen: slecht, matig, redelijk, goed, zeer goed. Dat de loopbaanperspectieven voor bo/ vmbo/havo/vwo gusntiger zijn dan voor mbo $2 / 3$ komt overigens doordat havo/vwo'ers in de leeftijd $40-49$ jaar toch nog een behoorlijk uurloon verdienen (in derde kwintiel). Maar het gaat hier om een kleine en mogelijk zeer selectieve groep werkenden. 


\subsection{Conclusie}

De economische crisis heeft in de periode 2008-2013 geleid tot een sterke stijging in het werkloosheidspercentage, namelijk van 3,7\% van de beroepsbevolking in 2008 naar $7,3 \%$ in 2013 . Het werkloosheidspercentage onder jongeren lag hierbij zowel vóór als ná het aanbreken van de crisis consequent boven het werkloosheidspercentage van de beroepsbevolking als geheel of het werkloosheidspercentage onder ouderen. Uit een verdere vergelijking van het werkloosheidspercentage onder jongeren met het werkloosheidspercentage onder de totale beroepsbevolking en het werkloosheidspercentage onder ouderen blijkt dat de werkloosheid het meest conjunctuurgevoelig is onder jongeren. De jeugdwerkloosheid steeg sterker tijdens de crisisjaren, maar was er op het moment dat de economie begon aan te trekken in 2014 al relatief snel een daling in de jeugdwerkloosheid zichtbaar, terwijl het werkloosheidspercentage onder de totale beroepsbevolking pas later begon te dalen en het werkloosheidspercentage onder ouderen zelfs in het tweede kwartaal van 2015 nog bleef stijgen.

Wat betreft werkloosheid zijn naast het verschil tussen jong en oud enkele opvallende verschillen tussen opleidingsniveaus zichtbaar. Zo blijkt dat het werkloosheidspercentage onder laagopgeleide jongeren systematisch hoger ligt dan het werkloosheidspercentage onder middelbaar of hoger opgeleide jongeren. Bovendien blijkt dit verschil in werkloosheidspercentage tussen middelbaar en hoger opgeleide jongeren enerzijds en lager opgeleide jongeren anderzijds de afgelopen twee jaar verder toe te nemen. Onder de oudere beroepsbevolking blijkt opleidingsniveau pas een rol te spelen vanaf 2011, wanneer er langzaam maar zeker een kloof ontstaat tussen de laag- en middelbaar opgeleiden aan de ene kant en de hoog opgeleiden aan de andere kant waarbij de laatstgenoemde groep een lager werkloosheidspercentage noteert dan de twee andere groepen. Vanuit beleidsoogpunt is dit een punt van zorg.

De afgelopen jaren nam het aandeel werknemers met een flexibele arbeidsrelatie gestaag toe. Dit is een trend die al voor de crisis werd ingezet en die de afgelopen jaren onverminderd heeft doorgezet. Deze trend blijkt echter het sterkst zichtbaar onder jongeren: hoewel flexibele arbeidsrelaties de afgelopen jaren weliswaar al veel vaker voorkwamen onder jongeren, is het aandeel jongeren met een flexibel contract de afgelopen 12 jaar ook sterker toegenomen dan gemiddeld. Hierdoor hadden in het tweede kwartaal van 2015 iets meer dan zeven op de tien jongeren (70,3\%) van 15-25 jaar een flexibele arbeidsrelatie, tegenover $27,4 \%$ van het totaal aantal werkenden. Bij jongeren met een flexibele aanstelling gaat het echter vaak om scholieren.

Voor de middellange termijn (tot 2020) wordt een jaarlijkse werkgelegenheidsgroei van gemiddeld $0,8 \%$ per jaar verwacht. Dit wijkt nauwelijks af van de gemiddelde jaarlijkse werkgelegenheidsgroei in de periode 1996-2014 (dit was 0,9\% op jaarbasis). Er zullen de komende jaren naar verwachting dus meer banen bijkomen dan verdwijnen. Als de beroepsbevolking in deze periode minder hard stijgt dan de werkgelegenheid, zal dit zich tevens vertalen in een verdere afname van het werkloosheidspercentage en een 
toename van de netto participatiegraad. De bedrijfssectoren waarvoor de sterkste groei wordt voorspeld zijn de bouwnijverheid (2,2\% per jaar) en de specialistische zakelijke dienstverlening (2,1\% per jaar). Voor de meeste andere sectoren wordt tevens een positieve werkgelegenheidsgroei verwacht, maar er zijn ook enkele sectoren met een verwachte werkgelegenheidskrimp. Naast enkele sectoren die in het verleden ook al met krimp te maken hadden, zoals de landbouw, bosbouw en visserij, de chemie en overige industrie, wordt er nu een krimp van de werkgelegenheid verwacht voor sectoren als energie, financiële dienstverlening en onroerend goed en openbaar bestuur en overheidsfinanciën. Dit terwijl deze sectoren in de periode 1996-2014 nog een (sterke) groei lieten zien.

Opvallend, en zeer bepalend voor de perspectieven naar opleiding en beroep die later aan bod komen in dit rapport, is de kanteling in de werkgelegenheidsontwikkeling in de zorgsector en de welzijnssector. Beide sectoren waren een belangrijke 'motor' van de werkgelegenheidsgroei in de jaren 1996-2014, maar deze werkgelegenheidsgroei wordt tot 2020 sterk geremd als gevolg van overheidsbezuinigingen. Wel dient opgemerkt te worden dat de werkgelegenheidsprognoses voor beide sectoren vooral negatief uitpakken aan het begin van de prognoseperiode, met een herstel tegen het einde van de periode.

De verwachte werkgelegenheidsgroei uitgesplitst naar beroepsklassen blijkt negatief te zijn voor de agrarische beroepen, waar een gemiddelde krimp van o,6\% op jaarbasis wordt verwacht. De sterkste groei binnen de beroepsklassen wordt daarentegen verwacht voor de ICT- en technische beroepen, waarvoor in beide gevallen een gemiddelde jaarlijkse groei van 1,2\% geprognosticeerd wordt. Een vergelijking van de werkgelegenheidsgroei naar opleidingsniveau leert dat de werkgelegenheidsgroei voor alle opleidingsniveaus positief is en weinig varieert tussen opleidingsniveaus.

Gezien het feit dat de gemiddelde jaarlijkse vervangingsvraag als percentage van de werkgelegenheid $2,9 \%$ bedraagt terwijl de gemiddelde jaarlijkse uitbreidingsvraag slechts $0,8 \%$ bedraagt, zal de vervangingsvraag de komende jaren veruit de belangrijkste component vormen voor het aantal baanopeningen. Aangezien hier een gemiddelde jaarlijkse arbeidsmarktinstroom van 3,1\% tegenover staat is de arbeidsmarkt de komende jaren bij benadering in balans met een aanbod dat slechts iets hoger ligt dan de verwachte vraag. De perspectieven voor basisonderwijs, vmbo en havo/vwo zijn zoals gezegd goed. Echter, dit komt voornamelijk doordat veel banen op dit opleidingsniveau door scholieren/studenten als (bij)baan worden vervuld zonder loopbaanpectieven: er is weliswaar een grote vraag naar scholieren in kleine banen, maar op de langere termijn zijn de loopbaanperspectieven, gemeten aan de doorgroei in loon, bepaald niet goed. Voor het mbo niveau 2/3 en 4 zijn de perspectieven matig, en de vraag/aanbod verhoudingen liggen duidelijk beter op hbo en wo niveau. Daar zijn de perspectieven redelijk, met een 'overschot' van het aanbod van maximaal $5 \%$ ten opzichte van de verwachte vraag. Bovendien zijn de verdere loopbaanperspectieven van hbo'ers en wo'ers goed tot zeer goed. Het aandeel jongeren waarvoor goede tot zeer goede perspectieven worden 
verwacht stijgt met het opleidingsniveau: op mbo $2 / 3$ niveau worden goed tot zeer goede perspectieven verwacht voor $3 \%$ van de gediplomeerden. Op mbo 4 niveau is dit $19 \%$ en op hbo en wo niveau zelfs 25 en $21 \%$.

Specifieke ontwikkelingen op de deelmarkten zullen bepalend zijn voor de vraag/ aanbod verhoudingen voor specifieke beroepen en opleidingen. Vraag en aanbod komen nader aan bod in hoofdstuk 2 . In hoofdstuk 3 staan we stil bij de perspectieven naar beroep en opleiding. 


\section{2 \\ ONTWIKKELINGEN IN VRAAG EN AANBOD 2015-2020}

\subsection{Inleiding}

In hoofdstuk 1 stonden de algemene ontwikkelingen op de arbeidsmarkt in de afgelopen jaren en de verwachte vraag- en aanbodontwikkelingen tot 2020 centraal. Deze verwachte ontwikkelingen in arbeid worden in dit hoofdstuk nader besproken voor 12 beroepsklassen en 22 opleidingscategorieën uit het mbo, hbo en wo. Als eerste bespreken we in paragraaf 2.2 de verwachte uitbreidingsvraag. Deze vraag ontstaat als gevolg van een toe- of afname van de werkgelegenheid. De uitbreidingsvraag naar beroep is onder meer afhankelijk van werkgelegenheidsverschuivingen tussen sectoren en verschuivingen in de beroepenstructuur binnen sectoren. De uitbreidingsvraag naar opleiding wordt afgeleid van de vraag naar beroepen, en is bovendien afhankelijk van de verhoging van kwalificatievereisten van werkgevers ('skill-upgrading') binnen beroepen. ${ }^{65}$ De verwachte vervangingsvraag naar beroep en opleiding komt aan bod in paragraaf 2.3. Deze vraag ontstaat als gevolg van vrijgekomen arbeidsplaatsen door bijvoorbeeld pensionering, arbeidsongeschiktheid of volledige of tijdelijke uittrede van de arbeidsmarkt vanwege huishoudelijke- of zorgtaken. Vervangingsvraag kan echter ook nog ontstaan wanneer werkenden van beroep (door mobiliteit) of opleidingsachtergrond (door bij- of nascholing) veranderen. De totale vraag naar nieuwkomers op de arbeidsmarkt, de baanopeningen, wordt bepaald door de optelsom van de vervangingsvraag en de positieve uitbreidingsvraag (i.e. nieuwe banen die ontstaan op de arbeidsmarkt). ${ }^{66}$ De baanopeningen naar beroep en opleiding worden besproken in paragraaf 2.4. De aanbodkant van de arbeidsmarkt wordt in paragraaf 2.5 in kaart gebracht waar de te verwachten stroom van schoolverlaters en afgestudeerden die gedurende de prognoseperiode de arbeidsmarkt zullen betreden wordt besproken. In deze paragraaf zetten we de verwachte instroom af tegen de instroom uit het recent verleden om verschuivingen in de studiekeuze van scholieren en studenten inzichtelijk te maken. ${ }^{67}$ De belangrijkste conclusies volgen in paragraaf 2.6 .

65 Merk op dat er in de loop der jaren sprake is van een geleidelijke afname in de mate waarin het opleidingsniveau van de werkenden stijgt (zie hoofdstuk 4).

66 Voor de methodologische verantwoording, zie: ROA (2015, te verschijnen), Methodiek arbeidsmarktprognoses en-indicatoren 2015-2020, ROA, Maastricht.

67 Verschuivingen in vraag en aanbod in de periode 1996-2014 komen aan bod in hoofdstuk 4. 
De in dit hoofdstuk gepresenteerde cijfers zijn de bouwstenen voor de perspectieven naar opleiding en beroep die in hoofdstuk 3 besproken worden. Een grote arbeidsvraag is op zichzelf niet genoeg om te kunnen concluderen dat de perspectieven goed zullen zijn. Er kan immers een nog groter arbeidsaanbod hier tegenover staan waardoor instromers op de arbeidsmarkt met elkaar moeten concurreren. In hoofdstuk 3 confronteren we het aanbod met de vraag.

\subsection{Uitbreidingsvraag}

In deze paragraaf wordt de werkgelegenheidsontwikkeling in de periode $2015-2020$ gepresenteerd aan de hand van de verwachte uitbreidingsvraag. Een positieve uitbreidingsvraag duidt op een toename van de werkgelegenheid voor de desbetreffende beroepsklasse, opleidingscategorie of arbeidsmarkt als geheel, terwijl een negatieve uitbreidingsvraag duidt op een werkgelegenheidsdaling.

\section{Uitbreidingsvraag naar beroep}

In tabel 2.1 zijn de uitbreidingsvraag in personen en de bijbehorende groeipercentages voor de periode 2015-2020 weergeven. De cijfers zijn zowel weergeven voor de arbeidsmarkt als geheel als gedifferentieerd naar de verschillende beroepsklassen. Voor de arbeidsmarkt als geheel wordt voor de komende zes jaar een toename in de werkgelegenheid van 400.300 personen verwacht, oftewel een totale toename van $5 \%$ in het totaal aantal werkenden ten opzichte van 2014. Dit komt neer op een gemiddelde jaarlijkse uitbreidingsvraag van $0,8 \%$ van de werkgelegenheid in 2014. De cijfers voor de afzonderlijke beroepsklassen laten zien dat er slechts binnen één beroepsklasse sprake is van een negatieve uitbreidingsvraag, namelijk bij de agrarische beroepen. Tot $2020 \mathrm{zal}$ de werkgelegenheid hier naar verwachting met $3 \%$ afnemen. ${ }^{68}$ De twee beroepsklassen waar de werkgelegenheid tot 2020 het sterkst zal toenemen zijn de ICT-beroepen en de technische beroepen. Er is echter wel degelijk veel variatie in de uitbreidingsvraag voor de onderliggende beroepsgroepen. Opvallende ontwikkelingen in de onderliggende beroepsgroepen wordt hier kort besproken.

68 Omdat het hier om een relatief kleine beroepsklasse in termen van het aantal werkenden gaat, is de krimp beperkt tot 6.800 werkenden. 
TABEL 2.1 Uitbreidingsvraag naar beroepsklasse, in aantal en als percentage van de werkgelegenheid in 2014, prognose 2015-2020

\begin{tabular}{|l|r|r|r|}
\hline & Aantal (6 jr.) & Totaal (6 jr.) \% & Gem. jaarlijks \% \\
\hline Pedagogische beroepen & 6.700 & 1 & 0,2 \\
\hline Creatieve en taalkundige beroepen & 11.000 & 5 & 0,9 \\
\hline Commerciële beroepen & 42.8000 & 5 & 0,7 \\
\hline Bedrijfseconomische en administratieve beroepen & 87.5000 & 6 & 1,0 \\
\hline Managers & 34.400 & 6 & 1,0 \\
\hline Openbaar bestuur, veiligheid en juridische beroepen & 13.600 & 5 & 0,8 \\
\hline Technische beroepen & 83.800 & 7 & 1,2 \\
\hline ICT-beroepen & 22.600 & 8 & 1,2 \\
\hline Agrarische beroepen & -6.800 & -3 & $-0,6$ \\
\hline Zorg- en welzijnsberoepen & 10.600 & 1 & 0,2 \\
\hline Dienstverlenende beroepen & 48.900 & 7 & 1,1 \\
\hline Transport- en logistiekberoepen & 32.400 & 6 & 0,9 \\
\hline Totaal (incl. overig) & 400.300 & 5 & 0,8 \\
\hline Bron: ROA (AIS)
\end{tabular}

Bron: ROA (AIS)

Voor de pedagogische beroepen wordt tot 2020 een werkgelegenheidsgroei van gemiddeld $0,2 \%$ per jaar verwacht. De groei is het sterkst bij de groep onderwijskundigen en overige docenten (1,2\% per jaar). De werkgelegenheid zal ook toenemen onder sportinstructeurs (0,9\% per jaar), docenten in het hoger onderwijs en hoogleraren (0,8\% per jaar) en onder docenten voor de algemene vakken in het secundair onderwijs ( $0,6 \%$ per jaar). Voor de docenten beroepsgerichte vakken in het secundair onderwijs en voor leerkrachten in het basisonderwijs wordt echter een krimp voorzien.

De creatieve en taalkundige beroepen laten een werkgelegenheidsgroei van gemiddeld $0,9 \%$ per jaar zien. Gezien de recente bezuinigingen binnen de cultuursector kan deze positieve werkgelegenheidsverwachtingen in eerste instantie als enigszins opmerkelijk worden beschouwd. De resultaten zijn echter minder opmerkelijk als men beseft dat personen met een creatief of taalkundig beroep voornamelijk werkzaam blijken te zijn in sectoren waarvoor de verwachte uitbreidingsvraag het grootst is, zoals de specialistische zakelijke dienstverlening. Bovendien zijn de werkgelegenheidsverwachtingen niet voor elk onderliggend beroep gunstig. Voor bibliothecarissen en conservatoren wordt bijvoorbeeld een krimp van 1,2\% van de werkgelegenheid voorspeld.

De werkgelegenheidsverwachtingen voor de commerciële beroepen zijn ook positief. Voor vijf van de zes onderliggende beroepsgroepen is de uitbreidingsvraag tot 2020 positief. Dit geldt vooral voor callcentermedewerkers outbound, overige verkopers, winkeliers en teamleiders in de detailhandel en kassamedewerkers (ruim 1\% groei per jaar). Dit vloeit voort uit de gunstige verwachte werkgelegenheidsontwikkeling in de groot- en kleinhandel (zie tabel 1.3). Alleen voor de beroepsgroep vertegenwoordigers en inkopers is de verwachting dat de werkgelegenheid de komende zes jaar zal krimpen. 
In het basisjaar 2014 was bijna 18\% van de werkenden werkzaam in bedrijfseconomische en administratieve beroepen. Hiermee is deze beroepsklasse in omvang de grootste. De komende zes jaar zal het aantal personen dat werkzaam is in bedrijfseconomische en administratieve beroepen naar verwachting toenemen met gemiddeld $1 \%$ per jaar. Binnen de betreffende beroepsklasse treft men echter zowel beroepsgroepen met een relatief sterke groei, als beroepsgroepen met een relatief sterke krimp aan. Voor negen van de in totaal dertien onderliggende beroepsgroepen wordt een positieve uitbreidingsvraag voorspeld. Vooral het aantal zakelijke dienstverleners en accountants zal relatief sterk toenemen. Het aantal secretaresses en het aantal boekhouders zal daarentegen relatief sterk afnemen. Dit geldt echter niet voor directiesecretaresses waarvoor een positieve uitbreidingsvraag verwacht wordt (ruim 2\% per jaar). Er lijkt dus sprake te zijn van verdwijning van de standaard secretaresse, mogelijk als gevolg van automatisering, maar tegelijkertijd ook van een specialisering van het secretarieel werk naar het niveau van directiesecretaresse. Ook voor boekhoudkundig medewerkers wordt een positieve uitbreidingsvraag verwacht terwijl voor de beroepsgroep boekhouders juist een krimp wordt voorzien. Er zijn nog twee andere beroepsgroepen waarvoor een krimp in de werkgelegenheid wordt voorzien, namelijk voor specialisten personeels- en loopbaanontwikkeling en voor beleidsadviseurs. De overige vijf groepen binnen de bedrijfseconomische en administratieve beroepen laten allen een groei zien.

De verwachte uitbreidingsvraag naar managers is gelijk aan de verwachte uitbreidingsvraag binnen de bedrijfseconomische en administratieve beroepen. Voor managers commerciële en persoonlijke dienstverlening en managers in de zakelijke en administratieve dienstverlening is de geschatte uitbreidingsvraag het hoogst met 3\% per jaar. De vooruitzichten zijn echter niet voor alle soorten managers even gunstig. Een krimpende werkgelegenheid wordt verwacht voor managers in de detail- en groothandel $(-2,8 \%$ per jaar) - mogelijk als gevolg van schaalvergroting -, managers in het onderwijs $(-1,1 \%$ per jaar) en managers in de horeca (-o,6\% per jaar).

Voor de beroepsklasse openbaar bestuur, veiligheid en juridische beroepen wordt een gemiddelde jaarlijkse uitbreidingsvraag van $0,8 \%$ verwacht. In de onderliggende beroepsgroepen zijn echter twee duidelijke uitschieters zichtbaar, namelijk bij het beveiligingspersoneel en bij de militaire beroepen. Voor beveiligingspersoneel - de grootste onderliggende beroepsgroep qua aantal werkenden - wordt een positieve uitbreidingsvraag verwacht ( $2,7 \%$ per jaar), terwijl voor militaire beroepen een negatieve uitbreidingsvraag wordt verwacht ( $-4 \%$ per jaar). Voor overheidsambtenaren (de op een na grootste beroepsgroep), maar ook voor juristen, is een positieve uitbreidingsvraag voorzien.

De beroepsklasse technische beroepen is na de beroepsklasse bedrijfseconomische en administratieve beroepen de grootste beroepsklasse qua aantal werkenden. In de periode 2015-2020 zal de vraag naar technici naar verwachting toenemen met gemiddeld 1,2\% per jaar. In de meeste onderliggende beroepsgroepen binnen deze beroepsklasse is sprake van een positieve uitbreidingsvraag. De uitbreidingsvraag is het positiefst 
onder ingenieurs (geen elektrotechniek), de grootste onder de in totaal 25 technische beroepsgroepen binnen deze klasse. Ondanks het feit dat dat de meeste technische beroepsgroepen een positieve uitbreidingsvraag laten zien, zijn er een aantal technische beroepsgroepen waarvoor toch een krimp in de werkgelegenheid wordt voorzien. Deze krimp is het grootst bij de biologen/natuurwetenschappers en elektrotechnisch ingenieurs. Er is ook sprake van een lichte krimp bij de productiemachinebedieners, meubelmakers, kleermakers en stoffeerders, metaalbewerkers en constructiewerkers en tot slot de lassers en plaatwerkers.

De beroepsklasse ICT-beroepen bestaat uit vier beroepsgroepen. Voor drie van deze groepen wordt een positieve uitbreidingsvraag voorzien, namelijk voor software- en applicatieontwikkelaars, gebruikersondersteuning ICT en radio- en televisietechnici. In het geval van de databank- en netwerkspecialisten zal de werkgelegenheid naar verwachting echter afnemen.

De enige beroepsklasse met een negatieve uitbreidingsvraag is de beroepsklasse agrarische beroepen. Het aantal werkenden in de agrarische beroepen zal de komende zes jaar naar verwachting met gemiddeld o,6\% per jaar krimpen. De krimp die zichtbaar is in deze beroepsklasse is ook zichtbaar in alle onderliggende beroepsgroepen.

Voor de beroepsklasse zorg en welzijn wordt een beperkte positieve uitbreidingsvraag van gemiddeld 0,2\% per jaar verwacht. Dit komt overeen met de verwachte uitbreidingsvraag in de sectoren zorg en welzijn (zie tabel 1.3). In de onderliggende beroepsgroep verzorgenden vindt naar verwachting groei noch krimp plaats. Daarnaast is de krimp die verwacht wordt voor psychologen en sociologen ( $0,2 \%$ over zes jaar) en beroepsgroep sociaal werkers, groeps- en woonbegeleiders (0,3\% over zes jaar) zo klein, dat deze groei op jaarbasis nauwelijks merkbaar is en bij afronding gelijk is aan $0 \%$. In het basisjaar 2014 blijkt bijna de helft van alle werkenden in de beroepsklasse zorg en welzijn in deze drie beroepsgroepen zonder significante groei werkzaam te zijn. Als ook de lage uitbreidingsvraag in beroepsgroepen zoals gespecialiseerd verpleegkundigen ( $0,1 \%$ per jaar), artsen (0,2\% per jaar) en fysiotherapeuten (idem) wordt meegenomen komen we tot de conclusie dat maar liefst $75 \%$ van de werkenden binnen deze beroepsklasse werkzaam is in beroepsgroepen die geen of nauwelijks groei in het aantal werkenden zullen doormaken de komende jaren. Dit verklaart het beperkte groeiperspectief van de beroepsklasse als geheel. Beroepsgroepen waarvoor wel duidelijk sprake is van een groeiende werkgelegenheid zijn de apothekersassistenten (1,6\% per jaar), de medisch praktijkassistenten ( $1,6 \%$ per jaar) en de medisch vakspecialisten (1,4\% per jaar). Hier staan echter ook enkele beroepsgroepen met een duidelijke krimp tegenover, zoals de verpleegkundigen (mbo) (1,3\% per jaar), de maatschappelijk werkers ( $0,5 \%$ per jaar) en de laboranten (o,4\% per jaar).

De dienstverlenende beroepen laten na de ICT- en technische beroepen de sterkste groei in het aantal werkenden zien de komende jaren. Ten opzichte van het basisjaar 2014 wordt voor deze beroepsgroep een jaarlijkse werkgelegenheidsgroei van gemid- 
deld 1,1\% verwacht. Bijna alle onderliggende beroepsgroepen vertonen een positieve uitbreidingsvraag (op conciërges en teamleiders schoonmaak na, waarvoor een krimp wordt verwacht). De grootste groei wordt verwacht voor verleners van overige persoonlijke diensten en keukenhulpen.

Het aantal personen dat werkzaam is in de beroepsklasse transport en logistiek zal de komende jaren met gemiddeld 0,9\% per jaar toenemen. Hoewel het aantal chauffeurs van auto's, taxi's en bestelwagens met $2 \%$ per jaar relatief sterk zal groeien, neemt zowel het aantal vrachtwagenchauffeurs als het aantal buschauffeurs en trambestuurders in verhouding minder sterk toe (0,2\% en 0,9\% per jaar). De lage verwachte werkgelegenheidsgroei voor vrachtwagenchauffeurs sluit aan bij de onlangs door het CBS geconstateerde afname van het aantal Nederlandse vrachtauto's in recente jaren. ${ }^{69}$ Naast vrachtwagenchauffeurs en trambestuurders is de werkgelegenheidsgroei ook relatief beperkt bij de bedieners van mobiele machines (0,2\% per jaar). Het aantal laders, lossers en vakkenvullers zal naar verwachting met 0,9\% per jaar groeien, het aantal dekofficieren en piloten met $1,4 \%$ en het aantal vuilnisophalers en dagbladbezorgers met $1,7 \%$ per jaar. Voor transportplanners en logistiek medewerkers wordt eveneens een positieve uitbreidingsvraag van 1,4\% per jaar verwacht.

\section{Uitbreidingsvraag naar opleiding}

De uitbreidingsvraag binnen de verschillende beroepsgroepen vormt de basis voor de uitbreidingsvraag naar opleidingstype. Bij de schatting van de uitbreidingsvraag naar opleidingstype wordt de uitbreidingsvraag binnen de verschillende beroepsgroepen herverdeeld over de opleidingstypes die werkzaam zijn in deze beroepsgroepen. In dit proces wordt expliciet rekening gehouden met eventuele verschuivingen in de samenstelling van opleidingen binnen beroepsgroepen over tijd (bijvoorbeeld als gevolg van upgrading of downgrading). Zo kan het bijvoorbeeld voorkomen dat binnen een bepaalde beroepsgroep het aandeel werkenden met als opleidingstype wo techniek (sterk) toeneemt over de tijd. ${ }^{70}$

In tabel 2.2 worden de prognoses van de uitbreidingsvraag naar opleidingscategorieën voor de jaren 2015-2020 gepresenteerd. De prognoses voor de uitbreidingsvraag zijn zowel in het aantal personen als in groeipercentages weergeven. De getoonde opleidingscategorieën zijn gesorteerd naar niveau en richting, waarbij enkel opleidingsca-

69 CBS (2015), Meer trekkers dan vrachtauto's, http://www.cbs.nl/nl-NL/menu/themas/verkeer-vervoer/publicaties/artikelen/archief/2015/meer-trekkers-dan-vrachtautos.htm. Hoewel het aantal vrachtauto's de afgelopen jaren gestaag afnam, bleef het aantal trekkers dat gebruikt werd voor wegtransport van goederen stabiel. Trekkers hebben een groter laadvermogen en worden voornamelijk gebruikt voor lange, internationale ritten terwijl vrachtauto's voornamelijk voor kortere, binnenlandse ritten worden gebruikt. Het ligt voor de hand dat de werkgelegenheid voor Nederlandse vrachtwagenchauffeurs sterker afhankelijk is van binnenlandse ritten (relatief vaker met vrachtauto) dan van internationale ritten (relatief vaker met trekker).

70 Het opleidingenmodel van de uitbreidingsvraag houdt hier rekening mee door voor elke opleidingsberoepsgroep combinatie een trend te schatten en deze trend te gebruiken in de herverdeling van de uitbreidingvraag naar opleidingstype. Daarnaast wordt er in het model rekening gehouden met de interacties met de aanbodzijde van de arbeidsmarkt (substitutievraag). 
tegorieën vanaf mbo 2/3 zijn weergeven. ${ }^{71}$ De tabel laat veel variatie zien in de uitbreidingsvraag naar opleidingsrichtingen.

De opleidingsrichting techniek doet het binnen elk opleidingsniveau het beste, maar ook de economische opleidingen (mbo economie, hbo economie en wo economie en recht) laten binnen elk opleidingsniveau een relatief hoge uitbreidingsvraag zien. Het feit dat de uitbreidingsvraag voor zowel de technische als economische opleidingscategorieën iets hoger is op hbo- en wo-niveau dan op de mbo-niveaus wijst op licht verhoogde kwalificatievereisten ('upgrading') van werkgevers in de sectoren waarin afgestudeerden van deze opleidingstypes voornamelijk werkzaam zijn.

De prognoses van de uitbreidingsvraag voor de opleidingsniveaus mbo $2 / 3$ en mbo 4 zijn vrijwel identiek aan elkaar. In beide gevallen stijgt de uitbreidingsvraag naar mbo techniek het snelst ( $1 \%$ per jaar voor beide niveaus), gevolgd door mbo economie (in beide gevallen $0,8 \%$ per jaar), mbo zorg en welzijn (beide $0,4 \%$ per jaar) en tot slot mbo groen (o,4\% per jaar op niveau $2 / 3$ en 0,5\% per jaar op niveau 4).

Net als bij alle andere opleidingsniveaus laat de richting techniek ook binnen het hbo de sterkste uitbreidingsvraag zien. Naast hbo techniek doen hbo taal en cultuur en hbo economie het ook relatief goed in termen van verwachte werkgelegenheidsgroei. Van alle opleidingsrichtingen binnen het hbo is de geschatte uitbreidingsvraag het laagst voor hbo onderwijs.

Binnen de opleidingscategorieën in het hbo is soms sprake van een hoge mate van heterogeniteit tussen de onderliggende opleidingstypes. Dit is bijvoorbeeld zichtbaar bij de opleidingsrichting onderwijs: Voor hbo leraar basisonderwijs wordt een krimp van gemiddeld -0,1\% per jaar verwacht, terwijl voor hbo leraar beroepsgerichte vakken een positieve uitbreidingsvraag van gemiddeld $0,5 \%$ per jaar wordt verwacht en voor hbo leraar algemene vakken zelfs een groei van 1,2\% per jaar.

Voor wetenschappelijk opgeleiden wordt de hoogste uitbreidingsvraag verwacht bij wo techniek, gevolgd door wo economie en recht en wo taal en cultuur. De laagste groei wordt daarentegen verwacht bij wo onderwijs en wo medisch (beide 0,3\% per jaar). Ook binnen de opleidingsrichtingen uit het wo zijn echter enkele noemenswaardige verschillen tussen de onderliggende opleidingstypes aanwezig. Binnen wo taal en cultuur wordt voor het opleidingstype wo taal, cultuur en journalistiek een uitbreidingsvraag van gemiddeld $0,7 \%$ per jaar verwacht en voor de overige opleidingstypes een uitbreidingsvraag van $1 \%$ per jaar. Bij wo economie en recht is de uitbreidingsvraag voor wo accountancy en financiën met gemiddeld 1,5\% per jaar licht positiever dan bij de overige opleidingstypes, waar de uitbreidingsvraag telkens tussen de 0,9-1,1\% per

71 Hoewel er voor sommige beroepsgroepen een negatieve uitbreidingsvraag geprognotiseerd wordt, geldt voor de meeste opleidingscategorieën dat de verwachte uitbreidingsvraag positief is. Dit komt doordat er geen één op één relatie is tussen opleiding en beroep, waardoor de vraag naar een specifieke opleiding beïnvloedt wordt door de vraag vanuit vele beroepen. 
jaar ligt. Binnen de opleidingsrichting wo landbouw en natuur is de verwachte uitbreidingsvraag voor wo biologie, wiskunde, landbouw en milieu met 0,4\% per jaar iets lager dan de geprognosticeerde uitbreidingsvraag voor wo natuur- en scheikunde (0,6\% per jaar). Het verschil is echter minimaal, en de iets lagere groei voor wo biologie, wiskunde, landbouw en milieu is waarschijnlijk voornamelijk gedreven door het feit dat de uitbreidingsvraag binnen de agrarische beroepen als enige negatief is (zie tabel 2.1).

TABEL 2.2 Uitbreidingsvraag naar opleidingscategorie, in aantal en als percentage van de werkgelegenheid in 2014, prognose 2015-2020

\begin{tabular}{|c|c|c|c|}
\hline & Aantal ( $6 \mathrm{jr})$. & Totaal (6 jr.) \% & Gem. jaarlijks \% \\
\hline mbo $2 / 3$ groen & 1.200 & 2 & 0,4 \\
\hline mbo $2 / 3$ economie & 23.400 & 5 & 0,8 \\
\hline mbo 2/3 techniek & 28.100 & 6 & 1,0 \\
\hline mbo 2/3 zorg en welzijn & 8.400 & 3 & 0,4 \\
\hline mbo 4 groen & 1.500 & 2 & 0,4 \\
\hline mbo 4 economie & 23.900 & 5 & 0,8 \\
\hline mbo 4 techniek & 23.300 & 6 & 1,0 \\
\hline mbo 4 zorg en welzijn & 9.300 & 3 & 0,5 \\
\hline hbo onderwijs & 2.300 & 1 & 0,2 \\
\hline hbo taal en cultuur & 8.500 & 6 & 1,0 \\
\hline hbo economie & 30.700 & 6 & 0,9 \\
\hline hbo techniek & 22.100 & 7 & 1,1 \\
\hline hbo landbouw en natuur & 1.900 & 3 & 0,5 \\
\hline hbo gezondheidszorg & 5.100 & 2 & 0,4 \\
\hline hbo gedrag en maatschappij & 5.800 & 3 & 0,4 \\
\hline wo onderwijs & 1.000 & 2 & 0,3 \\
\hline wo taal en cultuur & 7.400 & 5 & 0,8 \\
\hline wo economie en recht & 24.000 & 6 & 1,0 \\
\hline wo techniek & 10.200 & 7 & 1,1 \\
\hline wo landbouw en natuur & 2.100 & 3 & 0,5 \\
\hline wo medisch & 2.600 & 2 & 0,3 \\
\hline wo gedrag en maatschappij & 4.200 & 4 & 0,6 \\
\hline Totaal (incl. overig) & 400.300 & 5 & 0,8 \\
\hline
\end{tabular}

Bron: ROA (AIS)

\subsection{Vervangingsvraag}

De vervangingsvraag is het tweede onderdeel van de totale vraag naar arbeid. De vervangingsvraag is de vraag die ontstaat doordat mensen de arbeidsmarkt (tijdelijk) verlaten. Veelvoorkomende redenen om de arbeidsmarkt te verlaten zijn bijvoorbeeld (vervroegd) pensioen, arbeidsongeschiktheid, werkloosheid, (tijdelijke) uittreding om de zorg voor kinderen op zich te nemen en migratie. Elke vorm van uittreding creëert de behoefte aan een nieuwe werkende met hetzelfde beroep of met dezelfde opleidingsachtergrond als degene die de arbeidsmarkt verlaat. Hierop is één uitzondering, namelijk 
wanneer er een daling in de werkgelegenheid waargenomen wordt voor het beroep of de opleidingsachtergrond van degene die de arbeidsmarkt verlaat. In een dergelijk geval (dus bij een negatieve uitbreidingsvraag) is vervanging niet nodig. Daarnaast houdt de vervangingsvraag naar opleiding rekening met skill-upgrading. ${ }^{22}$ Laagopgeleiden die de arbeidsmarkt verlaten nemen ervaring mee, en het is dan ook niet aannemelijk dat zij vervangen zullen worden door uitsluitend laagopgeleide intreders. Gelet op de stijging van het opleidingsniveau in de beroepenstructuur (zie hoofdstuk 4), wordt dan ook een deel van de vervangingsvraag voor de lage opleidingsniveaus doorgeschoven naar hogere opleidingsniveaus.

Naast het historisch verloop van werkenden, spelen de demografische ontwikkelingen in de beroepsbevolking gedurende de prognoseperiode een belangrijke rol in de vervangingsvraag. Een stijging van het aandeel oudere werkenden in de beroepsbevolking resulteert in een toename van de toekomstige vervangingsvraag, aangezien een gedeelte van deze groep gezien hun leeftijd in de nabije toekomst weer met pensioen zal gaan. Daarnaast spelen verwachte veranderingen in de arbeidsparticipatie ook een rol: bij een verwachte toename van de participatiegraad van ouderen zal de vervangingsvraag dalen.

\section{Vervangingsvraag naar beroep}

In tabel 2.3 worden de prognoses voor de vervangingsvraag naar beroepsklasse gepresenteerd voor de periode 2015-2020. Er worden 12 beroepsklassen onderscheiden. Voor elke beroepsklasse wordt de vervangingsvraag in absolute aantallen voor de gehele prognoseperiode weergegeven, alsook de vervangingsvraag voor de gehele prognoseperiode als percentage van de werkgelegenheid in 2014. Daarnaast is de jaarlijkse procentuele vervangingsvraag als percentage van de werkgelegenheid in 2014 weergegeven. De totale vervangingsvraag in absolute aantallen over de 6 prognosejaren is ruim 1,5 miljoen. Dit wil zeggen dat er tot 2020 ruim 1,5 miljoen arbeidskrachten naar verwachting vervangen moeten worden omdat zij van beroep wisselen of de arbeidsmarkt verlaten om bijvoorbeeld met (vervroegd) pensioen te gaan. Dit betekent dat ten opzichte van het werkgelegenheidsniveau in 2014 gemiddeld jaarlijks 2,9\% van de werkenden vervangen moet worden. Dit jaarlijks gemiddelde is vergelijkbaar met dat van de vorige prognoses tot $2018(2,8 \%)$ en is wat lager dan de jaren daarvoor omdat enerzijds de arbeidsparticipatie van ouderen blijft toenemen ${ }^{73}$ en anderzijds minder beroepenmobiliteit plaatsvindt in economisch roerige tijden. ${ }^{74}$

72 Skills upgrading houdt in dat mensen gedurende hun carrière een baan hebben bereikt waarvoor nu een hoger opleidingsniveau vereist is dan het opleidingsniveau dat de vertrekkende werknemer heeft. In het prognosemodel stijgt de vervangingsvraag voor hoger opgeleiden (hbo en wo) met ongeveer $24 \%$ als gevolg van skills upgrading in de vervangingsvraag. Zie ook hoofdstuk 4.

73 Arts, K.en F.Otten (2015), Gemiddelde pensioenleeftijd vanaf 2006 in de lift, Tijdschrift voor Arbeidsvraagstukken, 31(3): 354-360.

74 Loog, B., W. Smits en R. de Vries (2014), Arbeidsmarktdynamiek in Nederland: 2003-2013, Tijdschrift voor Arbeidsvraagstukken, 30(1): 27-39. 
TABEL 2.3 Vervangingsvraag naar beroepsklasse, in aantal en als percentage van de werkgelegenheid in 2014, prognose 2015-2020

\begin{tabular}{|l|c|r|r|}
\hline & Aantal $(6$ jr.) & Totaal $(6$ jr.) \% & Gem. jaarlijks \% \\
\hline Pedagogische beroepen & 89.600 & 16 & 2,5 \\
\hline Creatieve en taalkundige beroepen & 31.800 & 16 & 2,5 \\
\hline Commerciële beroepen & 157.100 & 17 & 2,6 \\
\hline Bedrijfseconomische en administratieve beroepen & 197.900 & 14 & 2,1 \\
\hline Managers & 106.200 & 20 & 3,1 \\
\hline Openbaar bestuur, veiligheid en juridische beroepen & 49.200 & 18 & 2,7 \\
\hline Technische beroepen & 200.800 & 17 & 2,7 \\
\hline ICT-beroepen & 29.800 & 10 & 1,6 \\
\hline Agrarische beroepen & 73.700 & 37 & 5,4 \\
\hline Zorg- en welzijnsberoepen & 137.400 & 12 & 2,0 \\
\hline Dienstverlenende beroepen & 174.900 & 24 & 3,6 \\
\hline Transport- en logistiekberoepen & 227.800 & 40 & 5,7 \\
\hline Totaal (incl. overig) & 1.510 .600 & 18 & 2,9 \\
\hline
\end{tabular}

Bron: ROA (AIS)

Er zijn veel verschillen in de vervangingsvraag tussen de 12 beroepsklassen. De hoogste jaarlijkse vervangingsvraag wordt verwacht voor de transport- en logistiekberoepen ( $5,7 \%$ per jaar) en de agrarische beroepen (5,4\% per jaar). De laagste vervangingsvraag wordt voorzien voor de ICT (1,6\% per jaar), een beroepsklasse die relatief jong is qua leeftijdsopbouw (zie hoofdstuk 4), en zorg- en welzijnsberoepen ( $2 \%$ per jaar). We gaan nu achtereenvolgens in op de vervangingsvraag van deze beroepsklassen en de achterliggende beroepsgroepen.

De gemiddelde jaarlijkse vervangingsvraag voor de pedagogische beroepen is 2,5\%. De vervangingsvraag voor leerkrachten basisonderwijs is met $2 \%$ het laagst binnen deze beroepsklasse. Voor sportinstructeurs is de vervangingsvraag met 3\% het hoogste. Al met al is er binnen de pedagogische beroepen geen grote spreiding in de vervangingsvraag. Dit is duidelijk anders bij de creatieve en taalkundige beroepen. Ook hier geldt een gemiddelde jaarlijkse vervangingsvraag van 2,5\%, maar voor de onderliggende beroepsgroepen loopt de vervangingsvraag veel meer uiteen. Terwijl voor de grafische vormgevers en productontwerpers slechts een vervangingsvraag onder de $1 \%$ wordt verwacht, is de vervangingsvraag naar beeldend kunstenaars en bibliothecarissen en conservatoren relatief hoog. ${ }^{75}$ De verschillen in de gemiddelde leeftijd van de werkenden in deze beroepsgroepen liggen deels hieraan ten grondslag. Omdat de grafische vormgevers en productontwerpers gemiddeld genomen veel jonger zijn dan de beeldend kunstenaars en bibliothecarissen en conservatoren vindt er de komende jaren veel minder uittreding plaats in de eerstgenoem de beroepsgroep.

De gemiddelde jaarlijkse vervangingsvraag voor de commerciële beroepen is $2,6 \%$. Echter, ook tussen de commerciële beroepen loopt de vervangingsvraag uiteen. Deze is

75 Merk op dat het aantal werkenden in laatstgenoemde beroepsgroep erg laag is en dat dit aantal niet veel veranderd in de periode die gebruikt is voor de schatting van het model. 
relatief laag onder winkeliers en teamleiders detailhandel (een half procent per jaar) en relatief hoog voor kassamedewerkers (4,7\% per jaar). De relatief hoge vervangingsvraag voor kassamedewerkers is voor een groot deel te wijten aan de hoge beroepenmobiliteit in deze beroepsgroep. Een groot deel van de kassamedewerkers is scholier en zij wisselen daardoor relatief vaak van baan. ${ }^{76}$

De bedrijfseconomische en administratieve beroepen hebben met 2,1\% een vervangingsvraag net onder het landelijke gemiddelde. De vervangingsvraag naar secretaresses (3,3\% per jaar) en receptionisten en telefonisten (3\% per jaar) is het hoogste binnen deze beroepsklasse. De boekhoudkundig medewerkers hebben daarentegen de laagste vervangingsvraag ( $1 \%$ per jaar). Ook binnen de groep managers, die gemiddeld genomen een jaarlijkse vervangingsvraag van 3,1\% hebben, loopt de vervangingsvraag uiteen. Onder de managers verkoop en marketing is de vervangingsvraag het laagst. De vervangingsvraag onder de managers gespecialiseerde dienstverlening alsook onder de managers commerciële en persoonlijke dienstverlening is daarentegen het hoogst (ruim $5,5 \%$ per jaar).

De beroepsgroepen die samen het openbaar bestuur, veiligheid en juridische beroepen vormen hebben een gemiddelde jaarlijkse vervangingsvraag van $2,7 \%$. Ook binnen deze beroepsklasse is er veel verschil in de vervangingsvraag van de onderliggende beroepsgroepen. Terwijl de vervangingsvraag onder politie-inspecteurs juist erg laag is (1,4\% per jaar), is deze onder de overheidsbestuurders relatief hoog ( $4,2 \%$ per jaar).

Dezelfde jaarlijkse vervangingsvraag van $2,7 \%$ wordt tevens verwacht voor de technische beroepen. Ook hier valt een hoge mate van heterogeniteit in de vervangingsvraag naar beroepsgroep waar te nemen. De biologen en natuurwetenschappers, alsook de loodgieters en pijpfitters hebben een erg lage vervangingsvraag (onder de 1\%). De productieleiders industrie en bouw, de meubelmakers, kleermakers en stoffeerders, de elektriciens en elektronicamonteurs, en de schilders en metaalspuiters hebben juist een relatief hoge vervangingsvraag van boven de $4 \%$ per jaar.

De ICT-beroepen hebben een gemiddelde jaarlijkse vervangingsvraag van 1,6\%. Deze beroepsklasse is op te delen in twee groepen: ICT-beroepen met een vervangingsvraag van rond de $1 \%$ (software- en applicatieontwikkelaars, en databank- en netwerkspecialisten), en ICT-beroepen met een vervangingsvraag van rond de $4 \%$ (gebruikersondersteuning ICT, radio- en televisietechnici). Het verschil in de vervangingsvraag van deze ICT-beroepen is mogelijk te verklaren uit de grote mobiliteit van jongeren in en uit de beroepen gebruikersondersteuning ICT en radio- en televisietechnici.

De agrarische beroepen hebben na de transport- en logistiekberoepen de hoogste gemiddelde vervangingsvraag. Verwacht wordt dat jaarlijks 5,4\% van de werkenden in de agrarische beroepen vervangen moet worden in de periode 2016-2020. Dit percen-

76 In het beroepssegment verkopers, dat onder andere de kassamedewerkers omvat, is $17 \%$ van de werkenden scholier tussen de 15 en 19 jaar. 
tage is hoog door de hoge gemiddelde leeftijd in deze beroepsklasse, en zou waarschijnlijk nog hoger uitvallen als het model voor de schatting van de vervangingsvraag geen rekening hield met de krimp die in deze beroepen plaatsvond. ${ }^{77}$ De beroepsgroep veetelers heeft de laagste vervangingsvraag binnen deze beroepsklasse, maar deze is nog steeds duidelijk hoger dan gemiddeld in Nederland. De hulpkrachten landbouw hebben met $6,5 \%$ de hoogste jaarlijkse vervangingsvraag binnen deze beroepsklasse. Ook hier is sprake van een groot aandeel (27\%) scholieren (15-19 jarigen), die vaak mobiel zijn (waarschijnlijk door seizoensgebonden arbeid of kleine banen), maar wel degelijk aan een vraag vanuit werkgevers beantwoorden.

De zorg- en welzijnsberoepen hebben met $2 \%$ een relatief lage vervangingsvraag door een gemiddeld genomen lage beroepenmobiliteit. De medisch praktijkassistenten en de medisch vakspecialisten hebben een relatief lage jaarlijkse vervangingsvraag van onder de 1,5\%. De apothekersassistenten hebben daarentegen de hoogste jaarlijkse vervangingsvraag binnen deze beroepsklasse (3,1\% per jaar): de mobiliteit in en uit het beroep is immers groot. ${ }^{78}$

De dienstverlenende beroepen hebben een gemiddelde jaarlijkse vervangingsvraag van 3,6\%. Voornamelijk onder de keukenhulpen, schoonmakers en kelners en barpersoneel is de vervangingsvraag hoog. Wederom gaat het hier om beroepsgroepen met een hoog aandeel scholieren/studenten die vaak nog van beroep wisselen. Het aandeel van de vervangingsvraag dat te wijten is aan beroepenmobiliteit is binnen deze beroepsgroepen dus relatief hoog.

De transport- en logistiekberoepen hebben de hoogste gemiddelde vervangingsvraag. $5,7 \%$ van de werkenden in deze beroepsklasse moet jaarlijks vervangen worden. De vuilnisophalers en dagbladenbezorgers hebben de hoogste vervangingsvraag van alle beroepsgroepen: $11,4 \%$ van hen moet jaarlijks vervangen worden. Ook hier geldt weer dat het hoge aandeel scholieren/studenten hieraan ten grondslag ligt. De vrachtwagenchauffeurs ( $3,7 \%$ per jaar) en bedieners mobiele machines ( $3,5 \%$ per jaar) hebben binnen deze beroepsklasse de laagste jaarlijkse vervangingsvraag.

\section{Vervangingsvraag naar opleiding}

De vervangingsvraag naar opleiding wordt, zoals eerder beschreven, niet alleen veroorzaakt door (tijdelijke) uittreding uit de arbeidsmarkt maar ook doordat mensen doorleren. Vooral voor de lage opleidingscategorieën is het aandeel van de vervangingsvraag dat toe te wijzen is aan het doorleren relatief groot. In combinatie met de kleine banen ( $<12$ uur) is dit ook de reden dat de vervangingsvraag voor alle opleidingscategorieën onder het niveau van mbo $2 / 3$ hier niet expliciet vermeld is.

77 In beroepen waar structureel geen instroom wordt waargenomen, wordt geen vervangingsvraag gerekend omdat er dan van uitgegaan wordt dat het beroep aan het verdwijnen is. De vervangingsvraag voor agrarische beroepen suggereert dan ook dat er ondanks de structurele krimp in de sector nog wel degelijk instroom plaats vindt in de beroepen.

SBA (2015), SBA Arbeidsmarktmonitor Apotheekbranche 2015, SBA: Nieuwegein. 
In tabel 2.4 is voor alle mbo 2/3, mbo 4, hbo en wo opleidingscategorieën weergegeven wat de vervangingsvraag over de prognoseperiode in absolute aantallen en in percentage van het aantal werkenden in 2014 is. Ook is de gemiddelde jaarlijkse vervangingsvraag weergegeven. Over de hele prognoseperiode van 6 jaar is de totale vervangingsvraag 1,5 miljoen (inclusief de vervangingsvraag van basisonderwijs, vmbo en havo/ vwo). Dit komt neer op 2,9\% van de werkgelegenheid in 2014.

Onder de mbo $2 / 3$ opleidingscategorieën wordt de hoogste vervangingsvraag voor mbo $2 / 3$ groen verwacht: $4,4 \%$ van de werkenden met deze opleidingsachtergrond zal naar verwachting in de prognoseperiode jaarlijks vervangen worden. De vervangingsvraag naar werkenden met een mbo $2 / 3$ zorg en welzijn opleidingsachtergrond is met $2,2 \%$ juist het laagste onder de mbo $2 / 3$ opleidingscategorieën. Vooral bij het opleidingstype mbo $2 / 3$ schoonheids- en haarverzorging is de vervangingsvraag relatief laag. De vervangingsvraag voor mbo $2 / 3$ economie en mbo $2 / 3$ techniek ligt rond de $3 \%$. Terwijl de onderliggende opleidingstypen bij mbo $2 / 3$ allemaal ongeveer gelijk zijn (3\%), zijn er veel verschillen bij de onderliggende mbo $2 / 3$ economie opleidingstypen. Voor mbo $2 / 3$ secretarieel wordt de jaarlijkse vervangingsvraag geschat op $1,9 \%$, en voor $\mathrm{mbo} 2 / 3$ recreatie, vrije tijd en sport op 6,0\%.

De mbo 4 opleidingscategorieën hebben een lagere vervangingsvraag dan de vergelijkbare mbo $2 / 3$ opleidingscategorieën. De jaarlijkse vervangingsvraag naar mbo 4 groen is met 2,2\% slechts de helft van de vervangingsvraag naar mbo $2 / 3$ groen. Voor mbo 4 economie en mbo 4 techniek is de vervangingsvraag met $2,1 \%$ ongeveer gelijk aan mbo 4 groen. De drie onderliggende opleidingstypen met de laagste jaarlijkse vervangingsvraag zijn mbo 4 horeca $(0,9 \%)$, mbo 4 informatica $(0,4 \%)$ en mbo 4 recreatie, vrijetijd en sport (0,5\%). Er zijn ook twee mbo 4 techniek opleidingstypen met een vergelijkbaar lage vervangingsvraag. Het betreft mbo 4 operator (o,6\%) en mbo 4 transport en logistiek (1\%). Daarentegen is de jaarlijkse vervangingsvraag voor mbo 4 media en vormgeving met $3,0 \%$ het hoogste onder de technische mbo 4 opleidingstypen. 
TABEL 2.4 Vervangingsvraag naar opleidingscategorie, in aantal en als percentage van de werkgelegenheid in 2014, prognose 2015-2020

\begin{tabular}{|c|c|c|c|}
\hline & Aantal (6 jr.) & Totaal (6 jr.) \% & Gem. jaarlijks \% \\
\hline mbo $2 / 3$ groen & 15.500 & 29 & 4,4 \\
\hline mbo $2 / 3$ economie & 95.100 & 20 & 3,2 \\
\hline mbo $2 / 3$ techniek & 84.600 & 19 & 3,0 \\
\hline mbo $2 / 3$ zorg en welzijn & 46.100 & 14 & 2,2 \\
\hline mbo 4 groen & 9.700 & 14 & 2,2 \\
\hline mbo 4 economie & 63.200 & 13 & 2,1 \\
\hline mbo 4 techniek & 48.700 & 13 & 2,1 \\
\hline mbo 4 zorg en welzijn & 33.400 & 11 & 1,8 \\
\hline hbo onderwijs & 53.700 & 24 & 3,7 \\
\hline hbo taal en cultuur & 15.800 & 12 & 1,9 \\
\hline hbo economie & 43.200 & 8 & 1,3 \\
\hline hbo techniek & 68.000 & 22 & 3,3 \\
\hline hbo landbouw en natuur & 12.500 & 19 & 2,9 \\
\hline hbo gezondheidszorg & 22.400 & 11 & 1,7 \\
\hline hbo gedrag en maatschappij & 35.300 & 16 & 2,5 \\
\hline wo onderwijs & 10.100 & 16 & 2,5 \\
\hline wo taal en cultuur & 21.700 & 14 & 2,3 \\
\hline wo economie en recht & 46.800 & 12 & 2,0 \\
\hline wo techniek & 37.200 & 26 & 3,9 \\
\hline wo landbouw en natuur & 18.700 & 25 & 3,8 \\
\hline wo medisch & 20.500 & 14 & 2,2 \\
\hline wo gedrag en maatschappij & 21.600 & 19 & 2,9 \\
\hline Totaal (incl. overig) & 1.520 .000 & 19 & 2,9 \\
\hline
\end{tabular}

Bron: ROA (AIS)

De vervangingsvraag naar hbo opleidingscategorieën loopt behoorlijk uiteen. Hbo onderwijs heeft de hoogste vervangingsvraag. Jaarlijks moet 3,7\% van de werkenden met een hbo-opleiding in de onderwijsrichting de komende 6 jaar vervangen worden. Ook voor hbo techniek geldt een vervangingsvraag van boven de $3 \%$. In deze opleidingscategorie is de vervangingsvraag voor de onderliggende opleidingstypen behoorlijk uiteenlopend. Terwijl voor hbo chemie de vervangingsvraag slechts $1,1 \%$ is, is de vervangingsvraag voor hbo elektrotechniek met 5,2\% relatief hoog. Voor hbo landbouw en natuur geldt een vervangingsvraag die met $2,9 \%$ gelijk is aan het landelijke gemiddelde. Hbo gedrag en maatschappij heeft een vervangingsvraag van $2,5 \%$.

De overige drie hbo opleidingscategorieën hebben een relatief lage vervangingsvraag: hbo economie $(1,3 \%)$, hbo gezondheidszorg $(1,7 \%)$ en hbo taal en cultuur $(1,9 \%)$. Binnen hbo economie lopen de onderliggende vervangingsvraagpercentages uiteen van $0,7 \%$ voor hbo hotel, vrijetijd en facility management tot $2,5 \%$ voor hbo accountancy en financiën. 
De vervangingsvraag voor wo opleidingscategorieën loopt uiteen van $2 \%$ (wo economie en recht) tot 3,9\% (wo techniek). De relatief lage vervangingsvraag voor wo medisch $(2,2 \%)$ is een gemiddelde van een erg lage vervangingsvraag voor wo gezondheidszorg $(1,2 \%)$ en een gemiddelde vervangingsvraag voor wo (dier)geneeskunde en tandheelkunde $(3,0 \%)$. Ook binnen wo taal en cultuur zijn grote verschillen in de onderliggende opleidingstypen: wo taal, cultuur en journalistiek $(1,3 \%)$, wo communicatie $(4,0 \%)$ en wo kunst $(3,9 \%)$.

Al met al lijkt het er op dat opleidingen in de zorg en welzijn op alle niveaus niet alleen last hebben van een lage uitbreidingsvraag als gevolg van bezuinigingen (zie paragraaf 2.2), maar ook van een relatief lage vervangingsvraag als gevolg van de lage mobiliteit uit die beroepen. Dit zal van tekenend zijn voor de perspectieven naar opleiding en beroep (zie hoofdstuk 3).

\subsection{Baanopeningen}

De optelling van de positieve uitbreidingsvraag en de vervangingsvraag geeft de totale vraag naar nieuwkomers op de arbeidsmarkt weer. ${ }^{79}$ Deze totale vraag wordt uitgedrukt in het aantal baanopeningen. De vervangingsvraag zal de grootste rol spelen bij het aantal baanopeningen, omdat er in de komende jaren meer vervanging zal optreden op de arbeidsmarkt dan uitbreiding van de werkgelegenheid. In deze paragraaf komen de baanopeningen per beroep en opleiding aan bod.

\section{Baanopeningen naar beroep}

Tabel 2.5 geeft de prognoses weer van het aantal baanopeningen per beroepsklasse. Naast de absolute aantallen in baanopeningen, laat deze tabel de baanopeningen ook zien als aandeel van de totale werkgelegenheid in 2014 (basisjaar). De laatste kolom laat het aandeel van de vervangingsvraag zien in het aantal baanopeningen. ${ }^{80}$ Voor de prognosejaren 2015-2020 worden in totaal bijna 2 miljoen baanopeningen verwacht. ${ }^{81}$ Dit komt neer op een jaarlijks gemiddelde van 3,7\% van de totale werkgelegenheid in 2014. Van al deze baanopeningen zal het grootste deel bepaald worden door de vervangingsvraag, namelijk $76 \%$. De overige baanopeningen (24\%) ontstaan als gevolg van de uitbreidingsvraag. Ter vergelijking: twee jaar geleden was het aandeel van de vervangingsvraag in het totaal aantal baanopening $83 \% .^{82}$ De groeiperspectieven waar nu mee wordt gerekend zorgen ervoor dat werkgelegenheidscreatie een belangrijkere rol speelt in de totale vraag dan twee jaar geleden.

79 Een belangrijke kanttekening is dat de gerapporteerde cijfers in deze paragraaf niet afgeleid kunnen worden uit de eerdere gepresenteerde uitbreiding- en vervangingsvraag. In de berekening van het aantal baanopeningen wordt alleen de positieve uitbreidingsvraag meegenomen, waarbij uitgegaan wordt van de onderliggende beroepsgroepen en opleidingstypen.

80 Het resterende deel bestaat uit de uitbreidingsvraag, omdat de optelsom van de uitbreidings- en vervangingsvraag het aantal baanopeningen vormt (wordt niet in de tabel weergeven).

81 Het gaat hier om baanopeningen in aantal personen in de leeftijd 15-74 jaar voor minimaal 1 uur.

82 ROA (2013), De arbeidsmarkt naar opleiding en beroep tot 2018, ROA, Maastricht: ROA-R-2013/11, pp. 42. 
De verschillen in vervangings- en uitbreidingsvraag tussen de 12 beroepsklassen resulteren in grote verschillen in het aantal baanopeningen tussen beroepsklassen. In de periode 2015-2020 zullen de meeste baanopeningen ontstaan in de transport- en logistiekberoepen ten opzichte van het gemiddelde aantal baanopeningen over alle beroepsklassen tezamen (6,5\% respectievelijk 3,7\%). In de agrarische beroepen zullen naar verwachting echter ook relatief veel baanopeningen ontstaan: per jaar wordt verwacht dat de vraag naar nieuwkomers in deze beroepsklasse gemiddeld $5,4 \%$ is van het aantal werkenden in 2014. Eerder in dit hoofdstuk is gebleken dat er een krimp in werkgelegenheid verwacht wordt bij agrarische beroepen (negatieve uitbreidingsvraag), waardoor het aantal baanopeningen volledig verklaard wordt doordat werkenden in deze sector van beroep wisselen, werkloos worden of de arbeidsmarkt verlaten (pensionering, tijdelijke uittreding van de arbeidsmarkt). Zowel in de transport- en logistiekberoepen als in de agrarische beroepen is het aandeel scholieren hoog (22\%, respectievelijk $10 \%)$. Veel van deze baanopeningen betreffen dan ook kleine bijbanen voor scholieren. De minste baanopeningen worden verwacht voor de zorg- en welzijnsberoepen $(2,2 \%)$. Zorg- en welzijnsberoepen hebben duidelijk last van de voorgenomen bezuinigingen in de sector (zie hoofdstuk 1).

TABEL 2.5 Baanopeningen naar beroepsklasse, in aantal en als percentage van de werkgelegenheid in 2014, prognose 2015-2020

\begin{tabular}{|c|c|c|c|c|}
\hline & Aantal (6 jr.) & Totaal (6 jr.) \% & Gem. jaarlijks \% & $\begin{array}{r}\text { Belang } \\
\text { vervangings- } \\
\text { vraag } \%\end{array}$ \\
\hline Pedagogische beroepen & 103.000 & 18 & 2,8 & 87 \\
\hline Creatieve en taalkundige beroepen & 43.300 & 21 & 3,3 & 73 \\
\hline Commerciële beroepen & 203.500 & 22 & 3,3 & 77 \\
\hline Bedrijfseconomische en administratieve beroepen & 306.300 & 21 & 3,2 & 65 \\
\hline Managers & 149.100 & 28 & 4,2 & 71 \\
\hline Openbaar bestuur, veiligheid en juridische beroepen & 68.700 & 25 & 3,7 & 72 \\
\hline Technische beroepen & 296.600 & 25 & 3,8 & 68 \\
\hline ICT-beroepen & 53.700 & 18 & 2,8 & 55 \\
\hline Agrarische beroepen & 73.700 & 37 & 5,4 & 100 \\
\hline Zorg- en welzijnsberoepen & 154.300 & 14 & 2,2 & 89 \\
\hline Dienstverlenende beroepen & 224.500 & 30 & 4,5 & 78 \\
\hline Transport- en logistiekberoepen & 260.200 & 46 & 6,5 & 88 \\
\hline Totaal (incl. overig) & 1.983 .900 & 24 & 3,7 & 76 \\
\hline
\end{tabular}

Bron: ROA (AIS)

Het gemiddeld aantal jaarlijkse baanopeningen voor de pedagogische beroepen is $2,8 \%$. Bij twee van de zeven beroepen ontstaan er meer baanopeningen dan het totale landelijke gemiddelde: onderwijskundigen en overige docenten $(3,9 \%)$ en sportinstructeurs $(3,8 \%)$. De minste baanopeningen zullen ontstaan bij leerkrachten van het basisonderwijs (2\%). 
Bij creatieve en taalkundige beroepen worden er meer baanopeningen verwacht dan voor de pedagogische beroepen (3,3\%), maar de jaarlijkse groei in baanopeningen ligt nog steeds onder het landelijke gemiddelde. In de onderliggende beroepsgroepen valt op dat er meer baanopeningen zullen ontstaan voor beeldende kunstenaars $(6,3 \%)$ en bibliothecarissen en conservatoren (4,7\%). Dit kan verklaard worden door het gegeven dat een groot gedeelte van de huidige werknemers in deze beroepen in de toekomst de arbeidsmarkt zullen gaan verlaten door pensionering. In deze sector zijn er weinig baanopeningen voor grafische vormgevers en productontwerpers (2\%). Eerder in dit hoofdstuk kwam al aan bod dat grafische vormgevers en productontwerpers relatief jong zijn, maar het gaat hierbij beslist niet om scholieren waardoor er geconcludeerd kan worden dat er in de toekomst minder vervanging plaatsvindt in dit beroep.

De jaarlijkse groei in baanopeningen ligt ook onder het landelijke gemiddelde bij commerciële beroepen. In beroepen van kassamedewerkers en callcentermedewerkers outbound en overige verkopers ontstaan er relatief veel baanopeningen (5,5\% en 5,1\%). Deze beroepen worden ook vaak uitgeoefend door scholieren met een bijbaantje, waardoor zij op een later moment stoppen met werken (studie of andere baan). Dit kan een verklaring bieden voor het relatief hoog aantal baanopeningen. Bij de beroepen van winkeliers, teamleiders detailhandel $(1,7 \%)$ of adviseurs marketing, public relations en sales $(1,8 \%)$ zullen in de komende 6 jaar de minste banen vrijkomen.

De meeste baanopeningen (ruim 300.000) ontstaan in bedrijfseconomische en administratieve beroepen, maar het gaat hier ook om de grootste beroepsklasse gemeten in aantal werkenden (zie hoofdstuk 1). Er wordt in slechts vier van de dertien onderliggende beroepsgroepen verwacht dat er meer baanopeningen komen dan het totale landelijke gemiddelde, namelijk bij zakelijke dienstverleners (3,9\%), directiesecretaresses (3,9\%), receptionisten en telefonisten $(4,5 \%)$ en accountants $(3,7 \%)$. Voor specialisten personeels- en loopbaanontwikkeling, een beroepsgroep die ook onderdeel uitmaakt van de bedrijfseconomische en administratieve beroepen, is het aantal baanopeningen minder hoog (2,3\%). Bij de beroepsklasse managers zijn er grote verschillen tussen het aantal baanopeningen per type manager. Zo zijn er veel baanopeningen voor bijvoorbeeld managers commerciële en persoonlijke dienstverlening (7,9\%) en ICT-managers (6,8\%), maar weinig baanopeningen voor managers van detail- en groothandel $(2 \%)$, vermoedelijk als gevolg van schaalvergroting in de handel.

In de technische beroepen zijn er relatief veel baanopeningen (3,8\% per jaar). De baanopeningen zijn bijvoorbeeld hoog voor elektriciens en elektronicamonteurs (5,9\%), maar betrekkelijk laag voor productiemachinebedieners (1,5\%). Belangrijk om op te merken is dat in de technische beroepen de baanopeningen voor $32 \%$ het gevolg zijn van uitbreidingsvraag. Ook onder ICT-beroepen is de uitbreidingsvraag verantwoordelijk voor een groot aandeel van de baanopeningen (45\%), ook al vallen de baanopeningen $(2,8 \%)$ onder het landelijke gemiddelde. 
In dienstverlenende beroepen worden baanopeningen ter hoogte van 4,5\% van het aantal werkenden in 2014 verwacht voor de jaren 2015-2020. De hoogste percentages zijn te vinden bij beroepen die veelal ook uitgeoefend worden door scholieren/studenten zoals keukenhulpen ( $7 \%$ ) en kelners en barpersoneel $(4,6 \%)$. Het minste aantal baanopeningen wordt verwacht bij beroepen als conciërges en teamleiders schoonmaak $(2,7 \%)$, kappers en schoonheidsspecialisten $(2,8 \%)$ en koks $(2,8 \%)$.

\section{Baanopeningen naar opleiding}

De totale vraag naar instromers op de arbeidsmarkt kan ook beschreven worden naar opleiding. Voor elke baanopening zijn er namelijk gediplomeerden nodig met een bepaalde opleidingsachtergrond (of een specifieke opleiding). Tabel 2.6 laat per opleidingscategorie het aantal baanopeningen en percentages van de totale werkgelegenheid in 2014 zien. Bovendien laat deze tabel zien in welke mate de baanopeningen naar opleidingscategorie veroorzaakt worden door de vervangingsvraag. Het totaal aantal baanopeningen naar opleiding wordt geschat op ruim 1,9 miljoen voor de komende 6 jaar. Van het totaal aantal baanopeningen is nagenoeg acht op de tien het gevolg van de vervangingsvraag. In de richtingen techniek en economie is het aandeel van de vervangingsvraag kleiner.

In het mbo is het percentage baanopeningen op niveau 2-3 vaak bovengemiddeld ten opzichte van het landelijk gemiddelde. Dit geldt echter niet voor de richting zorg en welzijn, waarvoor het percentage baanopeningen juist onder het landelijk gemiddelde ligt. Op mbo niveau 4 komt een ander beeld naar voren, waarin het aantal baanopeningen voor alle richtingen onder het landelijke gemiddelde ligt. Van alle opleidingsrichtingen in het mbo worden de minste baanopeningen verwacht voor zorg en welzijn op niveau $4(2,3 \%)$. De meeste baanopeningen worden verwacht voor niveau 2 en 3 van het mbo: groene opleidingen $(4,7 \%)$, techniek $(3,9 \%)$ en economie $(3,9 \%)$. Bij de opleidingsrichting economie kan dit verklaard worden door de onderliggende behoefte aan gediplomeerden van de opleidingsrichting recreatie, vrijetijd en sport.

Bij de hbo-richting onderwijs wordt verwacht dat het gemiddelde jaarlijks percentage baanopeningen op 3,9\% uitkomt, waarbij de vraag het hoogste is voor leraren algemene vakken (6,1\%). In de komende zes jaar wordt er verwacht dat hbo techniek ook meer baanopeningen heeft dan gemiddeld ( $4,3 \%$ per jaar). De onderliggende cijfers tonen aan dat de meeste baanopeningen worden verwacht voor gediplomeerden van elektrotechniek (5,9\%) en chemie (5,1\%). De opleidingscategorie 'gezondheidszorg' heeft het laagste percentage baanopeningen $(2,1 \%)$ door een lage vervangingsvraag en een lage uitbreidingsvraag. Voor hbo economie bedragen de verwachte baanopeningen $2,2 \%$ van het aantal werkenden in 2014.

In het wetenschappelijk onderwijs (wo) worden de meeste baanopeningen verwacht bij techniek (4,8\%). Het zal voornamelijk gaan om de opleidingsrichting informatica $(5,9 \%)$. Daaropvolgend worden de meeste baanopeningen bij opleidingsrichtingen van 
landbouw en natuur $(4,2 \%)$ verwacht. Binnen deze opleidingscategorie zal de vraag het grootste zijn naar gediplomeerden van natuur- en scheikunde $(4,7 \%)$.

TABEL 2.6 Baanopeningen naar opleidingscategorie, in aantal en als percentage van de werkgelegenheid in 2014, prognose 2015-2020

\begin{tabular}{|c|c|c|c|c|}
\hline & Aantal (6 jr.) & Totaal (6 jr.) \% & Gem. jaarlijks \% & $\begin{array}{r}\text { Belang } \\
\text { vervangingsvraag } \%\end{array}$ \\
\hline mbo $2 / 3$ groen & 16.700 & 32 & 4,7 & 93 \\
\hline mbo $2 / 3$ economie & 118.400 & 26 & 3,9 & 80 \\
\hline mbo 2/3 techniek & 112.800 & 25 & 3,9 & 75 \\
\hline mbo $2 / 3$ zorg en welzijn & 54.500 & 17 & 2,6 & 85 \\
\hline mbo 4 groen & 11.300 & 16 & 2,5 & 86 \\
\hline mbo 4 economie & 87.100 & 18 & 2,8 & 73 \\
\hline mbo 4 techniek & 71.900 & 20 & 3,0 & 68 \\
\hline mbo 4 zorg en welzijn & 42.600 & 14 & 2,3 & 78 \\
\hline hbo onderwijs & 57.200 & 26 & 3,9 & 94 \\
\hline hbo taal en cultuur & 24.400 & 18 & 2,8 & 65 \\
\hline hbo economie & 73.900 & 14 & 2,2 & 58 \\
\hline hbo techniek & 90.100 & 29 & 4,3 & 75 \\
\hline hbo landbouw en natuur & 14.400 & 21 & 3,3 & 87 \\
\hline hbo gezondheidszorg & 27.500 & 13 & 2,1 & 82 \\
\hline hbo gedrag en maatschappij & 41.100 & 18 & 2,9 & 86 \\
\hline wo onderwijs & 11.100 & 17 & 2,7 & 91 \\
\hline wo taal en cultuur & 29.000 & 19 & 3,0 & 75 \\
\hline wo economie en recht & 70.800 & 19 & 2,9 & 66 \\
\hline wo techniek & 47.400 & 33 & 4,8 & 78 \\
\hline wo landbouw en natuur & 20.800 & 28 & 4,2 & 90 \\
\hline wo medisch & 23.100 & 16 & 2,5 & 89 \\
\hline wo gedrag en maatschappij & 25.900 & 22 & 3,4 & 84 \\
\hline Totaal (incl. overig) & 1.921 .500 & 23 & 3,6 & 79 \\
\hline
\end{tabular}

Bron: ROA (AIS)

\subsection{Arbeidsmarktinstroom}

Tot nu toe is de vraagkant van de arbeidsmarkt aan bod gekomen. Om een gefundeerd beeld te schetsen over de arbeidsmarktperspectieven voor schoolverlaters moet ook rekening worden gehouden met de aanbodzijde. Het arbeidsmarktaanbod bestaat voor het grootste deel uit de verwachte arbeidsmarktinstroom van schoolverlaters die het initiële onderwijs verruilen voor de arbeidsmarkt. Daarnaast is er sprake van instroom op 
de arbeidsmarkt als werkenden een diploma behalen op een hoger opleidingsniveau of in een andere richting, of een combinatie van beiden..$^{83}$

In tabel 2.7 komen de prognoses aan bod van gediplomeerde schoolverlaters per opleidingscategorie die de arbeidsmarkt gaan betreden in de komende zes jaar. Naast de absolute aantallen schoolverlaters geeft deze tabel ook zicht op het aandeel schoolverlaters als percentage van de totale werkgelegenheid in 2014 (basisjaar). Voor de prognosejaren 2015-2020 worden ruim 1,6 miljoen schoolverlaters verwacht. Dit komt neer op een instroom van 3,1\% gemiddeld per jaar. De laatste kolom geeft zicht op de arbeidsmarktinstroom in de afgelopen jaren, zodat we een beeld kunnen schetsen van het veranderende aanbod van jongeren. Een vergelijking van de laatste twee kolommen laat duidelijk zien dat instroom in kwantiteit niet zal veranderen, maar wel in samenstelling: er wordt meer instroom verwacht op mbo niveau 4, hbo en wo voor de periode 20152020 dan het geval was in de afgelopen vijf jaar. De arbeidsmarktinstroom op mbo 2/3 zal juist dalen ten opzichte van de gerealiseerde instroom in de voorbije periode. Deze instroomramingen wijzen erop dat het gemiddelde opleidingsniveau van jongeren in Nederland de komende jaren verder zal stijgen.

Eerder in dit hoofdstuk is aangegeven dat zorgopleidingen op mbo-niveau relatief weinig baanopeningen zullen hebben in de prognosejaren. Dit als gevolg van een lage uitbreidingsvraag en een lage vervangingsvraag. Deze tabel laat zien dat er wel een hoge arbeidsmarktinstroom wordt verwacht van deze opleidingen (5,3\% en 4,8\%), waardoor de arbeidsmarktperspectieven van deze gediplomeerden onder druk komen te staan. Daaropvolgend hebben ook de mbo opleidingen in economische richtingen naar verwachting een hoge arbeidsmarktinstroom tot 2020 (4,8\% en 3,7\% voor mbo $2 / 3$ en mbo 4 respectievelijk), terwijl er weinig baanopeningen worden verwacht. De verhouding tussen vraag en aanbod is in dit geval ook niet in balans, waardoor de arbeidsmarktperspectieven van deze gediplomeerden minder gunstig zullen zijn in de komende jaren. De verhouding tussen vraag en aanbod is beter in balans bij de groene opleidingen (zowel op niveau 2/3 als niveau 4). Er wordt verwacht dat het aandeel gediplomeerden dat instroomt op de arbeidsmarkt ongeveer even groot is als het aantal baanopeningen in de komende prognosejaren.

In het hbo zijn er twee opleidingscategorieën met een instroom van gemiddeld jaarlijks $4 \%$ of meer. Naast opleidingen die onder taal en cultuur vallen, is dat de instroom van hbo gedrag en maatschappij. Bij beide opleidingsrichtingen wordt er verwacht dat er relatief weinig baanopeningen zullen ontstaan. Hiermee is de verhouding tussen vraag en aanbod niet voordelig voor deze gediplomeerden die de arbeidsmarkt betreden. De verwachte instroom in technische opleidingen zit duidelijk in de lift vergeleken met de afgelopen jaren. Op hbo en wo niveau (maar ook op mbo 4 niveau) wordt een grotere

83 Het arbeidsaanbod bestaat ook uit werklozen die korter dan een jaar op zoek zijn naar werk (4,1\% van het aantal werkenden in 2014, oftewel ruim 353 duizend personen), maar in dit hoofdstuk wordt alleen de instroom van schoolverlaters besproken. Bovendien wordt verondersteld dat langdurige werklozen geen concurrenten meer vormen voor schoolverlaters. Zij worden dus niet meegerekend in het arbeidsaanbod. 
jaarlijkse instroom verwacht voor de jaren 2015-2020 dan het geval was in de afgelopen vijf jaar. Toch valt de arbeidsmarktinstroom vanuit de techniek lager uit dan het totale gemiddelde. Het aantal gediplomeerden dat instroomt op de arbeidsmarkt tot 2020 wordt gemiddeld jaarlijks op 2,6\% (hbo) en 2,7\% (wo) van de werkgelegenheid in 2014 geschat. Eerder in dit hoofdstuk is er aangetoond dat er in de komende jaren baanopeningen zullen ontstaan voor afgestudeerden uit het hoger onderwijs met een technische achtergrond. In de prognosejaren wordt er verwacht dat er een discrepantie zal optreden tussen het aantal baanopeningen in de technische sector en het aantal gediplomeerden dat de arbeidsmarkt zal betreden met als gevolg dat de toekomstperspectieven van gediplomeerden met een technische achtergrond gunstig zijn (zie hoofdstuk 3).

TABEL 2.7 Instroom op de arbeidsmarkt naar opleidingscategorie, in aantal en als percentage van de werkgelegenheid in 2014, prognose 2015-2020

\begin{tabular}{|c|c|c|c|c|}
\hline & Aantal (6 jr.) & Totaal (6 jr.) \% & Gem. jaarlijks \% & $\begin{array}{r}\text { Feitelijk instroom } \\
2010-2014, \text { gem. } \\
\text { jaarlijks \% }\end{array}$ \\
\hline mbo $2 / 3$ groen & 16.000 & 30 & 4,5 & 5,2 \\
\hline mbo $2 / 3$ economie & 151.000 & 33 & 4,8 & 5,0 \\
\hline mbo $2 / 3$ techniek & 120.500 & 27 & 4,1 & 4,7 \\
\hline mbo $2 / 3$ zorg en welzijn & 120.300 & 36 & 5,3 & 5,9 \\
\hline mbo 4 groen & 10.900 & 16 & 2,4 & 2,3 \\
\hline mbo 4 economie & 117.500 & 24 & 3,7 & 3,4 \\
\hline mbo 4 techniek & 72.900 & 20 & 3,1 & 2,7 \\
\hline mbo 4 zorg en welzijn & 97.700 & 33 & 4,8 & 4,7 \\
\hline hbo onderwijs & 36.900 & 16 & 2,6 & 2,9 \\
\hline hbo taal en cultuur & 37.500 & 28 & 4,2 & 4,1 \\
\hline hbo economie & 130.800 & 24 & 3,7 & 3,6 \\
\hline hbo techniek & 52.800 & 17 & 2,6 & 2,4 \\
\hline hbo landbouw en natuur & 11.400 & 17 & 2,6 & 2,2 \\
\hline hbo gezondheidszorg & 48.200 & 23 & 3,5 & 3,2 \\
\hline hbo gedrag en maatschappij & 60.300 & 27 & 4,1 & 3,9 \\
\hline wo onderwijs & 14.900 & 23 & 3,6 & 3,4 \\
\hline wo taal en cultuur & 32.200 & 21 & 3,3 & 3,3 \\
\hline wo economie en recht & 78.400 & 21 & 3,2 & 3,2 \\
\hline wo techniek & 25.300 & 17 & 2,7 & 2,3 \\
\hline wo landbouw en natuur & 17.800 & 24 & 3,6 & 3,0 \\
\hline wo medisch & 33.300 & 23 & 3,5 & 3,4 \\
\hline wo gedrag en maatschappij & 25.200 & 22 & 3,3 & 3,4 \\
\hline Totaal (incl. overig) & 1.651 .200 & 20 & 3,1 & 3,1 \\
\hline
\end{tabular}

Bron: ROA (AIS) 
In OESO-landen is de internationale mobiliteit van studenten sterk toegenomen in de afgelopen drie decennia: het aantal studenten dat in een ander land studeert (studiemigranten) is toegenomen van 0,8 miljoen in 1975 naar 4,3 miljoen in 2011 (OECD (2013), Education at a Glance 2013: OECD Indicators, $0 E(D$, Paris). In een recent gepubliceerd rapport laten wij aan de hand van een overzicht van de literatuur zien dat studiemigratie gezien kan worden als een potentiële bron van gekwalificeerde arbeidskrachten, en dat veel landen inspanningen verrichten om studiemigranten aan te trekken (Fouarge, D. \& M. Özer (2014), International mobility of students - Its impact on labour market forecasts and its contribution to the Dutch economy, ROA, Maastricht: ROA-TR-2014/6). Of landen met veel studiemigranten daar profijt van hebben hangt af van de mate waarin buitenlandse studenten na het behalen van hun diploma in het land blijven waar zijn hun onderwijs hebben genoten. De schaarse literatuur over het behoud van studiemigranten rapporteert schattingen van de blijfkans (of retentiegraad) variërend van $19 \%$ tot $43 \%$.

In de afgelopen tien jaar is zowel het aantal buitenlandse studenten in Nederland als de internationale mobiliteit van Nederlandse studenten toegenomen. Echter, de mate van studiemobiliteit varieert sterk tussen de diverse vakgebieden: het is vooral hoog in gebieden zoals economie en natuurwetenschappen. Over mogelijke verschillen in blijfkans op de Nederlandse arbeidsmarkt naar vakgebied is echter niets bekend. $00 k$ is het onbekend in welke mate de blijfkans met de conjunctuur mee varieert.

In de instroomprognoses van het ROA worden studiemigranten meegeteld bij de instroom op de Nederlandse arbeidsmarkt. De ratio hierachter is dat Nederlandse werkgevers daadwerkelijk kunnen putten uit dit potentieel arbeidsaanbod als zij op zoek zijn naar gekwalificeerd personeel. CBS becijferde onlangs dat de blijfkansen van internationaal afgestudeerden uit 2008/2009 38\% is, gemeten 5 jaar na afstuderen; Nuffic (2015), Analyse stayrate van internationaal afgestudeerden: 2008-09. Toch is de gevoeligheid van studiemigratie op de prognoses nooit getest. In het rapport over studiemigratie is de omvang van studiemigratie per studierichting gekwantificeerd. Daarbij is een aantal aannames gemaakt met betrekking tot de blijfkans van studiemigranten, en is nagegaan wat de gevolgen zijn van het tellen van studiemigratie bij de instroom voor de perspectieven naar opleiding (ITA). Het wel of niet tellen van studiemigratie heeft invloed op de omvang van de instroomprognoses, zeker in de richting landbouw en natuur en economie die veel buitenlandse studenten trekken. Het meetellen van studiemigratie is nauwelijks van invloed op de arbeidsmarktperspectieven naar opleidingen die geen substantieel aantal buitenlandse studenten trekken. Voor wo opleidingen in de economie/econometrie worden de perspectieven beter (uitgaand van de oude prognoses tot 2018) als buitenlandse studenten bij de instroom niet worden meegeteld. Dit geld ook voor hbo opleidingen in de richtingen landbouw en natuur en fysiotherapie. Telkens is er sprake van een verschuiving van een positie in de ITA typering.

\subsection{Conclusie}

De werkgelegenheid zal naar verwachting groeien met gemiddeld jaarlijks $0,8 \%$ tot 2020. In slechts één van de twaalf beroepsklassen wordt een krimp in werkgelegenheid verwacht, namelijk bij de agrarische beroepen. Het aantal werkenden in de agrarische beroepen zal de komende zes jaar naar verwachting met gemiddeld o,6\% per 
jaar krimpen. In alle onderliggende beroepen is deze krimp zichtbaar (hulpkrachten landbouw, hoveniers, tuinders en kwekers, veetelers en land- en bosbouwers). In de ICT-beroepen en technische beroepen zal de werkgelegenheid het sterkst toenemen (beide een jaarlijks gemiddelde van 1,2\%). De verwachte groei voor technische beroepen wordt teruggevonden bij de uitbreidingsvraag over alle opleidingsniveaus, namelijk bij mbo techniek, hbo techniek en wo techniek.

Een andere belangrijke vraagcomponent in het prognosemodel is de vervangingsvraag. De vervangingsvraag is de vraag naar nieuwe arbeidskrachten als gevolg van het vrijkomen van bestaande arbeidsplaatsen. In de prognoseperiode 2015-2020 moeten in totaal ruim 1,5 miljoen arbeidskrachten vervangen worden, omdat zij van beroep wisselen of de arbeidsmarkt (tijdelijk of permanent) verlaten om bijvoorbeeld met (vervroegd) pensioen te gaan. Ten opzichte van het werkgelegenheidsniveau in 2014 komt dit neer op een gemiddelde jaarlijkse vervangingsvraag naar beroep van $2,9 \%$. Van alle beroepsklassen is de vervangingsvraag naar verwachting het hoogst voor de transport- en logistiekberoepen en de agrarische beroepen. Dit in tegenstelling tot de lage vervangingsvraag naar werkenden in ICT-beroepen en zorg- en welzijnsberoepen. De vervangingsvraag naar opleiding omvat ook de vervangingsbehoefte als gevolg van doorleren, maar telt beroepsveranderingen niet mee. De prognoses voor de vervangingsvraag naar opleiding laten zien dat tot 2020 gemiddeld jaarlijks 2,9\% van het totaal aantal werkenden vervangen moet worden. De mbo 4 opleidingscategorieën hebben een lagere vervangingsvraag dan de vergelijkbare mbo 2/3 opleidingscategorieën. De vervangingsvraag naar hbo opleidingscategorieën loopt behoorlijk uiteen: voor de opleidingscategorieën hbo onderwijs en techniek dienen naar verwachting relatief veel werkenden in de komende 6 jaar vervangen te worden, terwijl er relatief weinig werkenden met een hbo economie opleiding in de komende jaren vervangen dienen te worden. Ook de vervangingsvraag voor wo opleidingscategorieën loopt uiteen van $2 \%$ (wo economie en recht) tot 3,9\% (wo techniek).

In de periode 2015-2020 zullen er volgens de prognoses bijna 2 miljoen baanopeningen ontstaan. Ruim 7 op de 10 baanopeningen ontstaan als gevolg van vervangingsvraag, terwijl het overige deel bestaat uit uitbreidingsvraag. In de informaticaberoepen heeft de uitbreidingsvraag juist een relatief groot aandeel (45\%) in de baanopeningen. Het aantal baanopeningen zal het meest toenemen bij de transport- en logistiekberoepen en in de agrarische sector. Een belangrijke kanttekening hierbij is dat het grote aantal baanopeningen het gevolg is van een groot aantal scholieren in deze beroepsklassen. Op alle opleidingsniveaus ontstaan veel baanopeningen voor arbeidskrachten met een diploma in de techniek, maar er worden juist weinig baanopeningen verwacht voor opleidingen die gericht zijn op zorg en welzijn. Dat laatste is het gevolg van zowel een lage uitbreidingsvraag en een lage vervangingsvraag. Vooral de lage uitbreidingsvraag staat in schril contrast met de ROA-prognoses van twee jaar geleden, maar laat duidelijk zien dat de voorgenomen bezuinigingen in de zorg- en welzijnssector grote gevolgen hebben voor de baanperspectieven. 
Het aanbod in de periode 2015-2020 bestaat uit ruim 1,6 miljoen schoolverlaters die instromen op de arbeidsmarkt. ${ }^{84}$ Dit betekent een gemiddelde jaarlijkse instroom van 3,1\% van de werkgelegenheid in 2014. Er zal in de komende jaren relatief veel arbeidsmarktinstroom zijn voor zorgopleidingen in het beroepsonderwijs, terwijl er juist weinig baanopeningen verwacht worden. De instroom van schoolverlaters met een diploma in de richting economie is op de meeste opleidingsniveaus relatief groot. Hoewel de instroom vanuit technische opleidingen naar verwachting zal stijgen ten opzichte van de afgelopen jaren valt deze lager uit dan het aantal baanopeningen in de techniek. De instroom op de arbeidsmarkt laat verder zien dat het gemiddelde opleidingsniveaus in Nederland de komende jaren verder zal stijgen.

84 Het aanbod bestaat daarnaast uit 353.000 kortdurig werklozen. 


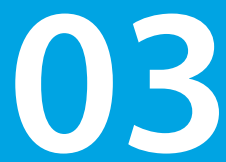

\section{AANSLUITING TUSSEN ONDERWIJS EN ARBEIDSMARKT}

\subsection{Inleiding}

In dit hoofdstuk wordt aandacht besteed aan de huidige aansluiting tussen onderwijs en arbeidsmarkt voor recent afgestudeerden en aan de arbeidsmarktperspectieven naar beroep en opleiding voor de periode 2015-2020. Paragraaf 3.2 schetst de actuele aansluiting tussen onderwijs en arbeidsmarkt voor schoolverlaters in 2014. Voor de verschillende opleidingscategorieën wordt nagegaan in hoeverre gediplomeerden erin geslaagd zijn een baan te vinden. Daarnaast wordt gekeken naar aanvullende aansluitingsfactoren voor de werkende schoolverlaters. Naast het vinden van werk geven zaken als beloning, het werkzaam zijn in een 'kleine baan' (minder dan 12 uur per week) en de mate van onderbenutting immers een indicatie van de verhouding tussen de actuele vraag naar arbeidskrachten en het aanbod van de (recent gediplomeerde) beroepsbevolking. De arbeidsmarktsituatie van schoolverlaters naar opleidingsachtergrond in 2014 wordt afgezet tegen de cijfers van 2010 om recente ontwikkelingen zichtbaar te maken.

In paragraaf 3.3 worden de verwachte ontwikkelingen aangaande de arbeidsmarktpositie van schoolverlaters besproken. Hierbij wordt aandacht besteed aan de toekomstperspectieven voor schoolverlaters in de prognoseperiode 2015-2020 naar opleidingscategorieën. Deze toekomstperspectieven worden afgeleid van de confrontatie tussen de verwachte vraag- en aanbodontwikkelingen op de arbeidsmarkt, die in hoofdstuk 2 aan bod zijn gekomen. Deze vraag-en aanbodontwikkelingen beïnvloeden niet alleen de toekomstperspectieven van schoolverlaters, maar ook de verwachte knelpunten in de personeelsvoorziening voor werkgevers. Om die reden wordt in paragraaf 3.4 dieper ingegaan op de verwachte knelpunten naar beroep in de periode tot 2020.

\subsection{Aansluiting onderwijs-arbeidsmarkt van recent afgestudeerden}

In deze paragraaf worden de aansluitingsproblemen tussen onderwijs en arbeidsmarkt besproken voor recent gediplomeerden. Dit zijn jongeren die in het school-/academisch jaar 2012/2013 hun diploma hebben behaald en eind 2014 geënquêteerd zijn, ongeveer anderhalf jaar na het afronden van hun opleiding. De cijfers die worden gepresenteerd 
betreffen enkel schoolverlaters die zich aanbieden op de arbeidsmarkt. ${ }^{85}$ Dit kunnen dus ook schoolverlaters zijn die een vervolgopleiding volgen en daarnaast eventueel een bijbaan hebben. Voor de gepresenteerde resultaten wordt gebruik gemaakt van schoolverlatersgegevens afkomstig van het SchoolverlatersInformatieSysteem (SIS) van het ROA. ${ }^{86}$ Voor de verschillende opleidingscategorieën wordt de kwaliteit van de aansluiting tussen het onderwijs en de arbeidsmarkt gemeten door werkloosheid, het bruto maandloon, het werken onder het eigen opleidingsniveau of buiten de opleidingsrichting en het aantal contracturen (kleine banen of deeltijdbanen). De indicatoren hebben dus voor een groot deel betrekking op de kans op werk in het verlengde van de opleiding of het (tijdig) vinden van een baan op niveau. De meest recente gegevens worden vergeleken met de gegevens van schoolverlaters uit 2010. Dit zijn jongeren die in het schooljaar 2008/2009 hun diploma hebben behaald. ${ }^{87}$

\section{Werkloosheid}

Tabel 3.1 geeft per opleidingscategorie de gemiddelde werkloosheidspercentages van recent afgestudeerden. De werkloosheidspercentages voor 2014 worden afgezet tegen die uit 2010. Daarnaast wordt het verschil tussen beide jaren weergegeven, uitgedrukt in procentpunten.

In 2014 was afgerond 9 procent van de jongeren die hun diploma haalden in 20122013 werkloos. Tot deze groep werklozen worden gediplomeerden gerekend die geen betaald werk hebben, daarvoor wel direct beschikbaar zijn en recent naar betaald werk hebben gezocht. Het uitblijven van (sterke) economische groei na de crisis van 2008 heeft ervoor gezorgd dat het aantal jongeren dat zich aanbiedt op de arbeidsmarkt ruim hoger ligt dan het aantal vacatures voor starters. Daarnaast is het mogelijk dat vraag en aanbod in kwalitatieve zin eveneens niet goed op elkaar aansluiten. De vacatures die zijn ontstaan voorzien niet in gelijke kansen op de arbeidsmarkt voor gediplomeerden, omdat niet naar alle opleidingsprofielen (evenveel) vraag is. Deze 'scheefheid' uit zich in aanzienlijke verschillen in werkloosheidspercentages naar opleidingsachtergrond. Zo is het werkloosheidspercentage onder schoolverlaters van het middelbaar onderwijs

85 Het behalen van een diploma is voor veel schoolverlaters en gediplomeerden geen eindstation: een aanzienlijk deel, dat sterk verschilt tussen opleidingsniveaus, studeert door (ROA (2015). Schoolverlaters tussen onderwijs en arbeidsmarkt 2014. ROA-R-2015/3). Van alle mbo schoolverlaters biedt $71 \%$ zich aan op de arbeidsmarkt (dit betreft zowel BOL- als BBL-opleidingen), terwijl $85 \%$ van de afgestudeerde hbo'ers op zoek is naar betaald werk. Dit percentage ligt lager bij vmbo'ers $(28 \%)$ en havo/vwo'ers (19\%). Wel hebben veel jongeren een kleine (bij)baan. Schoolverlaters die aangeven dat hun situatie op het meetmoment het beste kan worden omschreven als 'studie' - en eventueel wel een (bij-)baan hebben - worden hier niet toe gerekend.

86 Meer informatie over de transitie van school naar werk van recent gediplomeerden is te vinden in ROA (2015), Schoolverlaters tussen onderwijs en arbeidsmarkt 2014, ROA-R-2015/3, Maastricht: ROA. Gedetailleerde gegevens uit het schoolverlatersonderzoek van het ROA is te vinden in de online applicatie van het SchoolverlatersInformatieSysteem: http://roastatistics.maastrichtuniversity.nl/.

87 De in deze paragraaf gepresenteerde cijfers voor afgestudeerden van het wo hebben betrekking op 2013 (in plaats van 2014 voor mbo en hbo) en op 2009 (in plaats van 2010 voor mbo en hbo), tenzij anders weergegeven. Dit zijn gediplomeerden van het schooljaar 2011/2012 en 2007/2008. Dit komt doordat de afgestudeerdenenquête voor het wo, in tegenstelling tot de andere enquêtes, slechts om het jaar wordt gehouden. 
relatief laag voor wat betreft havo/vwo gediplomeerden $(5,0 \%)$ en hoog voor vmbogediplomeerden (10,7\%).

Wanneer we kijken naar twee uitersten, observeren we aan de ene kant een relatief laag werkloosheidspercentage van 3,9 voor gediplomeerden van mbo-opleidingen in de techniek op niveau 4. Daar tegenover staat een zeer fors werkloosheidspercentage van 16,5 voor afgestudeerden van wo-opleidingen taal en cultuur. Deze vergelijking laat zien dat er veel variatie bestaat in werkloosheidspercentages van recent gediplomeerden wanneer opgesplitst wordt naar het niveau en de richting van de gevolgde opleiding. Hoewel er verschillen bestaan tussen de opleidingsniveaus zijn deze relatief klein (een maximale afwijking van 3,8\%-punt van het gemiddelde) in vergelijking tot de verschillen tussen richtingen binnen de opleidingsniveaus. Voor de gediplomeerden van mboopleidingen op niveau 2 of 3 zijn degenen die een technische richting volgden het minst vaak werkloos, met een werkloosheidspercentage van 5,8\%. Ook gediplomeerden uit de richtingen groen en zorg en welzijn hebben een werkloosheidspercentage dat lager is dan gemiddeld voor het mbo $2 / 3$. Zoals hierboven al werd geconstateerd, hebben de schoolverlaters van een mbo $2 / 3$ opleidingen in economische richtingen de slechtste aansluiting op de arbeidsmarkt in termen van werkloosheid. Voor hen geldt dat bijna één op de zes gediplomeerden werkloos is. Onder gediplomeerden van mbo-opleidingen op niveau 4 ligt de werkloosheid over het algemeen lager. Dit geldt ook voor de afzonderlijke onderwijsrichtingen, met uitzondering van groen. Mbo-gediplomeerden van groene opleidingen zijn iets vaker werkloos wanneer zij een opleiding op niveau 4 hebben genoten $(8,0 \%)$ dan wanneer zij een opleiding volgden op niveau 2 of $3(7,2 \%)$.

Het werkloosheidspercentage van de totale groep gediplomeerden van het hbo is ietwat lager dan dat voor mbo 4-gediplomeerden. De werkloosheidspercentages van de onderwijsrichtingen binnen het hbo liggen daarnaast dichter bij elkaar dan het geval is binnen het mbo, maar de verschillen zijn desondanks noemenswaardig. De groep gediplomeerden van hbo-opleidingen in de gezondheidszorg heeft het laagste werkloosheidspercentage $(4,4 \%)$. Voor hbo onderwijs en hbo techniek ligt het werkloosheidspercentage eveneens onder het gemiddelde voor hbo-gediplomeerden (in beide gevallen 5,9\%). Voor de opleidingen in de richtingen landbouw en natuur en gedrag en maatschappij ligt het werkloosheidspercentage daarentegen juist hoger dan voor alle schoolverlaters samen. Van alle hbo-gediplomeerden hebben zij de grootste kans om anderhalf jaar na afstuderen werkloos te zijn.

Met 10,4\% ligt de werkloosheid onder afgestudeerden van het wo in 2014 ruim twee keer zo hoog als vijf jaar daarvoor. Afgaande op dit werkloosheidspercentage hebben wo'ers na vmbo-gediplomeerden de slechtste aansluiting met de arbeidsmarkt. Voor vier van de zeven onderscheiden opleidingscategorieën in het wetenschappelijk onderwijs ligt de werkloosheid van recent gediplomeerden hoger dan het gemiddelde van alle gediplomeerden samen (inclusief jongeren die enkel het middelbaar onderwijs hebben afgerond). Een mogelijke verklaring voor de relatief hoge werkloosheid onder wo-afgestudeerden is dat hoogopgeleiden langer zoeken naar een geschikte baan. Bovendien 
geldt dat de langere termijnperspectieven op de arbeidsmarkt doorgaans beter zijn voor hoog- dan voor laagopgeleiden.

TABEL 3.1 Werkloosheidspercentage van gediplomeerde schoolverlaters en mutatie 2010 en 2014, naar opleidingscategorie ${ }^{88}$

\begin{tabular}{|c|c|c|c|}
\hline & $2010 \%$ & $2014 \%$ & Mutatie in \%-punten \\
\hline vmbo & 6,2 & 10,7 & 4,5 \\
\hline havo/vwo & 3,7 & 5,0 & 1,3 \\
\hline mbo $2 / 3$ groen & 1,8 & 7,2 & 5,4 \\
\hline mbo $2 / 3$ economie & 8,0 & 16,2 & 8,2 \\
\hline mbo $2 / 3$ techniek & 3,2 & 5,8 & 2,6 \\
\hline mbo 2/3 zorg en welzijn & 2,5 & 7,6 & 5,1 \\
\hline mbo $2 / 3$ totaal & 4,3 & 9,6 & 5,3 \\
\hline mbo 4 groen & 4,0 & 8,0 & 4,0 \\
\hline mbo 4 economie & 4,9 & 11,9 & 7,0 \\
\hline mbo 4 techniek & 3,5 & 3,9 & 0,4 \\
\hline mbo 4 zorg en welzijn & 1,4 & 6,6 & 5,2 \\
\hline mbo 4 totaal & 3,0 & 7,8 & 4,8 \\
\hline hbo onderwijs & 4,0 & 5,9 & 1,9 \\
\hline hbo taal en cultuur & 7,5 & 7,9 & 0,4 \\
\hline hbo economie & 6,6 & 8,3 & 1,7 \\
\hline hbo techniek & 4,2 & 5,9 & 1,7 \\
\hline hbo landbouw en natuur & 8,3 & 9,3 & 1,0 \\
\hline hbo gezondheidszorg & 2,0 & 4,4 & 2,4 \\
\hline hbo gedrag en maatschappij & 5,5 & 9,9 & 4,4 \\
\hline hbo totaal & 5,2 & 7,2 & 2,0 \\
\hline wo onderwijs & 3,5 & 9,0 & 5,5 \\
\hline wo taal en cultuur & 7,8 & 16,5 & 8,7 \\
\hline wo economie en recht & 6,4 & 10,4 & 4,0 \\
\hline wo techniek & 4,2 & 5,4 & 1,2 \\
\hline wo landbouw en natuur & 4,6 & 8,4 & 3,8 \\
\hline wo medisch & 2,1 & 6,2 & 4,1 \\
\hline wo gedrag en maatschappij & 7,4 & 14,7 & 7,3 \\
\hline wo totaal & 5,4 & 10,4 & 5,0 \\
\hline Totaal (incl. overig) & 4,7 & 8,8 & 4,1 \\
\hline
\end{tabular}

Bron: ROA (AIS)

Afgestudeerden van universitaire opleidingen binnen de richting taal en cultuur zijn het vaakst werkloos $(16,5 \%)$, gevolgd door afgestudeerden met een wo diploma in de rich-

88 Naast de 24 opleidingscategorieën die worden onderscheiden is voor ieder opleidingsniveau (mbo en hoger) een categorie 'totaal' opgenomen. Omdat de classificatie van opleidingen die voor het project onderwijs arbeidsmarkt (POA) gehanteerd wordt afwijkt van de classificatie die doorgaans wordt gebruikt in de rapportages waarin schoolverlatersgegevens (SIS-data) worden gebruikt, is het mogelijk dat de cijfers in dit hoofdstuk niet overeenkomen met cijfers uit andere rapportages die de ROA-schoolverlatersonderzoeken betreffen. Zo vallen schoolverlaters van mbo-niveau-1-opleidingen in deze tabel onder vmbo-schoolverlaters, terwijl deze in de SIS-rapportages buiten beschouwing blijven. 
ting gedrag en maatschappij $(14,76 \%)$. Het werkloosheidspercentage voor wo gediplomeerden economie en recht is gelijk aan het gemiddelde voor alle wo-gediplomeerden samen (10,4\%). Afgestudeerden van technische universitaire opleidingen zijn beduidend minder vaak werkloos $(5,4 \%)$ en ook voor medisch opgeleide wo'ers ligt het werkloosheidspercentage relatief laag (6,2\%).

Ten opzichte van 2010 is de werkloosheid binnen alle opleidingscategorieën toegenomen. Voor enkele opleidingscategorieën is deze verandering echter zeer gering, zoals voor mbo 4 techniek en hbo taal en cultuur. De werkloosheid nam in deze categorieën 'slechts' met minder dan een half procentpunt toe. Voor de overige opleidingscategorieën lag de werkloosheid in 2014 in verschillende gevallen ongeveer dubbel zo hoog als in 2010. Voor enkele opleidingscategorieën ( $m b o$ 2/3 groen, mbo 2/3 welzijn, mbo 4 zorg en welzijn en wo medisch) lag het werkloosheidspercentage onder gediplomeerden zelfs drie tot vier keer hoger in 2014. Het is echter belangrijk om op te merken dat de jeugdwerkloosheid de laatste twee jaar afneemt, hoewel erg langzaam (zie hoofdstuk 1).

\section{Beloning}

De beloning van werkende gediplomeerden is een belangrijke indicator van het rendement van verschillende opleidingen op de arbeidsmarkt. Het loon geeft een indicatie van de waarde die werkgevers toekennen aan de kwalificaties van recent afgestudeerden. De waarde van een diploma op de arbeidsmarkt is voor een belangrijk deel afhankelijk van de vraag- en aanbodverhoudingen op de arbeidsmarkt. In de huidige ruime arbeidsmarkt hebben werkgevers over het algemeen een ruime keuze bij het aannemen van personeel, wat zich kan uiten in dalende lonen voor jonge arbeidsmarktintreders die er wel in geslaagd zijn om een baan te vinden. In tabel 3.2 wordt het gemiddelde bruto maandloon van de recent gediplomeerde werkenden gepresenteerd per opleidingscategorie, waarbij is gecorrigeerd voor het aantal arbeidsuren per week. ${ }^{89,90}$

Gemiddeld genomen verdienen schoolverlaters bij een voltijds betrekking $€ 1.813$ bruto per maand. Dat is een daling van gemiddeld 5\% per jaar ten opzichte van 2010. Deze daling van de lonen heeft zich binnen alle opleidingscategorieën voorgedaan, al varieert de omvang van de daling per opleidingsniveau en richting. ${ }^{91}$ Het verdient vermelding dat de lonen in tabel 3.2 niet zijn gecorrigeerd voor leeftijd. Er bestaat doorgaans een positieve correlatie tussen leeftijd en beloning, niet alleen vanwege het minimumjeugdloon waar de gemiddelde schoolverlaters van vmbo, havo/vwo en mbo gediplomeerde schoolverlaters onder vallen, maar ook vanwege (door werkgevers veronder-

89 Werkenden: Jongeren die aangeven niet te studeren en die betaald werk verrichten. Voor een deel kan het gaan om jongeren die na afstuderen aan een duale opleiding zijn begonnen (bijvoorbeeld een MBO-BBL opleiding), en hun leerwerkplek niet als studie, maar als werk beschouwen. Het maandloon is omgerekend naar een voltijdsequivalent, en de gemiddelde jaarlijkse groei is de groei van het reëel loon, dus na correctie voor inflatie.

90 In hoofdstuk 1 is, per beroepsgroep, het uurloon van recent gediplomeerden in SIS vergeleken met het uurloon van alle werkenden in EBB.

91 Het feit dat de lonen binnen alle opleidingscategorieën daalden illustreert de sterke negatieve impact van de recente economische crisis op de arbeidsmarktpositie van schoolverlaters. 
stelde) grotere competenties en productiviteit bij schoolverlaters die ouder zijn. Dat het gemiddelde bruto uurloon in tabel 3.2 doorgaans stijgt met het opleidingsniveau heeft dan ook deels met de hogere gemiddelde leeftijd van hoger opgeleiden en deels met de hogere productiviteit van hoger opgeleiden te maken.

TABEL 3.2 Bruto maandloon van werkzame schoolverlaters en de gemiddelde jaarlijkse mutatie tussen 2010 en 2014, naar opleidingscategorie

\begin{tabular}{|c|c|c|}
\hline & $2014 €$ & Gem. jaarlijks \% \\
\hline vmbo & 890 & -6 \\
\hline havo/vwo & 1.030 & -6 \\
\hline mbo $2 / 3$ groen & 1.497 & -5 \\
\hline mbo $2 / 3$ economie & 1.417 & -7 \\
\hline mbo $2 / 3$ techniek & 1.810 & -5 \\
\hline mbo $2 / 3$ zorg en welzijn & 1.835 & -5 \\
\hline mbo $2 / 3$ totaal & 1.687 & -6 \\
\hline mbo 4 groen & 1.582 & -7 \\
\hline mbo 4 economie & 1.573 & -6 \\
\hline mbo 4 techniek & 1.884 & -7 \\
\hline mbo 4 zorg en welzijn & 2.001 & -6 \\
\hline mbo 4 totaal & 1.818 & -7 \\
\hline hbo onderwijs & 2.367 & -4 \\
\hline hbo taal en cultuur & 1.867 & -5 \\
\hline hbo economie & 2.229 & -4 \\
\hline hbo techniek & 2.373 & -6 \\
\hline hbo landbouw en natuur & 2.187 & -5 \\
\hline hbo gezondheidszorg & 2.479 & -5 \\
\hline hbo gedrag en maatschappij & 2.174 & -6 \\
\hline hbo totaal & 2.251 & -5 \\
\hline wo onderwijs & 2.721 & -2 \\
\hline wo taal en cultuur & 2.394 & -3 \\
\hline wo economie en recht & 2.663 & -3 \\
\hline wo techniek & 2.675 & -2 \\
\hline wo landbouw en natuur & 2.528 & -1 \\
\hline wo medisch & 2.898 & -1 \\
\hline wo gedrag en maatschappij & 2.409 & -4 \\
\hline wo totaal & 2.623 & -2 \\
\hline Totaal (incl. overig) & 1.813 & -5 \\
\hline
\end{tabular}

Bron: ROA (AIS)

Binnen de verschillende opleidingsniveaus variëren de gemiddelde reële lonen aanzienlijk per opleidingsrichting. Voor alle niveaus geldt dat gediplomeerden van een opleiding uit de opleidingscategorie zorg en welzijn (of medisch voor wat betreft het wo) gemiddeld genomen het hoogste bruto maandloon hebben. Gediplomeerden van het mbo (niveaus $2 \mathrm{t} / \mathrm{m} 4$ ) in de richting techniek hebben het één na hoogste reële loon. Voor de opleidingscategorieën groen en economie liggen de lonen aanzienlijk lager. 
Voor alle richtingen geldt dat gediplomeerden van opleidingen op niveau 4 een hoger bruto maandinkomen hebben dan gediplomeerden van de lagere niveaus. Voor niveau 4 was de daling van de lonen echter sterker dan voor gediplomeerden van de lagere niveaus.

De lonen voor gediplomeerden van het hbo liggen het hoogst voor degenen die een opleiding in de gezondheidszorg hebben gevolgd. Ook voor gediplomeerden van hbo techniek en hbo onderwijs liggen de gemiddelde bruto maandlonen relatief hoog, dat wil zeggen: in vergelijking tot het gemiddelde loon van afgestudeerden van het hbo. Hbo gediplomeerden van een opleiding in taal en cultuur hebben met afstand het laagste maandloon, ongeveer gelijk aan het gemiddelde loon voor mbo 4 gediplomeerden. Ook voor wo liggen de lonen het laagst onder groep afgestudeerden in de richting taal en cultuur. Het loon van afgestudeerden wo gedrag en maatschappij ligt slechts een fractie hoger. De hoogste lonen vinden we voor afgestudeerden wo medisch en wo onderwijs. Daarnaast is de daling van de lonen voor wo afgestudeerden kleiner dan voor de lagere opleidingsniveaus. Het lijkt er dus op dat de economische malaise van de afgelopen jaren voor wo'ers vooral tot uiting is gekomen in een stijgende werkloosheid, en minder in dalende lonen.

\section{Aansluiting: werk op niveau en eigen richting}

Lage werkloosheid onder schoolverlaters duidt in eerste instantie op een goede aansluiting tussen onderwijs en arbeidsmarkt. Het is echter mogelijk dat een deel van de schoolverlaters werk heeft dat niet aansluit bij de gevolgde opleiding, voor wat betreft het niveau, de richting of beide. Dit kan werken als 'uitwijkmechanisme', waarbij het accepteren van werk onder het niveau of buiten de eigen richting een alternatief is op werkloosheid. ${ }^{22}$

Als schoolverlaters een baan hebben die qua niveau lager is dan hun opleidingsniveau wordt gesproken over onderbenutting. Hierbij wordt het door de werkgever minimaal vereiste niveau voor de functie vergeleken met het opleidingsniveau van de werkzame schoolverlater. Tabel 3.3 laat voor alle afzonderlijke opleidingscategorieën zien welk deel van de werkzame schoolverlaters in 2014 onder zijn of haar niveau werkt. Tevens wordt de procentuele verandering weergegeven ten opzichte van 2010. In de derde kolom is per opleidingscategorie het aandeel werkzame schoolverlaters gegeven met een baan buiten het eigen vakgebied in 2014, en de verandering ten opzichte van 2010 in de laatste kolom.

Gemiddeld genomen is voor gediplomeerden van alle opleidingsniveaus zowel de kans om onder het eigen opleidingsniveau te werken als de kans om buiten de eigen rich-

92 Het kan echter ook duiden op een feitelijk verschil tussen de werkelijke capaciteiten van iemand en zijn of haar behaalde diploma (zie bijvoorbeeld Coenen, J. F. Cörvers, D. Fouarge, C. Meng \& A. Nelen (2009), Onderbenutting van mbo'ers nuttig op de arbeidsmarkt?, TPEdigitaal 3(3): 103-123). 
ting te werken toegenomen tussen 2010 en 2014. Deze toename is het sterkst voor gediplomeerde schoolverlaters van het vmbo, waarvan het aandeel dat onder het niveau werkt met 22 procentpunten is toegenomen en het aandeel dat in een andere richting werkzaam is dan de gevolgde opleiding met 17 procentpunten. Hiermee is het vmbo de opleidingscategorie met de slechtste aansluiting op de arbeidsmarkt, zowel in kwantitatieve zin (werkloosheid) als in kwalitatieve zin (onderbenutting en het werken buiten de eigen richting). Onder schoolverlaters van $\mathrm{mbo} 2 / 3$ werken degenen uit economische richtingen het vaakst onder hun niveau (46\%). Bovendien ligt dit aandeel flink hoger dan in 2010 (stijging van 9,5 procentpunt). Het aandeel dat buiten de eigen richting werkt nam daarentegen af (naar $41,9 \%$ in 2014). Gediplomeerden van zorg en welzijn richtingen zijn juist het minst vaak 'onderbenut' $(24,8 \%)$ van alle mbo $2 / 3$ gediplomeerden. Dit aandeel heeft relatief gezien wel de grootste stijging doorgemaakt; in 2010 werkte nog slechts $15,7 \%$ van de schoolverlaters van mbo zorg en welzijn $2 / 3$ onder het eigen niveau.

Gediplomeerden van mbo-opleidingen op niveau 4 werken anderhalf jaar na schoolverlaten minder vaak onder hun niveau en buiten de eigen richting dan gediplomeerden van opleidingen op niveau 2 of 3 . Het aandeel 'onderbenut' is voor mbo 4 gemiddeld genomen zelfs lager dan voor alle andere opleidingsniveaus (23,6\%). Dit is hoofdzakelijk toe te schrijven aan de zeer lage percentages voor mbo 4 zorg en welzijn. Van gediplomeerden van deze opleidingen werkt slechts 13 procent onder het eigen niveau, en heeft 17,3 procent een baan die qua richting niet (geheel) aansluit bij de gevolgde opleiding. Voorts verschillen de opleidingscategorieën groen, economie en techniek niet veel van elkaar in het aandeel 'onderbenut', maar wel in het aandeel gediplomeerden met een horizontale mismatch. Gediplomeerden van economische opleidingen werken het vaakst buiten de eigen richting (42,3\%), gevolgd door gediplomeerden van groene opleidingen $(34,2 \%)$ en technische opleidingen $(29,4 \%)$.

Voor het hoger onderwijs stellen we vast dat gediplomeerden van de opleidingscategorie hbo onderwijs het minst vaak onder hun niveau aan de slag gaan $(13,2 \%)$. Ook voor hbo-gediplomeerden van technische opleidingen ligt dit aandeel relatief laag (15,2\%). Hiertegenover staan de afgestudeerden van hbo gedrag en maatschappij, welke in meer dan de helft van de gevallen (52,3\%) een baan hebben waarvoor een hbo diploma niet vereist is. Zij werken echter wel vaker binnen de eigen richting dan afgestudeerden van hbo taal en cultuur en hbo economie. Bijna vier op de tien gediplomeerden van deze richtingen werken buiten de richting van de opleiding die zij volgden.

Ook voor het wo ligt het aandeel afgestudeerden met een horizontale of verticale mismatch bovengemiddeld hoog voor gedrag en maatschappij. De hoogste percentages op onderbenutting en het werken buiten de eigen richting zijn echter voor wo taal en cultuur (respectievelijk 50,9\% en 41,9\%). Van alle wo'ers hebben degenen met een medisch achtergrond de meest nauwe aansluiting met de arbeidsmarkt. Desondanks werkt 15,5 procent onder wo-niveau en heeft 12,6 procent een baan in een andere richting dan de gevolgde opleiding. 
TABEL 3.3 Percentage onderbenutting bij werkzame schoolverlaters en mutatie tussen 2010 en 2014, naar opleidingscategorie

\begin{tabular}{|c|c|c|c|c|}
\hline & \multicolumn{2}{|c|}{ Onderbenutting } & \multicolumn{2}{|c|}{ Buiten eigen/verwante richting } \\
\hline & 2014 & Mutatie in \%-punten & 2014 & Mutatie in \%-punten \\
\hline vmbo & 38,4 & 22,4 & 57,3 & 16,6 \\
\hline havo/vwo & 61,0 & 5,7 & - & - \\
\hline mbo $2 / 3$ groen & 35,2 & 4,6 & 36,0 & 0,1 \\
\hline mbo $2 / 3$ economie & 46,0 & 9,5 & 41,9 & $-2,3$ \\
\hline mbo 2/3 techniek & 32,8 & $-3,4$ & 29,6 & $-1,3$ \\
\hline mbo $2 / 3$ zorg en welzijn & 24,8 & 9,1 & 19,2 & 3,6 \\
\hline mbo $2 / 3$ totaal & 34,2 & 4,8 & 30,1 & 0,1 \\
\hline mbo 4 groen & 29,4 & $-1,5$ & 34,2 & 2,2 \\
\hline mbo 4 economie & 31,4 & 10,0 & 42,3 & 4,9 \\
\hline mbo 4 techniek & 29,8 & 6,5 & 29,4 & 1,6 \\
\hline mbo 4 zorg en welzijn & 13,0 & 4,8 & 17,3 & 4,2 \\
\hline mbo 4 totaal & 23,6 & 8,1 & 29,4 & 6,0 \\
\hline hbo onderwijs & 13,2 & 5,6 & 12,5 & 6,2 \\
\hline hbo taal en cultuur & 27,5 & 5,4 & 38,8 & 2,9 \\
\hline hbo economie & 26,3 & 1,8 & 36,5 & 1,1 \\
\hline hbo techniek & 15,2 & $-0,6$ & 18,6 & 3,8 \\
\hline hbo landbouw en natuur & 28,7 & 5,1 & 27,6 & 2,1 \\
\hline hbo gezondheidszorg & 21,2 & 3,2 & 11,3 & 4,8 \\
\hline hbo gedrag en maatschappij & 52,3 & 14,4 & 29,3 & 17,2 \\
\hline hbo totaal & 26,0 & 5,0 & 26,2 & 5,6 \\
\hline wo onderwijs & 36,2 & $-3,3$ & 12,8 & 0,3 \\
\hline wo taal en cultuur & 50,9 & $-2,8$ & 41,9 & $-1,3$ \\
\hline wo economie en recht & 39,8 & 5,1 & 31,7 & $-0,4$ \\
\hline wo techniek & 29,4 & $-6,5$ & 20,7 & $-1,0$ \\
\hline wo landbouw en natuur & 24,8 & $-6,5$ & 19,5 & 2,7 \\
\hline wo medisch & 15,5 & 5,0 & 12,6 & $-1,2$ \\
\hline wo gedrag en maatschappij & 43,4 & 9,3 & 39,4 & 10,2 \\
\hline wo totaal & 35,0 & 1,7 & 27,5 & 0,8 \\
\hline Totaal (incl. overig) & 33,3 & 7,9 & 29,5 & 1,2 \\
\hline
\end{tabular}

Bron: ROA (AIS) 


\section{Deeltijdwerk en kleine banen}

Vanaf het tweede kwartaal van 2014 is het aantal banen van werknemers en zelfstandigen in Nederland gestegen. ${ }^{93}$ Vooral jongeren lijken weer werk te vinden. Tegelijkertijd daalde de hoeveelheid werk echter licht, wat betekent dat het gemiddelde aantal arbeidsuren per week is afgenomen. Deze ontwikkeling ligt ten grondslag aan de waargenomen banengroei. ${ }^{94}$ Figuur 3.1 laat zien in hoeverre het aandeel werkenden met een kleine baan (minder dan 12 uur per week) in verschillende leeftijdsgroepen is veranderd in de afgelopen jaren. Hierbij zijn grote verschillen te observeren tussen de werkenden in de leeftijdscategorie 15-25 enerzijds en werkenden in de leeftijdscategorieën 25-45 en 45-75 anderzijds. Voor de groep 15-25 jarigen, waar het aandeel werkenden met een kleine baan in alle jaren flink hoger ligt dan voor de andere leeftijdscategorieën, neemt het aandeel werkenden met minder dan 12 arbeidsuren per week al sinds 2007 vrijwel constant toe. Voor werkenden uit de andere leeftijdsgroepen is dit aandeel min of meer constant gebleven in de periode 2007-2014. Werken in kleine banen kan het gevolg zijn van wensen van werkgevers (bijvoorbeeld voor het opvangen van pieken in de productie), ${ }^{95}$ werkenden (bijvoorbeeld scholieren met een bijbaantje) of beide. Het gaat echter doorgaans om banen waar nauwelijks een bestaanszekerheid op kan worden gebouwd.

93 CBS (2015), Werkgelegenheid trekt aan, webmagazine 13 februari 2015 (geraadpleegd op 21-08-2015: http:// www.cbs.nl/nl-NL/menu/themas/arbeid-sociale-zekerheid/publicaties/artikelen/archief/2015/werkgelegenheid-trekt-aan.htm)

94 Voor de gevolgen van de invoering van de nieuwe berekeningswijze van de beroepsbevolking op de werkloosheidscijfers en overige aansluitingskenmerken van recent gediplomeerden. Zie ROA (2015), Schoolverlaters tussen onderwijs en arbeidsmarkt 2014 (ROA-R-2015/3),. Maastricht: Researchcentrum voor Onderwijs en Arbeidsmarkt. Voor veranderingen in de omvang en samenstelling van de beroepsbevolking die optreden als gevolg van de nieuwe definitie van de beroepsbevolking, zie Ineke Bijlsma, Sander Dijksman, Didier Fouarge, Annemarie Künn-Nelen, Davey Poulissen (2015), Veranderingen in de omvang en samenstelling van de beroepsbevolking als gevolg van de overstap op de ILO-definitie van de beroepsbevolking, Maastricht: ROA-TR-2015/6.

95 Künn-Nelen, A., A. De Grip \& D. Fouarge (2013), Is Part-Time Employment Beneficial for Firm Productivity?, Industrial and Labor Relations Review, 66(5): 1172-1191. 
FIGUUR 3.1 Aandeel werkenden met een kleine baan (<12 uur per week), naar leeftijdsgroep, 2007-

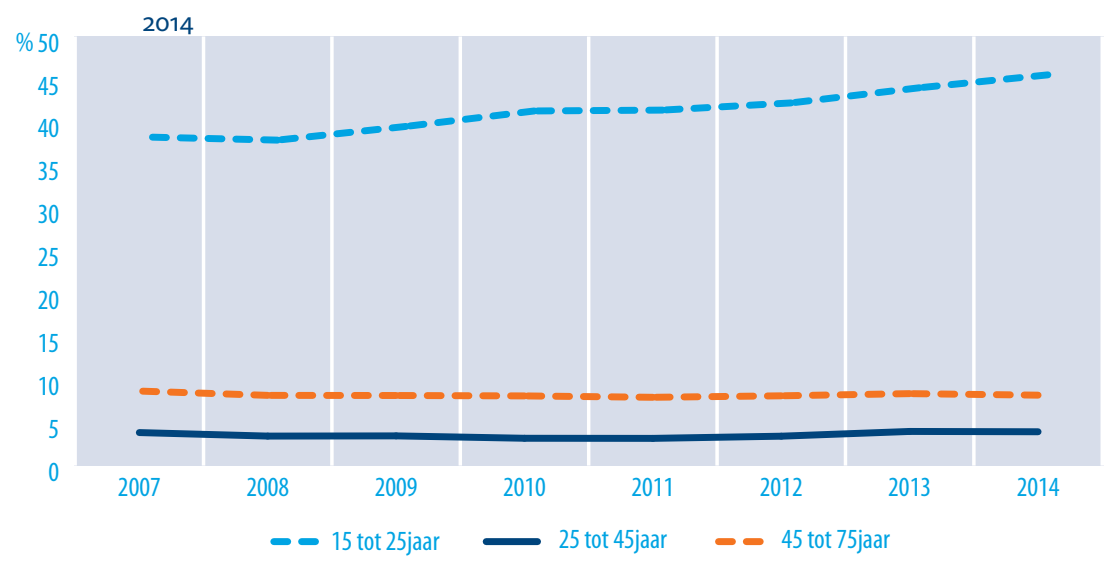

Bron: Enquête beroepsbevolking (EBB) via CBS statline ${ }^{96}$

De ontwikkeling in kleine banen zoals hierboven geschetst, is eveneens zichtbaar in de schoolverlatersgegevens (SIS). In tabel 3.4 is voor de verschillende opleidingscategorieën het percentage recent gediplomeerden dat in deeltijd werkt weergegeven, waarbij twee categorieën van elkaar onderscheiden worden: de gediplomeerden die minder dan 12 uur werken ('kleine banen') en de gediplomeerden die 12 tot 20 uur werken. Het aandeel werkenden in kleine banen, uitgedrukt als percentage van de totale groep gediplomeerde schoolverlaters, ligt met 10,3\% (tabel 3.4) aanzienlijk lager dan de $26 \%$ in figuur 3.1. Dit komt waarschijnlijk (deels) doordat de percentages in figuur 3.1 betrekking hebben op alle werkenden - dus inclusief mensen die enkel basisonderwijs hebben gevolgd - terwijl SIS enkel recent gediplomeerden van het voorbereidend middelbaar onderwijs of hoger bevraagt. Daarnaast blijven de jongeren die nu nog in het onderwijs zitten en een bijbaan hebben (bijvoorbeeld als vakkenvuller) deels buiten beschouwing in tabel 3.4, doordat het hier enkel gediplomeerden betreft waarvan 'werk' naar eigen zeggen hun belangrijkste activiteit was. In de EBB worden deze jongeren met bijbanen wel allemaal onder de werkenden geschaard. Het percentage recent gediplomeerde werkenden met een kleine baan is in de periode 2010-2014 met afgerond 4 procentpunt gestegen. Voor de deeltijdcategorie 12 tot 20 uur is het aandeel ook toegenomen, maar relatief minder sterk dan het aandeel kleine banen. De hoogste percentages vinden we terug voor havisten en vwo'ers. Van de havo/vwo schoolverlaters met een baan is bijna de helft minder dan 12 uur werkzaam. Voor gediplomeerden van het vmbo is dit afgerond 29 procent.

Voor recent gediplomeerden van mbo- en hbo-opleidingen ligt het aandeel met een kleine baan aanzienlijk lager en is de mutatie van dit percentage ten opzichte van 2010 minder groot, met uitzondering van het hbo, waar het aandeel kleine banen bijna verdubbelde. Mbo-gediplomeerden zorg en welzijn werken het vaakst minder dan 12

96 CBS Statline: http://statline.cbs.nl/Statweb/publication/?DM $=S L N L \& P A=82309$ ned $\& D 1=20 \& D_{2}=0 \& D_{3}=1 \& D_{4}$ $=0 \& D_{5}=55-61 \& S T B=G_{1}, G_{2}, G_{3}, T, G 4 \& V W=T$ 
uur. Ook voor hbo'ers uit deze richting ligt het aandeel met een kleine baan relatief hoog, maar er wordt een nog groter aandeel geobserveerd voor gediplomeerden van opleidingen in gedrag en maatschappij. De gediplomeerden van opleidingen in de richtingen groen en techniek hebben het minst vaak een kleine baan. Wo'ers werken slechts in heel weinig gevallen minder dan 12 uur (1,6\%).

TABEL 3.4 Percentage schoolverlaters met een kleine baan (<12 uur, 12-20 uur), naar opleidingscategorie, en mutatie tussen 2010 en 2014

\begin{tabular}{|c|c|c|c|c|}
\hline & $<12$ & & $12-2 c$ & \\
\hline & 2014 & Mutatie in $\%$-punten & 2014 & Mutatie in \%-punten \\
\hline vmbo & 28,9 & 15,8 & 18,1 & 8,8 \\
\hline havo/vwo & 47,9 & 10,4 & 27,0 & 0,2 \\
\hline mbo $2 / 3$ groen & 6,2 & 3,5 & 3,4 & 1,6 \\
\hline mbo $2 / 3$ economie & 6,0 & 0,7 & 9,9 & 5,0 \\
\hline mbo $2 / 3$ techniek & 0,3 & $-0,8$ & 1,8 & 1,4 \\
\hline mbo 2/3 zorg en welzijn & 6,7 & 2,2 & 16,0 & 4,7 \\
\hline mbo $2 / 3$ totaal & 4,2 & 0,7 & 8,6 & 3,4 \\
\hline mbo 4 groen & 3,6 & $-1,4$ & 8,7 & 3,1 \\
\hline mbo 4 economie & 4,9 & $-0,5$ & 10,5 & 3,5 \\
\hline mbo 4 techniek & 5,2 & 0,4 & 3,1 & $-1,5$ \\
\hline mbo 4 zorg en welzijn & 7,0 & 2,2 & 9,4 & 0,8 \\
\hline mbo 4 totaal & 5,7 & 0,8 & 8,5 & 1,3 \\
\hline hbo onderwijs & 6,5 & 3,1 & 12,7 & 6,6 \\
\hline hbo taal en cultuur & 3,9 & $-0,2$ & 5,5 & 0,5 \\
\hline hbo economie & 2,0 & 0,9 & 2,8 & 0,3 \\
\hline hbo techniek & 1,3 & $-0,5$ & 1,6 & 0,4 \\
\hline hbo landbouw en natuur & 4,4 & 3,5 & 2,6 & 2,3 \\
\hline hbo gezondheidszorg & 6,6 & 3,6 & 11,0 & 2,8 \\
\hline hbo gedrag en maatschappij & 8,6 & 5,2 & 11,7 & 4,1 \\
\hline hbo totaal & 4,2 & 1,8 & 6,5 & 2,1 \\
\hline wo onderwijs & 3,7 & 3,5 & 9,7 & 3,4 \\
\hline wo taal en cultuur & 3,4 & 2,6 & 6,4 & 3,2 \\
\hline wo economie en recht & 1,0 & 0,8 & 1,4 & 0,7 \\
\hline wo techniek & 1,0 & 0,8 & 0,9 & 0,8 \\
\hline wo landbouw en natuur & 0,9 & 0,6 & 0,9 & $-0,7$ \\
\hline wo medisch & 0,4 & 0,0 & 1,8 & 0,2 \\
\hline wo gedrag en maatschappij & 2,0 & 0,5 & 5,5 & 0,3 \\
\hline wo totaal & 1,6 & 1,1 & 3,2 & 1,0 \\
\hline Totaal (incl. overig) & 10,3 & 3,7 & 9,9 & 3,1 \\
\hline
\end{tabular}

Bron: ROA (AIS) 


\section{Combinatie van verschillende dimensies}

Om een totaal beeld te krijgen van de aansluiting van recent gediplomeerden, zijn de hierboven besproken indicatoren in onderstaande figuren samengebracht. Voor vier verschillende opleidingsniveaus ( $\mathrm{mbo} 2 / 3, \mathrm{mbo} 4$, hbo en wo) zijn vijf kernindicatoren voor de arbeidsmarktaansluiting bijeengebracht in één spindiagram, waarbij voor iedere opleidingsrichting de gestandaardiseerde Z-score op de betreffende dimensie is af te lezen. Wanneer de lijn van een opleidingsrichting op de nullijn van het web ligt, houdt dit in dat de score van een opleidingsrichting op de betreffende indicator overeenkomt met de gemiddelde score op die indicator van alle gediplomeerden met hetzelfde opleidingsniveau. Voor alle indicatoren geldt dat hoe dichter de score van een opleidingscategorie tegen de kern van het spindiagram ligt, des te beter de aansluiting van de gediplomeerden op de arbeidsmarkt is. Een score die eerder aan de uiteinden van de spijlen ligt duidt op een minder goede aansluiting. Hierbij wordt gemakshalve aangenomen dat recent gediplomeerden op zoek zijn naar een baan voor meer dan 20 uur in de week, hoewel dit natuurlijk niet altijd zo is.

Figuur 3.2 geeft voor gediplomeerden van mbo 2/3 opleidingen per opleidingscategorie de scores op de verschillende aansluitingsdimensies. De lijn van zorg en welzijn springt het meest in het oog: op drie van de vijf dimensies hebben gediplomeerden van deze opleidingscategorie de beste scores van alle categorieën (dat wil zeggen ten opzichte van mbo $2 / 3$ opleidingen uit andere onderwijsrichtingen) terwijl de opleidingscategorie op de dimensie 'werk voor minder dan 20 uur' juist het hoogst scoort, hierbij gezien als indicatie voor een slechte aansluiting. Gediplomeerden van mbo 2/3 opleidingen zorg en welzijn hebben in vergelijking tot alle mbo $2 / 3$ gediplomeerden bij elkaar genomen, een kleine kans om werkloos te zijn anderhalf jaar na afstuderen. Ook hebben zij een kleine kans op onderbenutting of een baan buiten de richting van het behaalde diploma en verdienen zij minder vaak, dan gediplomeerden van andere richtingen, minder dan het gemiddelde loon. De overige opleidingsrichtingen op mbo niveau 2/3 lijken meer op elkaar voor wat betreft de samenhang van aansluitingsindicatoren, waarbij gediplomeerden van de richting techniek na zorg en welzijn de beste scores hebben en gediplomeerden van de richting economie gemiddeld genomen het slechtst scoren. De laatstgenoemde groep heeft op vier van de vijf indicatoren de slechtste score, waarvan de hoge werkloosheid het meest in het oog springt. Dit duidt op een 'overaanbod' van mbo $2 / 3$ gediplomeerden in economische richtingen. 
FIGUUR 3.2 Combinatie van aansluitingsindicatoren, gediplomeerden mbo 2/3-opleidingen

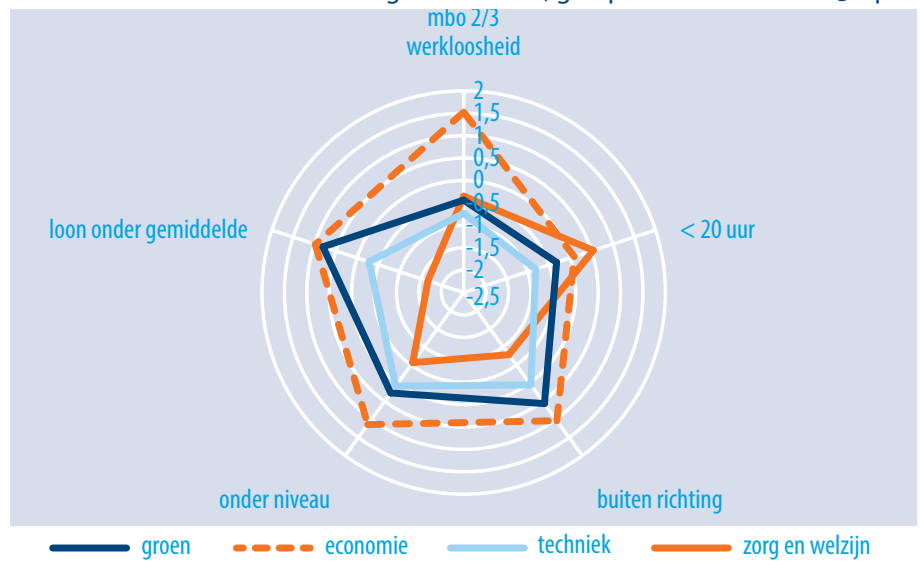

Bron: ROA (AIS)

In figuur 3.3 liggen de lijnen voor zorg en welzijn en voor techniek wederom het dichtst bij de kern van het web, waarmee dit ook voor niveau 4 de richtingen met de beste arbeidsmarktaansluiting in 2014 zijn. Zoals bij gediplomeerden van mbo 2/3 geldt ook hier voor wat betreft zorg en welzijn de uitzondering van de indicator $\%$ minder dan 20 uur werkzaam,' waarop deze richting juist het slechtst scoort van alle onderwijsrichtingen. Verder liggen de lijnen van de verschillende opleidingsrichtingen - zorg en welzijn uitgezonderd - voor mbo niveau 4 dichter bij elkaar dan voor mbo niveau 2/3. Op basis hiervan kan worden gesteld dat de kwaliteit van arbeidsmarktaansluiting voor gediplomeerden mbo 4 minder sterk verschilt tussen de richtingen groen, techniek en economie dan voor gediplomeerden van niveau 2 en 3. Op de indicator 'onderbenutting' hebben deze drie onderwijsrichtingen zelfs een gelijke score. Voor het werken buiten de richting en het aandeel met een beneden gemiddeld loon zijn de verschillen groter. 
FIGUUR 3.3 Combinatie van aansluitingsindicatoren, gediplomeerden mbo 4-opleidingen

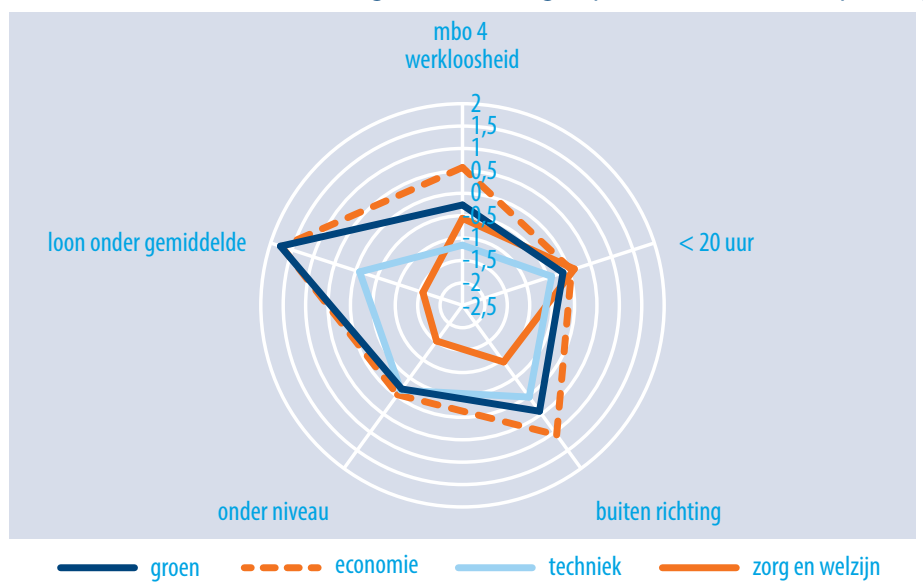

Bron: ROA (AIS)

Onder hbo afgestudeerden is de aansluiting onderwijs-arbeidsmarkt - uitgaande van de vijf indicatoren - het best voor gediplomeerden uit de richtingen techniek en gezondheidszorg (figuur 3.4). Ook gediplomeerden uit hbo onderwijs scoren over het algemeen goed, met uitzondering van het aandeel dat minder dan 20 uur werkzaam is. Gediplomeerden uit de gezondheidszorg hebben gemiddeld genomen minder vaak een 'horizontale mismatch' dan gediplomeerden uit alle overige onderwijsrichtingen. Gediplomeerden van opleidingen binnen gedrag en maatschappij ervaren - alles bij elkaar genomen - de slechtste aansluiting op de arbeidsmarkt. Op drie van de vijf indicatoren (werkloosheid, werk onder niveau en minder dan 20 uur werkend) scoren zij het slechtst van alle richtingen. Deze richtingen buiten beschouwing gelaten, kan worden gesteld dat de spreiding van arbeidsmarktuitkomsten tussen richtingen in het hbo kleiner is dan op alle andere opleidingsniveaus. Met andere woorden is de kwaliteit van de arbeidsmarktaansluiting voor gediplomeerden van het hoger onderwijs minder sterk afhankelijk van de gevolgde richting dan voor gediplomeerden van andere opleidingsniveaus.

Ook voor het wo verschilt de kwaliteit van aansluiting op de arbeidsmarkt voor de verschillende onderwijsrichtingen (figuur 3.5). De samenhang tussen de scores op de verschillende dimensies blijkt echter voor alle richtingen ongeveer gelijk - de richtingen onderwijs en medisch uitgezonderd. Gediplomeerden uit de richting onderwijs scoren bovengemiddeld goed op de indicatoren werkloosheid, verticale mismatch en het aandeel met een beneden gemiddeld loon en tegelijkertijd bovengemiddeld slecht op de twee overige factoren, met name op het aandeel dat minder dan 20 uur werkt. Gediplomeerden van wo opleidingen in de richtingen medisch, techniek en landbouw en natuur, scoren goed op vrijwel alle aansluitingsindicatoren. De uitzondering hierop is de loonindicator voor afgestudeerden van een opleiding binnen landbouw en natuur. 
FIGUUR 3.4 Combinatie van aansluitingsindicatoren, gediplomeerden hbo-opleidingen

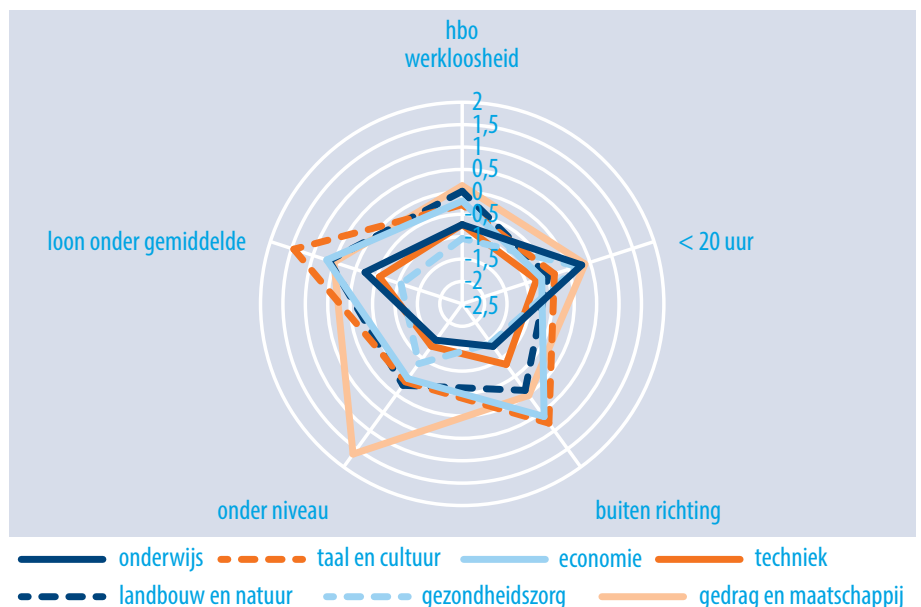

Bron: ROA (AIS)

FIGUUR 3.5 Combinatie van aansluitingsindicatoren, gediplomeerden wo-opleidingen

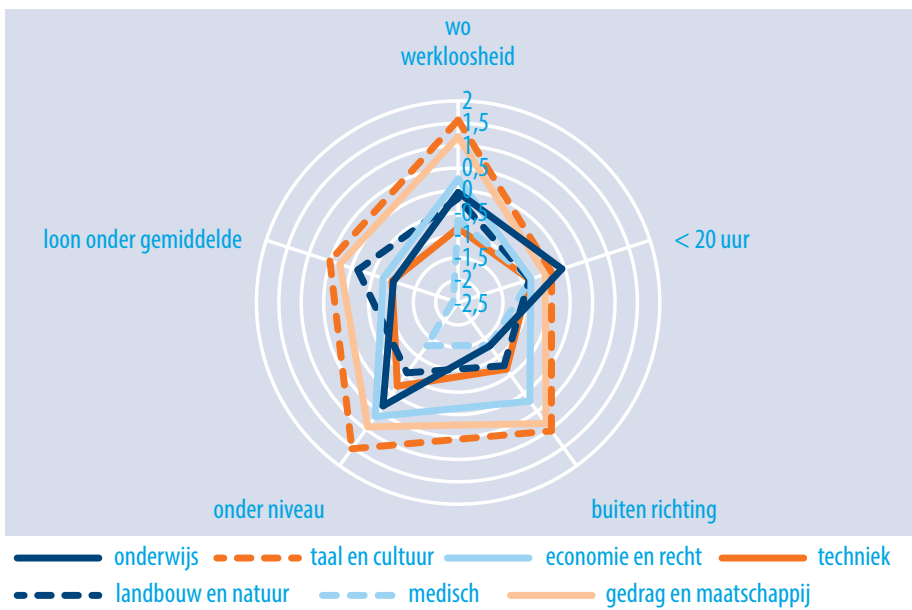

Bron: ROA (AIS)

\subsection{Toekomstige arbeidsmarktperspectieven naar opleiding}

De arbeidsmarktperspectieven naar opleiding - de Indicator Toekomstig Arbeidsmarktperspectief (ITA) - worden bepaald aan de hand van een confrontatie tussen aanbod van arbeid (kortdurig werklozen en verwachte arbeidsmarktinstroom) 
en vraag naar arbeid (verwachte baanopeningen en substitutievraag).97 De arbeidsmarktperspectieven voor jongeren die in de periode 2015-2020 de arbeidsmarkt zullen betreden zijn gemiddeld genomen over alle opleidingscategorieën redelijk (zie tabel 3.5). Hiermee lijken de zwaarste klappen van de economische crisis achter de rug te zijn. De arbeidsmarktperspectieven zijn echter lang niet voor alle schoolverlaters rooskleurig. Waar in de afgelopen jaren nog geringe verschillen in werkloosheid bestonden tussen de opleidingsniveaus (zie bijvoorbeeld tabel 3.1), kunnen op basis van de scores op de ITA relatief grote verschillen in arbeidsmarktkansen binnen de niveaus worden verwacht voor de komende zes jaar. Een grove waarneming leidt tot de conclusie dat de perspectieven slecht tot redelijk zijn voor gediplomeerden van beroepsopleidingen op middelbaar niveau, en beter worden naarmate het opleidingsniveau hoger ligt. De ITA's lijken niet noemenswaardig te verschillen voor gediplomeerden van beroepsopleidingen op niveau $2 / 3$ enerzijds en op niveau 4 anderzijds. Toch zijn de perspectieven wel degelijk beter voor mbo 4 gediplomeerden dan voor mbo $2 / 3$ gediplomeerden. Voor $19 \%$ van de mbo 4 gediplomeerden zijn de perspectieven goed tot zeer goed. Op mbo $2 / 3$ niveau is dit het geval voor slechts $3 \%$ van de gediplomeerden.

Voor gediplomeerden van middelbare beroepsopleidingen zijn de arbeidsmarktperspectieven gemengd, maar slechts voor één opleidingscategorie goed (mbo 4 groen). Waar de perspectieven van gediplomeerden uit de onderwijsrichting techniek nog op zijn minst redelijk zijn (dit geldt ook voor mbo 2/3 groen en wijst op een klein 'aanbodoverschot'), hebben schoolverlaters van economische beroepsopleidingen matige perspectieven en zijn de vooruitzichten voor zorg en welzijn getypeerd als slecht. De verwachte hoge instroom voor deze opleidingscategorieën ligt hieraan ten grondslag. De sombere vooruitzichten voor gediplomeerden van zorgopleidingen zien we overigens voor alle opleidingsniveaus terug, met de ITA-typering matig voor hbo gezondheidszorg en wo medisch. Hier zijn natuurlijk ook uitzonderingen op, zoals voor wo (dier)geneeskunde en tandheelkunde waar de perspectieven redelijk zijn met een klein 'aanbodoverschot' van 3\%. Het moge duidelijk zijn: de perspectieven naar opleidingscategorie verbergen een grote diversiteit in perspectieven naar opleidingstype.

97 Omdat er nauwelijks sprake is van negatieve uitbreidingsvraag naar opleiding zijn de ITA en de ITKP (Indicator Toekomstige Knelpunten in de Personeelsvoorziening) vrijwel gelijk aan elkaar. De ITKP wordt dan ook in dit rapport niet besproken. 
De beperkte arbeidsmarktperspectieven voor jongeren met een diploma in de zorg staan vrijwel haaks op de relatief lage werkloosheidspercentages onder schoolverlaters van zorgopleidingen in 2014 (zie tabel 3.1). Toen profiteerden gediplomeerden van opleidingen in de richting zorg en welzijn mogelijk nog van de ruim duizend banen die de sector er extra bij kreeg tussen 2008 en 2012 (zie UWV sectorbeschrijving zorg, 2015). In de verpleging, verzorging en thuiszorg ontstonden destijds veel baanopeningen nadat de particuliere sector sterk gekrompen was vanwege de crisis. Deze banenmotor is inmiddels echter aan het haperen. Voor de gehele periode wordt uitgegaan van bescheiden groei van de werkgelegenheid van slechts $0,2 \%$ per jaar in de zorgsector en $0,3 \%$ in de welzijnssector (was $2,7 \%$ en 2,3\% per jaar in de periode 1996-2014, zie tabel 1.3). Stijgende eigen bijdragen en eigen risico's, druk op budgetten vanuit gemeenten, zorgverzekeraars en bezuinigingen door de overheid zorgen ervoor dat delen van de zorg met krimp te maken zullen krijgen, zeker in de eerste komende jaren. Deze krimp zal naar verwachting plaatsvinden in de verpleging, verzorging en thuiszorg, waardoor de vraag naar mbo-gediplomeerden van zorgopleidingen gering zal zijn, terwijl de instroom hoog blijft en de arbeidsmarktperspectieven als gevolg daarvan slecht. Andere delen van de zorg - zoals de eerste lijn groeien daarentegen licht waardoor de hoge instroom daar een minder groot probleem is. Dit verklaart waarom de perspectieven voor afgestudeerden van zorgopleidingen op de hogere opleidingsniveaus iets gunstiger zijn dan voor het middelbaar beroepsonderwijs. In de jaren vanaf 2017 is er echter weer sprake van een voorzichtige banengroei hetgeen tot betere perspectieven zou kunnen leiden tegen het einde van de prognoseperiode.

Voor mbo-gediplomeerden uit technische opleidingen zijn de perspectieven beter dan voor zorg en welzijn, maar niet zonder uitzondering. Voor gediplomeerden van mbo $2 / 3$ opleidingen in de richting techniek zullen bovengemiddeld veel banen ontstaan. Echter, doordat de instroom vanuit deze opleidingen eveneens hoog ligt, levert dit voor bijvoorbeeld mbo $2 / 3$ voertuigtechniek matige perspectieven op. De vraag-aanbod verhouding resulteert voor overige opleidingstypen in de techniek in redelijke perspectieven.

Voor jongeren die een technische beroepsopleiding op niveau 4 voltooiden zijn de arbeidsmarktperspectieven gemiddeld genomen beter dan voor gediplomeerden van de lagere niveaus. Binnen deze opleidingscategorie zijn veel opleidingsclusters te vinden waarvoor de perspectieven goed zijn. Dit geldt bijvoorbeeld voor mbo 4 werktuigbouwkunde en metaalbewerking, mbo 4 technische installatie en mbo 4 bouw en infra. Deze opleidingen profiteren duidelijk van de verwachte groei in de bouw sector. Slechte perspectieven in de techniek zijn er ook: bijvoorbeeld voor mbo 4 media en vormgeving en mbo 4 transport en logistiek, in beide gevallen als gevolg van een bovengemiddeld hoge instroom tot 2020 .

Ook voor gediplomeerden van groene opleidingen lijkt doorleren te lonen. Naast de redelijke perspectieven voor gediplomeerden van mbo groen op niveau 2/3 staan goede vooruitzichten voor arbeidsmarktinstromers vanuit mbo 4 voedsel, natuur en milieu. 
Er bestaan aanzienlijke verschillen in de arbeidsmarktperspectieven van hbo-gediplomeerden uit de onderscheiden opleidingsrichtingen. Zo zijn voor drie van de zeven opleidingscategorieën goede kansen op de arbeidsmarkt voorzien (onderwijs, techniek en landbouw en natuur), maar voor de overige drie richtingen juist matige perspectieven (taal en cultuur, economie en gezondheidszorg). Voor lerarenopleidingen zijn de perspectieven over het algemeen goed (zie ook tekstbox 3.2). In de technische richting en in de landbouw en natuur zullen naar verwachting veel baanopeningen ontstaan in de periode tot 2020. Doordat de verwachte instroom voor deze opleidingen ondanks de geraamde stijging relatief laag ligt, zullen zij over het algemeen zonder veel moeite aan het werk komen. De arbeidsmarktperspectieven voor hbo gezondheidszorg zijn zoals eerder beschreven matig (dit geldt zowel voor hbo verpleegkunde en medische diagnostiek als voor hbo fysiotherapie). Dit is toe te schrijven aan een relatief laag aantal baanopeningen gecombineerd met een relatief hoge instroom vanuit de onderliggende opleidingen tot 2020 .

Ook voor de hbo richting gedag en maatschappij worden matige perspectieven voorzien, welke hoofdzakelijk resulteren uit het grote aantal gediplomeerden uit deze opleidingscategorie dat zich zal aanbieden op de arbeidsmarkt (deze opleidingscategorie heeft een van de hoogste instroom cijfers van alle hbo-opleidingen, zie hoofdstuk 2), en ook de hoogste werkloosheidspercentage van alle hbo-opleidingen (zie tabel 3.1). Binnen deze opleidingscategorie hebben gediplomeerden van hbo pedagogiek nog de meeste kans op werk. Zij hebben redelijke perspectieven die hoofdzakelijk toe te schrijven zijn aan de bovengemiddelde vervangingsvraag.

Voor hbo economie en hbo taal en cultuur zijn de perspectieven tot 2020 matig. Voor hbo-gediplomeerden van economische opleidingen komt dit hoofzakelijk voort uit een lage vervangingsvraag en geringe werkgelegenheidsgroei. Een uitzondering hierop is hbo accountancy en financiën, waarvoor de vervangingsvraag niet ver onder het gemiddelde ligt en er redelijke kansen op de arbeidsmarkt worden verwacht. Vanuit opleidingen binnen hbo taal en cultuur zal naar verwachting een hoog aantal gediplomeerden de arbeidsmarkt betreden, wat in combinatie met een gering aantal baanopeningen zal resulteren in matige perspectieven. 
De arbeidsmarkt voor leraren kenmerkt zich door de geslotenheid: alleen degenen met een eersteof tweedegraads diploma voor een bepaald vak zijn bevoegd om les te geven in dit vak. Op scholen in het primair onderwijs worden vrijwel alle lessen gegeven door bevoegde leraren, dat wil zeggen degenen die een PABO-diploma hebben (hbo basisonderwijs). Voor de jaren tot 2020 wordt er een ontoereikend aanbod van afgestudeerden van de $\mathrm{PABO}$ verwacht, vooral vanwege de daling van het aantal PABO-studenten die samenhangt met de invoering van entree- en kennisbasistoetsen. Ondanks dat daalt de werkgelegenheid voor leraren basisonderwijs in veel regio's door de afname van het aantal leerlingen. De eerste tekenen van een toenemende schaarste zijn de terugval in de werkloosheid van gediplomeerden een jaar na afstuderen. Eind 2013 was de werkloosheid onder deze afgestudeerden van hbo onderwijs nog bijna 11\%, eind 2014 is de werkloosheid gedaald tot minder dan 7\%. 00k de overige aansluitingsindicatoren voor PABO-afgestudeerden lijken over het algemeen te zijn verbeterd (gegevens hbo-monitor). Er blijven echter regionale verschillen in de discrepanties. Deze verschillen zijn onder meer afhankelijk van de toestroom van asielkinderen op basisscholen in bepaalde regio's, maar ook van de bereidheid van leraren om les te geven in andere regio's door te pendelen of te verhuizen.

In het voorgezet onderwijs is het beeld meer divers. De spanning op de arbeidsmarkt loopt in de komende periode op voor hbo-leraren die zijn afgestudeerd in zowel algemene als beroepsgerichte vakken. Volgens de cijfers van de hbo-monitor is de werkloosheid onder afgestudeerde leraren in talen en exacte vakken de laatste jaren laag (ROA/SIS). Naar verwachting zal dit de komende jaren zo blijven. De vervangingsvraag is door de uitstroom van oudere leraren hoger dan gemiddeld, de uitbreidingsvraag is lager dan gemiddeld door de afname van het aantal leerlingen in het voortgezet en middelbaar beroepsonderwijs. Voor onderwijsassistenten van mbo-niveau zijn de arbeidsmarktperspectieven slecht, voor afgestudeerde leraren met een academische graad over algemeen matig. $0 \mathrm{p}$ basis van de raming van CentERdata kan worden geconcludeerd dat er met name grote verschillen zijn tussen de vakken (CentERdata (2015), De toekomstige arbeidsmarkt voor onderwijspersoneel po, vo en mbo 20152025, Update oktober, Tilburg). De vacatures zullen naar verwachting het moeilijkst te vervullen zijn voor Duits, natuurkunde en scheikunde. 0ok voor informatica worden knelpunten in de personeelsvoorziening verwacht, maar hier speelt dat er weinig opleidingen zijn die voorzien in de vraag naar bevoegde leraren voor het vak informatica. Voor vakken als Nederlands, Engels, economie en geschiedenis lijken er weinig problemen in de personeelsvoorziening te ontstaan.

Factoren die samenhangen met de spanning op de arbeidsmarkt voor leraren, zijn de leerling-leraar ratio en de mate waarin onbevoegde leraren worden ingezet. Scholen kunnen bijvoorbeeld kiezen voor onbevoegden bij een te gering aanbod van bevoegde leraren of als de aanstellingsomvang voor bepaalde vakken klein is. 
TABEL 3.5 Toekomstige arbeidsmarktperspectieven naar opleiding (ITA) voor schoolverlaters, 20152020

\begin{tabular}{|l|r|r|}
\hline & ITA & Typering Arbeidsmarktperspectieven \\
\hline mbo 2/3 groen & 1,01 & redelijk \\
\hline mbo 2/3 economie & 1,11 & matig \\
\hline mbo 2/3 techniek & 1,03 & redelijk \\
\hline mbo 2/3 zorg en welzijn & 1,23 & slecht \\
\hline mbo 4 groen & 1,00 & goed \\
\hline mbo 4 economie & 1,10 & matig \\
\hline mbo 4 techniek & 1,02 & redelijk \\
\hline mbo 4 zorg en welzijn & 1,21 & slecht \\
\hline hbo onderwijs & 0,95 & goed \\
\hline hbo taal en cultuur & 1,12 & matig \\
\hline hbo economie & 1,13 & matig \\
\hline hbo techniek & 0,92 & goed \\
\hline hbo landbouw en natuur & 0,98 & goed \\
\hline hbo gezondheidszorg & 1,12 & matig \\
\hline hbo gedrag en maatschappij & 1,12 & matig \\
\hline wo onderwijs & 1,07 & matig \\
\hline wo taal en cultuur & 1,04 & redelijk \\
\hline wo economie en recht & 1,04 & redelijk \\
\hline wo techniek & 0,89 & goed \\
\hline wo landbouw en natuur & 0,98 & goed \\
\hline wo medisch & 1,09 & matig \\
\hline wo gedrag en maatschappij & 1,03 & redelijk \\
\hline Totaal (incl. overig) & 1,01 & redelijk \\
\hline
\end{tabular}

Bron: ROA (AIS)

Voor afgestudeerden van universitaire opleidingen variëren de perspectieven op de arbeidsmarkt tot 2020 van matig voor de richtingen onderwijs en medisch tot goed voor de richtingen techniek en landbouw en natuur (voor de overige opleidingscategorieën zijn de perspectieven redelijk). De goede perspectieven van de twee laatstgenoemde opleidingscategorieën worden vooral gedreven door een hoge vervangingsvraag. Voor het opleidingstype wo informatica zorgt de banengroei (positieve uitbreidingsvraag) voor beroepen in de ICT zelfs voor zeer goede perspectieven voor afgestudeerden. Net als voor het hbo geldt dat de arbeidsmarktperspectieven voor geen enkele opleidingscategorie gemiddeld genomen slecht zijn. Voor wo onderwijs en wo medisch wordt relatief weinig werkgelegenheidsgroei verwacht, waardoor de perspectieven van afgestudeerden uit deze opleidingen matig zijn. Door de lage vervangingsvraag voor het opleidingstype wo gezondheidszorg zijn de arbeidsmarktkansen van afgestudeerden van deze opleidingen zelfs slecht (in tegenstelling tot wo (dier)geneeskunde en tandheelkunde met redelijke perspectieven). Wo gediplomeerden van economie en recht hebben redelijke perspectieven. Opvallend zijn de goede vooruitzichten voor gediplomeerden van opleidingstype wo economie, gedreven door een bovengemiddelde 
werkgelegenheidsgroei en lage instroom van gediplomeerden vanuit deze opleidingen in de komende jaren.

\subsection{Toekomstige knelpunten in de personeelsvoorziening naar beroep}

In de voorgaande paragraaf zijn de arbeidsmarktperspectieven van gediplomeerden besproken (ITA's), waarbij de afgeronde opleiding het uitgangspunt vormt. De ontwikkelingen die hieraan ten grondslag liggen, te weten de omvang van het aanbod van gediplomeerden op de arbeidsmarkt en de verwachte uitbreidings- en vervangingsvraag, hebben ook hun weerslag op de arbeidsmarkt voor de verschillende beroepsgroepen. Voor een bepaald aantal beroepen worden specifieke kennis en vaardigheden vereist die vooral aanwezig zijn bij personen met een bepaalde opleidingsachtergrond. Anders gezegd, bij het vervullen van baanopeningen voor een beroep is de werkgever afhankelijk van het aanbod van instromers met een opleidingsachtergrond die past bij dat beroep. Het aanbod (een 'overschot' of een 'tekort') aan gediplomeerden bepaalt of werkgevers weinig of veel problemen zullen hebben om in de komende zes jaar voldoende geschikt personeel te vinden dat beschikt over de vereiste kwalificaties. Werkgevers met een zoektocht naar beroepsspecifieke expertise zullen de knelpunten moeilijker opgelost krijgen, omdat er weinig alternatieven zijn. Werkgevers die kunnen putten uit werkenden uit verschillende opleidingsachtergronden voor het vervullen van hun baanopeningen zullen waarschijnlijk gemakkelijker in hun personeelsbehoefte voorzien.

De Indicator Toekomstige Knelpunten in de Personeelsvoorziening naar Beroep (ITKB) geeft inzicht in de wijze waarop de aansluitingsproblematiek tussen onderwijs en arbeidsmarkt van invloed zijn op de wervingsproblematiek in de verschillende beroepsgroepen. De ITKB geeft de kans aan dat de vraag vanuit een bepaalde beroepsgroep in de gewenste samenstelling vervuld kan worden, rekening houdend met de vraag-aanbodverhoudingen voor de verschillende opleidingstypen. ${ }^{98}$ Deze indicator heeft een waarde tussen o en 1. Naarmate de indicator lager is, zijn de knelpunten groter voor de werving vanuit de opleidingscategorieën die voor de betreffende beroepsgroepen relevant zijn. Bij een score die dichter bij 1 ligt zullen werkgevers de komende jaren minder moeite hebben om de gewenste personeelssamenstelling te realiseren.

Inzicht in de knelpunten naar beroep is voor verschillende gebruikers en gebruiksdoelen van belang. Allereerst formuleren werkgevers de behoefte aan nieuw personeel vaak primair in termen van functiecategorieën of beroepen. Zij zijn immers op zoek naar iemand die bepaalde taken - gebundeld in een bepaalde functiecategorie - binnen de organisatie kan vervullen. Voor werkgevers kan inzicht in de knelpunten naar beroepsgroep dus van belang zijn voor hun wervings- en personeelsbeleid. Daarnaast kunnen (langdurige) werklozen of werkenden die op zoek zijn naar een andere werkkring

98 Zoals eerder toegelicht (zie 'Doel en opzet') is bij de berekening van de ITKB's dit jaar rekening gehouden met het verwachte aanbod van scholieren in kleine banen. 
gebruik maken van de informatie over de knelpunten in de personeelsvoorziening naar beroep in hun oriëntatie naar een nieuwe of andere werkkring. Nauw samenhangend met het tweede gebruiksdoel zijn de bij- en omscholingsprogramma's, omdat deze doorgaans gericht zijn op een bepaald beroep. Inzicht in de knelpunten naar beroep kan als leidraad dienen bij het vormgeven en inrichten van dergelijke scholingsprogramma's.

Tabel 3.6 geeft de verwachte knelpunten in de personeelsvoorziening voor werkgevers naar beroepsklasse weer voor de periode 2015-2020. Voor elke beroepsklasse wordt de ITKB en de bijbehorende typering weergeven. De laatste twee kolommen van de tabel laten het percentage van de vraag zien waarvoor werkgevers (vrijwel) geen of (zeer) grote knelpunten kunnen verwachten. De percentages zijn gebaseerd op de typeringen van de knelpunten van de beroepsgroepen die samen een beroepsklasse vormen (zie bijlage B). De tabel laat zien dat werkgevers tot 2020 (vrijwel) geen knelpunten zullen hebben om de gewenste personeelssamenstelling te realiseren voor de helft van het gevraagde personeel. Voor $26 \%$ van de vraag naar werkenden zullen werkgevers wel met (zeer) grote knelpunten geconfronteerd worden.

TABEL 3.6 Toekomstige knelpunten in de personeelsvoorziening naar Beroep (ITKB) voor werkgevers, en percentage van vraag met (vrijwel) geen en (zeer) grote knelpunten, 2015-2020

\begin{tabular}{|l|r|r|r|r|}
\hline & ITKB & ITKB-typering & $\begin{array}{r}\text { (Vrijwel) geen } \\
\text { knelpunten } \%\end{array}$ & $\begin{array}{r}\text { (Zeer) grote knelpunten } \\
\%\end{array}$ \\
\hline Pedagogische beroepen & 0,878 & Groot & 23 & 71 \\
\hline Creatieve en taalkundige beroepen & 0,913 & Vrijwel geen & 28 & 0 \\
\hline Commerciële beroepen & 0,934 & Geen & 73 & 0 \\
\hline Bedrijfseconomische en administratieve beroepen & 0,904 & Enige & 35 & 17 \\
\hline Managers & 0,802 & Groot & 13 & 65 \\
\hline Openbaar bestuur, veiligheid en juridische beroepen & 0,908 & Enige & 49 & 22 \\
\hline Technische beroepen & 0,871 & Groot & 26 & 55 \\
\hline ICT-beroepen & 0,853 & Groot & 0 & 80 \\
\hline Agrarische beroepen & 0,927 & Vrijwel geen & 85 & 0 \\
\hline Zorg- en welzijnsberoepen & 0,954 & Geen & 80 & 0 \\
\hline Dienstverlenende beroepen & 0,929 & Vrijwel geen & 84 & 4 \\
\hline Transport- en logistiekberoepen & 0,933 & Geen & 86 & 4 \\
\hline Totaal (incl. overig) & - & - & 50 & 26 \\
\hline Bron:
\end{tabular}

Bron: $\operatorname{ROA}(\mathrm{AIS})$

Uit tabel 3.6 kan verder worden geconcludeerd dat werkgevers de komende zes jaren rekening moeten houden met grote knelpunten voor de pedagogische beroepen. Voor $71 \%$ van de vraag naar werkenden in de pedagogische beroepsklasse worden (zeer) grote knelpunten voorzien. Voor bijna alle onderliggende beroepsgroepen zullen er grote knelpunten optreden met uitzondering van sportinstructeurs (geen knelpunten) en leidsters kinderopvang en onderwijsassistenten (geen knelpunten). Nog grotere knelpunten zullen optreden bij het vinden van personeel voor ICT-beroepen. Voor de beroepsgroep gebruikersondersteuning ICT en radio-televisietechnici speelt bijvoor- 
beeld de bovengemiddelde verwachte vervangingsvraag een belangrijke rol (zie verder tekstbox 3.3). Ook voor de technische beroepen en managers kan de komende jaren grote schaarste aan personeel worden verwacht. Grote tot zeer grote knelpunten worden voorzien voor meer dan de helft van de vraag naar mensen in technische beroepen.

TEKSTBOX 3.3 Arbeidsmarkt voor IT'ers ${ }^{99}$

In de IT zijn de perspectieven goed voor hbo-gediplomeerden en zelfs zeer goed voor wo-gediplomeerden (Zie ook: UWV, Arbeidsmarkt techniek en ICT trekt verder aan, 11 september 2015). Tevens worden er knelpunten verwacht voor software- en applicatieontwikkelaars, gebruikersondersteuning ICT en managers ICT. In de ICT-sector geldt nog meer dan in andere sectoren: Nieuwe kennis en vaardigheden volgen elkaar snel op. Denk hierbij aan technologische ontwikkelingen zoals cloud computing en big data, maar ook aan manieren van werken zoals het 'agile' ontwikkelen van software. Binnen de sector zijn een tweetal trends duidelijk zichtbaar. Een eerste trend is de groeiende vraag naar de combinatie van IT- en businesskennis. Dit zijn beroepen waarbij een technisch profiel gecombineerd moet worden met een commerciële inslag. Een andere trend relateert aan data. Datawetenschappers die in het big data veld waarde kunnen toevoegen aan organisaties. In de ICT gaan de markten en de innovaties verschrikkelijk snel. Dit is de kracht van ICT, maar de uitdaging op opleidingsgebied.

In tegenstelling tot bovengenoemde beroepsklassen worden voor de creatieve en taalkundige beroepen nauwelijks knelpunten verwacht in de personeelsvoorziening. Voor bijvoorbeeld bibliothecarissen en conservatoren speelt hier de negatieve uitbreidingsvraag een belangrijke rol. In de aankomende jaren zullen werkgevers vrijwel geen moeite hebben om personeel te vinden als het gaat om bibliothecarissen en conservatoren, journalisten en fotografen en interieurontwerpers.

In de agrarische beroepen zal de vraag naar werkenden in $85 \%$ van de gevallen (vrijwel) geen knelpunten opleveren. In deze beroepen is vaak sprake van krimp en in hoofdstuk 2 kwam al naar voren dat het aandeel gediplomeerden dat instroomt op de arbeidsmarkt ongeveer even groot is als het aantal baanopeningen in de aankomende prognosejaren (groene opleidingen). Werkgevers zullen vrijwel geen moeite hebben met de gewenste personeelssamenstelling als het gaat om hoveniers, tuinders, kwekers en veetelers.

Voor slechts $4 \%$ van de vraag naar arbeidskrachten met een dienstverlenend beroepssoort worden (zeer) grote problemen verwacht aangaande de personeelswerving. In de toekomst zullen werkgevers van kappers, schoonheidsspecialisten, conciërges en teamleiders van schoonmaak geen moeite hebben met de gewenste personeelssamenstelling. Binnen deze beroepsklasse zijn verleners van overige persoonlijke diensten de enige werkenden waarvoor naar verwachting wel grote knelpunten zullen ontstaan in de personeelssamenstelling.

99 Deze tekstbox is tot stand gekomen met de medewerking van Ivo Poulissen, beleidsadviseur Nederland ICT. 
Voor de bedrijfseconomische en administratieve beroepen worden enige knelpunten verwacht voor werkgevers. In vier van de dertien onderliggende beroepsgroepen zullen op de middellange termijn (vrijwel) geen problemen ontstaan bij het vinden van voldoende gekwalificeerde vakkrachten. Dit betreft onder andere boekhouders en secretaresses, waarvoor een sterke werkgelegenheidskrimp wordt verwacht. Er wordt echter wel schaarste verwacht bij financieel specialisten en economen, accountants en zakelijke dienstverleners. Ook bij de beroepsgroepen die samen het openbaar bestuur, veiligheid en de juridische beroepen vormen, worden enige knelpunten verwacht voor werkgevers. In hoofdstuk 2 kwam al aan bod dat er in de toekomst meer vraag zou komen naar beveiligingspersoneel. Dit is ook het enige beroep in deze beroepsklasse waarvoor werkgevers grote moeilijkheden zullen ondervinden bij het vinden van geschikt personeel.

Voor de zorg- en welzijnsberoepen is de ITKB hoog en worden er dus vrijwel geen problemen voorzien bij het opvullen van vacatures die zullen ontstaan binnen deze beroepsklasse. In hoofdstuk 2 bleek al dat er op de arbeidsmarkt weinig vraag is naar werkenden met een studie-achtergrond in zorg en welzijn, terwijl het arbeidsmarktaanbod van recent gediplomeerden relatief groot is (zie ook tekstbox 3.1). De verhouding tussen vraag en aanbod is gunstig voor werkgevers, die naar verwachting geen knelpunten zullen ondervinden in de toekomst. Ook in de commerciële beroepen zullen zich de komende jaren (vrijwel) geen knelpunten voordoen. Bij vier van de zes beroepen geeft de indicator aan dat werkgevers (vrijwel) geen moeite zullen hebben om de gewenste personeelssamenstelling te realiseren.

Tot slot zal het invullen van vacatures voor transport- en logistiekberoepen, naar verwachting, in $86 \%$ van de gevallen geen grote problemen met zich meebrengen. Het betreft hierbij onder andere vrachtwagenchauffeurs en vuilnisophalers en dagbladenbezorgers. De vervangingsvraag, die bepalend is voor de baanopeningen, is weliswaar bovengemiddeld (zie tabel 2.3) - voor vrachtwagenchauffeurs bijvoorbeeld is de vervangingsvraag gelijk aan $3,7 \%$ per jaar (2,9\% gemiddeld over alle beroepen) $)^{100}$ - maar daar staat een aanbod tegenover dat kennelijk voldoende groot is om de baanopeningen te vullen. De verwachting dat er bij het werven van vrachtwagenchauffeurs geen knelpunten worden voorzien sluit aan bij de in paragraaf 2.2 genoemde bevinding van het CBS dat het aantal Nederlandse vrachtauto's in recente jaren gestaag afneemt. ${ }^{101}$ Voor slechts $4 \%$ van de totale vraag naar werkenden in deze richting worden namelijk problemen verwacht aangaande de personeelswerving. Het betreft hier de vacatures die zullen ontstaan voor dekofficieren en piloten. Het vinden van voldoende geschikt personeel zal hier om een grote inspanning vragen van de werkgevers. Merk op dat er voor chauffeurs auto's, taxi's en bestelwagens (waar de vervangingsvraag hoog is) en transportplanners en logistiek medewerkers (een beroepsgroep dat ondergebracht

100 Zie ook: http://www.logistiek.nl/distributie/nieuws/2011/5/tekort-chauffeurs-dreigt-vanaf-2015-10151722

101 Bron: CBS (2015), Meer trekkers dan vrachtauto's, http://www.cbs.nl/nl-NL/menu/themas/verkeer-vervoer/ publicaties/artikelen/archief/2015/meer-trekkers-dan-vrachtautos.htm 
is bij bedrijfseconomische en administratieve beroepen) enige knelpunten verwacht worden. ${ }^{102}$

\subsection{Conclusie}

Vraag en aanbod op de arbeidsmarkt zijn bepalend voor de arbeidsmarktpositie van schoolverlaters. Wanneer de vraag naar personeel met een bepaalde opleidingsachtergrond het aanbod overstijgt, ontstaat er krapte op de arbeidsmarkt en zullen schoolverlaters met deze opleidingsachtergrond weinig moeite hebben bij het vinden van een passende baan. Blijft de vraag achter bij het aanbod, dan leidt dit tot een ruime arbeidsmarkt en daarmee tot slechte arbeidsmarktvooruitzichten voor nieuwkomers op de arbeidsmarkt. Slechte arbeidsmarktperspectieven zullen zich uiten in meer werkloosheid, lagere lonen en/of het moeten accepteren van werk onder het eigen niveau of buiten de eigen richting.

In dit hoofdstuk zijn wij eerst stil blijven staan bij de huidige aansluiting tussen vraag een aanbod voor recent gediplomeerden. Daaruit bleek dat de arbeidsmarkt voor recent gediplomeerden in 2014 minder gunstig was dan in 2010. De werkloosheid onder recent gediplomeerden lag in 2014 met 8,8\% hoger dan in 2010 (4,7\%). Ook op basis van andere indicatoren kan worden geconcludeerd dat de arbeidsmarktpositie van pas afgestudeerden in 2014 bepaald niet rooskleurig was. De beloning in 2014 lag als gevolg van de economische crisis aanzienlijk lager dan in 2010, er was vaker sprake van verticale en/of horizontale mismatches en het aandeel gediplomeerden met een kleine baan is toegenomen. Het is echter belangrijk om op te merken dat de jeugdwerkloosheid de laatste twee jaar langzaam weer afneemt (zie hoofdstuk 1).

Het uitblijven van (sterke) economische groei na de crisis van 2008 heeft ervoor gezorgd dat het aantal jongeren dat zich aanbiedt op de arbeidsmarkt in 2014 ruim hoger ligt dan het aantal vacatures voor starters. Onder middelbaar gediplomeerden was de aansluiting tussen onderwijs en arbeidsmarkt in 2014 relatief het beste voor gediplomeerden van de opleidingscategorie zorg en welzijn; de werkloosheid was relatief laag en de kwalitatieve aansluiting doorgaans beter dan onder gediplomeerden van andere studierichtingen binnen het middelbaar beroepsonderwijs. De groeiperspectieven tot 2020 voor de richtingen zorg en welzijn zijn echter karig; er wordt dan ook gerekend op een verslechtering in de aansluiting onderwijs-arbeidsmarkt voor gediplomeerden uit de zorg- en welzijnopleidingen in de komende zes jaar. In het mbo ervaren recent gediplomeerden van economische opleidingen vergeleken met andere opleidingen de slechtste aansluiting met de arbeidsmarkt. In het hbo zijn het de gediplomeerden van techniek die de beste start hebben op de arbeidsmarkt. Universitaire gediplomeerden van opleidingen in de opleidingscategorieën medisch, techniek en landbouw en natuur scoren goed op vrijwel alle aansluitingsindicatoren (met uitzondering van de loonindicator voor gediplomeerden van landbouw en natuur).

102 Dit geldt eveneens voor managers logistiek. 
In dit hoofdstuk zijn de verwachte vraag-en aanbodstromen, zoals beschreven in hoofdstuk 2, met elkaar geconfronteerd, wat resulteert in de Indicator Toekomstig Arbeidsmarktperspectief (ITA). Met deze indicator wordt per opleidingscategorie voor schoolverlaters een verwachting gegeven van hun arbeidsmarktperspectieven op de middellange termijn. Daarnaast is in dit hoofdstuk aandacht besteed aan de vooruitzichten vanuit werkgeversperspectief, door een indicatie te geven van de toekomstige knelpunten in de personeelsvoorziening naar beroep (ITKB).

De arbeidsmarktperspectieven voor jongeren die in de periode 2015-2020 de arbeidsmarkt zullen betreden zijn gemiddeld genomen over alle opleidingscategorieën redelijk. Over het algemeen kan men stellen dat de perspectieven slecht tot redelijk zijn voor mbo-gediplomeerden en beter worden naarmate het opleidingsniveau hoger ligt. De arbeidsmarktperspectieven van gediplomeerden in het mbo verschillen sterk naar niveau en richting. Op mbo $2 / 3$ niveau zijn de perspectieven redelijk in de richting groen en techniek. Op mbo 4 niveau zijn de perspectieven goed voor groene opleidingen ( $m b o 4$ voedsel, natuur en milieu) en redelijk voor techniek (met goede perspectieven voor mbo 4 werktuigbouwkunde en metaalbewerking, technische installatie en bouw en infra). Techniek en groen hebben over het algemeen ook goede perspectieven op hbo- en wo-niveau, met zelfs zeer goede perspectieven voor hbo werktuigbouwkunde, hbo chemie en wo informatica). Ook voor hbo onderwijs zijn de perspectieven goed.

De arbeidsmarktsituatie voor schoolverlaters met een diploma in een zorgopleiding ${ }^{103}$ zal de komende jaren minder zijn dan in de afgelopen jaren, ongeacht het opleidingsniveau. Stijgende eigen bijdragen, eigen risico's en druk op de budgetten vanuit gemeenten, zorgverzekeraars en bezuinigingen door de overheid zorgen ervoor dat de werkgelegenheidsgroei in de zorg stagneert. De beste perspectieven (redelijk) zijn er voor wo (dier)geneeskunde en tandheelkunde. Merk overigens op dat in de jaren vanaf 2017 er weer sprake zal zijn van een voorzichtige banengroei hetgeen tot een herstel van de goede perspectieven zou kunnen leiden tegen het einde van de prognoseperiode.

Toekomstige ontwikkelingen in vraag en aanbod zijn ook bepalend voor de personeelswerving door werkgevers. De verwachte knelpunten in de personeelsvoorziening voor werkgevers zijn het grootst in de ICT- en technische beroepen, pedagogische beroepen en voor managersfuncties. Werkgevers in transport- en logistiekberoepen zullen naar verwachting (vrijwel) geen moeite hebben bij het vullen van openstaande vacatures, al zijn er wel knelpunten voor beroepen als dekofficieren en piloten, en enige knelpunten voor chauffeurs auto's, taxi's en bestelwagens en transportplanners en logistiek medewerkers. Ook werkgevers van zorg- en welzijnsberoepen zullen naar verwachting geen problemen hebben met het vinden van geschikt personeel. Tot slot zal het invullen van vacatures voor commerciële beroepen, naar verwachting, geen problemen met zich meebrengen omdat de instroom van jongeren voor die beroepen hoog is.

103 Onder zorgopleidingen verstaan we mbo $2 / 3$ en mbo 4 zorg en welzijn, hbo gezondheidszorg en wo medisch. 



\section{4 \\ VERSCHUIVINGEN IN DE BEROEPENSTRUCTUUR 1996-2014}

\subsection{Inleiding}

De structuur van de Nederlandse arbeidsmarkt verandert sterk. Dit betreft zowel verschuivingen in de beroepenstructuur als de opleidings- en leeftijdsstructuur van de werkende beroepsbevolking. Beroepen komen en gaan als gevolg van veranderingen in de vraag naar arbeid, het gemiddelde opleidingsniveau onder de werkzame beroepsbevolking gaat omhoog als gevolg van skills upgrading, en ook de gemiddelde leeftijd van de werkzame beroepsbevolking stijgt onder invloed van de vergrijzing. Deze ontwikkelingen hebben gevolgen voor de kwantitatieve en kwalitatieve aspecten van de vraag en het aanbod binnen het prognosemodel.

Voor deze verschuivingen is veel aandacht. In landen van de Organisatie voor Economische Samenwerking en Ontwikkeling (OESO) is het percentage hoogopgeleiden in de bevolking gegroeid van $22 \%$ in 2000 naar $33 \%$ in 2012 . Onder $25-34$ jarigen was deze toename nog sterker: het percentage hoogopgeleiden is in die leeftijdsgroep gestegen van $26 \%$ in 2000 naar $40 \%$ in $2012 .{ }^{104}$ Het aanbod van hoogopgeleiden neemt toe, maar de vraag naar hoogopgeleiden neemt nog sterker toe: werkgevers stellen steeds hogere kwalificatie-eisen aan werknemers die werkzaam zijn in hun organisaties. ${ }^{105}$ De stijgende kwalificatie-eisen van de werkzame beroepsbevolking wordt doorgaans toegeschreven aan globalisering, de technologische ontwikkelingen en het toenemend gebruik van computers, ${ }^{106}$ maar ook aan veranderingen in organisatiestructuren. ${ }^{107}$ Naast een stijgend gemiddeld opleidingsniveau, wordt voor verschillende landen ook gesproken van polarisering. Dit wil zeggen dat er relatief veel banen op middelbaar niveau verdwijnen. Technologische veranderingen en de opkomst van computers zouden namelijk substituut zijn voor productie- en kantoorwerkzaamheden op middelbaar niveau, maar complementair op non-routinematig werk op laag en hoog niveau. ${ }^{108}$ Verschillende

104 OECD (2014), Education at a Glance 2014: OECD Indicators, Paris: OECD Publishing.

105 Jacobs, B. (2004), The lost race between schooling and technology, De Economist, 152(1), 47-78.

106 Katz, L. \& Autor, D. (1999), Changes in the wage structure and earnings inequality, In O. Ashenfelter \& D. Card (red.), Handbook of Labor Economics, vol. 3 (pp. 1463-1555), Amsterdam: Elsevier.

107 Caroli, E., \& Van Reenen, J. (2001), Skill-biased organizational change? Evidence from a panel of British and French establishments, Quarterly Journal of Economics, 1449-1492.

108 Zie ook het recent verschenen UWV-rapport rond administratieve beroepen. 
studies ondersteunen deze hypothese voor de Verenigde Staten van Amerika, ${ }^{109}$ het Verenigd Koningrijk, ${ }^{100}$ Duitsland ${ }^{111}$ en andere Europese en OESO landen. ${ }^{11,113}$

Daarnaast is er nog sprake van een stijgende gemiddelde leeftijd en het percentage werkende 55-plussers als gevolg van de vergrijzing en ontgroening van de samenleving. Door beleidsmaatregelen op het gebied van pensioenen worden werkenden aangemoedigd om langer actief te blijven op de arbeidsmarkt. ${ }^{114}$ Het langer doorwerken heeft consequenties voor de vervangingsvraag: als werkgevers de uitstroom van personeel zien verminderen doordat men langer doorwerkt zal dit resulteren in een kwantitatief lagere vervangingsvraag. Op korte termijn zou dit kunnen betekenen dat de perspectieven voor jongeren die nieuw binnenkomen op de arbeidsmarkt slechter worden. Op de middellange termijn kan echter verwacht worden dat de uitstroom van het grote cohort 50-plussers, verhoging van de gemiddelde uittredeleeftijd ten spijt, tekorten zullen veroorzaken. ${ }^{15}$ Naast de kwantitatieve aspecten spelen ook de kwalitatieve aspecten van de vervangingsvraag een belangrijke rol. Zo is het de vraag of door de snelle technologische en organisatorische ontwikkelingen van de afgelopen decennia, het vertrek van een werknemer resulteert in een vraag naar een nieuwe werknemer met dezelfde of een hogere opleidingsachtergrond.

Tegen deze achtergrond gaat dit hoofdstuk in op de verschuivingen die zich hebben voorgedaan in de beroepen-, opleidings- en leeftijdsstructuur op de Nederlandse arbeidsmarkt in de laatste 20 jaar. Hierbij wordt gekeken naar de periode 1996-2014 aan de hand van de nieuwe Beroepenindeling ROA-CBS (BRC 2014). ${ }^{116}$ Bovendien geeft dit hoofdstuk inzicht in de veranderde leeftijdsstructuur van de werkenden binnen beroepen. Dit is relevant om beter zicht te krijgen op de vervangingsvraag naar beroep die voor een belangrijk deel bepaald wordt door het uittredingsgedrag van werkenden.

De analyses zijn gebaseerd op data van de Enquête Beroepsbevolking (EBB) van het Centraal Bureau voor de Statistiek (CBS) aangevuld met cijfers over de loontwikkeling

109 Autor, D., Katz, L. \& Kearney, M (2006), The polarization of the U.S. labor market, American Economic Review, 96, 189-94; Autor, D., Katz, L. \& Kearney, M. (2008), Trends in U.S. wage inequality: revising the revisionists, Review of Economics and Statistics, 90, 300-23.

110 Goos, M., \& Manning, A. (2007), Lousy and lovely jobs: the rising polarization of work in Britain, The Review of Economics and Statistics, 89, 118-133.

111 Spitz-Oener, A. (2006), Technical change, job tasks, and rising educational demands: looking outside the wage structure, Journal of Labor Economics, 24, 235-270.

112 Goos, M., Manning, A., \& Salomons, A. (2009), Job polarization in Europe, The American Economic Review, 58-63; Goos, M., Manning, A., \& Salomons, A. (2014), Explaining job polarization: routine-biased technological change and offshoring, American Economic Review, 104, 2509-2526.

113 Over polarisatie in Nederland is recentelijk gepubliceerd door: Van den Berge en ter Weel (2015), Middensegment onder druk. Nieuwe kansen door technologie, CPB Policy Brief 2015/13.

114 Grip, A. de, D. Fouarge \& R. Montizaan (2013), How sensitive are individual retirement expectations to raising the retirement age? De Economist, 161(3): 225-251.

115 Zie ook ROA (2013), De arbeidsmarkt naar opleiding en beroep tot 2018, Maastricht: ROA-R-2013/11.

116 Voor de gebruikte methode, zie I. Bijlsma, S. Dijksman, D. Fouarge, A. Künn-Nelen (2015), Winnaars en verliezers op de arbeidsmarkt 1996-2012, Tijdschrift voor Arbeidsvraagstukken, 31 (2),106-123, die gebruik maken van de oude beroepenclassificatie van het ROA. Hier gaan wij in op verschuivingen voor de periode 1996-2014 aan de hand van de nieuwe Beroepenindeling ROA-CBS; zie: ROA (2015) Beroepenindeling ROA-CBS 2014 (BRC 2014), ROA-TR-2015/5. 
in beroepen uit het Arbeidsaanbodpanel en met cijfers uit het onder de leiding van de OESO uitgevoerde Programme for the International Assessment of Adult Competencies (PIAAC). De EBB-data dekken de jaren 1996-2014. De PIAAC-data zijn uit 2012. In de EBB zijn de beroepen gecodeerd volgens de nieuwe BRC 2014 beroepenindeling. Hierbij wordt een onderscheid gemaakt tussen 114 beroepsgroepen die geclusterd zijn in 13 beroepsklassen. Voor de analysen zijn beroepsgroepen met minder dan 5.000 waarnemingen buiten beschouwing gelaten.

In paragraaf 4.2 bespreken we de veranderingen in de beroepenstructuur in de periode 1996-2014. ${ }^{17}$ We rapporteren de top 10 van de sterkst groeiende en de sterkst krimpende beroepen. Door aanvullende data van PIAAC te gebruiken gaan we bovendien in op de vraag of beroepen waarin het computergebruik en het niveau van probleemoplossend vermogen hoger zijn met name groei- of krimpberoepen zijn. In paragraaf 4.3 richten we ons op de opleidingsstructuur. Zo analyseren we in welke mate het gemiddelde opleidingsniveau van werkend Nederland in die periode is veranderd en daarmee of er sprake is van een kennisintensivering van de economie. Door middel van een shift-share analyse wordt nagegaan of de verandering in het gemiddelde opleidingsniveau het gevolg is van een andere beroepenstructuur of dat er voor beroepen hogere opleidingseisen gelden. Vervolgens laten we voor 12 beroepsklassen (beroepsklasse overig wordt hier niet weergegeven) eenzelfde analyse zien om te onderzoeken of er verschillen zijn in de kennisintensivering in bepaalde segmenten van de arbeidsmarkt. In paragraaf 4.4 analyseren we de leeftijdsstructuur van beroepen en de mate waarin deze veranderd is in de periode 1996-2014. Vervolgens wordt het percentage 55-plussers per beroep gerelateerd aan de werkgelegenheidsontwikkeling van die beroepen in de periode 1996-2014. Zo kan een beeld worden geschetst van de mate waarin groei en krimp in beroepen gerelateerd is aan de leeftijdsstructuur van die beroepen. Met het oog op de kwalitatieve gevolgen van veroudering van de beroepsbevolking voor de vervangingsvraag, wordt ook bekeken in hoeverre het opleidingsniveau van jongeren en ouderen binnen beroepen vergelijkbaar is. Paragraaf 4.5 bevat de conclusies.

\subsection{Beroepenstructuur 1996-2014}

Per beroep wordt de ontwikkeling in werkgelegenheid berekend op basis van de EBB voor de jaren 1996-2014. ${ }^{118}$ Allereerst wordt de relatieve groei (in procenten) en krimp van de werkgelegenheid binnen beroepen besproken. ${ }^{119}$ Voor de relatieve werkgelegenheidsontwikkeling wordt uitgegaan van de trendmatige ontwikkeling in het aantal

117 Het gaat hier dus om arbeidsmarktontwikkelingen in de jaren sinds 1996, en niet om prognoses van vraagaanbodverhoudingen. Deze zijn aan bod gekomen in hoofdstuk 3.

118 Zoals eerder aangegeven (Doel en opzet van arbeidsmarktprognoses) is met het herontwerp van de EBB een trendbreuk ontstaan vanaf 2013. Deze trendbreuk wordt in de berekening van de trendmatige ontwikkeling in beroepen gemodelleerd.

119 Dit in tegenstelling tot de absolute verandering in het aantal werkenden, die laat zien waar de grote werkgelegenheidsverschuivingen zich hebben voorgedaan sinds 1996. 
werkenden waardoor de gepresenteerde cijfers betrekking hebben op gemiddelde veranderingen per jaar.

Vervolgens delen wij de beroepsgroepen in aan de hand van het modale, ofwel meest voorkomende, opleidingsniveau (MON) van werkenden in die beroepen (uitgaand van het hoogst behaald opleidingsniveau) en bespreken wij de ontwikkeling in de verdeling van de werkgelegenheid over de jaren 1996-2014. Ook analyseren wij de verandering in het gemiddeld opleidingsniveau (GON) van de beroepsbevolking. Het GON wordt berekend aan de hand van het aantal opleidingsjaren na het basisonderwijs: 3 jaar voor vmbo, 6 jaar voor havo, vwo en mbo, 9 jaar voor hbo en 12 jaar voor wo (De Grip \& Dijksman, 2004).

TABEL 4.1 Grootste occupational winners gemeten in jaarlijkse relatieve aantallen (gemiddeld per jaar), gemiddeld (GON) en modaal opleidingsniveau (MON), 1996-2014

\begin{tabular}{|l|r|r|r|r|r|r|}
\hline Beroepsnaam & $\begin{array}{r}\text { Aantal } \\
2014\end{array}$ & $\begin{array}{r}\text { Trend in } \\
\text { procenten } \\
\text { per jaar }\end{array}$ & & GON 1996 & GON 2014 & MON \\
Sociaal werkers, groeps- en woonbegeleiders & 213.000 & 12,16 & 6,84 & 7,14 & mbo \\
\hline Managers zorginstellingen & 30.000 & 11,60 & 9,39 & 9,12 & hbo & mbo \\
\hline Zakelijke dienstverleners & 94.500 & 9,51 & 7,21 & 8,12 & mbo & hbo \\
\hline Bedrijfskundigen en organisatieadviseurs & 99.500 & 8,70 & 9,34 & 9,71 & hbo & hbo \\
\hline Financieel specialisten en economen & 64.000 & 8,35 & 9,86 & 9,15 & hbo & hbo \\
\hline Leidsters kinderopvang en onderwijsassistenten & 129.500 & 8,04 & 5,55 & 6,08 & mbo & mbo \\
\hline Sportinstructeurs & 37.500 & 7,89 & 6,32 & 6,01 & mbo & mbo \\
\hline Procesoperators & 29.000 & 7,70 & 5,37 & 5,63 & mbo & mbo \\
\hline Grafisch vormgevers en productontwerpers & 51.000 & 7,67 & 8,12 & 7,79 & mbo & mbo \\
\hline Docenten beroepsgerichte vakken secundair onderwijs & 31.000 & 7,37 & 8,80 & 8,57 & hbo & hbo \\
\hline
\end{tabular}

Bron: ROA (bewerking EBB)

Tabel 4.1 geeft de top tien van de beroepsgroepen waar de werkgelegenheid in de jaren 1996-2014 gemiddeld per jaar relatief het sterkst is gegroeid (occupational winners). Op nummer 1 staan de sociaal werkers, groeps- en woonbegeleiders. Op nummer 2 staan de managers zorginstellingen. Beide beroepsgroepen hebben in de periode 1996-2014 een jaarlijkse procentuele stijging van meer dan 10\% gekend. Er zijn binnen de top 10 drie beroepsgroepen die vallen onder de pedagogische beroepen: Leidsters kinderopvang en onderwijsassistenten, sportinstructeurs, docenten beroepsgerichte vakken secundair onderwijs. Ook zijn er drie beroepsgroepen opgenomen die behoren tot de bedrijfseconomische en administratieve beroepen: zakelijke dienstverleners, bedrijfskundigen en organisatieadviseurs, financieel specialisten en economen. In deze top 10 zijn verder nog procesoperators en grafisch vormgevers en productontwerpers opgenomen. Vier van de beroepsgroepen in deze top 10 hadden in 1996 een modaal opleidingsniveau van hbo. In 2014 zijn daar twee beroepsgroepen bijgekomen. De zakelijke dienstverleners en de grafisch vormgevers en productontwerpers hebben in 2014 ook een modaal opleidingsniveau van hbo. De overige zes beroepsgroepen in deze top 10 
hebben een modaal opleidingsniveau van mbo. ${ }^{120}$ We merken op dat deze beroepen veelal in groeiende sectoren te vinden zijn, zoals de zakelijke dienstverlening.

In tabel 4.2 zijn de 10 beroepsgroepen opgenomen die in de periode 1996-2014 de grootste relatieve werkgelegenheidsdaling hebben laten zien, de zogenaamde occupational losers. Alle beroepsgroepen in de top 10 hebben een modaal opleidingsniveau gelijk aan (v)mbo. Meer dan de helft van deze beroepsgroepen zijn technische beroepen. Naast de nummers 1 en 2 in de lijst, medewerkers drukkerij en kunstnijverheid, en productiemachinebedieners, betreft het ook de assemblagemedewerkers, lassers en plaatwerkers, de projectleiders industrie en bouw, en de slagers. Drie andere beroepsgroepen vallen onder de bedrijfseconomische en administratieve beroepen: secretaresses, boekhoudkundig medewerkers en boekhouders. Ook de land- en bosbouwers behoren tot deze top 10 van occupational losers. Een aantal krimpberoepen zijn relatief oververtegenwoordigd in de industrie, wat een krimpende sector is, maar er is bij de krimpberoepen een grotere spreiding over krimp- en groeisectoren dan bij de groeiberoepen.

TABEL 4.2 Grootste occupational losers gemeten in jaarlijkse relatieve aantallen (gemiddeld per jaar), gemiddeld (GON) en modaal opleidingsniveau (MON), 1996-2014

\begin{tabular}{|c|c|c|c|c|c|c|}
\hline Beroepsnaam & $\begin{array}{r}\text { Aantal } \\
2014\end{array}$ & $\begin{array}{r}\text { Trend in } \\
\text { procenten } \\
\text { per jaar }\end{array}$ & GON 1996 & GON 2014 & $\begin{array}{l}\text { MON } \\
1996\end{array}$ & $\begin{array}{l}\text { MON } \\
2014\end{array}$ \\
\hline Medewerkers drukkerij en kunstnijverheid & 32.500 & $-3,82$ & 5,12 & 5,65 & mbo & mbo \\
\hline Productiemachinebedieners & 68.000 & $-3,16$ & 3,54 & 4,42 & vmbo & mbo \\
\hline Secretaresses & 60.500 & $-2,89$ & 5,76 & 6,19 & mbo & mbo \\
\hline Assemblagemedewerkers & 20.500 & $-2,86$ & 3,64 & 4,30 & vmbo & mbo \\
\hline Boekhoudkundig medewerkers & 129.500 & $-2,61$ & 5,19 & 6,36 & mbo & mbo \\
\hline Lassers en plaatwerkers & 31.500 & $-2,56$ & 3,66 & 4,30 & vmbo & mbo \\
\hline Productieleiders industrie en bouw & 57.500 & $-2,51$ & 5,63 & 5,82 & mbo & mbo \\
\hline Land- en bosbouwers & 29.500 & $-2,48$ & 4,36 & 5,51 & mbo & mbo \\
\hline Boekhouders & 93.000 & $-2,44$ & 6,45 & 7,35 & mbo & mbo \\
\hline Slagers & 20.500 & $-2,35$ & 3,53 & 4,31 & vmbo & mbo \\
\hline
\end{tabular}

Bron: ROA (bewerking EBB)

De werkgelegenheidsgroei hangt nauw samen met ontwikkelingen in de vraag naar arbeid. In een poging om inzicht te krijgen in de vraagfactoren die samenhangen met de werkgelegenheidsontwikkeling van beroepen, wordt ingegaan op zowel het IT-gebruik als de ontwikkeling van het loon in beroepen. In figuur 4.1 wordt de groei- en krimp in beroepsgroepen gerelateerd aan het computergebruik en probleemoplossend vermogen van werkenden in die beroepen. Wij gebruiken PIAAC-data om maatstaven

120 In tegenstelling tot Bijlsma et al. (2015) zijn er in deze top 10 minder hoog opgeleide beroepsgroepen opgenomen. Hier kunnen drie redenen aan ten grondslag liggen: de nieuwe classificatie, de toevoeging van de meest recente jaren, en de ILO-definitie die nu ook mensen meetelt die minder dan 12 uur per week werken. (I. Bijlsma, S. Dijksman, D. Fouarge, A. Künn-Nelen (2015). Winnaars en verliezers op de arbeidsmarkt 19962012, Tijdschrift voor Arbeidsvraagstukken, 31(2): 106-123). 
voor IT-gebruik en vaardigheden af te leiden. Daarbij onderscheiden we twee indicatoren:

- Het computergebruik op het werk dat aangeeft of een respondent al dan niet een computer gebruikt in zijn of haar dagelijks werk.

- Een objectieve test die het vermogen van personen meet om digitale technologie en communicatiemiddelen te gebruiken voor het verkrijgen en evalueren van informatie: het probleemoplossend vermogen in een digitale omgeving. ${ }^{121}$ De test meet twee dimensies: het probleemoplossend vermogen zelf (doel) en de ICT-vaardigheden (middel).

Het verdwijnen van banen wordt in de literatuur vaak toegewezen aan technologische ontwikkelingen. ${ }^{122}$ In deze context kijken wij naar de relatie tussen groei en krimp in beroepen en de mate van computergebruik en het probleemoplossend vermogen van werkenden in die beroepen door gebruik te maken van de beschikbare indicatoren van PIAAC. ${ }^{23}$ Het computergebruik op het werk is tegenwoordig wijdverspreid. De vraag is wat verwacht kan worden van de relatie tussen computergebruik in beroepen en de mate waarin beroepen groeien of krimpen. Als computers puur en alleen ingezet worden als arbeid-besparende technologie, dan zou men kunnen verwachten dat de werkgelegenheidsgroei negatief correleert met het computergebruik. Indien computers worden ingezet om het werk efficiënter of minder belastend te maken, dan hoeft dit negatief verwachte verband niet op te gaan. Omdat het routinematige werk aan het verdwijnen is, zou men kunnen verwachten dat de groei en krimp van beroepen in verband kan worden gebracht met het probleemoplossend vermogen.

Hoewel figuur 4.1 suggereert dat er sprake is van een positief verband tussen de relatieve werkgelegenheidsgroei in beroepen en de mate van computergebruik onder werkenden en het probleemoplossend vermogen in die beroepen, vinden we alleen een significante relatie voor de laatste indicator. De correlatie tussen groei van beroepen en het probleemoplossend vermogen in een digitale omgeving is 0,288 en is significant op 1 procent. Bij het testen van het probleemoplossend vermogen gaat het om taken zonder pasklare, routine oplossingen. Het gaat om het testen of personen in staat zijn om digitale middelen in te zetten om informatie op een efficiënte manier te vinden, te verwerken, te evalueren en te analyseren. ${ }^{124}$ De positieve en significante relatie sugge-

121 In PIAAC kregen personen zonder computervaardigheden de test niet voorgelegd. In Nederland betrof het ongeveer $10 \%$ van de respondenten. Voor hen is de score op een lage waarde (90) gezet. De maximale waarde op de test is 500 .

122 Autor, David H., Frank Levy, and Richard J. Murnane, (2003), The Skill-Content of Recent Technological Change: An Empirical Investigation, Quarterly Journal of Economics 118(4): 1279-1333.

123 Deze cijfers hebben betrekking op 2012. Helaas beschikken wij niet over een vergelijkbare maatstaf voor computergebruik in 1996 en 2014. Impliciet wordt dus verondersteld dat de beroepen die in 2014 hoog scoren op IT-gebruik en IT-vaardigheden dit ook deden in 1996.

124 Buisman, M., J. Allen, D. Fouarge, W. Houtkoop \& R. van der Velden (2013), PIAAC: Kernvaardigheden voor werk en leven. Resultaten van de Nederlandse survey 2012. 's Hertogenbosch: ECBO. 
reert dat groei-beroepen eerder complexe beroepen zijn. ${ }^{25}$ We vinden geen significante relatie tussen het computergebruik op zichzelf en de werkgelegenheidsontwikkeling. De figuur laat ook zien dat zowel het computergebruik op het werk als het probleemoplossend vermogen hoger ligt naarmate het opleidingsniveau van werkenden in beroepen hoger is.

FIGUUR 4.1 Relatie tussen computergebruik en probleemoplossend vermogen, en relatieve groei van beroepen, naar opleidingsniveau van de beroepen
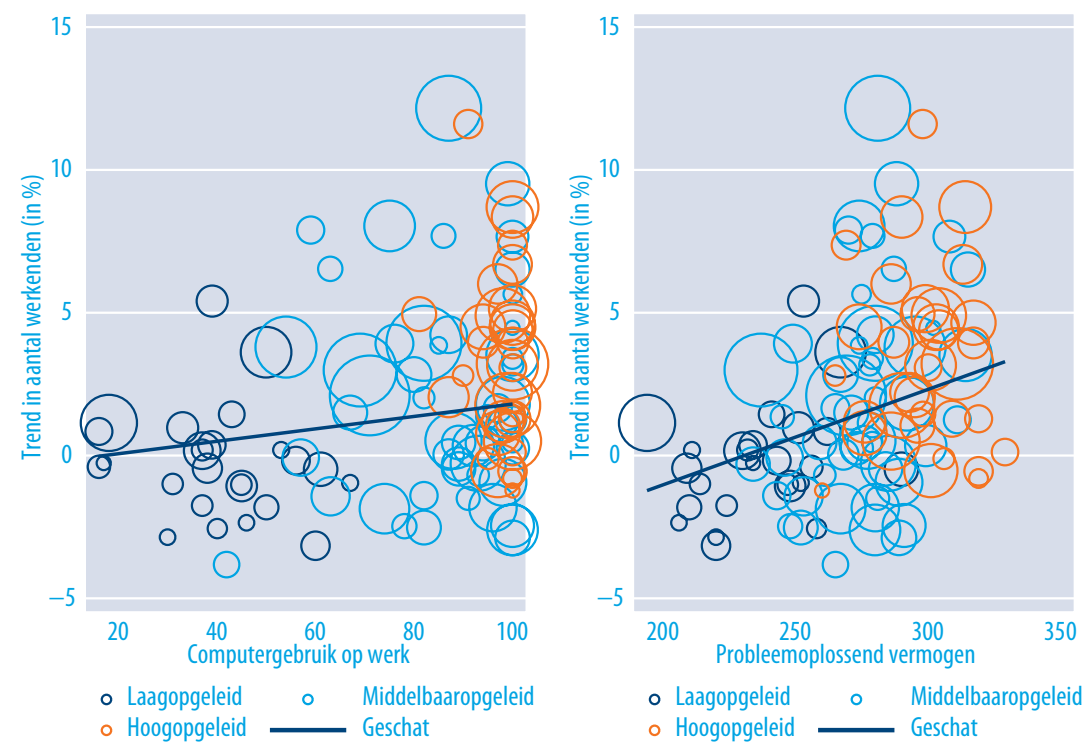

Bron: ROA (bewerking EBB en PIAAC)

Noot: de grootte van beroepen in aantal werkenden wordt weerspiegeld in de grootte van de cirkels

De loonontwikkeling van beroepen geeft ook een indicatie voor de mate waarin de werkgelegenheidsontwikkeling vraaggestuurd is. In figuur 4.2 is de relatie tussen de loonontwikkeling en de relatieve groei van het aantal werkenden in beroepen weergegeven. ${ }^{126}$ De figuur laat een positief verband zien tussen de loon- en werkgelegenheidsontwikkeling. De correlatie is significant op $5 \%$ en gelijk aan 0,19. Beroepen met een toename in loon hebben dus ook een positieve werkgelegenheidsontwikkeling door-

125 Opmerkelijk is wel dat deze correlatie niet opgaat als wij kijken naar de groei en krimp van beroepen in absolute termen. Dit suggereert dat relatief kleine opkomende beroepen die gekenmerkt zijn als beroepen met veel probleemoplossend vermogen in een digitale omgeving (en relatief klein verdwijnende beroepen die gekenmerkt zijn als probleemoplossend vermogen in een digitale omgeving) verantwoordelijk zijn voor dit verband.

126 De trend in loon (netto uurloon) is geschat op basis van data van het Arbeidsaanbodpanel voor de periode 1994-2010. In het Arbeidsaanbodpanel is de trend geschat voor de beroepen gecodeerd in de oude SBC classificatie. Door middel van een conversieschema van SBC naar BRC2014 is deze trend berekend voor de nieuwe ROA/CBS beroepenindeling. 
gemaakt. Het CPB heeft de relatie tussen de loon- en werkgelegenheidsontwikkeling in Nederland nader onderzocht en concludeert dat zowel de werkgelegenheid alsook de lonen in het middensegment recentelijk gedaald zijn in Nederland, en schrijven dit toe aan de opkomst van de ICT. ${ }^{127}$ Toch is deze trend met betrekking tot de lonen en de werkgelegenheid van het middensegment vergeleken met andere landen relatief klein. De afname van zowel de werkgelegenheid als de lonen van middelbaar opgeleiden suggereert dat er sprake is van een vraaggestuurde afname van de werkgelegenheid in beroepen op middelbaar niveau.

\section{FIGUUR 4.2 Relatie tussen loonontwikkeling en relatieve groei van beroepen}

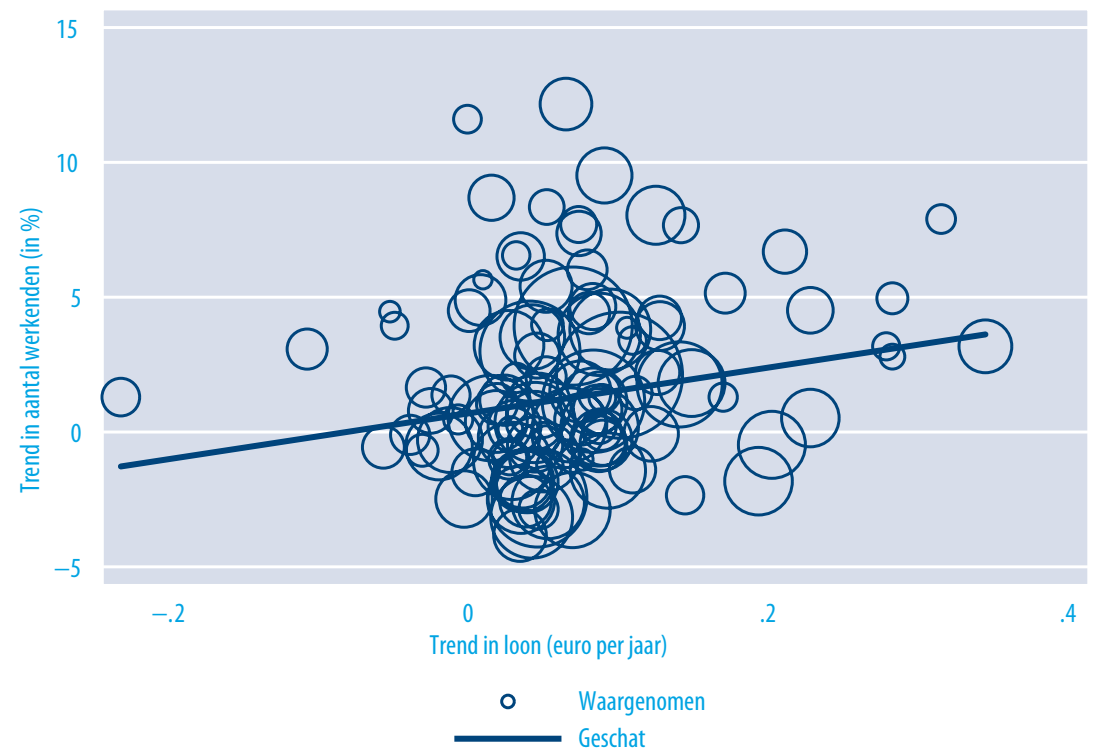

Bron: ROA (bewerking EBB en Arbeidsaanbodpanel)

Noot: de grootte van beroepen wordt weerspiegeld in de grootte van de cirkels

\subsection{Opleidingsstructuur van beroepen 1996-2014}

In figuur 4.3 wordt voor de periode 1996-2014 weergegeven hoe het opleidingsniveau van de werkende beroepsbevolking zich heeft ontwikkeld. Hiertoe is per beroep gekeken naar de mediaan van de opleidingsniveaus binnen beroepen: vmbo, mbo, hbo of wo. Per jaar is vervolgens de verdeling van de werkenden per modaal opleidingsniveau van het beroep weergegeven. In 1996 was 27,8 procent van de werkenden werkzaam in een beroep waarvan het modaal opleidingsniveau vmbo was. Dit percentage neemt trendmatig af tot 10,8 in 2014. Het aandeel werkenden met een mbo-, hbo- en

127 Van den Berge en ter Weel (2015), Middensegment onder druk. Nieuwe kansen door technologie, CPB Policy Brief 2015/13. 
wo-opleiding is in dezelfde periode gestegen. ${ }^{128}$ Deze stijging vindt met name plaats op het hbo: van $15,8 \%$ in 1996 tot $25,2 \%$ in 2014. Het percentage werkenden op mbo is in dezelfde periode gestegen van $53,3 \%$ tot $59,3 \%$. Voor het wo is een stijging van $3,1 \%$ in 1996 tot 4,6\% in 2014 waargenomen.

FIGUUR 4.3 Verdeling van de werkenden naar het mediaan opleidingsniveau van hun beroep, 1996-2014

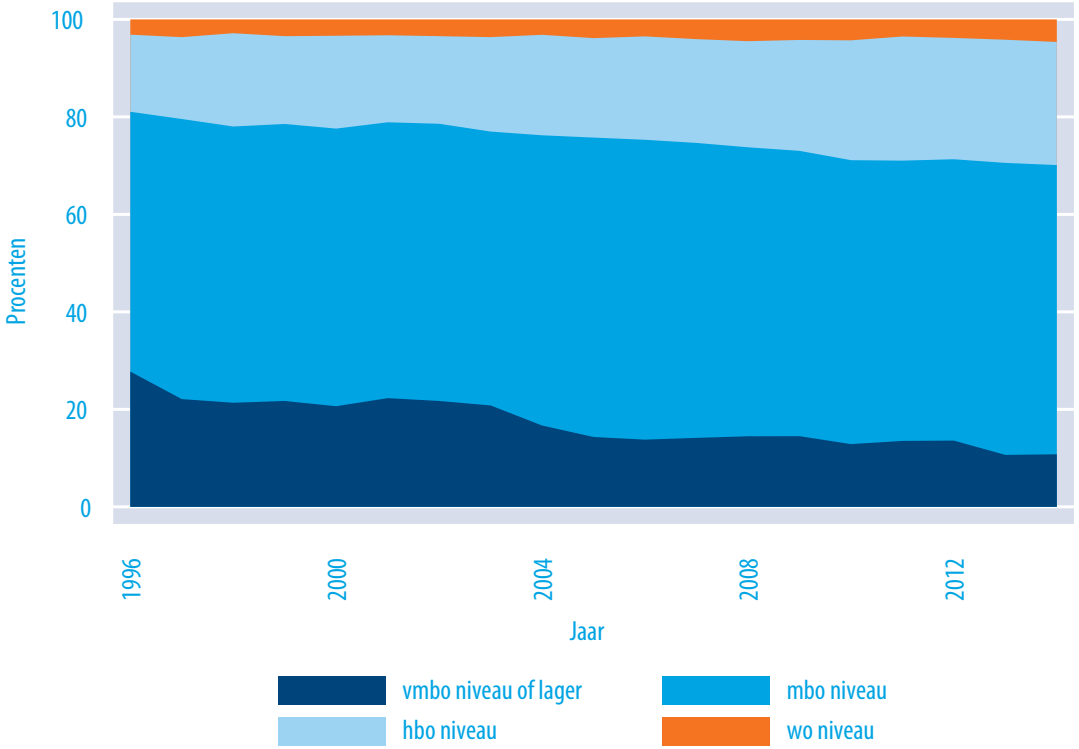

Bron: ROA (bewerking EBB)

Met een shift-share analyse kan op een systematische manier onderzocht worden in welke mate veranderingen in het gemiddelde opleidingsniveau van de werkenden (GON) het gevolg zijn van verschuivingen in de beroepenstructuur (structuureffect) of van veranderingen in de opleidingseisen binnen beroepen (verdringings- of substitutieeffect). ${ }^{129,130}$

Uit figuur 4.3 is nog niet duidelijk of de stijging van het gemiddelde opleidingsniveau van werkenden het gevolg is van verschuivingen in de beroepenstructuur of van

128 Dit is in tegenstelling tot de bevindingen in I. Bijlsma, S. Dijksman, D. Fouarge, A. Künn-Nelen (2015), Winnaars en verliezers op de arbeidsmarkt 1996-2012, Tijdschrift voor Arbeidsvraagstukken, 31(2): 106-123. Daar werd gevonden dat het percentage werkenden in beroepen op mbo niveau het meest afneemt. Het verschil in bevindingen is het gevolg van het gebruik van een andere beroepenclassificatie. Aan de aanbodkant is er overigens sprake van een structurele verschuiving binnen het mbo: het aanbod van werkenden op mbo 2-3 neemt structureel af, terwijl het aanbod op mbo 4 toeneemt.

129 Grip, A. de (1987), Winnaars en verliezers op de arbeidsmarkt 1981-1985, Tijdschrift voor Arbeidsvraagstukken, 3, 61-69.

130 Er kan daarnaast sprake zijn van een, doorgaans klein, interactie-effect dan de gevolgen van simultane verschuivingen in de beroepenstructuur aangeeft en dat wij hier niet rapporteren. 
hogere aanstellingseisen binnen de verschillende beroepsgroepen. In tabel 4.3 wordt daarom voor de periode 1996-2014 niet alleen het gemiddeld opleidingsniveau aan het begin en het eind van de periode weergegeven, maar wordt de verandering in opleidingsniveau door middel van een shift-share analyse verdeeld naar een structuur- en substitutie-effect. ${ }^{131}$ De gevolgen van de verschuivingen in de beroepenstructuur voor het gemiddelde opleidingsniveau bestempelen we als het structuureffect (shift), en verschuivingen van het gemiddelde opleidingsniveau binnen een beroepsgroep als het verdringings- of substitutie-effect (share). De tabel bevestigt dat er sprake is van een stijgend opleidingsniveau van de beroepsbevolking (totaal effect), en dat dit vooral het gevolg is van verschuivingen van het gemiddelde opleidingsniveau binnen beroepsgroep (substitutie-effect).

TABEL 4.3 Verandering van het gemiddelde opleidingsniveau (GON), opgedeeld in een structuuren substitutie-effect, 1996-2014

\begin{tabular}{|l|r|r|r|r|r|}
\hline Periode & GON 1996 & GON 2014 & $\begin{array}{r}\text { Totaal- } \\
\text { effect }\end{array}$ & $\begin{array}{r}\text { Structuur- } \\
\text { effect }\end{array}$ & $\begin{array}{r}\text { Substitutie- } \\
\text { effect }\end{array}$ \\
\hline $1996-2014$ & 5,74 & 6,54 & 0,79 & 0,33 & 0,52 \\
\hline
\end{tabular}

Bron: ROA (bewerking EBB)

Over de periode 1996-2014 is het totaaleffect 0,79. Dit wil zeggen dat in 2014 het gemiddelde opleidingsniveau van de werkenden 0,79 opleidingsjaar hoger was dan in 1996. Het substitutie-effect is in de totale periode groter dan het structuureffect. Dit wil zeggen dat de toename in het gemiddelde opleidingsniveau meer het gevolg is van hogere opleidingseisen per beroepsgroep, dan van verschuivingen in de beroepenstructuur. Toch mag ook de omvang van het structuureffect niet onderschat worden. Met 0,33 opleidingsjaar betekent dit dat ruim $40 \%$ van de skills upgrading resulteert uit verschuivingen in de beroepenstructuur. Het is echter belangrijk om op te merken dat stijging van het opleidingsniveau van de werkenden over de jaren heen langzaam afneemt. Zo laten wij elders zien dat het totaal-effect van de verandering in het gemiddelde opleidingsniveau het grootst was in de periode 1981-1985 en dat dit effect kleiner wordt in opeenvolgende 5 -jaars perioden. ${ }^{132}$ Zo was het totaal-effect gelijk aan 0,47 opleidingsjaar in de periode 1981-1985 maar slechts 0,19 opleidingsjaar in de periode 2005-2010.

\section{Veranderende opleidingsstructuur naar beroepsklasse}

In tabel 4.4 is dezelfde exercitie uitgevoerd per beroepsklasse en de tabel laat een interessante heterogeniteit tussen de beroepsklassen zien. Zo blijkt dat het gemiddeld opleidingsniveau onder de pedagogische beroepen tussen 1996 en 2014 licht is afgenomen

131 Met een shift-share analyse kan op een systematische manier onderzocht worden in welke mate veranderingen in het opleidingsniveau van de werkenden het gevolg is van verschuivingen in de beroepenstructuur (structuureffect) of van veranderingen in de opleidingseisen binnen beroepen (verdringings- of substitutieeffect). Er kan daarnaast sprake zijn van een, doorgaans klein, interactie-effect dat de gevolgen van simultane verschuivingen in de beroepenstructuur aangeeft en dat wij hier niet rapporteren.

132 Voor een beschrijving van de ontwikkelingen in tussenliggende periodes, zie: I. Bijlsma, S. Dijksman, D. Fouarge, A. Künn-Nelen (2015), Winnaars en verliezers op de arbeidsmarkt 1996-2012, Tijdschrift voor Arbeidsvraagstukken, 31(2): 106-123. 
met 0,26 opleidingsjaar. ${ }^{133}$ Dit blijkt met name het gevolg te zijn van verschuivingen in de beroepenstructuur, met andere woorden er is in 2014 meer werkgelegenheid in lagere pedagogische beroepen dan in 1996. Ook voor de creatieve en taalkundige beroepen observeren we een afname in het gemiddeld opleidingsniveau. ${ }^{134}$ Dit blijkt echter voornamelijk het gevolg te zijn van een substitutie-effect. Binnen de creatieve en taalkundige beroepen zijn de opleidingseisen gedurende de periode 1996-2014 dus naar beneden bijgesteld. De overige beroepsklassen hebben allemaal te maken met upgrading. Twee van deze beroepsklassen hebben desalniettemin een negatief structuureffect, wat wil zeggen dat de beroepenstructuur een verschuiving naar lagere beroepen heeft doorgemaakt. Dit geldt met name voor de managers. Het substitutie-effect, de toenemende opleidingseisen binnen de beroepsgroepen, overstijgt voor deze beroepen ruimschoots het structuureffect waardoor het totaaleffect alsnog positief is. Met uitzondering van de pedagogische beroepen geldt dat voor alle beroepsklassen het substitutie-effect groter is dan het structuureffect. Dit wil zeggen dat het hogere gemiddelde opleidingsniveau voor een groter deel te wijten is aan hogere opleidingseisen binnen beroepen dan aan een verschuiving naar beroepen met een lager opleidingsniveau. Voor vrijwel alle beroepsklassen (met uitzondering van de eerder genoemde pedagogische en creatieve en taalkundige beroepen) geldt dus een skills upgrading.

TABEL 4.4 Verandering van het gemiddelde opleidingsniveau (GON), verbijzonderd naar beroepsklassen, opgedeeld in een structuur- en substitutie-effect, 1996-2014

\begin{tabular}{|l|r|r|r|r|r|}
\hline Beroepsklassen (shift-share 2014) & GON 1996 & GON 2014 & $\begin{array}{r}\text { Totaal- } \\
\text { effect }\end{array}$ & $\begin{array}{r}\text { Structuur- } \\
\text { effect }\end{array}$ & $\begin{array}{r}\text { Substitutie- } \\
\text { effect }\end{array}$ \\
\hline Pedagogische beroepen & 8,66 & 8,41 & $-0,26$ & $-0,26$ & $-0,02$ \\
\hline Creatieve en taalkundige beroepen & 8,37 & 8,14 & $-0,23$ & $-0,06$ & $-0,15$ \\
\hline Commerciële beroepen & 5,22 & 5,96 & 0,74 & 0,20 & 0,46 \\
\hline Bedrijfseconomische en administratieve beroepen & 6,25 & 7,22 & 0,97 & 0,41 & 0,63 \\
\hline Managers & 7,08 & 8,16 & 1,08 & $-0,35$ & 0,71 \\
\hline Openbaar bestuur, veiligheid en juridische beroepen & 6,97 & 7,62 & 0,65 & 0,08 & 0,53 \\
\hline Technische beroepen & 4,89 & 5,60 & 0,71 & 0,33 & 0,41 \\
\hline ICT-beroepen & 7,65 & 8,28 & 0,63 & 0,05 & 0,58 \\
\hline Agrarische beroepen & 4,20 & 4,74 & 0,55 & $-0,04$ & 0,73 \\
\hline Zorg- en welzijnsberoepen & 7,15 & 7,58 & 0,43 & 0,22 & 0,18 \\
\hline Dienstverlenende beroepen & 4,02 & 4,66 & 0,64 & 0,04 & 0,60 \\
\hline Transport en logistiek beroepen & 3,55 & 4,06 & 0,51 & 0,02 & 0,56 \\
\hline
\end{tabular}

Bron: ROA (bewerking EBB)

Een toename in het gemiddelde opleidingsniveau kan zowel vraag als aanbod gerelateerd zijn. Er hebben zich sinds 1996 verschillende ontwikkelingen aan de aanbodkant van de arbeidsmarkt voorgedaan die aan een stijging van het gemiddeld opleidingsni-

133 Het is belangrijk op te merken dat voor twee pedagogische beroepen, namelijk de leerkrachten basisonderwijs en de leidsters kinderopvang en onderwijsassistenten, het gemiddeld opleidingsniveau (GON) juist is toegenomen.

134 Ook hier zijn weer twee uitzonderingen: voor de bibliothecarissen en conservatoren, en de journalisten observeren we een toename in het gemiddeld opleidingsniveau. 
veau hebben bijgedragen. Voorbeelden zijn demografische ontwikkelingen, veranderingen in de preferenties en opleidingskeuze van leerlingen en veranderde kenmerken van leerlingen en studenten zoals een toename van het aantal vrouwen in het hoger onderwijs. ${ }^{135}$ Aan de vraagkant van de arbeidsmarkt wordt skill-biased technological change vaak genoemd, ${ }^{136}$ maar ook globalisering ${ }^{137}$ en organisatorische veranderingen. ${ }^{138}$ De organisatorische veranderingen die leiden tot een toename in het opleidingsniveau kunnen in drie categorieën worden verdeeld: decentralisatie, ${ }^{139}$ teamwork ${ }^{140}$ en een verandering van het takenpakket bestaande uit meer (complexe) taken en functieroulatie. ${ }^{141}$ Deze ontwikkelingen dragen op verschillende manieren bij aan het structuuren substitutie-effect. Terwijl globalisering vooral leidt tot een negatief structuureffect, kunnen technologische en organisatorische veranderingen zowel leiden tot een structuur- als een substitutie-effect.

\subsection{Leeftijdssamenstelling van beroepsgroepen 1996-2014}

Ook de leeftijdsstructuur van de werkenden is veranderd in de periode 1996-2014. Zo bestond in 1996 nog 31,0\% van de werkenden uit personen jonger dan dertig jaar, maar is dit in 2014 gedaald tot $24,9 \%$. Het percentage 55 -plussers maakte in diezelfde tijd een substantiële groei door (van 7,0\% in 1996 tot 18,1\% in 2014) en het ligt in de lijn der verwachtingen dat dit percentage de komende jaren nog verder toeneemt. ${ }^{142}$

In figuur 4.4 is de leeftijdsverdeling van de werkenden naar beroepsklasse en geslacht in 1996 (kleurvulling) en in 2014 (contour) weergegeven (bijlage D laat deze leeftijdspiramide zien naar opleidingsniveau). ${ }^{143}$ Uit het figuur blijkt allereerst dat mannen en vrouwen niet evenredig verdeeld zijn over de verschillende beroepsklassen. Voor sommige beroepsklassen zien we dat dit genderverschil ook alleen maar is toegenomen (bijvoorbeeld pedagogische en agrarische beroepen). Ook zien we in het figuur dat bepaalde beroepsklassen gegroeid zijn. Hier gaat het om managers, zorg-

135 Winden, P. de (2011), Steeds meer jongeren volgen hoger onderwijs, Den Haag/Heerlen CBS, Webmagazine.

136 Katz, L. \& Autor, D. (1999), Changes in the wage structure and earnings inequality, In O. Ashenfelter \& D. Card (red.), Handbook of Labor Economics, vol. 3 (pp. 1463-1555), Amsterdam: Elsevier.

137 Wood, A. (1994), North-South trade, employment, and inequality: changing fortunes in a skill-driven world, Oxford: Clarendon Press; Manasse, P., Stanca, L. \& Turrini, A. (2004), Wage premia and skill upgrading in Italy: why didn't the hound bark? Labour Economics, 11, 59-83.

138 Caroli, E., \& Van Reenen, J. (2001), Skill-biased organizational change? Evidence from a panel of British and French establishments, Quarterly Journal of Economics, 1449-1492.

139 Brynjolfsson, E. \& Mendelson, H. (1993), Information systems and the organization of modern enterprise, Journal of Organizational Computing, 3, 245-255; Bresnahan, T. (1999), Computerisation and wage dispersion: an analytical reinterpretation, Economic Journal, 109, 390-415.

140 Osterman, P. (1994), How common is workplace transformation and who adopts it? Industrial and Labour Relations Review, 47, 173-188.

141 Greenan, N. \& Mairesse, K. (1999), Organizational change in French manufacturing: what do we learn from firm representatives and from their employees? NBER Working Paper 7285; Ichniowski, C. \& Shaw, K. (2003), Beyond incentive pay: insiders' estimates of the value of complementary Human Resource Management Practices. Journal of Economic Perspectives, 17, 155-180.

142 Grip, A. de, D. Fouarge \& R. Montizaan (2013), How sensitive are individual retirement expectations to raising the retirement age? De Economist, 161(3): 225-251.

143 Het verschil tussen mannen en vrouwen is gemaakt omdat in het model waarin de vervangingsvraag geschat wordt eenzelfde onderscheid gemaakt wordt. 
en welzijnsberoepen en ICT-beroepen. ${ }^{144}$ De voornaamste bevinding van figuur 4.4 is echter de verschuiving in de leeftijdsstructuur van de beroepsklassen. Voor vrijwel alle beroepsklassen zien we dat er in 2014 (t.o.v. 1996) meer werkenden zijn (zowel vrouwen als mannen) in de leeftijden vanaf 55 . De enige uitzondering hierop zijn de agrarische beroepen: daar werken minder 55-plussers in 2014 dan in 1996. Dit is een gevolg van de structurele daling van de werkgelegenheid binnen de agrarische sector.

FIGUUR 4.4 Leeftijdsverdeling van de werkenden naar beroepsklasse en geslacht, 1996-2014, aantal werkenden naar leeftijd, 1996 en 2014

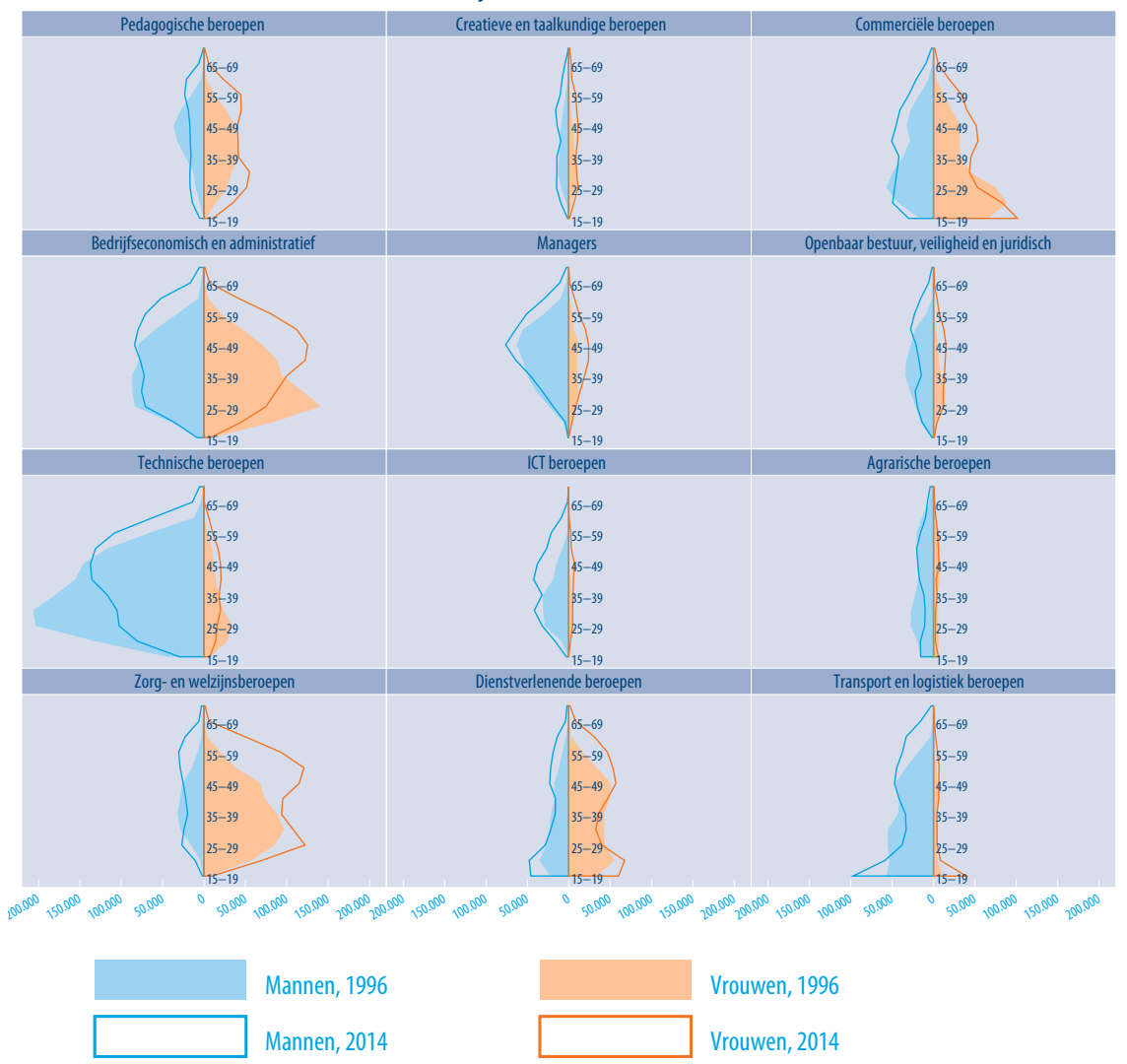

Bron: ROA (bewerking EBB)

Voor een aantal beroepsklassen observeren we naast vergrijzing ook ontgroening: het aantal werkenden jonger dan dertig jaar lag in 2014 onder het aantal van 1996, hetgeen wijst op een lagere instroom in die beroepen door jongeren, en mogelijk dus ook een lage vervangingsbehoefte. Dit is het geval bij de bedrijfseconomische en administra-

144 Dat deze beroepsklassen niet oververtegenwoordigd zijn in tabel 4.1 heeft te maken met het verschil in relatieve groei (tabel 4.1) en absolute (figuur 4.4) werkgelegenheidsgroei. 
tieve beroepen, managers, openbaar bestuur, veiligheid en juridische beroepen, agrarische beroepen, maar bovenal bij de technische beroepen.

Een groot deel van de vervangingsvraag betreft de vervanging van mensen die met pensioen gaan. Echter, vervanging is alleen nodig als de werkgelegenheid in de desbetreffende beroepen stabiel is of groeit. Een krimpend beroep met veel uitstroom behoeft doorgaans geen vervanging. Door terug te kijken naar de periode 1996-2014 kunnen we zien of er een samenhang is tussen het percentage ouderen en de werkgelegenheidsontwikkeling binnen beroepen met een bepaald opleidingsniveau. In figuur 4.5 wordt hiertoe de relatie tussen het percentage 55-74 jarigen en de relatieve groei van beroepen weergegeven. ${ }^{145} \mathrm{Er}$ blijkt geen eenduidige relatie te bestaan. Alleen voor de laagopgeleide beroepen vinden we een significant negatief verband. Dit wil zeggen dat voor de laagopgeleide beroepen geldt dat een hoog percentage ouderen in 1996 gerelateerd is aan een werkgelegenheidsafname. Met andere woorden, de laagopgeleide beroepen met een hoog percentage ouderen in 1996 lijken te krimpen. Een dergelijk verband wordt niet gevonden voor middelbaar of hoog opgeleide beroepen.

\section{FIGUUR 4.5 Relatie tussen percentage 55-74 jarigen en de relatieve groei van beroepen, naar opleidingsniveau van de werkenden in beroepen}

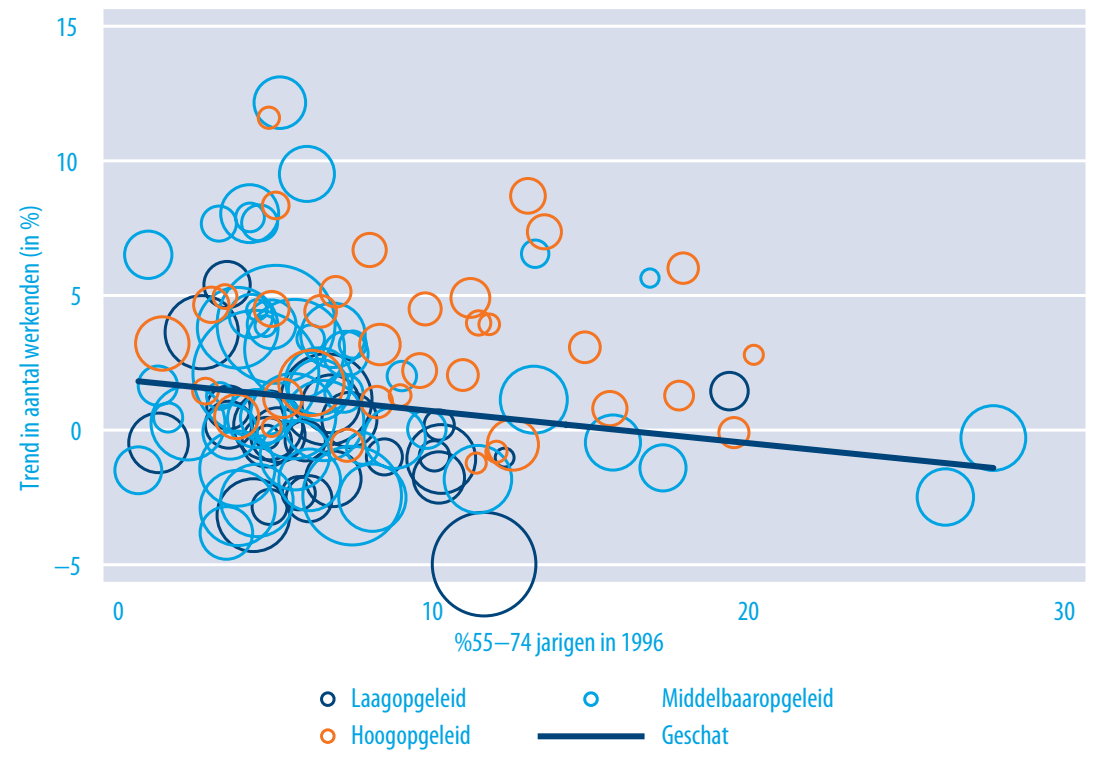

Bron: ROA (bewerking EBB)

Ten slotte wordt in figuur 4.6 per beroep aangegeven in hoeverre het gemiddelde opleidingsniveau van de ouderen (55-74 jaar) in 2014 zich verhoudt tot dat van jongeren (15-30 jaar). Dit illustreert kwalitatieve aspecten van de vervangingsbehoefte. Gezien de eerder in dit hoofdstuk waargenomen skills upgrading (voor het grootste deel het gevolg

145 In figuur 4.5 is gekozen om ouderen te definiëren als 55+ers omdat we terugkijken naar de jaren 1996-2014. 
van een positief substitutie-effect, zie paragraaf 4.3), is het te verwachten dat ouderen binnen beroepsgroepen minder hoog opgeleid zijn dan de jongeren. Als gevolg hiervan verwachten we dat de beroepgroepen zich over het algemeen onder de weergegeven 45-graden lijn bevinden. Dit blijkt ook voor het merendeel van de beroepsgroepen het geval te zijn (72 van 114 beroepsgroepen). Er is een aantal uitzonderingen waarin het gemiddelde opleidingsniveau van de ouderen 1 jaar of meer hoger ligt dan dat van de jongeren. Het betreft docenten hoger onderwijs en hoogleraren, managers zorginstellingen, militaire beroepen, beeldend kunstenaars, onderwijskundigen en overige docenten, en procesoperators.

De observatie dat de jongeren over het algemeen hoger opgeleid zijn dan de ouderen binnen een beroepsgroep is belangrijk voor de berekening van de vervangingsvraag naar opleiding. Het is belangrijk dat in de prognoses voor de vervangingsvraag rekening wordt gehouden met deze waargenomen skills upgrading. Dit wordt gedaan sinds de vorige editie van 'De arbeidsmarkt naar opleiding en beroep.'146

FIGUUR 4.6 Opleidingssamenstelling van jong en oud binnen beroepen, naar opleidingsniveau van werkenden in beroepen

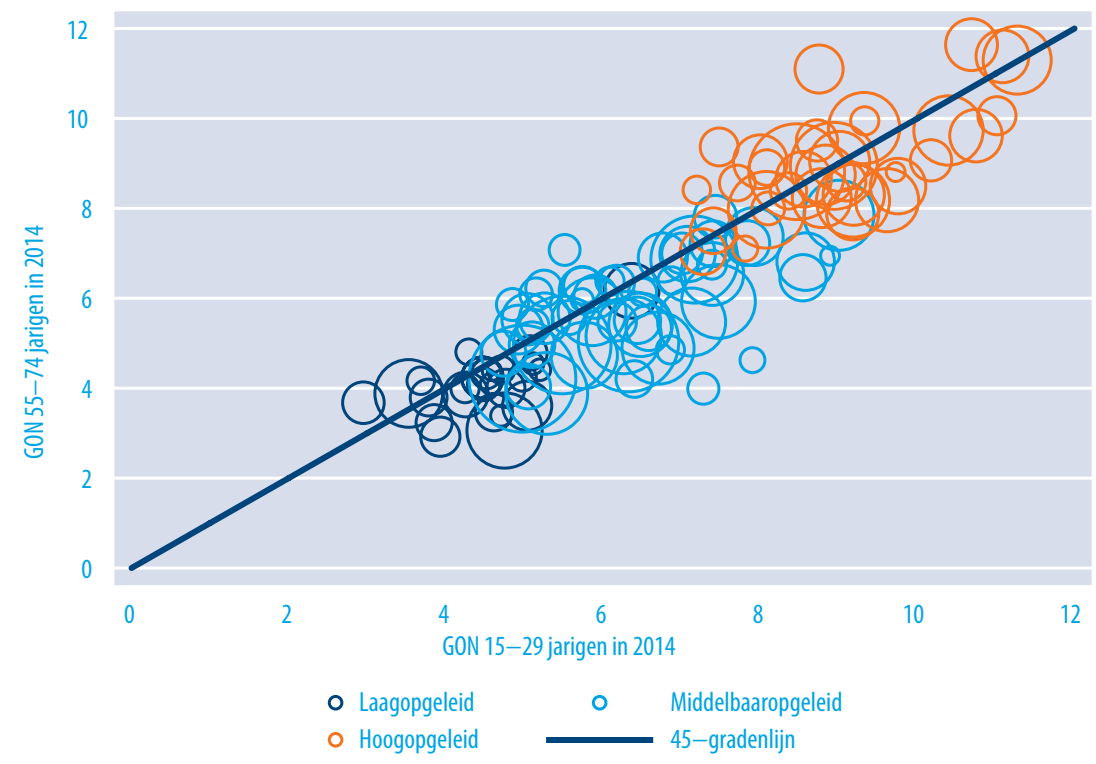

Bron: ROA (bewerking EBB)

146 ROA (2013), De arbeidsmarkt naar opleiding en beroep tot 2018, Maastricht: ROA-R-2013/11. 


\subsection{Conclusie}

In dit hoofdstuk is een overzicht gegeven van de beroepenstructuur in de periode 19962014. Daarbij is eerst gekeken naar de top 10 relatieve groei- en krimpberoepen in de periode 1996-2014 en naar de verschillen in het modale opleidingsniveau over de jaren. Terwijl de top 10 groeiberoepen bestaat uit enkel hbo- en mbo-beroepen, bevinden zich in de top 10 krimpberoepen uitsluitend mbo- en vmbo-beroepen. ${ }^{147}$ De meeste groeiberoepen betreffen pedagogische beroepen. De krimpberoepen daarentegen zijn veelal beroepen in de techniek. Op basis van PIAAC-data blijkt bovendien dat de werkgelegenheidsgroei significant en positief samenhangt met het niveau van probleemoplossend vermogen in een digitale omgeving van werkenden in die beroepen. Dit suggereert dat complex informatiegebruik en informatieverwerking steeds belangrijker worden.

Vervolgens is er gekeken naar de verschuivingen in de opleidingsstructuur van beroepen. Over de gehele periode is een positief totaaleffect te zien van het gemiddelde opleidingsniveau. Dit verschilt echter per beroepsklasse, en er is voor de pedagogische en creatieve en taalkundige beroepen juist een negatieve trend zichtbaar. ${ }^{148}$ Daarnaast hebben we de verandering in de leeftijdsstructuur binnen beroepen geanalyseerd. Daarin zien we een geleidelijke vergrijzing van de beroepen, en een mate van skills upgrading onder de jongeren die werken ten opzichte van de ouderen in hun vakgebied.

Deze bevindingen samen duiden op een kennisintensivering van de economie. Hoewel er zowel sprake is van een verschuiving van beroepen met lage naar beroepen met hoge opleidingseisen, vindt de kennisintensivering met name binnen beroepen plaats in plaats van tussen beroepen. Met andere woorden, de opleidingseisen voor beroepen zijn de afgelopen decennia over het algemeen gestegen. Dit is ook te zien doordat voor vrijwel alle beroepen geldt dat het opleidingsniveau van jongeren hoger is dan onder ouderen met hetzelfde beroep. Het is dus belangrijk om in de vervangingsvraag naar opleiding rekening te houden met deze zogenaamde skills-upgrading. Het is overigens belangrijk om op te merken dat de stijging van het opleidingsniveau van de werkenden over de jaren heen langzaam afneemt. ${ }^{149}$

Is er sprake van polarisatie op de Nederlandse arbeidsmarkt? In een recente studie laat het CPB zien dat het aandeel laag- en hoogbetaalden tussen 1999 en 2014 is gestegen ten koste van het middensegment. ${ }^{150}$ De cijfers die in dit hoofdstuk gepresenteerd zijn, hebben betrekking op de verschuivingen in de opleidingsstructuur binnen en tussen

147 Echter, tussen 1996 en 2014 heeft er een significante afname plaatsgevonden in het aantal mensen werkzaam in beroepen waarvan het modaal opleidingsniveau vmbo was. Tegelijkertijd steeg het aantal werkenden met een mbo-, wo- en met name hbo-opleiding.

148 Er zijn uitzonderingen in onderliggende pedagogische en creatieve beroepen waar wel een toename in het gemiddeld opleidingsniveau waargenomen wordt zoals leraren basisonderwijs en journalisten. Zie voetnoten 130 en 131.

149 I. Bijlsma, S. Dijksman, D. Fouarge, A. Künn-Nelen (2015), Winnaars en verliezers op de arbeidsmarkt 1996-2012, Tijdschrift voor Arbeidsvraagstukken, 31(2): 106-123.

150 Van den Berge, W. en B. ter Weel (2015), Middensegment onder druk. Nieuwe kansen door technologie, CPB Policy Brief 2015/13. 
beroepen, maar laten geleidelijke veranderingen zien. Het is goed om te beseffen dat middelbaar opgeleiden niet altijd werkzaam zijn in beroepen die qua beloning tot het middensegment behoren: sommige middelbaar opgeleiden werken in hoogbetaalde beroepen en een deel werkt in laagbetaalde beroepen. ${ }^{151}$ Daarnaast blijkt dat het aandeel middelbaar opgeleiden in laagbetaalde beroepen stijgt. Bovendien lijkt de discussie rond polarisering op de arbeidsmarkt genuanceerder te zijn dan de sterke tegenstelling tussen wel of geen polarisatie aanvankelijk doet vermoeden. In een in de zomer van 2015 gepubliceerde bijdrage stelt arbeidseconoom David Autor te verwachten dat de arbeidsmarkt niet volledig zal polariseren. ${ }^{152}$ Dit komt doordat banen bestaan uit bundelingen van taken die niet altijd gemakkelijk uit elkaar getrokken kunnen worden waarbij bijvoorbeeld routinematige aspecten van banen op middelbaar niveau geautomatiseerd kunnen worden en de resterende niet-routinematige aspecten uitgevoerd kunnen worden door lager opgeleiden. We weten momenteel echter betrekkelijk weinig over de takensamenstelling van banen waardoor verder onderzoek noodzakelijk is. Daarnaast kan worden verwacht dat technologische ontwikkelingen tot nieuwe werkgelegenheid zal leiden, ook in het middensegment, waar een groeiend beroep gedaan wordt op interactieve en sociale vaardigheden. ${ }^{153}$

151 Van den Berge, W. en B. ter Weel (2015, te verschijnen), De impact van technologische verandering op de Nederlandse arbeidsmarkt, 1999-2014.

152 Autor, D. (2015), Why are there still so many jobs? The history and future of workplace automation, Journal of Economic Perspectives, 29 (3): 3-30.

153 Zie voetnoot 149. 



\section{5 \\ ARBEIDSMARKTPOSITIE EN -PERSPEC- TIEVEN VAN ARBEIDSGEHANDICAPTEN}

\subsection{Inleiding}

Arbeidsgehandicapten kunnen worden beschouwd als een kwetsbare groep op de arbeidsmarkt. ${ }^{154}$ In 2013 is bijna 15,8\% van de arbeidsgehandicapten in de beroepsbevolking werkloos. ${ }^{155}$ Dit is gelijk aan het werkloosheidspercentage onder mannen en vrouwen die enkel basisonderwijs hebben genoten. ${ }^{156}$ Ook vóór de crisis was het percentage werkloze arbeidsgehandicapten hoog in vergelijking met de niet-arbeidsgehandicapten (respectievelijk $10,4 \%$ en $4,9 \%$ in 2006). Echter, tijdens de crisis is de werkloosheidskloof tussen arbeidsgehandicapten en niet-arbeidsgehandicapten verder gegroeid: het verschil in werkloosheidspercentage bedroeg 5,5 procentpunten voor de crisis tegen 8,2 procentpunten in 2013.

Naar verwachting zal in de komende jaren het aanbod van arbeidsgehandicapten op de 'reguliere' arbeidsmarkt als gevolg van beleidsmaatregelen stijgen. Vanaf 1 januari 2015 is de Participatiewet in werking getreden, waarmee arbeidsgehandicapten met arbeidsvermogen zoveel mogelijk worden gestimuleerd betaalde arbeid te verrichten; bij voorkeur bij een reguliere werkgever. In het sociaal akkoord hebben werkgevers afgesproken dat zij 100.000 extra banen zullen creëren voor mensen met een arbeidsbeperking (tot 2026). Daarnaast worden nog 25.000 banen gecreëerd door de overheid. ${ }^{157}$ Naast deze macroafspraak wordt door de quotumregeling per individuele werkgever gekeken of hij voldoende banen voor arbeidsgehandicapten heeft gerealiseerd. ${ }^{158}$ De Eerste Kamer heeft de 'Wet banenafspraak en quotum arbeidsbeperkten' op 31 maart 2015 aangenomen.

Een toename in het aanbod van arbeidsgehandicapten op de arbeidsmarkt wil echter nog niet zeggen dat zij ook daadwerkelijk werkzaam zullen zijn. Allereerst speelt de

154 Dit hoofdstuk is tot stand gekomen in het kader van een samenwerkingsproject met CBS. ROA bedankt Henk-Jan Dirven, Hendrika Lautenbach en Martine Mol van CBS voor het beschikbaar maken van de benodigde gegevens.

155 Hierbij is uitgegaan van de 12-uursdefinitie van de beroepsbevolking.

156 CBS Statline, 2014.

157 Rijksoverheid met Kamerbrief over Participatiewet en quotum na sociaal akkoord, 27 juni 2013

158 Zie voor meer informatie over de banenafspraak en de quotumwet: http://www.rijksoverheid.nl/documenten-en-publicaties/kamerstukken/2014/07/01/wetsvoorstel-banenafspraak-en-quotum-arbeidsbeperkten.html 
vraag naar arbeid hierin een rol. Zoals in de rest van dit rapport naar voren is gekomen is de uitbreidingsvraag de komende jaren positief, wat wil zeggen dat er voor de meeste beroepsklassen een toename in de werkgelegenheid verwacht wordt. ${ }^{159}$ De confrontatie van de verwachte vraag en het verwachte aanbod zorgt voor goede perspectieven voor mensen met een opleiding in mbo 4 groen, hbo onderwijs, hbo techniek, hbo landbouw en natuur, wo techniek en wo landbouw en natuur (en een aantal meer specifieke opleidingstypes). In dit hoofdstuk zal bekeken worden in hoeverre de werkzame arbeidsgehandicapten vertegenwoordigd zijn in deze opleidingscategorieën en in de opleidingscategorieën waarvoor de arbeidsmarktperspectieven in het algemeen slechter zijn. Daarmee kan een indicatie gegeven worden voor de perspectieven van de arbeidsgehandicapten in de komende jaren.

Naast de vertegenwoordiging van arbeidsgehandicapten in opleidingscategorieën met goede of juist geringe perspectieven, zijn er verschillende theorieën die verklaren waarom arbeidsgehandicapten een lagere kans hebben op werk dan niet-arbeidsgehandicapten. ${ }^{160}$ Deze theorieën gaan in op de vraag- en/of aanbodkant van de arbeidsmarkt. ${ }^{161}$ Het menselijk kapitaal en de voorkeuren van arbeidsgehandicapten bepalen het aanbod van werk voor deze groep. Doorgaans hebben arbeidsgehandicapten minder werkervaring en een lager opleidingsniveau dan mensen zonder arbeidshandicap. ${ }^{162}$ Afhankelijk van hun handicap geven arbeidsgehandicapten vaak de voorkeur aan deeltijdwerk of aan flexibele werkomstandigheden. ${ }^{163}$ De vraag naar arbeidsgehandicapten wordt enerzijds bepaald door beleid en arbeidsmarktomstandigheden en anderzijds door (statistische) discriminatie vanuit de werkgever. Het is belangrijk op te merken dat beleid niet automatisch de werkgeversattitudes ten opzichte van arbeidsgehandicapten verbetert. Verschillende studies hebben aangetoond dat onder werkgevers een negatief beeld van arbeidsgehandicapten (lagere productiviteit en meer kosten door noodzakelijke aanpassingen) blijft bestaan. ${ }^{164}$ Onderzoek geeft aan dat dit een teken is dat de vormgeving van beleid niet effectief genoeg is. ${ }^{165}$

De theorie van statistische discriminatie verklaart het verschil in baankansen tussen arbeidsgehandicapten en niet-arbeidsgehandicapten vanuit de vraagkant van de

159 Zie tabel 2.1 in hoofdstuk 2.

160 Maroto and Pettinicchio (2014), Disability, structural inequality and work: The influence of occupational segregation on earnings for people with different disabilities, Research in Social Stratification and Mobility, 38 : 76-92.

161 Yelin and Trupin (2000), Succesfull labor market transitions for persons with disabilities: Factors affecting the probability of entering and maintaining employment, Research in Social Stratification and Mobility, 1: 105-129.

162 DeLeire (2001), Changes in wage discrimination against people with disabilities: 1984-93, Journal of Human Resources, 26, 114-58.

163 Maroto and Pettinicchio (2014), Disability, structural inequality and work: The influence of occupational segregation on earnings for people with different disabilities, Research in Social Stratification and Mobility, 38 : 76-92.

164 Schwochau and Blanck (2000), The economics of the Americans with Disabilities Act, Part III: Does the ADA disable the disabled? Berkeley Journal of Employment and Labor Law, 21 (271-313); Unger (2002) Employers' attitudes toward persons with disabilities in the workforce: Myths or realities? Focus on Autism and Other Developmental Disabilities, 17(1): 2-10.

165 Erken, Klokkenburg en Van der Werff (2014), Kan arbeidsmarktbeleid de positie van ouderen veranderen? TPEdigitaal, 8: 45-64. 
arbeidsmarkt. Volgens deze theorie hebben werkgevers mogelijk lage verwachtingen van prestaties en competenties van mensen met een arbeidshandicap als gevolg van (groep) generalisaties (stereotypen). Het wordt aangeduid als 'statistische' discriminatie omdat opvattingen en stereotypen zijn gebaseerd op een groepsgemiddelde. ${ }^{166}$ Deze verwachtingen zijn doorgaans negatief (gevoed door studies die de negatieve kanten van arbeidsgehandicapten in kaart brengen) wat de baankansen van arbeidsgehandicapten negatief beïnvloed. ${ }^{167}$ De labour queue theory veronderstelt dat arbeidsgehandicapten op basis van de verwachte trainingskosten en productiviteit doorgaans aan het eind van de rij van werkzoekenden staan en daarmee als laatst in aanmerking komen voor een baan. ${ }^{168}$ Deze theorie gaat er bovendien vanuit dat de arbeidsgehandicapten ok bepaalde voorkeuren hebben die bepalen of ze wel of niet solliciteren voor specifieke banen. De derde theorie - status characteristics theory - gaat ook uit van zowel de vraag- als aanbodkant van de arbeidsmarkt. Volgens deze theorie zorgen structurele condities ervoor dat bepaalde eigenschappen een waardeoordeel krijgen. Zowel werkgevers als arbeidsgehandicapten handelen vervolgens naar dit waardeoordeel. Ook als arbeidsgehandicapten wel aan het werk zijn/kunnen is het de vraag of zij een gelijke arbeidsmarktpositie hebben als niet-arbeidsgehandicapten. De hierboven beschreven theorieën verklaren niet alleen het verschil in baankansen tussen arbeidsgehandicapten maar ook de loonverschillen tussen beide groepen. ${ }^{169}$ Naast deze meest voorname arbeidsmarktuitkomsten (werk en loon) is het de vraag of arbeidsgehandicapten ook slechter scoren op subjectieve arbeidsmarktuitkomsten zoals inzetbaarheid, onderbenutting en kans op baanverlies.

In paragraaf 5.2 zullen we allereerst ingaan op de vraag in hoeverre arbeidsgehandicapten in 2013 aan het werk waren, en in welke sectoren, beroepen en in wat voor soort banen. Hiertoe zal enerzijds gebruik worden gemaakt van EBB-gegevens, welke vanwege de grote steekproefomvang en de specifieke gerichtheid op de arbeidssituatie van de Nederlandse bevolking zeer geschikt zijn. Anderzijds zal de Nationale Enquête Arbeidsomstandigheden (NEA) gebruikt worden om meer inzicht te verkrijgen in de aard van de ziekte of chronische aandoeningen van de arbeidsgehandicapten en het soort banen dat zij betrekken. ${ }^{170}$ In paragraaf 5.3 wordt gekeken naar de subjectieve arbeidsmarktuitkomsten van de werkende arbeidsgehandicapten (zoals onderbenutting en inzetbaarheid). Ook hiervoor is de NEA gebruikt. In paragraaf 5.4 wordt ingegaan

166 Arrow (1973), The theory of discrimination. In Ashenfelter and Rees (Eds.), Discrimination in labor markets (3-33), Princeton, NJ: Princeton University Press.

167 Domzal et al. (2008), Survey of employmer perspectives on the employment of people with disabilities technical report (prepared under contract to the Office of Disability and Employment Policy, U.S. Department of Labor). McLean, VA: CESSI.

168 Thurow, L. (1975), Generating Inequality: Mechanisms of Distribution in the U.S. Economy, New York: Basic Books.

169 Maroto and Pettinicchio (2014), Disability, structural inequality and work: The influence of occupational segregation on earnings for people with different disabilities, Research in Social Stratification and Mobility, 38: 76-92.

170 In de Nationale Enquête Arbeidsomstandigheden (NEA) van TNO en CBS werden tot en met 2013 jaarlijks jaarlijks circa 25.000 werknemers uitgebreid bevraagd over hun arbeidsomstandigheden en arbeidsmarktsituatie. Onder deze groep respondenten bevinden zich ongeveer 2.000 arbeidsgehandicapten (8\%). Van hen is bekend wat voor soort arbeidshandicap zij hebben. Vanaf 2014 is de steekproef van de NEA vergroot en worden jaarlijks circa 40.000 werknemers geënquêteerd. 
op de toekomstige arbeidsmarktperspectieven van arbeidsgehandicapten, waarbij wordt nagegaan in hoeverre arbeidsgehandicapten afkomstig zijn uit of in aanmerking komen voor kansrijke(re) - dan wel kansarme - beroepen. ${ }^{171}$ Hiertoe zal een link worden gelegd tussen de opleidingsachtergrond van de arbeidsgehandicapten en de arbeidsmarktperspectieven van de betreffende opleiding zoals geraamd door het ROA en besproken in hoofdstuk 3.

\subsection{De positie van arbeidsgehandicapten in Nederland}

\section{Arbeidsgehandicapten in Nederland}

De uitgaven aan ziekte en arbeidsongeschiktheid zijn met 3,8 procent van het bruto binnenlands product relatief hoog in Nederland. Het OESO-gemiddelde is 2,6 procent in 2009. ${ }^{172}$ Ook het aandeel personen met een arbeidsongeschiktheidsuitkering is met 8,1 procent van de (potentiële) beroepsbevolking hoog ten opzichte van het OESOgemiddelde van 5,7 procent. In tegenstelling tot de meeste OESO-landen is de instroom in arbeidsongeschiktheidsregelingen in Nederland de laatste jaren teruggelopen. De instroom daalde van ongeveer 100.000 personen per jaar in de periode 1998-2001 tot 40.000 in de periode 2010-2012. ${ }^{133}$ De verschillende beleidshervormingen ter vermindering van de instroom in arbeidsongeschiktheid - die plaatsvonden na 1998 - hebben onmiskenbaar geleid tot deze dalende instroom in arbeidsongeschiktheid. Het is echter niet precies bekend hoe groot de bijdrage van de specifieke beleidsmaatregelen geweest is. Er zijn echter wel enkele studies die aantonen dat de Wet Poortwachter en de introductie van de WIA hebben bijgedragen aan de daling van de instroom in arbeidsongeschiktheid. ${ }^{174}$ Deze, en andere beleidsmaatregelen, kunnen dus in ieder geval ten dele de dalende instroom in arbeidsongeschiktheidsregelingen verklaren. ${ }^{75}$ Daarmee is uitgesloten dat de dalende instroom puur en alleen het gevolg is van een gezondere (potentiële) beroepsbevolking.

Met de Participatiewet die op 1 januari 2015 in werking is getreden beoogt het kabinet een verhoging van de arbeidsdeelname van personen met een langdurige ziekte of handicap. Daartoe worden verschillende maatregelen genomen, zoals het verstrekken van loonkostensubsidies, een banenafspraak en het hanteren van een banenquotum. De doelgroep van de banenafspraak bestaat uit mensen met een (oud of nieuwe) Wajong-uitkering, mensen in de sociale werkvoorziening (of die daarvoor in de wachtlijst staan) en mensen met een WIW- of ID-baan. Het banenquotum heeft eveneens

171 Zie voor een vergelijkbare studie Sanders, de Vos en Besseling (2009), 'Re-integratie met perspectief, Een verkenning van de arbeidsmarktpositie, arbeidsmarktperspectieven en kansrijke beroepen voor re-integratie voor AO-uitkeringsgerechtigden' van TNO.

172 Euwals, Van Vuuren en Ter Weel (2014), Werken in goede gezondheid, CPB Policy Brief 2014/03.

173 Idem voetnoot 172.

174 Van Sonsbeek en Gradus (2013), Estimating the effects of recent disability reforms in the Netherlands, Oxford Economic Papers, 65: 832-855; Garica-Gomez, Gaudecker en Lindeboom (2011), Health, disability and work: patterns for the working age population, International Tax and Public Finance, 18: 146-165.

175 Koning (2009), Experience rating and the inflow into disability insurance, De Economist, 157: 315-335. 
betrekking op deze mensen, en daarnaast op alle anderen die onder de Participatiewet vallen en niet zelfstandig het wettelijk minimumloon kunnen verdienen. Dit hoofdstuk richt zich op een bredere groep arbeidsgehandicapten, uitgaande van de definitie van SZW, CBS en TNO (2011): "Arbeidsgehandicapten zijn personen die aangeven dat zij door een langdurige aandoening, ziekte of handicap worden belemmerd bij het uitvoeren of verkrijgen van werk." Deze definitie staat los van het al dan niet toegang krijgen tot sociale zekerheidsregelingen voor arbeidsgehandicapten en de Participatiewet. Op deze manier wordt een beeld verkregen van de groep mensen die aangeven beperkt te zijn in het verkrijgen of uitvoeren van werk, maar niet per definitie onder de geplande regeling vallen.

De cijfers die worden gebruikt zijn afkomstig van de EBB, waarin informatie is opgenomen over arbeidsbeperkingen in de periode 2002-2013, met uitzondering van de jaren 2007 en 2008. Vanwege wijzigingen in de vraagstelling van de EBB zijn er voor die jaren geen cijfers beschikbaar over arbeidsgehandicapten. De aandoening, ziekte of handicap die het werken (of vinden van werk) belemmert kan zowel fysiek als psychisch zijn, waarmee de groep arbeidsgehandicapten zeer divers is. In de Nationale Enquête Arbeidsomstandigheden (NEA) - die uitsluitend betrekking heeft op werknemers - is informatie opgenomen over het type arbeidshandicap. Daarom worden de cijfers van het CBS soms aangevuld met cijfers van de NEA. ${ }^{176}$ In dit hoofdstuk wordt, in tegenstelling tot andere hoofdstukken, gekeken naar de bevolking in de leeftijd van 15 tot 65 jaar met een baan van 12 per week of meer. ${ }^{177}$

In 2013 telde Nederland ruim 1,5 miljoen arbeidsgehandicapten in de leeftijd van 15 tot 65 jaar. ${ }^{178}$ Dit is 14,1 procent van alle mensen woonachtig in Nederland in dezelfde leeftijdscategorie. Het percentage arbeidsgehandicapten ligt onder vrouwen $(16,1 \%)$ hoger dan onder mannen (12,0\%). Limburg telt het hoogste percentage arbeidsgehandicapten $(18,5 \%)$, gevolgd door Groningen $(16,5 \%)$ en Drenthe $(16,1 \%)$. Utrecht telt relatief gezien de minste arbeidsgehandicapten (11,9\%). Er blijkt een positieve relatie te bestaan tussen leeftijd en het hebben van een arbeidshandicap. Terwijl onder 15 tot 20 jarigen 6,5\% arbeidsgehandicapt is, loopt dit percentage op tot $26,3 \%$ onder 60 tot 65 jarigen.

Arbeidsgehandicapten zijn gemiddeld genomen minder hoog opgeleid dan nietarbeidsgehandicapten (zie figuur 5.1). Terwijl ongeveer een kwart van de niet-arbeidsgehandicapten alleen lager onderwijs heeft afgerond, geldt dat bijna vier op de tien arbeidsgehandicapten alleen lager onderwijs heeft afgerond. Het percentage dat middelbaar onderwijs heeft afgerond maar geen diploma in het hoger onderwijs behaalde is even groot in beide groepen (afgerond 42\%). Daarmee ligt het percentage

176 In de NEA wordt uitgegaan van dezelfde definitie van arbeidsgehandicapten als in de EBB hoewel de exacte vraagformuleringen verschillen.

177 Reden hiervoor is dat het gros van het onderzoek uitgevoerd is voor de overgang naar de internationale definitie van arbeid.

$178 \mathrm{Er}$ is voorzichtigheid geboden in het vergelijken van absolute cijfers over de omvang van de (verschillende groepen) arbeidsgehandicapten in verband met een methodebreuk in 2010 en een kleine wijziging in de vraagstelling in 2013 . 
dat hoger onderwijs heeft afgerond voor arbeidsgehandicapten automatisch beduidend lager (17,3\%) dan voor niet-arbeidsgehandicapten (31,3\%).

FIGUUR 5.1 Opleidingsniveau van arbeidsgehandicapten en niet-arbeidsgehandicapten (bevol king 15-65 jaar)

Arbeidsgehandicapt

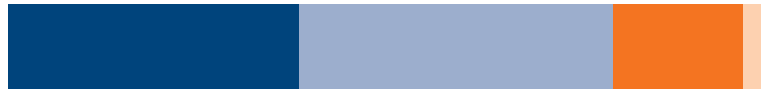

Niet arbeidsgehandicapt

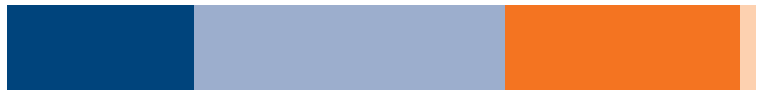

0

$10 \quad 20$

30

40

50

60

70

80

90

$100 \%$

lager onderwijs middelbaar onderwijs

hoger onderwijs

onderwijs onbekend

Bron: EBB (2013)

\section{Arbeidsmarktpositie van arbeidsgehandicapten}

In figuur 5.2 is voor arbeidsgehandicapten (links) en niet-arbeidsgehandicapten (rechts) die tot de bevolking van 15 tot 65 jaar behoren weergegeven hoe zij in 2013 verdeeld waren over de verschillende subgroepen: werkzame beroepsbevolking, werkloze beroepsbevolking en niet-beroepsbevolking. Mensen worden tot de werkende beroepsbevolking gerekend wanneer zij een substantieel aantal uren per week betaald werken. ${ }^{179}$ Werkloos zijn zij die niet of geen substantieel aantal uren per week werken, maar dat wel zouden willen. De overige bevolking in de leeftijd 15 tot 65 - zij die niet werken en dit ook niet willen en/of kunnen - wordt aangeduid als niet-beroepsbevolking of inactief. De ruime meerderheid van de arbeidsgehandicapten behoort tot deze laatstgenoemde groep. Het aandeel behorend tot de niet-beroepsbevolking is onder arbeidsgehandicapten met $60,5 \%$ bijna drie keer zo groot als onder de potentiële bevolking zonder arbeidshandicap (22,6\%). Zoals eerder vastgesteld zijn niet-arbeidsgehandicapten met een aandeel van $71,5 \%$ ruim twee keer vaker werkzaam dan arbeidsgehandicapten. Van deze laatste groep had een derde een baan in $2013 .{ }^{180} \mathrm{Het}$ aandeel werklozen van de totale bevolking van 15 tot 65 jaar ligt voor beide groepen afgerond op $6 \%$.

179 In de operationalisering van een substantieel aantal uren werd in 2013 uitgegaan van ten minste twaalf uur per week. Vanaf anderhalve dag per week geeft de meerderheid van de mensen namelijk aan dat betaald werk de belangrijkste bezigheid is (zie: Bierings, Henricus B., J. C. M. Imbens, and C. A. Van Bochove, De definitie van de beroepsbevolking, Supplement Sociaal-Economische Maandstatistiek 2 (1991): 4-21).

180 Omdat het hier data uit 2013 betreft, gaat het hierbij nog om de oude definitie van werkenden, namelijk een baan van tenminste 12 uur per week voor een duur van tenminste drie maanden. 
FIGUUR 5.2 Bevolking van 15 tot 65 jaar naar arbeidspositie

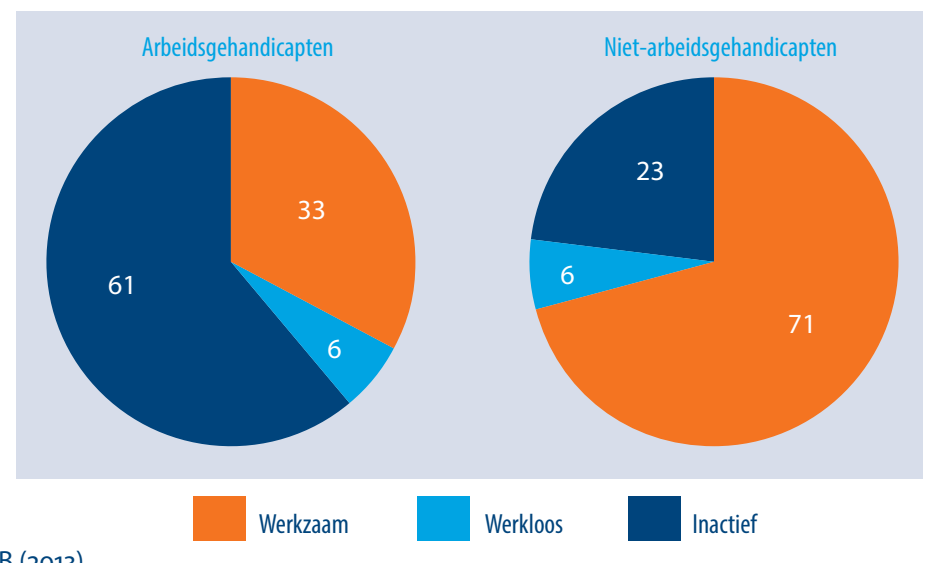

Bron: EBB (2013)

In figuur 5.3 is voor elke groep: 'werkzaam,',werkloos' en 'inactief' de verdeling naar opleidingsniveau gegeven. Voor elke groep is een staaf voor zowel de arbeidsgehandicapten als de niet-arbeidsgehandicapten in de figuur opgenomen. Aan de hand figuur 5.1 werd reeds geconcludeerd dat arbeidsgehandicapten over het algemeen lager zijn opgeleid dan niet-arbeidsgehandicapten. 
In periode van economische neergang neemt de werkloosheid onder arbeidsgehandicapten sterker toe dan onder niet-arbeidsgehandicapten. 0ok in de huidige economische crisis liepen deze werkloosheidspercentages verder uiteen, zoals te zien is in onderstaande figuur.

\section{FIGUUR B5.1 Werkloosheidspercentages onder arbeidsgehandicapten en niet-arbeidsgehandicapten}

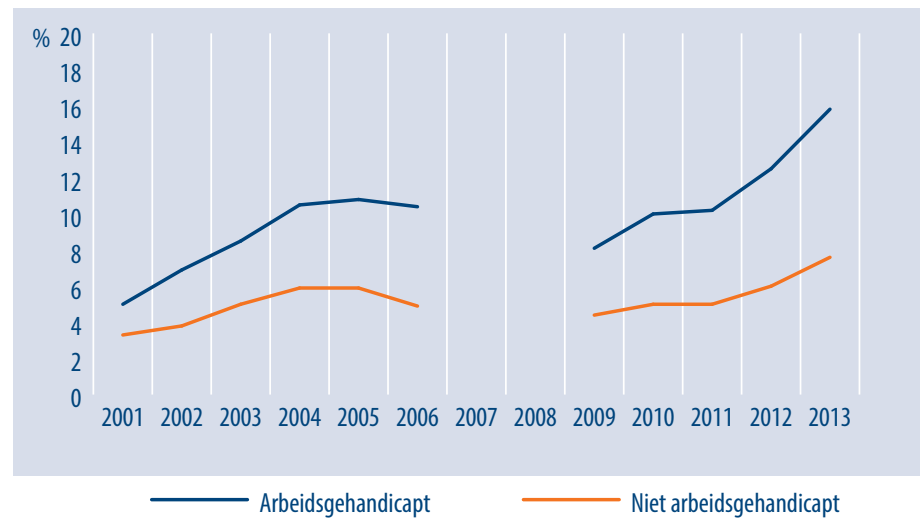

Bron: EBB

Noot: Vanwege wijzigingen in de vraagstelling van de EBB zijn voor de jaren 2007 en 2008 geen cijfers over arbeidshandicap.

Uit een studie naar de positie van arbeidsgehandicapten in crisistijd blijkt dat deze verschillen niet zijn toe te schrijven aan de concentratie van arbeidsgehandicapten in bedrijfstakken die sterk krompen als gevolg van de crisis. Daarentegen is de netto participatie van arbeidsgehandicapten binnen alle bedrijfstakken sterker gedaald dan de netto participatie van mensen zonder arbeidshandicap. Dit kan duiden op een grotere crisisgevoeligheid van het werk dat arbeidsgehandicapten binnen de verschillende bedrijfstakken verrichten. Arbeidsgehandicapten hebben vaker een laag opleidingsniveau, werken vaker in elementaire beroepen en ervaren minder autonomie in hun werk dan niet-arbeidsgehandicapten.

Over het algemeen geldt dat personen met een baan - in vergelijking tot de gehele bevolking van 15 tot 65 jaar - minder vaak laagopgeleid zijn. Hoewel dit ook geldt voor arbeidsgehandicapten, is het gemiddelde opleidingsniveau van werkende arbeidsgehandicapten lager dan dat van werkenden zonder arbeidshandicap en zelfs lager dan het gemiddelde opleidingsniveau van de totale bevolking zonder arbeidsbeperking. ${ }^{182}$ De groep werkende arbeidsgehandicapten is voor wat betreft opleidingsachtergrond

181 Deze tekstbox is gebaseerd op De Hoon, M., A. Kunn-Nelen, H-J. Dirven en H. Lautenbach (2015), Arbeidsgehandicapten in crisistijd. ESB, 100(4704): 106-109.

182 Deze negatieve correlatie tussen het hebben van een arbeidshandicap en het opleidingsniveau wordt sterker wanneer enkel respondenten in de leeftijdscategorie 25-35 worden meegenomen (van -0.0758 naar -0.0896) (o.b.v. NEA 2012). Hierop kan worden geconcludeerd dat verschillen in opleidingsachtergrond tussen arbeidsgehandicapte en niet-arbeidsgehandicapten niet kunnen worden verklaard door verschillen in leeftijdssamenstelling. 
vergelijkbaar met de groep werkloze niet-arbeidsgehandicapten. De niet-beroepsbevolking ofwel 'inactieven' zijn gemiddeld genomen het laagst opgeleid. In tegenstelling tot de totale bevolking verschillen arbeidsgehandicapten hier niet van niet-arbeidsgehandicapten betreffende de opleidingsachtergrond. Voor beide groepen geldt dat iets minder dan de helft van de inactieven enkel basisonderwijs genoten heeft. lets meer dan één op de tien inactieven heeft een diploma in het hoger onderwijs behaald.

FIGUUR 5.3 Verdeling van arbeidsgehandicapten naar opleidingsniveau en werkstatus

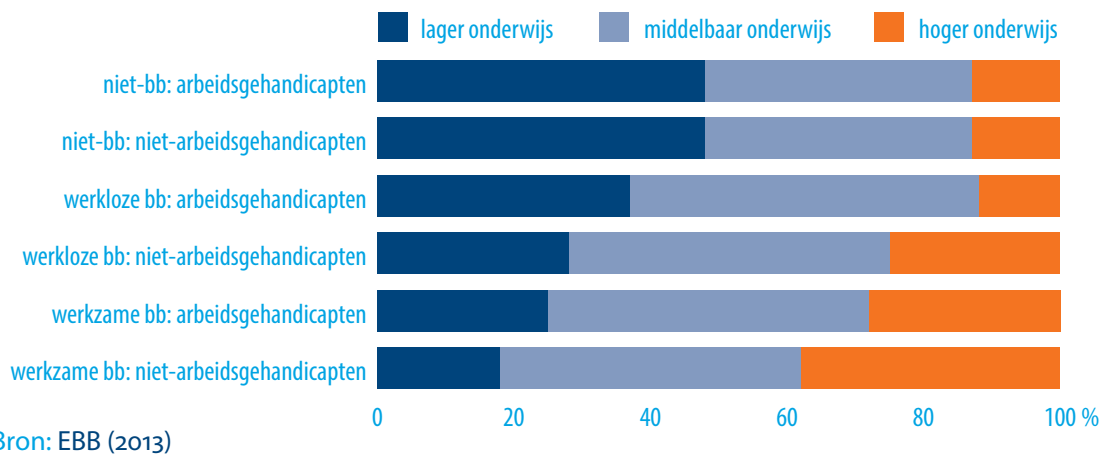

Of arbeidsgehandicapten al dan niet aan het werk kunnen, hangt onder andere af van de aard van hun aandoening, ziekte of handicap. Hoewel hier in de EBB geen informatie over beschikbaar is, biedt de NEA wel de mogelijkheid om in te gaan op het type arbeidshandicap. Omdat alle respondenten in de NEA werkzaam zijn, is het niet mogelijk om te kijken in hoeverre het type handicap de kans op werk beïnvloedt. Wel biedt het de mogelijkheid om inzicht te krijgen in het type handicap of aandoening van de werkende arbeidsgehandicapten. Meer dan één op de vier werkende arbeidsgehandicapten geeft aan meer dan één ziekte of aandoening te hebben. Om inzicht te krijgen in de meest voorkomende ziektes of aandoeningen wordt daarom in figuur 5.4 weergegeven hoe vaak de NEA-respondenten elk van de ziektes of aandoeningen aangekruist hebben die voorkomen op de lijst met mogelijke ziektes en aandoeningen in de NEA. ${ }^{183}$

Ruim één op de drie werkende arbeidsgehandicapten geeft aan problemen met rug en nek (ook artritis, reuma, RSI) te hebben. Hiermee is dit de meest voorkomende chronische ziekte of aandoening onder arbeidsgehandicapten met een baan. Problemen met armen of handen wordt door ruim één op de vijf werkende arbeidsgehandicapten genoemd als langdurige aandoening en 19,4\%heeft chronische problemen met benen of voeten en een vergelijkbaar percentage lijdt aan migraine of ernstige hoofdpijn.

183 Een deel van de respondenten $(15,6 \%)$ heeft aangegeven een andere ziekte of aandoening te hebben dan welke in figuur 5.4 zijn gegeven. 
FIGUUR 5.4 Type arbeidshandicap onder werkende arbeidsgehandicapten

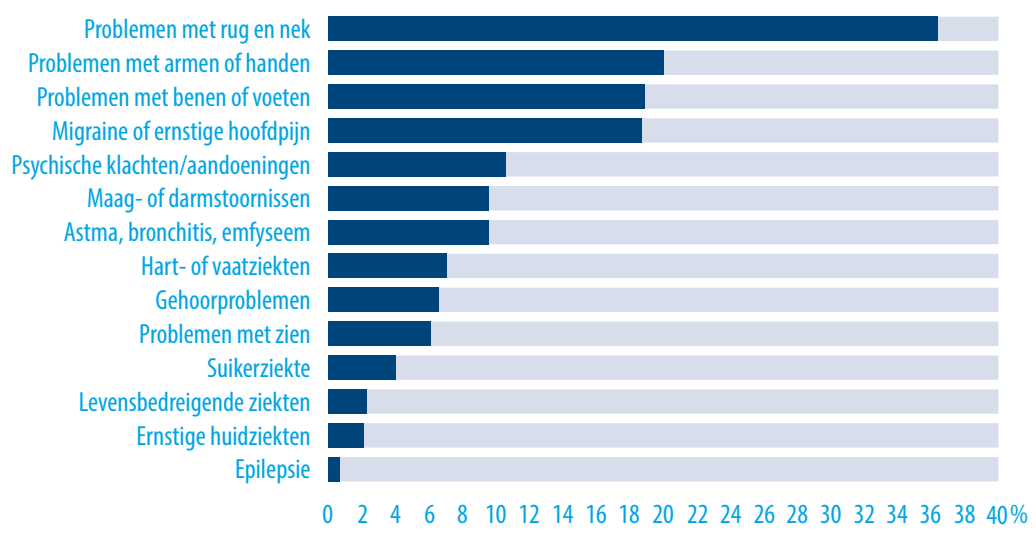

Bron: NEA (2012)

Voorts heeft iets meer dan één op de tien arbeidsgehandicapten met een baan psychische klachten. Dit is een relatief laag aandeel gezien het feit dat voor mensen met een arbeidsongeschiktheidsuitkering een psychische aandoening de meest gestelde diagnose is (35-41\%). ${ }^{184}$ Een psychische aandoening blijkt daarnaast voor werknemers tot 45 jaar de meest voorkomende oorzaak van langdurig verzuim. ${ }^{185}$ De vaststelling van een relatief laag aandeel arbeidsgehandicapten met psychische klachten op basis van NEA-gegevens kan verschillende oorzaken hebben. Ten eerste worden de werkenden met de uitkeringsgerechtigden vergeleken. Hoewel deze groepen voor een deel overlappen (uitkeringsgerechtigden met een baan), is dit een wezenlijk verschil. Het is denkbaar dat arbeidsgehandicapten met psychische klachten in relatief veel gevallen gediagnosticeerd worden, een arbeidsongeschiktheidsuitkering ontvangen en daarom niet (kunnen) werken. De bevinding van het UWV dat relatief meer mensen met psychische aandoeningen een WIA-uitkering aanvragen en minder vaak werken dan andere groepen arbeidsbeperkten strookt hiermee. ${ }^{186}$ Een tweede mogelijkheid is dat deze arbeidsgehandicapten door hun psychische klachten niet aan het werk komen en daardoor minder vaak werkzaam zijn (en mogelijk vaker werkloos). Zo blijkt uit onderzoek onder werkgevers dat werknemers met psychische klachten het minst gewild zijn. ${ }^{187}$ Voorts is het denkbaar dat psychische aandoeningen in een vragenlijst ondergerapporteerd zijn wegens schaamte en/of sociale wenselijkheid.

Het aandeel arbeidsgehandicapten dat last heeft van maag-/ darmstoornissen of astma, bronchitis, of emfyseem bedraagt één op de tien. Voor de overige beperkingen en/of

184 UWV Monitor Arbeidsparticipatie 2013 (WGA volledig 41\%, WGA gedeeltelijk 53\%, WIA 35-min 37\%).

185 ArboNed. (z.d.) Kort Frequent Verzuim. Verkregen via: http://www.arboned.nl/verzuimbegeleiding/kortfrequent-verzuim/

186 UWV Monitor 2013. UWV Monitor Arbeidsparticipatie 2014. Verkregen via https://www.rijksoverheid.nl/documenten/rapporten/2014/02/03/uwv-monitor-arbeidsparticipatie-2013 op 9 november 2015.

187 Houtman, I., Koppes, L. \& Dekker, F. (2013), Verklaring van de stijging in WIA-instroom: Een werknemers- en werkgeversperspectief, Leiden: TNO, met subsidie van UWV. 
langdurige ziekten in de figuur geldt dat dit door minder dan 10 procent van de respondenten werd genoemd. Hiervan zijn hart- of vaatziekten $(7,6 \%)$, gehoorproblemen $(7,1 \%)$ en problemen met zien $(6,0 \%)$ het meest voorkomend.

\section{Waar werken arbeidsgehandicapten?}

In figuur 5.5 is het percentage arbeidsgehandicapten per sector weergegeven voor 2013. De horizontale lijn geeft het percentage arbeidsgehandicapten gemiddeld over alle sectoren weer. De staven geven het percentage per sector aan, plus het gemiddelde van alle publieke sectoren enerzijds en de private sectoren anderzijds. ${ }^{188}$ De ruiten boven de staven worden later toegelicht. Gemiddeld genomen is 7,1 procent van de werkenden arbeidsgehandicapt. Het percentage arbeidsgehandicapten blijkt sterk te verschillen tussen sectoren. In de overige industrie werken procentueel gezien de meeste arbeidsgehandicapten; bijna één op de vijf werkenden in deze sector is arbeidsgehandicapt. Het verdient vermelding dat de sociale werkvoorzieningen deel uitmaken van deze sector. Voor de overige sectoren ligt het aandeel arbeidsgehandicapten aanzienlijk lager, in alle gevallen lager dan 9\%. De zeven sectoren met een (afgerond) bovengemiddeld aandeel zijn welzijn (8,8\%), landbouw, bosbouw en visserij en voedings- en genotmiddelenindustrie $(8,2 \%)$, verhuur en overige zakelijke dienstverlening $(8,1 \%)$, onderwijs $(7,7 \%)$ en horeca $(7,6 \%)$. De sectoren met de laagste percentages arbeidsgehandicapten zijn energie, metaalindustrie, groothandel, informatie en communicatie, en financiële dienstverlening en onroerend goed. In deze sectoren is minder dan $5 \%$ van de werkenden arbeidsgehandicapt.

De vraag waarom het aandeel arbeidsgehandicapten aanzienlijk verschilt per sector kan op basis van de beschikbare databronnen niet exact worden beantwoord. Het is in ieder geval belangrijk een onderscheid te maken tussen mensen die al vóór intrede in een bepaalde sector een (aangeboren) arbeidsbeperking hadden en mensen die gedurende hun beroepsloopbaan binnen een bepaalde sector arbeidsgehandicapt raken. In het laatste geval wordt vaak nog onderscheid gemaakt tussen 'risque professionel' en 'risque sociale', waarbij 'risque professionel' inhoudt dat de opgelopen ziekte of beperking veroorzaakt is op de werkvloer. Zo is het denkbaar dat in sectoren waarin hoofdzakelijk (zware) fysieke arbeid wordt verricht (industrie of landbouw) relatief veel arbeidsgehandicapten werkzaam zijn, niet zozeer doordat werkgevers in deze sector eerder arbeidsgehandicapten aannemen, maar doordat zij vaker te maken hebben met werknemers die arbeidsbeperkt raken als gevolg van het werk dat zij verrichten. In de NEA is gevraagd waardoor de ziekte of aandoening van arbeidsgehandicapten is veroorzaakt. ${ }^{189}$ Het is echter niet vast te stellen of de langdurige aandoeningen als gevolg van werk zijn veroorzaakt binnen de sector waar de respondent op het meetmoment werkzaam is, of in een vorige baan in een andere sector. Voor wat betreft de arbeidsgehandi-

188 Voor een aantal sectoren is het percentage arbeidsgehandicapten onbekend door het te kleine aantal werkenden in de sector.

189 Antwoordcategorieën: 'het werk', 'een ongeval op het werk', 'een verkeersongeval', 'een ongeval thuis, in de vrije tijd of tijdens het sporten','aangeboren', 'anders'. 
capten met een aangeboren ziekte of aandoening kan in ieder geval wel worden gesteld dat zij deze beperking al hadden vóór hun arbeidsmarktintrede in een bepaalde sector.

FIGUUR 5.5 Arbeidsgehandicapten als percentage van het totaal aantal werkenden per sector in 2013

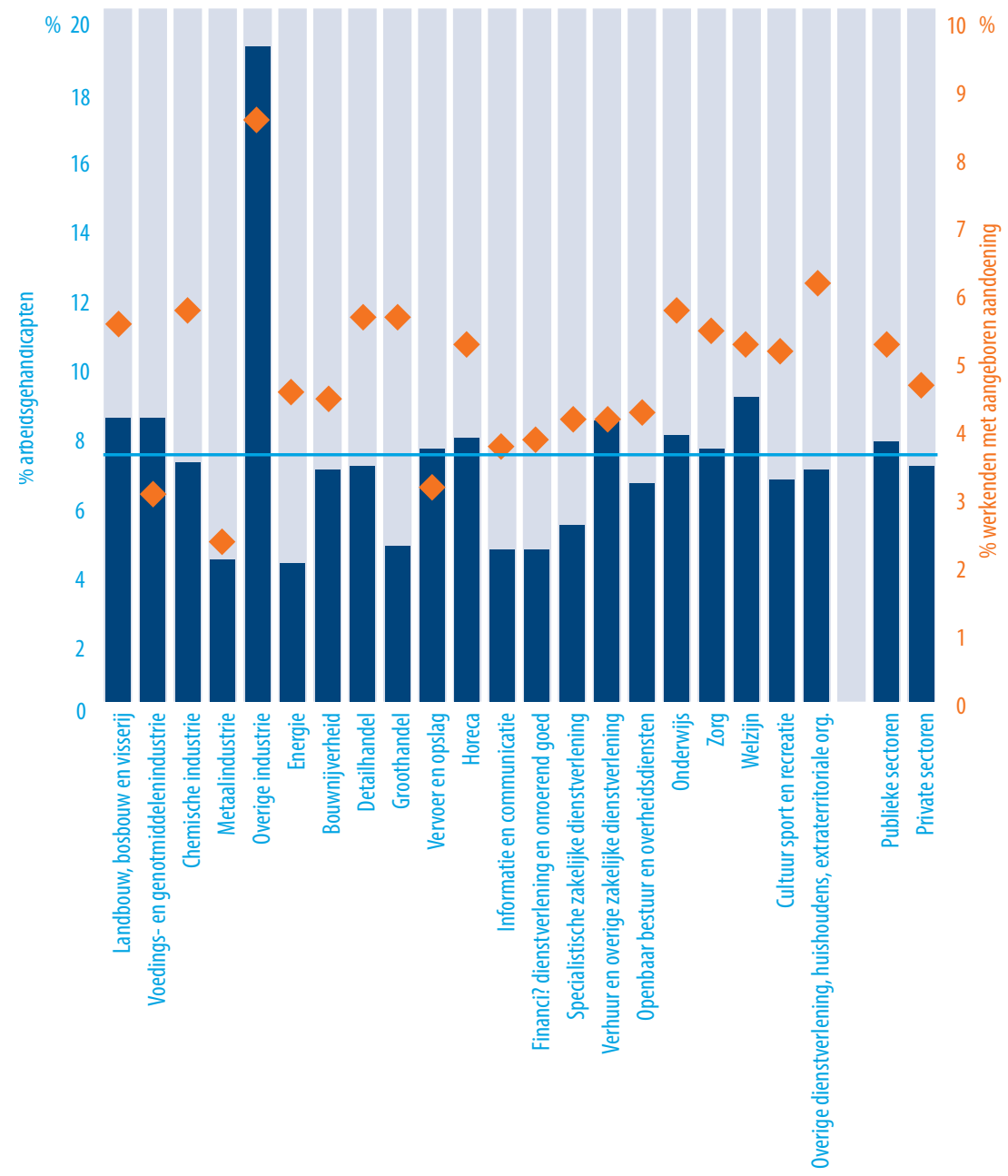

Bron: EBB (2013) \& NEA (2011)

In figuur 5.5 is daarom voor iedere sector het aandeel werkzame personen met een aangeboren ziekte of beperking gegeven. Het is voor de lezer belangrijk zich te realiseren dat hierbij gebruikt gemaakt is van NEA-data, waarbij het relatieve aantal arbeidsgehandicapten groter is dan in de EBB, zeer waarschijnlijk (hoofdzakelijk) een gevolg 
van de manier van bevragen. ${ }^{190}$ Bovendien betreffen de NEA-gegevens over de arbeidshandicap 2011, terwijl de gepresenteerde EBB-gegevens uit 2013 afkomstig zijn. De rangschikking van sectoren op basis van het aandeel arbeidsgehandicapten verschilt op basis van de NEA echter weinig van deze op basis van de EBB.

Het aandeel arbeidsgehandicapten ligt in de publieke sector hoger dan in de private sector. Dit geldt eveneens voor het aandeel werkende met een aangeboren aandoening, dat gemiddeld genomen $5,4 \%$ bedraagt voor de publieke en $4,8 \%$ voor de private sector. Hoewel er een positieve relatie bestaat tussen het aandeel arbeidsgehandicapten en het aandeel werkenden met een aangeboren aandoening in een sector, zijn de sectoren met een hoog percentage arbeidsgehandicapten niet per definitie ook de sectoren die relatief veel werkenden met een aangeboren handicap aannemen. De sector voedingsen genotmiddelenindustrie enerzijds en de sectoren energie en groothandel anderzijds illustreren dit. In de sector voedings- en genotmiddelenindustrie is het aandeel arbeidsgehandicapten relatief hoog. Het aandeel arbeidsgehandicapten met een aangeboren aandoening $(3,2 \%)$ ligt voor deze sector echter lager dan voor iedere andere sector. Het aandeel arbeidsgehandicapten is binnen de sectoren groothandel en overige dienstverlening lager dan gemiddeld. Het aandeel werknemers met een aangeboren aandoening is echter relatief groot (respectievelijk $5,8 \%$ en $6,3 \%$ ) in deze sectoren. Voorts is binnen de sector overige industrie zowel het aandeel arbeidsgehandicapten als het aandeel werkenden met een aangeboren handicap zeer hoog. Zoals eerder vermeld is dit toe te schrijven aan het feit dat de sociale werkvoorzieningen tot deze sector worden gerekend.

Arbeidsgehandicapten zijn eveneens onevenredig verdeeld over beroepsgroepen. In figuur 5.6 is het percentage arbeidsgehandicapten in 2013 per beroepsklasse weergegeven. Het percentage arbeidsgehandicapten is het hoogste in de agrarische beroepen: $11 \%$ van de werkenden in deze beroepsgroep is arbeidsgehandicapt. Dit is in overeenstemming met de bevinding in figuur 5.5 dat er relatief veel arbeidsgehandicapten werkzaam zijn in de sector landbouw, bosbouw en visserij. Ook zijn de arbeidsgehandicapten oververtegenwoordigd in de dienstverlenende beroepen $(8,8 \%)$, de creatieve en taalkundige beroepen $(8,6 \%)$, de transport- en logistiekberoepen $(8,1 \%)$ en de pedagogische beroepen $(8,0 \%)$. Onder de managers komen arbeidsgehandicapten relatief gezien juist het minst vaak voor $(5,0 \%)$. Deze verdeling van arbeidsgehandicapten over de beroepsgroepen is in lijn met de verdeling naar opleidingsniveau (zie figuur 5.1).

190 In de EBB wordt een tweetrapsvraag voorgelegd aan de respondenten, waarbij hen eerst wordt gevraagd of zij een langdurige ziekte, aandoening of handicap hebben. Indien het antwoord 'ja' is, dan wordt gevraagd of zij daardoor worden belemmerd bij het uitvoeren of vinden van werk. In de NEA wordt direct gevraagd op een lijst met langdurige ziekten, aandoeningen of handicaps aan te kruisen welke daarvan op hen van toepassing is. Vervolgens wordt gevraagd of zij daardoor worden belemmerd bij het uitvoeren van het werk. 
FIGUUR 5.6 Percentage arbeidsgehandicapten per beroepsklasse in 2013

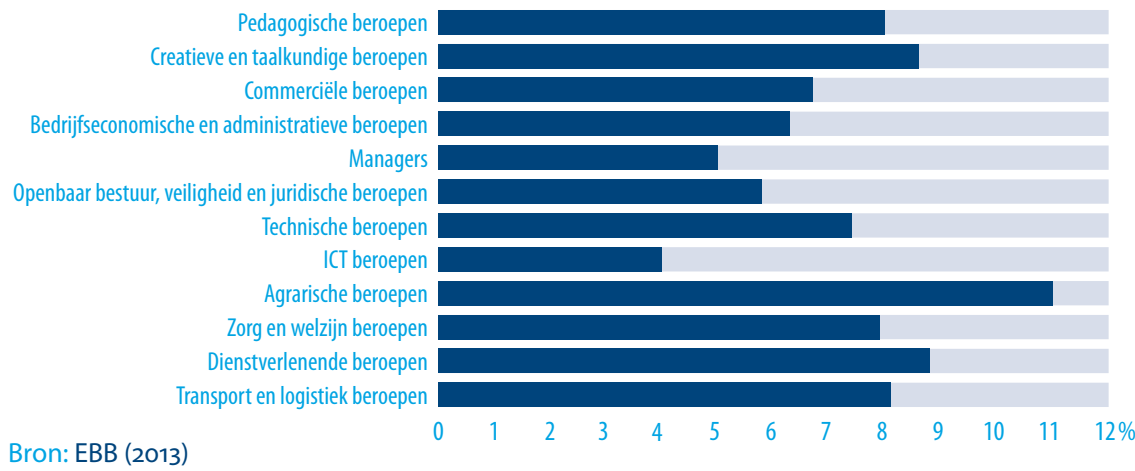

In figuur 5.7 is een opsplitsing van het percentage arbeidsgehandicapten per opleidingscategorie weergegeven. Het hoogste percentage arbeidsgehandicapten wordt gevonden voor gediplomeerden van opleidingen binnen de opleidingscategorie mbo $2 / 3$ groen: $11,5 \%$ van alle werkenden met deze opleidingsachtergrond heeft een arbeidshandicap. Ook zijn er relatief veel arbeidsgehandicapten onder personen met een opleiding uit de categorie mbo $2 / 3$ zorg en welzijn $(11,4 \%)$ en met alleen basisonderwijs of een vmbo opleiding (9,9\%). Het percentage arbeidsgehandicapten in vergelijkbare opleidingscategorieën op mbo niveau 4 ligt wat lager. Arbeidsgehandicapten zijn duidelijk minder vertegenwoordigd in de hbo-en wo- opleidingen dan in de mbo-opleidingen.

FIGUUR 5.7 Percentage arbeidsgehandicapten per opleidingscategorie in 2013

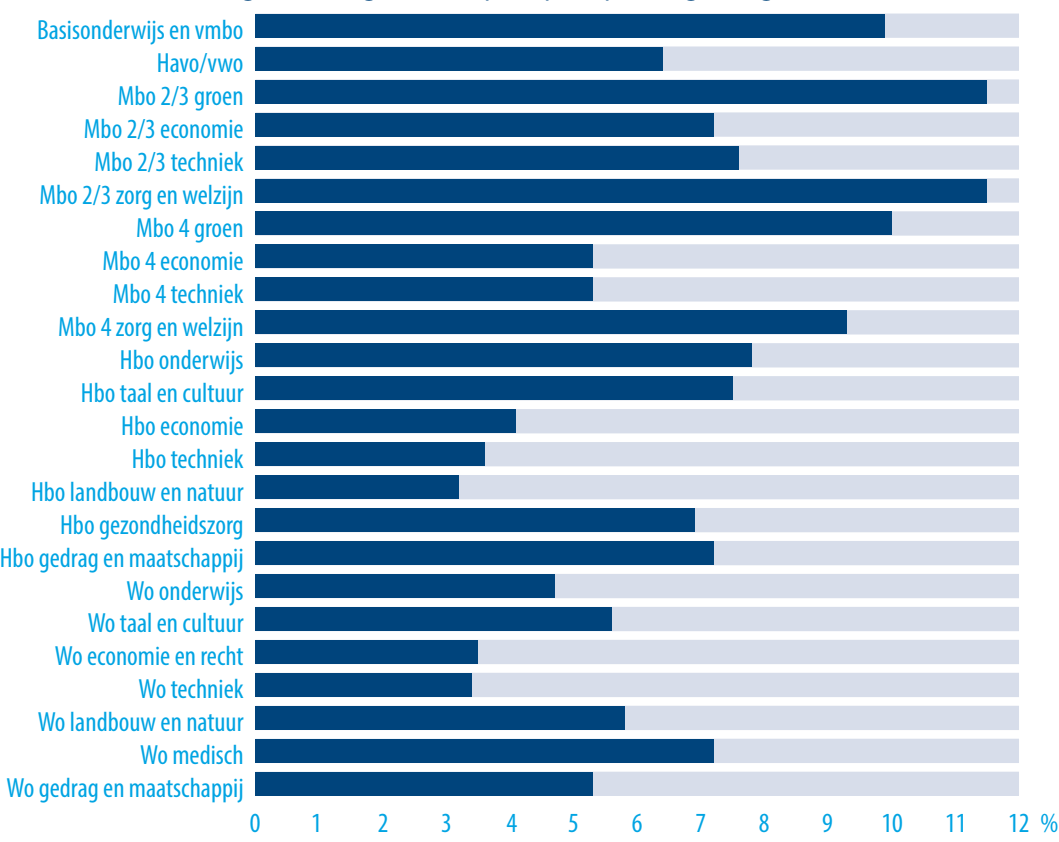

Bron: EBB (2013) 
Van alle hbo opleidingscategorieën is het percentage arbeidsgehandicapten het hoogste voor hbo onderwijs (7,8\%), gevolgd door hbo taal en cultuur $(7,5 \%)$ en hbo gedrag en maatschappij (7,2\%). Het percentage arbeidsgehandicapten in de opleidingscategorie hbo landbouw en natuur is juist relatief laag (3,2\%). Dit is opvallend omdat de mbo $2 / 3$ en mbo 4 groen opleidingen juist relatief veel arbeidsgehandicapten tellen. Het hoge percentage arbeidsgehandicapten in de agrarische beroepen vertegenwoordigt dus vooral werkende arbeidsgehandicapten met een mbo opleiding. Arbeidsgehandicapten zijn binnen het wo het meest vertegenwoordigd in de wo medische opleidingen: 7,2\% van alle werkenden met deze opleidingsachtergrond is arbeidsgehandicapt. Binnen het wo telt de opleidingscategorie techniek, relatief gezien, de minste arbeidsgehandicapten.

\section{Baankenmerken van arbeidsgehandicapten}

De EBB biedt inzicht in de standaard baankenmerken van werkend Nederland. Het gaat om informatie over de werkomvang, wensen met betrekking tot meer of minder willen werken, flexibel contract en zelfstandigheid. In tabel 5.1 wordt deze informatie voor arbeidsgehandicapten en niet-arbeidsgehandicapten weergegeven.

TABEL 5.1 Baankenmerken arbeidsgehandicapten

\begin{tabular}{|l|r|r|}
\hline Gemiddelde arbeidsduur (uren per week) & Arbeidsgehandicapten & Niet-arbeidsgehandicapten \\
\hline $12-20$ uur per week (\%) & 31,2 & 34,3 \\
\hline $20-35$ uur per week (\%) & 13,9 & 9,2 \\
\hline$>35$ uur per week (\%) & 43,5 & 31,8 \\
\hline Wil meer uren werken (\%) & 42,7 & 59,0 \\
\hline Wil gelijk aantal uren werken (\%) & 9,6 & 10,4 \\
\hline Wil minderuren werken of stoppen (\%) & 80,1 & 83,1 \\
\hline Werknemers met vast dienstverband (\%) & 10,3 & 6,5 \\
\hline Werknemers met flexibele arbeidsrelatie (\%) & 71,3 & 68,1 \\
\hline Zelfstandigen (\%) & 12,0 & 16,9 \\
\hline
\end{tabular}

Bron: EBB (2013)

De gemiddelde werkweek van arbeidsgehandicapten in de werkzame beroepsbevolking ligt met 31,2 uur per week iets lager dan onder niet-arbeidsgehandicapten (34,3 uur). Slechts $13,9 \%$ van de arbeidsgehandicapten werkt tussen de 12 en 20 uur per week. 43,5\% werkt tussen de 20 en 35 uur per week en de overige 42,7\% werkt meer dan 35 uur. Acht op de tien arbeidsgehandicapten zou de omvang van hun werkweek niet willen aanpassen. Van de overige $20 \%$ wil de helft meer uren werken terwijl de andere helft juist liever minder uren zou willen werken (of zelfs wil stoppen met werken). Met name in de nijverheid en industrie zijn de arbeidsgehandicapten (net als de niet-arbeidsgehandicapten) tevreden met de omvang van hun werkweek, $88 \%$ zou niet meer of minder willen werken. ${ }^{191}$ De arbeidsgehandicapten in de commerciële dienstverlening

191 Baankenmerken per sector zijn niet in een tabel weergegeven. 
zouden juist vaker dan gemiddeld (en vaker dan de niet-arbeidsgehandicapten) meer uren willen werken $(13,0 \%)$. Dit is ook terug te zien in de wens om meer uren te willen werken onder dienstverlenend personeel en verkopers. Meer dan 18\% van hen zou graag meer uren willen werken.

Het percentage arbeidsgehandicapte werknemers met een flexibel contract is in 2013 met $12 \%$ lager dan onder de niet-arbeidsgehandicapten (16,9\%). Het percentage zelfstandigen is met $16,7 \%$ juist iets hoger dan onder de niet-arbeidsgehandicapten (15,1\%). Uit de NEA blijkt bovendien dat werknemers met een langdurige ziekte, beperking of handicap niet hoofdzakelijk werkzaam zijn in grote bedrijven. ${ }^{192}$ Dit is tegen de verwachting dat grote bedrijven meer (financiële) mogelijkheden hebben om banen aan te bieden aan arbeidsgehandicapten. De mate van bereidheid om extra maatregelen te nemen om arbeidsgehandicapten aan te kunnen nemen blijkt wel afhankelijk te zijn van de bedrijfsgrootte, zo blijkt uit een enquête onder werkgevers in 2013 naar vacatures en wervingsactiviteiten van publieke en private bedrijven. ${ }^{193}$

De NEA biedt ook de mogelijkheid om in te gaan op het type werkzaamheden dat werkenden uitvoeren. ${ }^{194}$ Gecorrigeerd voor onder andere de beroepsgroep en sector waarin men werkzaam is, blijken arbeidsgehandicapten het werk dat zij verrichten anders te typeren dan werkenden zonder arbeidshandicap. Arbeidsgehandicapten ervaren minder autonomie dan niet-arbeidsgehandicapten. Ook ervaren zij minder variatie en innovatie in hun werk.

Het type arbeidshandicap blijkt ook van belang voor de mate waarin arbeidsgehandicapten al dan niet andere werkzaamheden hebben dan niet-arbeidsgehandicapten. ${ }^{195}$ Voor werknemers die beperkingen hebben door zien of horen, worden geen significante andere werkzaamheden gevonden dan voor niet-arbeidsgehandicapten. Dit geldt ook voor arbeidsgehandicapten die een levensbedreigende ziekte hebben (met uitzondering van de mate van gevarieerd werk). Voor werkenden die door astma/suikerziekte een arbeidshandicap hebben, blijkt de mate van gevarieerd en innovatief werk gelijk te zijn als voor werkenden zonder arbeidshandicap. Wel ervaren zij minder autonomie in hun werk. Bovendien blijkt de mate van gevarieerd werk voor arbeidsgehandicapten die beperkt zijn door psychische problemen gemiddeld genomen gelijk te zijn aan die van niet-arbeidsgehandicapten.

\footnotetext{
192 Informatie over bedrijfsgrootte is beschikbaar in de NEA voor de jaren 2007 tot en met 2012.

193 UWV Kennisverslag 2014/2 H2 Bereidheid om arbeidsgehandicapten in dienst te nemen.

194 In Bijlage E zijn de stellingen opgenomen die deze werkomstandigheden meten.

195 Getest door regressie analyses vergelijkbaar aan die gerapporteerd in tabel 5.3 maar dan met het type arbeidshandicap in plaats van de variabele arbeidshandicap ja/nee.
} 


\subsection{Subjectieve arbeidsmarktuitkomsten van arbeidsgehandicapten}

Zoals in de introductie aangegeven is, zijn er verschillende theorieën die voorspellen waarom arbeidsgehandicapten minder kans hebben op een baan. Ook als arbeidsgehandicapten wel aan het werk zijn is het echter de vraag of zij een gelijke arbeidsmarktpositie hebben als niet-arbeidsgehandicapten. Onderzoek laat voor de Verenigde Staten zien dat arbeidsgehandicapten over het algemeen een lager loon verdienen dan niet-arbeidsgehandicapten. ${ }^{196}$ Dat onderzoek laat zien dat dit het gevolg is van concentratie van arbeidsgehandicapten in lagere beroepen (met lage lonen) waar lage eisen gesteld worden aan opleidingsachtergrond en ervaring. Voor het Verenigd Koninkrijk wordt eveneens gevonden dat werkenden met een arbeidsbeperkende handicap een lager loon verdienen. ${ }^{197}$ Bovendien laat hetzelfde onderzoek zien dat arbeidsgehandicapten een grotere kans hebben op onderbenutting en dat de negatieve looneffecten van onderbenutting nog groter zijn voor arbeidsgehandicapten dan voor niet-arbeidsgehandicapten.

Naast discriminatie en een lagere productiviteit speelt ook de over het algemeen beperkte mate van mobiliteit een rol bij het verklaren van de positieve relatie tussen het hebben van een arbeidshandicap en onderbenutting. Middels de NEA is informatie verkregen over de tijd die werknemers per dag gemiddeld besteden aan woon-werkverkeer wat het mogelijk maakt om een indicatie te krijgen van de rol die mobiliteit speelt in de kans op (subjectieve) onderbenutting (voor arbeidsgehandicapten). Bovendien kunnen fysieke en mentale eisen van het werk, de werktijden en de toegankelijkheid de kans op een goede match tussen de opleidingsachtergrond en een baan voor arbeidsgehandicapten beperken. ${ }^{198}$

De NEA biedt de mogelijkheid om naast onderbenutting in te gaan op andere subjectieve arbeidsmarktuitkomsten die iets zeggen over de positie van arbeidsgehandicapten op de arbeidsmarkt. Zo wordt er gekeken of er een relatie is tussen het hebben van een arbeidshandicap en de mate waarin men de kans op baanverlies inschat. In tabel 5.2 wordt een overzicht gegeven van de enquêtevragen die gebruikt zijn om de subjectieve arbeidsmarktuitkomsten te definiëren.

196 Maroto and Pettinicchio (2014), Disability, structural inequality and work: The influence of occupational segregation on earnings for people with different disabilities, Research in Social Stratification and Mobility, 38: 76-92

197 Jones en Sloane (2010), Disability and skill mismatch, The Economic Record, 86: 101-114.

198 Zie voetnoot 197 . 
TABEL 5.2 Enquêtevragen en beschrijvende statistieken subjectieve arbeidsuitkomsten

\begin{tabular}{|c|c|c|c|}
\hline \multirow[t]{2}{*}{ Variabele } & \multirow[t]{2}{*}{ Enquêtevraag } & \multicolumn{2}{|c|}{ Gemiddelde score } \\
\hline & & Arbeidsgehandicapten & arbeidsgehandicapten \\
\hline $\begin{array}{l}\text { Kans op } \\
\text { baanverlies }\end{array}$ & $\begin{array}{l}\text { Loopt u het risico om uw baan te verliezen } \\
\text { a) Nee (0) } \\
\text { b) Ja [1] }\end{array}$ & 0,35 & 0,27 \\
\hline Onderbenutting & $\begin{array}{l}\text { Hoe sluiten uw kennis en vaardigheden aan bij uw werk? } \\
\text { a) Ik heb minder kennis en vaardigheden dan ik nodig } \\
\text { heb voor mijn werk [0] } \\
\text { b) Het sluit goed aan [0] } \\
\text { c) Ik heb meer kennis en vaardigheden dan ik nodig heb } \\
\text { voor mijn werk [1] }\end{array}$ & 0,36 & 0,33 \\
\hline $\begin{array}{l}\text { Kans op een } \\
\text { andere baan }\end{array}$ & $\begin{array}{l}\text { Ik zou gemakkelijk een nieuwe baan/functie kunnen } \\
\text { krijgen bij een andere werkgever (schaal 1=helemaal } \\
\text { niet mee eens, 5=helemaal mee eens) }\end{array}$ & 2,20 & 2,60 \\
\hline
\end{tabular}

Bron: NEA (2012)

In de analyses corrigeren we voor drie groepen controlevariabelen. Allereerst nemen we variabelen mee die iets zeggen over de kwaliteit van het arbeidsaanbod. Het betreft opleidingsniveau, jaren werkzaam bij huidige werkgever en jaren werkzaam in huidige functie. Daarnaast nemen we variabelen mee die te maken hebben met bepaalde verwachtingen die werkgevers doorgaans hebben met betrekking tot productiviteit en ziekteverlof. ${ }^{199}$ Ook nemen we de volgende standaard controlevariabelen mee: leeftijd, geslacht, burgerlijke staat, herkomst, huishoudsamenstelling, omvang dienstverband, type contract, sector, beroepsgroep en bedrijfsgrootte..$^{200}$

In tabel 5.3 worden de resultaten van deze analyses gepresenteerd. We zien dat, gecontroleerd voor het menselijk kapitaal gemeten door opleiding en ervaring, en zelf-gerapporteerde productiviteit en ziekteverlof in de afgelopen 12 maanden, de gepercipieerde kans op baanverlies en onderbenutting hoger is voor mensen met dan zonder een arbeidshandicap. Ook blijken arbeidsgehandicapten minder breed inzetbaar dan hun collega's en geven zij minder vaak aan gemakkelijk een nieuwe baan/functie te kunnen krijgen bij een andere werkgever. Omdat niet uitgesloten is dat een bepaalde negatieve houding in het algemeen (en daarmee onder andere ten aanzien van de eigen gezondheid en werk) ten grondslag ligt aan zowel het rapporteren van een arbeidshandicap als het negatief beoordelen van (subjectieve) arbeidsuitkomsten, wordt gecorrigeerd voor algemene baantevredenheid.

199 We nemen een proxy voor productiviteit mee: in-role performance gebaseerd op de volgende drie stellingen: (1) Ik behaal alle doelen (werkopdrachten die bij mijn werk horen, (2) De taken die bij mijn werk horen, gaan me goed af, (3) Ik presteer goed in mijn werk.

200 Ook is er gekeken naar de interactie tussen jaar en het al dan niet hebben van een arbeidshandicap om mogelijke veranderingen in de verbanden in de tijd te onderzoeken. Er bleken echter geen verschillen te zijn in de relatie tussen het hebben van een arbeidshandicap en de arbeidsmarktuitkomsten tussen de jaren. 
TABEL 5.3 Arbeidshandicap en subjectieve arbeidsmarktuitkomsten (2012)

\begin{tabular}{|c|c|c|c|c|c|c|}
\hline \multirow{2}{*}{$\begin{array}{l}\text { OLS } \\
\text { Arbeidshandicap }\end{array}$} & \multicolumn{2}{|c|}{$\begin{array}{c}\text { (1) } \\
\text { Kans op baanverlies }\end{array}$} & \multicolumn{2}{|c|}{$\begin{array}{c}\text { (2) } \\
\text { Onderbenutting }\end{array}$} & \multicolumn{2}{|c|}{$\begin{array}{c}\text { (3) } \\
\text { Kans op andere baan bij } \\
\text { andere werkgever }\end{array}$} \\
\hline & 0,059 & $* * *$ & 0,039 & $* * *$ & $-0,256$ & $* * *$ \\
\hline Leeftijd & 0,004 & $* * *$ & 0,000 & & $-0,022$ & $* * *$ \\
\hline Vrouw & 0,022 & $* * *$ & $-0,071$ & $* * *$ & 0,069 & $* * *$ \\
\hline \multicolumn{7}{|l|}{ Opleidingsniveau (ref=laag) } \\
\hline Midden & 0,023 & $* * *$ & 0,056 & $* * *$ & 0,111 & $* * *$ \\
\hline Hoog & 0,044 & $* * *$ & 0,061 & $* * *$ & 0,215 & $* * *$ \\
\hline Ziekteverlof & 0,002 & $* *$ & 0,001 & & $-0,006$ & $* * *$ \\
\hline Baantevredenheid & $-0,070$ & $* * *$ & $-0,083$ & $* * *$ & 0,104 & $* * *$ \\
\hline Pendeltijd & 0,043 & $* * *$ & $-0,011$ & ** & $-0,031$ & $* * *$ \\
\hline Publieke sector (ref=privaat) & $-0,040$ & $* * *$ & $-0,665$ & $* * *$ & $-0,079$ & $* * *$ \\
\hline N & \multicolumn{2}{|c|}{23.389} & \multicolumn{2}{|c|}{23.297} & \multicolumn{2}{|c|}{23.349} \\
\hline
\end{tabular}

Bron: NEA (2012)

Controlevariabelen: jaar (dummies), burgerlijke staat, herkomst, huishoudsamenstelling, omvang dienstverband, type contract, jaren werkzaam bij huidige werkgever, jaren werkzaam in huidige functie, beroepsgroep, bedrijfsgrootte.

a) Analyses waarin gecontroleerd wordt voor de uitgebreide sectorindeling zoals in figuur 5.5 leveren vergelijkbare resultaten op. Een dergelijke analyse is uitgevoerd omdat de sector overige industrie de sociale werkvoorziening omvat.

In de eerste kolom zijn de resultaten voor baanverlies gerapporteerd. De positieve correlatie tussen het hebben van een arbeidsbeperking en de gepercipieerde kans op baanverlies bevestigt het beeld dat arbeidsgehandicapten een kwetsbare positie hebben op de arbeidsmarkt, zelfs als rekening wordt gehouden met een groot aantal controlevariabelen zoals opleidingsniveau, ervaring, sector en beroepsgroep. Arbeidsgehandicapten schatten de kans om hun baan te verliezen dus hoger in dan niet-arbeidsgehandicapten. De grootte van de coëfficiënt is vergelijkbaar met hoog versus laag opgeleide werkenden. De mate waarin iemand productief is ligt mogelijk gedeeltelijk ten grondslag aan deze relatief hoge zelf ingeschatte kans op baanverlies. ${ }^{201}$ Kolom (2) gaat in op onderbenutting. Aan werknemers is gevraagd in hoeverre de kennis en vaardigheden die zij hebben aansluiten bij de vereiste kennis en vaardigheden op hun werk. Arbeidsgehandicapten blijken een hogere kans te hebben op onderbenutting dan werknemers zonder langdurige ziekte, aandoening of beperking. Dit is in lijn met eerder genoemd onderzoek naar werknemers in Engeland en Australië, waarin wordt gevonden dat werknemers met een handicap vaker een skill mismatch ervaren dan werknemers zonder handicap. ${ }^{202}$

Uit kolom (3) blijkt dat arbeidsgehandicapten hun inzetbaarheid minder goed vinden dan niet-arbeidsgehandicapten. Zeker in tijden van krimpende werkgelegenheid zou

201 Wanneer productiviteit (in-role performance) als verklarende variabele in het model voor kans op baanverlies wordt meegenomen daalt de coëfficiënt voor het hebben van een arbeidshandicap licht. De coëfficiënt blijft echter significant.

202 Jones en Sloane (2010), Disability and skill mismatch, Economic Record, Vol. 86, 101-14; Jones et al. (2011) Disability and job mismatches in the Australian labour market. IZA Discussion Paper series 6152. 
dit ertoe kunnen leiden dat arbeidsgehandicapten als eerste hun baan verliezen en meer problemen ondervinden bij het vinden van een nieuwe baan (bij eigen of andere werkgever).

De negatieve relaties tussen het hebben van een arbeidshandicap en zelf-gerapporteerde subjectieve arbeidsmarktuitkomsten zijn niet voor alle type arbeidshandicaps even sterk. Aanvullende analyses hebben aangetoond dat de negatieve relatie over het algemeen het sterkst is voor arbeidsgehandicapten met hart- en vaatziekten en met een meervoudige arbeidshandicap. ${ }^{203}$ Ook voor werkende arbeidsgehandicapten met migraine en/of een psychische aandoening zijn de gevonden relaties relatief groot. Dit is in overeenstemming met eerder onderzoek gericht op het verklaren van de loonverschillen tussen (verschillende typen) arbeidsgehandicapten en niet-arbeidsgehandicapten. ${ }^{204}$ De kans op onderbenutting blijkt alleen hoger voor arbeidsgehandicapten die lichamelijke problemen hebben en voor de groep met meervoudige aandoeningen. Voor alle andere typen arbeidsgehandicapten wordt geen significant hogere kans op onderbenutting gevonden. Dit lijkt in lijn te zijn met de uitspraak van Jones en Sloane (zie voetnoot 202) dat arbeidsgehandicapten met lichamelijke klachten minder mobiel zijn en daardoor een kleinere pool van mogelijke banen tot hun beschikking hebben zodat zij eerder een baan moeten accepteren die onder hun niveau is. Voor werkenden die beperkt worden in het uitvoeren van hun werkzaamheden door problemen met het zicht of gehoor en voor werknemers met een levensbedreigende ziekte zijn de subjectieve arbeidsmarktuitkomsten gepresenteerd in kolom 1 en 3 weliswaar nadeliger dan voor niet-arbeidsgehandicapten, maar zijn deze verschillen relatief klein.

Uit tabel 5.4 blijkt dat de verschillen in arbeidsmarktuitkomsten tussen arbeidsgehandicapten en werkenden zonder arbeidshandicap niet in elke sector even groot zijn. De coëfficiënt van de interactieterm van arbeidshandicap met publieke sector (versus private sector) laat zien dat dit verschil kleiner is voor arbeidsgehandicapten die een baan hebben in een publieke sector. Hoewel arbeidsgehandicapten in beide typen sectoren slechter af zijn dan niet-arbeidsgehandicapten (in termen van kans op baanverlies en de kans op een andere baan) is deze negatieve samenhang minder sterk voor werkenden met een arbeidshandicap in de publieke sector.

203 Getest door regressie analyses vergelijkbaar aan die gerapporteerd in tabel 5.3 maar dan met het type arbeidshandicap in plaats van de variabele arbeidshandicap ja/nee.

204 Maroto en Pettinicchio (2014). Disability, structural inequality, and work: The influence of occupational segregation on earnings for people with different disabilities. Research in Social Stratification and Mobility, 38: 76-92. 
TABEL 5.4 Arbeidshandicap en subjectieve arbeidsmarktuitkomsten coëfficiënten interactie arbeidsgehandicapt - werkzaam in publieke sector (2012)

\begin{tabular}{|c|c|c|c|c|c|c|}
\hline \multirow{2}{*}{$\begin{array}{l}\text { OLS } \\
\text { Arbeidshandicap }\end{array}$} & \multicolumn{2}{|c|}{$\begin{array}{c}\text { (4) } \\
\text { Kans op baanverlies }\end{array}$} & \multicolumn{2}{|c|}{$\begin{array}{c}\text { (5) } \\
\text { Onderbenutting }\end{array}$} & \multicolumn{2}{|c|}{$\begin{array}{c}\text { (6) } \\
\text { Kans op andere baan }\end{array}$} \\
\hline & 0,071 & $* * *$ & 0,039 & $* * *$ & $-0,026$ & $* * *$ \\
\hline Publieke sector (ref=privaat) & $-0,034$ & $* * *$ & $-0,066$ & $* * *$ & $-0,080$ & $* * *$ \\
\hline $\begin{array}{l}\text { Interactie Arbeidshandicap* } \\
\text { publieke sector }\end{array}$ & $-0,029$ & ** & $-0,008$ & & 0,094 & $* * *$ \\
\hline $\begin{array}{l}\text { Joined significance F } \\
\text { (arbeidshandicap en interactie) }\end{array}$ & 16,79 & $* * *$ & 598,06 & $* * *$ & 231,78 & $* * *$ \\
\hline $\mathrm{N}$ & \multicolumn{2}{|c|}{23.389} & \multicolumn{2}{|c|}{23.297} & \multicolumn{2}{|c|}{23.349} \\
\hline
\end{tabular}

Bron: NEA (2012)

Controlevariabelen: jaar (dummies), burgerlijke staat, herkomst, huishoudsamenstelling, omvang dienstverband, type contract, jaren werkzaam bij huidige werkgever, jaren werkzaam in huidige functie, beroepsgroep, bedrijfsgrootte.

a) Analyses waarin gecontroleerd wordt voor de uitgebreide sectorindeling zoals in figuur 5.5 leveren vergelijkbare resultaten op. Een dergelijke analyse is uitgevoerd omdat de sector overige industrie de sociale werkvoorziening omvat.

\subsection{Arbeidsmarktperspectieven}

In deze paragraaf komen de arbeidsmarktperspectieven voor verschillende sectoren en opleidingsachtergronden aan bod, waarbinnen het aandeel arbeidsgehandicapten relatief hoog ligt. ${ }^{205,206}$

Allereerst wordt het percentage arbeidsgehandicapten per sector zoals weergegeven in figuur 5.8 gerelateerd aan de sectorprognoses uit tabel 1.3. Dit verschaft inzicht in de mate waarin arbeidsgehandicapten vertegenwoordigd zijn in groei/krimpsectoren in de komende zes jaar.

205 Zie voor een vergelijkbare studie Sanders, de Vos en Besseling (2009), 'Re-integratie met perspectief. Een verkenning van de arbeidsmarktpositie, arbeidsmarktperspectieven en kansrijke beroepen voor re-integratie voor AO-uitkeringsgerechtigden' van TNO. In tegenstelling tot het onderzoek van TNO zullen wij niet ingaan op de uitkeringsgerechtigden maar op de arbeidsgehandicapten zoals eerder gedefinieerd.

206 Het percentage arbeidsgehandicapten dat in deze paragraaf vermeld wordt is van 2013 (met bijbehorende definitie van de werkenden, 15-65 met minimaal 12 uur). Dit is niet in overeenstemming met de prognoses, waarvoor de ILO-definitie geldt en waarbij 2014 het basisjaar is. De percentages arbeidsgehandicapten per sectorblijken echter niet veel af te wijken wanneer we de kleine banen wel meenemen. Bovendien is er door een wijziging in de vraagstelling naar arbeidsgehandicapten in de EBB sinds 2014, gekozen om net als in de rest van dit hoofdstuk het percentage arbeidsgehandicapten uit 2013 te gebruiken. 
FIGUUR 5.8 Relatie uitbreidingsvraag en percentage arbeidsgehandicapten naar sector

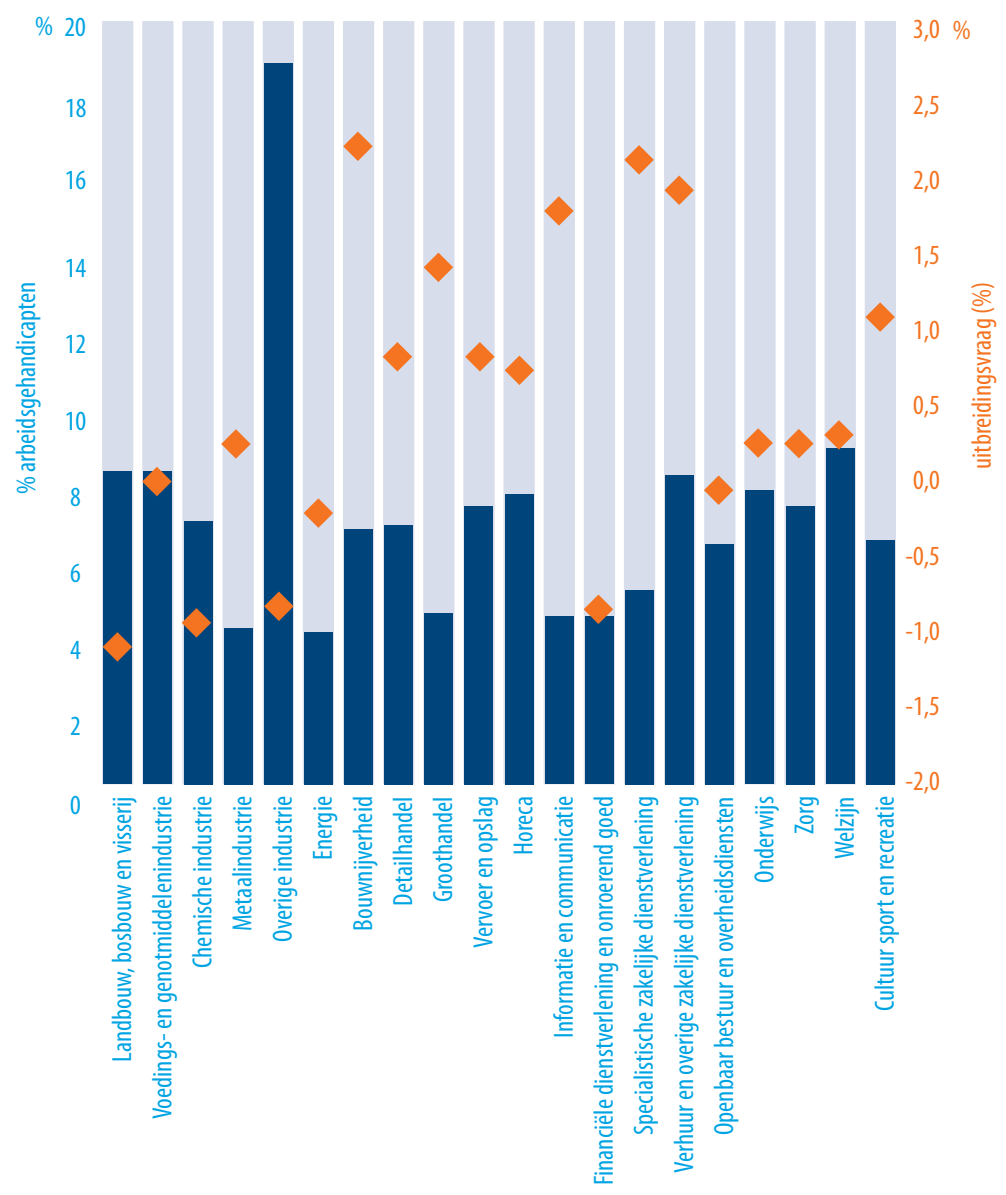

Bron: EBB (2013), ROA (AIS)

Uit de figuur blijkt dat de vier sectoren met de meeste arbeidsgehandicapten - overige industrie, welzijn, voedings- en genotmiddelenindustrie en landbouw, bosbouw en visserij - de komende jaren een negatieve of kleine positieve uitbreidingsvraag hebben. Om twee redenen is dit niet gunstig voor de arbeidsgehandicapten. Allereerst wil dit zeggen dat het moeilijk kan zijn voor de werkende arbeidsgehandicapten om hun baan in de sector te behouden, en ten tweede kan het voor arbeidsgehandicapten die de arbeidsmarkt op gaan moeilijk zijn om een baan in die sectoren te vinden waarin in 2013 relatief veel arbeidsgehandicapten werkten. Echter, de sector verhuur en overige zakelijke dienstverlening telt relatief gezien ook bovengemiddeld veel arbeidsgehandicapten, en voor deze sector wordt juist een relatief grote uitbreidingsvraag verwacht. Met andere woorden, in deze sector is het de verwachting dat er relatief veel werkgele- 
genheidsgroei zal plaatsvinden de komende jaren en dit biedt mogelijk goede perspectieven voor de arbeidsgehandicapten.

Om preciezer in te gaan op de perspectieven voor arbeidsgehandicapten gaan we in figuur 5.9 in op de relatie tussen de ITA en het percentage arbeidsgehandicapten per opleidingscategorie. Het is belangrijk op te merken dat hoe lager de ITA is, hoe beter het perspectief voor werkenden met de bijbehorende opleidingsachtergrond. Voor wo techniek zijn de perspectieven dus het best (zoals ook vermeld in hoofdstuk 3, tabel 3.7). Eerder kwam al aan bod dat voor deze opleidingscategorie het laagste aandeel arbeidsgehandicapten gemeten wordt. Daarnaast geldt dat van alle opleidingscategorieën, de arbeidsmarktperspectieven voor personen met een mbo 2/3 zorg en welzijn diploma het slechtst zijn, en werkende arbeidsgehandicapten hier juist het grootste aandeel uitmaken. Over de hele linie vinden we een positieve relatie tussen de ITA's en het percentage arbeidsgehandicapten. Dat wil zeggen dat daar waar relatief gezien de meeste arbeidsgehandicapten aan het werk zijn, de perspectieven het slechtst zijn.

\section{FIGUUR 5.9 Relatie ITA en percentage arbeidsgehandicapten naar opleidingscategorie}

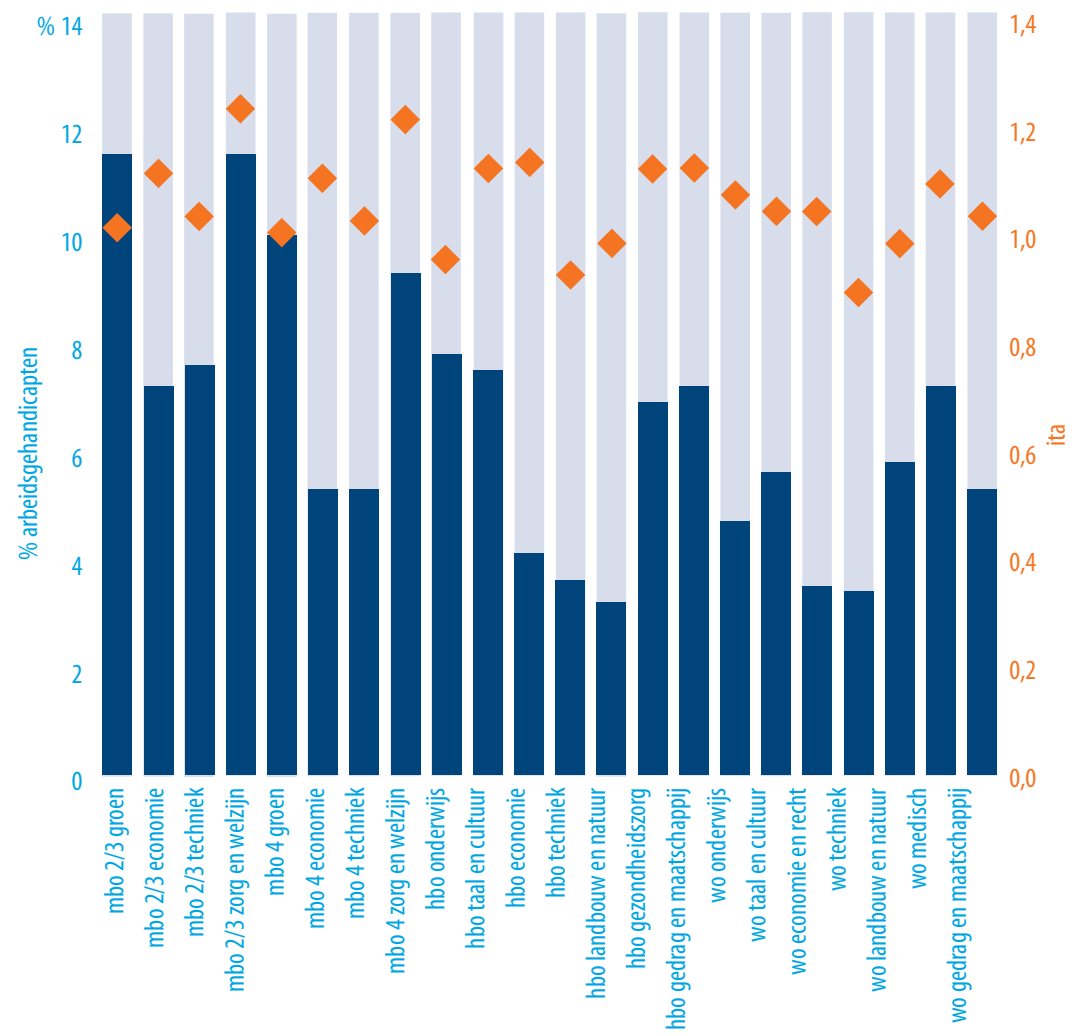

Bron: EBB (2013), ROA (AIS) 
Tabel 5.5 vat de arbeidsmarktperspectieven samen van arbeidsgehandicapten en nietarbeidsgehandicapten, voor werkenden en werklozen afzonderlijk. Het is belangrijk te benadrukken dat het arbeidsmarktperspectief hier enkel wordt bepaald aan de hand van de opleidingsachtergrond en de daarbij horende verwachte verhoudingen in vraag en aanbod tot 2020 (zie figuur 5.9). Het is echter mogelijk dat andere kenmerken ook bepalend zijn bij de kansen op de arbeidsmarkt (denk bijvoorbeeld aan ernst van de handicap, verschillen in ervaring tussen arbeidsgehandicapten en niet-gehandicapten, subsidiemogelijkheden, regelgeving, etc.). Er is hier geen rekening gehouden met deze verschillen en de resultaten moeten dan ook vooral als exploratief worden beschouwd.

TABEL 5.5 Percentage personen met op basis van hun opleidingsachtergrond een goed, redelijk, matig of slecht arbeidsmarktperspectief (ITA)

\begin{tabular}{|l|l|r|r|r|}
\hline \multirow{3}{*}{ werkenden } & \multicolumn{3}{|c|}{ ITA-typering } \\
& & matig/slecht & redelijk & goed/zeer goed \\
\cline { 2 - 5 } & arbeidsgehandicapten & 49 & 18 & 33 \\
\cline { 2 - 5 } werklozen & niet-arbeidsgehandicapten & 46 & 20 & 34 \\
& verschil in \%-punten & 3 & -2 & -1 \\
\hline & arbeidsgehandicapten & 41 & 17 & 42 \\
& niet-arbeidsgehandicapten & 43 & 17 & 40 \\
\hline
\end{tabular}

Bron: ROA (AIS)

Voor de werkenden geldt in het algemeen - dus voor zowel arbeidsgehandicapten als niet-arbeidsgehandicapten - dat het grootste aandeel (bijna de helft) matige tot slechte arbeidsmarktperspectieven heeft, afgaand op hun opleidingsachtergrond. lets meer dan een derde behoort tot een opleidingstype met (zeer) goede perspectieven en voor minder dan één op de vijf zijn de vooruitzichten redelijk. Verder laat tabel 5.5 voor de werkenden zien dat arbeidsgehandicapten vaker dan niet-arbeidsgehandicapten een opleidingstype hebben waarvoor matige tot slechte arbeidsmarktperspectieven worden verwacht (verschil van 3\%-punt). Tegelijkertijd hebben zij minder vaak dan niet-arbeidsgehandicapten een opleidingstype waarvoor de arbeidsmarktperspectieven goed zijn (verschil van -1\%-punt). De nadelige positie van werkende arbeidsgehandicapten ten opzichte van niet-arbeidsgehandicapten met een baan komt dus tot uiting in hun huidige positie (zij geven aan problemen te hebben bij het behouden van hun werk), maar ook in de prognosecijfers die slechtere vooruitzichten laten zien voor werkende arbeidsgehandicapten dan voor niet-arbeidsgehandicapten.

Voor de werklozen constateren we het tegenovergestelde. Binnen deze groep hebben arbeidsgehandicapten minder vaak dan niet-arbeidsgehandicapten een opleidingstype met matige tot slechte perspectieven (verschil van -2\%-punt) en juist vaker een opleidingstype met goede perspectieven (verschil van 2\%-punt). Met andere woorden wijzen bovenstaande cijfers erop dat - enkel op basis van opleidingsachtergrond - voor werkloze arbeidsgehandicapten betere arbeidsmarktperspectieven worden voorzien dan voor werkloze niet-arbeidsgehandicapten. Deze vaststelling berust op de assumptie 
dat arbeidsmarktkansen niet verschillen tussen een arbeidsgehandicapte en een nietarbeidsgehandicapte met eenzelfde opleidingstype. Arbeidsgehandicapten zullen echter zeer waarschijnlijk (gemiddeld) genomen moeilijker aan het werk komen door hun langdurige ziekte, aandoening of beperking. Bovendien zijn arbeidsgehandicapten gemiddeld genomen ouder, wat de arbeidsmarktkansen negatief beïnvloedt. Daarnaast kennen arbeidsgehandicapten mogelijk een langere gemiddelde werkloosheidsduur dan voor niet-arbeidsgehandicapten. De duur van de werkloosheid zal eveneens invloed hebben op de arbeidsmarktkansen.

\subsection{Conclusie}

In de periode 2006-2013 is de werkloosheid onder arbeidsgehandicapten opgelopen van 10,4 naar 15,8\% en onder niet-arbeidsgehandicapten van 4,9 naar 7,6\% Het werkloosheidspercentage onder arbeidsgehandicapten was in 2013 (afgerond 16\%) vergelijkbaar met dat onder personen die enkel basisonderwijs hebben genoten. Arbeidsgehandicapten kennen dus een kwetsbare positie op de Nederlandse arbeidsmarkt.

In dit hoofdstuk is allereerst ingegaan op de vraag in welke sectoren, beroepen en banen arbeidsgehandicapten werkzaam zijn. De meeste arbeidsgehandicapten zijn werkzaam in de industrie, de landbouw, bosbouw en visserij en in de gezondheids- en welzijnszorg. Bovendien zijn zij meestal werkzaam in beroepen met een relatief laag opleidingsniveau zoals landbouwers, bosbouwers en vissers, elementaire beroepen en bedieners machines en installaties, assemblagemedewerkers. Dit is een duidelijke weerspiegeling van een lager opleidingsniveau onder de arbeidsgehandicapten dan onder de niet-arbeidsgehandicapten. Arbeidsgehandicapten typeren de werkzaamheden die zij verrichten anders dan werkenden zonder arbeidshandicap. Gemiddeld genomen ervaren arbeidsgehandicapten een lagere mate van autonomie in hun baan en beoordelen zij hun werk als minder gevarieerd en innovatief dan niet-arbeidsgehandicapten. Arbeidsgehandicapten geven vaker dan niet-arbeidsgehandicapten aan dat zij soms of regelmatig gevaarlijk werk verrichten.

Analyses op basis van de NEA (2008-2012) bevestigen het beeld dat arbeidsgehandicapten er minder goed voorstaan op de arbeidsmarkt dan niet-arbeidsgehandicapten. Gecorrigeerd voor vele factoren zoals opleiding, ervaring, sector en beroepsgroep, blijken arbeidsgehandicapten vaker te maken te hebben met subjectieve onderbenutting, zijn ze minder breed inzetbaar, hebben ze een lagere in-role performance en zijn ze vaker met ziekteverlof. Bovendien zijn zij minder tevreden met hun baan dan niet-arbeidsgehandicapten. Deze negatieve relaties tussen het hebben van een arbeidshandicap aan de ene kant en de (zelf-gerapporteerde) subjectieve arbeidsmarktuitkomsten aan de andere kant blijken het sterkst aanwezig voor arbeidsgehandicapten met een psychische beperking en voor hen die meerdere aandoeningen hebben. Dit is in 
overeenstemming met literatuur die zich richt op het verklaren van de loonverschillen tussen (verschillende typen) arbeidsgehandicapten en niet-arbeidsgehandicapten.

De bevindingen uit dit hoofdstuk wijzen erop dat arbeidsgehandicapten zowel langs de lijn als binnen de arbeidsmarkt kwetsbaar zijn en dat dit geldt voor zowel werkenden als werkzoekenden. Aan de ene kant hebben zij een kleinere kans om daadwerkelijk werkzaam te zijn (en te blijven in tijden van economische crisis), aan de andere kant blijken werkende arbeidsgehandicapten minder goede kwalitatieve arbeidsmarktuitkomsten te kennen dan niet-arbeidsgehandicapten. Deze bevindingen zijn bijzonder relevant in het licht van de invoering van de Participatiewet die op 1 januari 2015 in werking is getreden.

Het is belangrijk om ervoor te zorgen dat arbeidsgehandicapten in beroepen/sectoren worden ingezet waar zij op termijn ook de beste kansen hebben om aan het werk te blijven. Bij het re-integratietraject van niet-werkzame arbeidsgehandicapten moet rekening worden gehouden met de arbeidsmarktperspectieven. Dit hoofdstuk biedt een exploratie naar de arbeidsmarktperspectieven van arbeidsgehandicapten ten opzichte van niet-arbeidsgehandicapten. De vier sectoren met de meeste arbeidsgehandicapten - overige industrie, welzijn, landbouw, bosbouw en visserij en voedings- en genotmiddelenindustrie - zullen de komende jaren een negatieve of kleine uitbreidingsvraag hebben. Het positieve nieuws is dat er een relatief veel werkgelegenheidsgroei zal plaatsvinden in de sector verhuur en overige zakelijke dienstverlening waarin ook bovengemiddeld veel arbeidsgehandicapten werkzaam zijn.

Voor werklozen geldt dat arbeidsgehandicapten vaker een opleidingsachtergrond hebben waarvoor betere arbeidsmarktperspectieven worden verwacht dan voor nietarbeidsgehandicapten. Het is echter goed te bedenken dat zij, ondanks hun gunstige opleidingsachtergrond, in een nadeligere positie verkeren dan werkzoekenden met een soortgelijke opleidingsachtergrond en zonder beperking. Hierbij moet ook in acht worden genomen dat het aantal baanopeningen tot 2020 naar verwachting gering is en er dus sprake zal zijn van concurrentie tussen degenen die zich aanbieden op de arbeidsmarkt. Het zal voor arbeidsgehandicapten dus relatief moeilijk blijven om een baan te vinden, niet in de laatste plaats omdat zij doorgaans aan het eind van de rij van werkzoekenden staan en daarmee als laatst in aanmerking komen voor een baan. ${ }^{207}$

207 Thurow, L. (1975), Generating Inequality: Mechanisms of Distribution in the U.S. Economy. New York: Basic Books. 


\section{BIJLAGE A CENTRALE BEGRIPPEN BIJ DE ARBEIDSMARKTPROGNOSES}

\section{Allochtoon}

Het begrip allochtoon wordt gehanteerd volgens de (nieuwe) standaarddefinitie van het CBS. De definitie van allochtoon heeft betrekking op iedereen waarvan ten minste één ouder in het buitenland is geboren. Het buitenland is daarbij op te splitsen in westerse en niet-westerse herkomstlanden. Tot de niet-westerse herkomstlanden worden gerekend Turkije en alle landen in Afrika, Latijns-Amerika en Azië (met uitzondering van Japan en Indonesië). De definitie van de allochtonen naar herkomst heeft in dit rapport betrekking op de niet-westerse herkomstlanden.

\section{Arbeidsmarktinstroom van schoolverlaters}

Het aanbod van nieuwe arbeidskrachten op de arbeidsmarkt, zoals deze is bepaald door de verwachte uitstroom van schoolverlaters uit het initiële dagonderwijs, de schoolverlaters van het deeltijdonderwijs, het niet-reguliere voltijdonderwijs en de beroepsgerichte volwasseneneducatie. Daarbij wordt de benaming 'schoolverlater' meestal ook gehanteerd voor de afgestudeerden van het hoger onderwijs.

\section{Publicaties:}

A. de Grip en A. Jacobs (1999), De doorstroom van het initieel naar het niet-initieel onderwijs, ROA-W-1999/3, Universiteit Maastricht.

F. Cörvers en B. Golsteyn (2003), De invloed van voortijdige schooluitval op de instroomprognoses van schoolverlaters op de arbeidsmarkt, ROA-W-2003/1, Universiteit Maastricht.

\section{Arbeidsvolume}

Het totaal aantal arbeidsjaren, waarbij is uitgegaan van een werkweek van 40 uur.

\section{Baanopeningen}

De totale vraag naar nieuwkomers op de arbeidsmarkt, zoals deze is bepaald door de werkgelegenheidsgroei (positieve uitbreidingsvraag) en de vervangingsvraag. Bij het vaststellen van het aantal baanopeningen wordt ermee rekening gehouden dat het 
aannemen van schoolverlaters door bedrijven en instellingen ('de vraag naar schoolverlaters') op nagenoeg hetzelfde niveau blijft ondanks een eventuele werkgelegenheidskrimp vanwege de extra uitstroom van ouderen. Het blijkt dat werkgevers voor het realiseren van een teruglopende vraag naar arbeid aan de 'exit'-optie de voorkeur geven boven de 'no entry'-optie van bijvoorbeeld schoolverlaters. Een werkgelegenheidskrimp voor een opleidingstype of beroepsgroep gaat derhalve nauwelijks ten koste van de vervangingsvraag of het aantal baanopeningen in een opleidingstype of beroepsgroep.

\section{Publicaties:}

A. de Grip, P. Meijboom and E. Willems (1994), 'Vacancies, Employment Growth and the Demand for Newcomers on the Labour Market', in: J. Muijsken (ed.), Measurement and Analysis of Job Vacancies, Avebury, Aldershot/Brookfield (USA), pp. 101-125.

E. Willems, L. Borghans and A. de Grip (1997), Exit or no entry? Replacement demand and shrinking employment, ROA, Paper for the EALE conference, Aarhus, Denmark.

\section{Bedrijfssector}

De in dit rapport gepresenteerde informatie is veelal verbijzonderd naar 21 bedrijfssectoren (zie Bijlage B). Deze indeling is gebaseerd op de Standaard Bedrijfsindeling 2008 (SBI'08) van het CBS.

\section{Beroepsgroep}

In dit rapport wordt uitgegaan van 113 beroepsgroepen over de volle breedte van de arbeidsmarkt. Deze zijn geclusterd tot 12 beroepsklassen (plus 1 groep en de klasse voor 'overig', zie Bijlage B). De indeling is afgeleid van de ISCO beroepen en tot stand gekomen in samenwerking met CBS.

\section{Publicaties}

ROA (2015), Beroepenindeling ROA-CBS 2014 (BRC 2014), Maastricht: ROA-TR-2015/5.

\section{Beroepsbevolking}

De beroepsbevolking omvat de werkenden en de werkzoekenden zonder baan. ledereen met een leeftijd tussen de 15 en 74 jaar, die minstens 11 uur per week betaalde arbeid verricht (werkzame beroepsbevolking) of recent naar betaald werk heeft gezocht en daarvoor direct beschikbaar is (werkloze beroepsbevolking). De definitie van de beroepsbevolking zijn afkomstig van het CBS (www.cbs.nl).

\section{Conjunctuurgevoeligheid}

De conjunctuurgevoeligheid van de werkgelegenheid heeft betrekking op de mate waarin de werkgelegenheid in een beroepsgroep, of voor mensen met een bepaalde 
opleidingsachtergrond, gevoelig is voor veranderingen van de economische situatie. Deze indicator geeft daarmee de mate van werkzekerheid aan. De conjunctuurgevoeligheid wordt bepaald door de sectorale werkgelegenheidsfluctuaties in het verleden te relateren aan de mate waarin een beroepsgroep of opleidingstype momenteel in de verschillende bedrijfssectoren is vertegenwoordigd. Hierbij wordt rekening gehouden met het feit dat niet ieder beroep even sterk meefluctueert met de werkgelegenheidsschommelingen van de bedrijfssector.

\section{Flexibele arbeidsrelatie}

Van een flexibele arbeidsrelatie is sprake bij uitzendkrachten, oproepkrachten, invalskrachten, contracten zonder een vast aantal arbeidsuren en indien geen vast dienstverband is overeengekomen. Een arbeidscontract wordt als niet-vast beschouwd als de contractuele termijn van beperkte duur is.

\section{Publicatie:}

F. Cörvers, J. van Thor (2010), Flexwerk in Nederland, ROA-TR-2010/2, Universiteit Maastricht.

\section{Knelpunten in de personeelsvoorziening naar beroep}

Om inzicht te verschaffen hoe de aansluitingsproblematiek tussen onderwijs en arbeidsmarkt zijn weerslag heeft op de wervingsproblematiek in de verschillende beroepsgroepen, wordt gebruik gemaakt van de Indicator Toekomstige Knelpunten in de Personeelsvoorziening naar Beroep (ITKB). De ITKB geeft aan in welke mate het voor werkgevers mogelijk is om de gewenste personeelssamenstelling naar opleidingsachtergrond binnen beroepsgroepen te realiseren, bij de voorspelde vraag-aanbod-verhoudingen voor de verschillende opleidingstypen. De ITKB heeft een waarde tussen o en 1. Naarmate de waarde van de indicator lager is, zijn de knelpunten in de personeelsvoorziening voor de betreffende beroepsgroep groter. Werkgevers zullen dan relatief veel moeite hebben nieuw personeel met de door hen gewenste opleidingsachtergrond te vinden. Wanneer de ITKB daarentegen bijna gelijk is aan 1, zullen werkgevers weinig moeite hebben de gewenste personeelssamenstelling binnen het beroep te realiseren. Voor die opleidingen die aandacht schenken aan de in dat beroep relevante kennis en vaardigheden, worden dan geringe knelpunten verwacht.

\section{Knelpunten in de personeelsvoorziening naar opleiding}

Als de vraag naar werkenden met een bepaalde opleidingsachtergrond groter is dan het aanbod kunnen knelpunten in de personeelsvoorziening voor werkgevers verwacht worden. Vergelijkbaar met de Indicator Toekomstig Arbeidsmarktperspectief (ITA) geeft de Indicator van de Toekomstige Knelpunten in de Personeelsvoorziening (ITKP) deze vraag-aanbod-spanning per opleidingstype aan. Verschil met de ITA is dat bij de ITKP de uitstroom van werkenden als gevolg van een krimpende werkgelegenheid is meege- 
rekend in de vraag, omdat verwacht mag worden dat bij knelpunten in de personeelsvoorziening deze (gedwongen) uitstroom kan worden afgeremd of elders werk zou kunnen vinden. Naarmate de waarde van de indicator lager wordt, zijn de verwachte knelpunten groter.

\section{Onderbenutting}

Een indicatie van de mate waarin arbeidskrachten werkzaam zijn op een functieniveau dat lager is dan hun opleidingsniveau. De mate van onderbenutting is vastgesteld door de schoolverlaters aan te laten geven in hoeverre de werkgever het verworven opleidingsniveau vereist voor de uitgeoefende functie.

\section{Publicatie:}

J. Coenen, F. Cörvers, D. Fouarge, C. Meng, A. Nelen (2009), 'Onderbenutting van mbo'ers nuttig op de arbeidsmarkt?', TPEdigitaal, Vol. 3, pp. 103-123.

\section{Opleidingstype}

Alle voorkomende opleidingen zijn samengevoegd tot een aantal clusters. In dit rapport worden 96 opleidingstypen onderscheiden (inclusief opleidingstype 'overig'). Deze zijn geclusterd tot 29 opleidingscategorieën, inclusief de categorie 'overig' (zie Bijlage B). De opleidingsindeling is afgeleid van ISCED.

\section{Potentiële beroepsbevolking}

De potentiële beroepsbevolking omvat alle personen tussen de 15 en de 74 jaar, voor zover hun belangrijkste activiteit niet studie betreft. Scholieren en studenten worden dus niet tot de potentiële beroepsbevolking gerekend. De potentiële beroepsbevolking omvat daarmee naast de beroepsbevolking ook de niet-participerenden.

\section{Startkwalificatie}

Het Nederlandse onderwijsbeleid is erop gericht om jongeren minimaal een startkwalificatie te laten behalen, dat wil zeggen een opleiding overeenkomend met niveau 2 (basisberoepsbeoefenaar) van de kwalificatiestructuur voor de beroepsopleidende leerweg $(\mathrm{BOL})$ en de beroepsbegeleidende leerweg (BBL) van het secundair beroepsonderwijs. Ook de tweede fase VO (HAVO of VWO) leidt tot een startkwalificatie. Globaal betekent dit dat na het verlaten van het VMBO nog een beroepsopleiding moet worden gevolgd via de $\mathrm{BOL}$ of de BBL met een minimale opleidingsduur van 2 jaar (voorheen tweejarig KMBO respectievelijk primair leerlingwezen). De startkwalificatie - of het niveau van basisberoepsbeoefenaar - wordt gezien als het niveau dat minimaal noodzakelijk is om op een goede manier te kunnen functioneren op de snel veranderende arbeidsmarkt. De grens tussen wel of geen startkwalificatie is vanuit arbeidsmarktoptiek gelegen rond niveau 1 of 2 . De verschillende niveaus binnen het MBO kunnen in 
dit rapport meestal niet als zodanig worden onderscheiden. Om deze reden wordt een opleiding op MBO-niveau 2, 3 of 4 doorgaans beschouwd als een startkwalificatie voor de arbeidsmarkt, tenzij anders is aangegeven. Alle opleidingen van MBO-niveau 1 (assistent beroepsbeoefenaar) zijn in dit rapport ingedeeld op VMBO-niveau.

\section{Publicaties:}

R. van der Velden, R. de Vries, M. Wolbers en P. van Eijs (2002), De waarde van een startkwalificatie, ROA-R-2002/14, Universiteit Maastricht.

W.A. Houtkoop, R.K.W. van der Velden en T.F. Brandsma (2004), De waarde van de startkwalificatie, Max Goote bve, mei.

\section{Substitutie-effect (passief en actief)}

Als gevolg van discrepanties tussen vraag en aanbod op de arbeidsmarkt treden er verschuivingen op in de werkgelegenheidsstructuur. Schoolverlaters in een aanbodoverschotsituatie kunnen anders opgeleiden gaan verdringen, terwijl werkgevers die te kampen hebben met een tekortschietend arbeidsaanbod, personen met een andere opleidingsachtergrond kunnen gaan werven. De vraag die hierdoor verloren gaat of ontstaat wordt aangeduid als het passieve substitutie-effect. Als het passieve substitutie-effect positief is, gaat het om extra baanopeningen als gevolg van tekorten bij andere opleidingen. Een negatief substitutie-effect duidt daarentegen op een verlies aan baanopeningen, omdat men verdrongen wordt door andere opleidingen. Het actieve substitutie-effect geeft - als het positief is - aan in hoeverre werkenden met een opleidingsachtergrond waarvoor er een aanbodoverschot is door een verhevigde concurrentie alsnog werk zullen vinden door arbeidskrachten met een andere opleidingsachtergrond te verdringen. Een negatieve actieve substitutie geeft daarentegen aan welke werkgelegenheid niet meer vervuld zal worden als gevolg van de verwachte aanbodtekorten.

\section{Publicaties:}

L. Borghans and H. Heijke (1994), 'Forecasting the educational structure of occupations: A manpower requirement approach with substitution', Labour, Vol. 10, pp. 151-192.

A. de Grip, L. Borghans and W. Smits (1998), 'Future developments in the job level and domain of highly-skilled workers', in: H. Heijke, L. Borghans (eds), Towards a transparent Labour Market for Educational Decisions, Ashgate, Aldershot/Brookfield USA/Singapore/ Sydney, pp. 21-56.

F. Cörvers and H. Heijke (2004), Forecasting the labour market by occupation and education: Some key issues, ROA-W-2004/4, Universiteit Maastricht.

\section{Substitutiemogelijkheden bij de personeelswerving}

De mate waarin werkgevers voor een bepaald beroep arbeidskrachten kunnen aantrekken met een uiteenlopende opleidingsachtergrond, zodat ze niet afhankelijk zijn 
van het arbeidsaanbod van een bepaald opleidingstype. De substitutiemogelijkheden worden bepaald met behulp van een spreidingsindex.

\section{Toekomstig arbeidsmarktperspectief naar opleiding}

Het toekomstig arbeidsmarktperspectief geeft de verhouding tussen aanbod en vraag in de prognoseperiode voor een opleidingstype weer. De vraag- en aanbodprognoses zijn gebaseerd op de actuele arbeidsmarktpositie van een opleiding. Als het arbeidsmarktperspectief van een opleiding slecht is, betekent dit dat er de komende jaren veel meer aanbod van nieuwkomers is dan baanopeningen. Hierdoor zal de arbeidsmarktpositie gaan verslechteren. Deze verslechtering kan een hogere werkloosheid betekenen, maar door aanpassingsprocessen op de arbeidsmarkt kan de verslechtering van de arbeidsmarktsituatie ook leiden tot het moeten aanvaarden van banen op een lager niveau, een lagere beloning en meer tijdelijke contracten. Omgekeerd zal een goed perspectief leiden tot een grotere kans op werk, maar ook tot een verbeterde positie op andere punten. Het toekomstig arbeidsmarktperspectief per opleidingstype wordt bepaald door middel van de Indicator Toekomstig Arbeidsmarktperspectief (ITA), die is gedefinieerd als de verhouding tussen enerzijds de verwachte arbeidsmarktinstroom van schoolverlaters en het aantal kortdurig werklozen en anderzijds de verwachte baanopeningen en de passieve substitutievraag. Naarmate de waarde van de indicator hoger is wordt het perspectief slechter.

\section{Publicaties:}

M.H. Wieling, A. de Grip en E.J.T.A. Willems (1990), Een systematische kwalitatieve typering van arbeidsmarktinformatie, ROA-W-1990/8, Universiteit Maastricht.

F. Cörvers, A. de Grip and H. Heijke (2002), 'Beyond manpower planning: a labour market model for the Netherlands and its forecasts to 2006', in M. Neugart and K. Schömann (eds), Forecasting Labour Markets in OECD Countries, Cheltenham (UK) and Northampton MA (USA), Edward Elgar, pp. 185-223.

A. Dupuy (2009), An evaluation of the indicator of the labour market gap, ROA-TR-2009/1, Universiteit Maastricht.

\section{Uitbreidingsvraag}

De vraag naar nieuwe arbeidskrachten die ontstaat door groei van de werkgelegenheid. Als er sprake is van een werkgelegenheidsdaling, is de uitbreidingsvraag negatief.

\section{Publicaties:}

F. Cörvers and A. Dupuy (2006), Explaining the Occupational Structure of Dutch Sectors of Industry, 1988-2003, ROA-W-2006/7E, Universiteit Maastricht.

F. Cörvers en A. Dupuy (2007), Beroepenmodel voor het onderwijs en de zorg: werkgelegenheid en prognoses, ROA-W-2007/3, Universiteit Maastricht.

F. Cörvers and A. Dupuy (2010), 'Estimating employment dynamics across occupations and sectors of industry', Journal of Macroeconomics, Vol. 32, pp. 17-27. 
D. Bertrand-Cloodt (2010), Evaluatie uitbreidingsvraag en indicator toekomstige arbeidsmarktsituatie (ITA) tot 2008, ROA-TR-2010/6, Universiteit Maastricht.

\section{Uitwijkmogelijkheden}

De mate waarin arbeidskrachten met een bepaalde opleidingsachtergrond of met een bepaald beroep terecht kunnen komen in andere beroepsgroepen op een aansluitend of hoger functieniveau, respectievelijk in andere bedrijfssectoren. Deze maatstaf geeft daarmee aan in hoeverre arbeidskrachten afhankelijk zijn van de arbeidsmarktsituatie in een bepaald beroep of een bepaalde bedrijfssector. De uitwijkmogelijkheden worden bepaald met behulp van een spreidingsindex. Deze index geeft een indicatie van het aantal beroepsgroepen of bedrijfssectoren waarnaar men kan uitwijken.

\section{Publicatie:}

L. Borghans and H. Heijke (1998),'Flexibility and the Structure of the Dutch Labour Market', in: H. Heijke, L. Borghans (eds), Towards a transparent Labour Market for Educational Decisions, Ashgate, Aldershot/Brookfield USA/Singapore/Sydney, pp. 119-150.

\section{Upgrading}

Door een toenemende complexiteit van de te verrichten werkzaamheden kunnen er voor een bepaald beroep door werkgevers hogere opleidingseisen worden gesteld. In dat geval spreekt men van upgrading van de kwalificatie-eisen. Overigens kan ook een verschuiving van de werkgelegenheid van lagere naar hogere beroepen als een upgradingsproces worden getypeerd.

\section{Publicaties:}

L. Borghans and A. de Grip (2000), Skills and Low Pay: 'Upgrading or Overeducation?', in: M. Gregory, W. Salverda and S. Bazen (eds), Labour Market Inequalities, Problems and Policies of Low-Wage Employment in International Perspective, Oxford University Press, Oxford, pp. 198-223.

A. Dupuy (2006), Measuring Skill-upgrading in the Dutch Labor Market, ROA-W-2006/3E, Universiteit Maastricht.

A. Dupuy (2007), 'Will the skill-premium in the Netherlands rise in the next decades?', Applied Economics, Vol. 39, pp. 2723-2731.

\section{Verdringing}

Indien de arbeidskrachten met een bepaalde opleidingsachtergrond vanwege een aanbodoverschot bij een ander opleidingstype, te kampen hebben met een dalend werkgelegenheidsaandeel in de beroepen waarin zij werkzaam zijn, is er sprake van verdringing. Meer technisch wordt dit ook wel aangeduid als een negatief passief substitutie-effect. Bij het opleidingstype dat de anders opgeleiden verdringt is er sprake van een positief actief substitutie-effect. 


\section{Publicaties:}

A. de Grip, L. Borghans and W. Smits (1998), 'Future developments in the job level and domain of highly-skilled workers', in: H. Heijke, L. Borghans (eds), Towards a transparent Labour Market for Educational Decisions, Ashgate, Aldershot/Brookfield USA/Singapore/ Sydney, pp. 21-56.

F. Cörvers and H. Heijke (2004), Forecasting the labour market by occupation and education: Some key issues, ROA-W-2004/4, Universiteit Maastricht.

\section{Vervangingsvraag}

De vraag naar nieuwe arbeidskrachten die ontstaat doordat de arbeidsplaatsen van werkenden die met pensioen gaan, arbeidsongeschikt worden of zich (tijdelijk) terugtrekken van de arbeidsmarkt opnieuw moeten worden opgevuld. De vervangings-vraag per beroepsgroep kan bovendien ontstaan door de beroepsmobiliteit. De vervangingsvraag naar opleidingstype kan bovendien ontstaan wanneer arbeidskrachten door middel van niveauverhogende of richtingveranderende scholing aanvullende kwalificaties weten te verwerven. Vertrek van werkenden dat niet leidt tot vraag naar nieuwkomers uit hetzelfde opleidingstype of dezelfde beroepsgroep wordt niet meegerekend als vervangingsvraag.

\section{Publicaties:}

E.J.T.A. Willems and A. de Grip (1993), 'Forecasting Replacement Demand by Occupation and Education', International Journal of Forecasting, Vol. 9, pp. 173-185.

E. Willems (1999), Modelling Replacement Demand: A Random Coefficient Approach, ROA-RM-1999/2E, Universiteit Maastricht.

F. Cörvers, B. Kriechel en R. Montizaan (2006), Scenario-analyse van de vervangingsvraag tot 2010, ROA-W-2006/1, Universiteit Maastricht.

R. Montizaan (2009), Evaluatie vervangingsvraagprognoses naar opleiding en beroep, ROA-TR-2009/1, Universiteit Maastricht.

\section{Werkloosheid}

Werklozen zijn personen tussen de 15 en de 74 jaar die geen betaald werk hebben, maar wel recent naar werk hebben gezocht en daarvoor direct beschikbaar zijn (www.cbs. $\mathrm{nl})$. Het werkloosheidspercentage wordt bepaald door het aantal werklozen te relateren aan de beroepsbevolking. Kortdurig werklozen worden gedefinieerd als personen die minder dan een jaar werkloos zijn. 


\section{BIJLAGE B CLASSIFICATIES NAAR BEDRIJFSSECTOR, BEROEP EN OPLEIDING}

\section{Bedrijfssectoren}

Landbouw, bosbouw,en visserij

Voedings- en genotmiddelenindustrie

Chemische industrie

Metaalindustrie

Overige industrie

Energie en Delfstoffewinning

Bouwnijverheid

Detailhandel en Autohandel

Groothandel en handelsbemiddeling

Vervoer en opslag

Horeca

Informatie en communicatie

Financiële dienstverlening en onroerend goed

Specialistische zakelijke diensten

Verhuur en overige zakelijke diensten

Openbaar bestuur en overheidsdiensten

Onderwijs

Gezondheidszorg

Welzijnszorg

Cultuur, sport en recreatie

Overige dienstverlening, huishoudens en extraterritoriale organisaties

Beroepsklassen, beroepssegment en onderliggende beroepsgroepen

\section{Pedagogische beroepen}

\section{Docenten}

Docenten hoger onderwijs en hoogleraren

Docenten beroepsgerichte vakken secundair onderwijs

Docenten algemene vakken secundair onderwijs

Leerkrachten basisonderwijs

Onderwijskundigen en overige docenten 
Sportinstructeurs

Sportinstructeurs

Leidsters kinderopvang en onderwijsassistenten

Leidsters kinderopvang en onderwijsassistenten

\section{Creatieve en taalkundige beroepen}

Auteurs en kunstenaars

Bibliothecarissen en conservatoren

Auteurs en taalkundigen

Journalisten

Beeldend kunstenaars

Uitvoerend kunstenaars

Vakspecialisten op artistiek en cultureel gebied

Grafisch vormgevers en productontwerpers

Fotografen en interieurontwerpers

\section{Commerciële beroepen}

Adviseurs marketing, public relations en sales

Adviseurs marketing, public relations en sales

Vertegenwoordigers en inkopers

Vertegenwoordigers en inkopers

Verkopers

Winkeliers en teamleiders detailhandel

Verkoopmedewerkers detailhandel

Kassamedewerkers

Callcentermedewerkers outbound en overige verkopers

Bedrijfseconomische en administratieve beroepen

Specialisten bedrijfsbeheer en administratie

Accountants

Financieel specialisten en economen

Bedrijfskundigen en organisatieadviseurs

Beleidsadviseurs

Specialisten personeels- en loopbaanontwikkeling

Vakspecialisten bedrijfsbeheer en administratie

Boekhouders

Zakelijke dienstverleners

Directiesecretaresses

Administratief personeel

Administratief medewerkers

Secretaresses

Receptionisten en telefonisten

Boekhoudkundig medewerkers

Transportplanners en logistiek medewerkers 


\section{Managers}

Algemeen directeuren

Algemeen directeuren

Managers op administratief en commercieel gebied

Managers zakelijke en administratieve dienstverlening

Managers verkoop en marketing

Managers productie en gespecialiseerde dienstverlening

Managers productie

Managers logistiek

Managers ICT

Managers zorginstellingen

Managers onderwijs

Managers gespecialiseerde dienstverlening

Managers horeca, detailhandel en overige diensten

Managers horeca

Managers detail- en groothandel

Managers commerciële en persoonlijke dienstverlening

Managers z.n.d.

Managers z.n.d.

Openbaar bestuur, veiligheid en juridische beroepen

Overheidsambtenaren en -bestuurders

Overheidsbestuurders

Overheidsambtenaren

Juristen

Juristen

Beveiligingswerkers

Politie-inspecteurs

Politie en brandweer

Beveiligingspersoneel

Militaire beroepen

\section{Technische beroepen}

Ingenieurs en onderzoekers wis-, natuur- en technische wetenschappen

Biologen en natuurwetenschappers

Ingenieurs (geen elektrotechniek)

Elektrotechnisch ingenieurs

Architecten

Vakspecialisten natuur en techniek

Technici bouwkunde en natuur

Productieleiders industrie en bouw

Procesoperators

Bouwarbeiders

Bouwarbeiders ruwbouw 
Timmerlieden

Bouwarbeiders afbouw

Loodgieters en pijpfitters

Schilders en metaalspuiters

Metaalarbeiders, machinemonteurs

Metaalbewerkers en constructiewerkers

Lassers en plaatwerkers

Automonteurs

Machinemonteurs

Voedselverwerkende beroepen en overige ambachten

Slagers

Bakkers

Productcontroleurs

Meubelmakers, kleermakers en stoffeerders

Medewerkers drukkerij en kunstnijverheid

Elektriciens en elektronicamonteurs

Elektriciens en elektronicamonteurs

Productiemachinebedieners en assemblagemedewerkers

Productiemachinebedieners

Assemblagemedewerkers

Hulpkrachten bouw en industrie

Hulpkrachten bouw en industrie

ICT- beroepen

Specialisten ICT

Software- en applicatieontwikkelaars

Databank- en netwerkspecialisten

Vakspecialisten ICT

Gebruikersondersteuning ICT

Radio- en televisietechnici

Agrarische beroepen

Tuinders, akkerbouwers en veetelers

Land- en bosbouwers

Hoveniers, tuinders en kwekers

Veetelers

Hulpkrachten landbouw

Hulpkrachten landbouw

Zorg-en welzijn beroepen

Artsen, therapeuten en gespecialiseerd verpleegkundigen

Artsen

Gespecialiseerd verpleegkundigen

Fysiotherapeuten 
Specialisten op maatschappelijk gebied

Maatschappelijk werkers

Psychologen en sociologen

Vakspecialisten gezondheidszorg

Laboranten

Apothekersassistenten

Verpleegkundigen (mbo)

Medisch praktijkassistenten

Medisch vakspecialisten

Sociaal werkers, groeps- en woonbegeleiders

Sociaal werkers, groeps- en woonbegeleiders

Verzorgenden

Verzorgenden

\section{Dienstverlenende beroepen}

Medewerkers persoonlijke dienstverlening

Reisbegeleiders

Koks

Kelners en barpersoneel

Kappers en schoonheidsspecialisten

Conciërges en teamleiders schoonmaak

Verleners van overige persoonlijke diensten

Schoonmakers en keukenhulpen

Schoonmakers

Keukenhulpen

Transport- en logistiek beroepen

Bestuurders voertuigen en bedieners mobiele machines

Dekofficieren en piloten

Chauffeurs auto's, taxi's en bestelwagens

Buschauffeurs en trambestuurders

Vrachtwagenchauffeurs

Bedieners mobiele machines

Hulpkrachten transport en logistiek

Laders, lossers en vakkenvullers

Vuilnisophalers en dagbladenbezorgers

\section{Overig}

Overig

Overig 


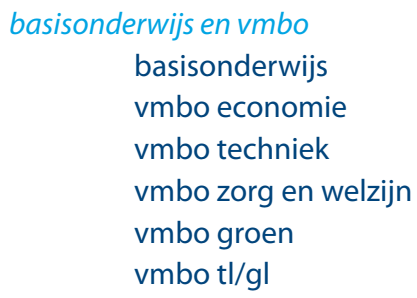

mbo 2/3 techniek

mbo $2 / 3$ media en vormgeving

mbo $2 / 3$ werktuigbouwkunde en metaalbewerking mbo $2 / 3$ technische installatie mbo $2 / 3$ operator mbo $2 / 3$ voertuigtechniek mbo $2 / 3$ techniek overig mbo $2 / 3$ bouw en infra mbo $2 / 3$ transport en logistiek

mbo 2/3 zorg en welzijn

mbo $2 / 3$ gezondheidszorg

mbo $2 / 3$ maatschappelijke zorg

mbo $2 / 3$ schoonheids- en haarverzorging

mbo 4 groen

mbo 4 voedsel, natuur en milieu 
mbo 4 economie

mbo 4 commercieel, financieel en administratief mbo 4 detailhandel

mbo 4 secretarieel

mbo 4 informatica

mbo 4 horeca

mbo 4 recreatie, vrijetijd en sport

mbo 4 facilitaire dienstverlening

mbo 4 techniek

mbo 4 media en vormgeving

mbo 4 werktuigbouwkunde en metaalbewerking

mbo 4 technische installatie

mbo 4 operator

mbo 4 voertuigtechniek

mbo 4 techniek overig

mbo 4 bouw en infra

mbo 4 transport en logistiek

mbo 4 zorg en welzijn

mbo 4 onderwijs

mbo 4 gezondheidszorg

mbo 4 maatschappelijke zorg

mbo 4 schoonheids- en haarverzorging

hbo onderwijs

hbo leraar basisonderwijs

hbo leraar algemene vakken

hbo leraar beroepsgerichte vakken

\section{hbo taal en cultuur}

hbo kunst

hbo communicatie

hbo journalistiek

\section{hbo economie}

hbo bedrijfseconomie

hbo marketing en commerciele economie

hbo accountancy en financiën

hbo bedrijfskunde en hrm

hbo recht

hbo hotel, vrijetijd en facility management 
hbo techniek

hbo informatica

hbo werktuigbouwkunde

hbo elektrotechniek

hbo chemie

hbo bouwkunde en civiele techniek

hbo transport en logistiek

hbo landbouw en natuur

hbo natuur en milieu

hbo landbouw

hbo gezondheidszorg

hbo verpleegkunde en medische diagnostiek

hbo fysiotherapie

hbo gedrag en maatschappij

hbo pedagogiek

hbo sociaal cultureel

hbo maatschappelijk werk

wo onderwijs

wo onderwijs

wo taal en cultuur

wo kunst

wo taal, cultuur en journalistiek

wo communicatie

wo economie en recht

wo economie

wo bedrijfseconomie en logistiek

wo accountancy en financiën

wo bedrijfskunde en hrm

wo recht

wo techniek

wo informatica

wo werktuigbouwkunde en elektrotechniek

wo bouwkunde en civiele techniek

wo landbouw en natuur

wo biologie, wiskunde, landbouw en milieu

wo natuur- en scheikunde 
wo medisch

wo (dier)geneeskunde en tandheelkunde wo gezondheidszorg

wo gedrag en maatschappij

wo politicologie en sociologie

wo psychologie en maatschappelijk werk

Overig

Overig 



\section{BIJLAGE C VERKRIJGBARE ARBEIDSMARKTINFORMATIE PER BEDRIJFSSECTOR, BEROEPSGROEP EN OPLEIDINGSTYPE}

Per bedrijfssector, beroepsgroep of opleidingstype (zie Bijlage B) zijn de hieronder weergegeven variabelen verkrijgbaar. De betreffende arbeidsmarktinformatie is afkomstig uit het Arbeidsmarktinformatiesysteem (AIS) van het ROA.

$\begin{array}{lll}\text { sector } & \text { beroeps- } & \text { opleidings- } \\ \text { groep } & \text { type }\end{array}$

actuele arbeidsmarktinformatie, gemiddelde 2013-2014

\begin{tabular}{|c|c|c|}
\hline aantal - werkenden & $x$ & $x$ \\
\hline aantal - werkenden in arbeidsvolume & $x$ & $x$ \\
\hline percentage - vrouwen & $x$ & $x$ \\
\hline percentage - niet-westerse allochtonen & $x$ & $x$ \\
\hline aantal - gemiddelde leeftijd & $x$ & $x$ \\
\hline percentage - jongeren (15-29) & $x$ & $x$ \\
\hline percentage - ouderen (55-74) & $x$ & $x$ \\
\hline percentage - vast dienstverband & $x$ & $x$ \\
\hline percentage - flexibel werk & $x$ & $x$ \\
\hline percentage - zelfstandig & $x$ & $x$ \\
\hline aantal - gemiddeld aantal uren werk per week & $x$ & $x$ \\
\hline percentage - deeltijd arbeid, minder dan 12 uur & $x$ & $x$ \\
\hline percentage - deeltijd arbeid, 12 tot 20 uur & $x$ & $x$ \\
\hline percentage - deeltijd arbeid, 20 tot 35 uur & $x$ & $x$ \\
\hline percentage - voltijd arbeid, 35 uur en meer & $x$ & $x$ \\
\hline percentage - overwerk & $x$ & $x$ \\
\hline percentage - ziekteverzuim in de afgelopen week & $x$ & $x$ \\
\hline percentage - midden- en kleinbedrijf & $x$ & $x$ \\
\hline percentage - trainingsintensiteit, $<6$ maanden & $x$ & $x$ \\
\hline percentage - trainingsintensiteit, $>=6$ maanden & $x$ & $x$ \\
\hline percentage - student/scholier & $x$ & $x$ \\
\hline \multicolumn{3}{|l|}{ aantal - potentiële beroepsbevolking } \\
\hline \multicolumn{3}{|l|}{ percentage - werkzame beroepsbevolking } \\
\hline \multicolumn{3}{|l|}{ percentage - werkloze beroepsbevolking } \\
\hline percentage - beschikbare niet-beroepsbevolking & & \\
\hline rcentage - niet beschikbare niet-beroepsbevolking & & \\
\hline
\end{tabular}


aantal - gemiddeld bruto uurloon (SSB2013)

indicator - indicator loopbaanperspectief

aantal - loonrisico, aantal euro per uur

percentage - opleidingsachtergrond basisonderwijs

percentage - opleidingsachtergrond vmbo

percentage - opleidingsachtergrond vmbo $\mathrm{tl} / \mathrm{gl}$

percentage - opleidingsachtergrond havo/vwo

percentage - opleidingsachtergrond mbo $2 / 3$

percentage - opleidingsachtergrond $\mathrm{mbo} 4$

percentage - opleidingsachtergrond hbo

percentage - opleidingsachtergrond wo

arbeidsmarktprognoses tot 2020

percentage en aantal- verwachte uitbreidingsvraag tot 2020

percentage en aantal- verwachte vervangingsvraag tot 2020

percentage en aantal-verwachte baanopeningen tot 2020

percentage en aantal- verwachte instroom van schoolverlaters tot 2020

indicator - ITKB toekomstige knelpunten beroepsgroep in 2020

indicator - ITKP toekomstige knelpunten personeelsvoorziening in 2020

$x$

$x \quad x$

$x \quad x$

$x \quad x$

$x \quad x$

$x \quad x$

indicator - ITA toekomstige arbeidsmarktsituatie in 2020

percentage- instroom met ITA goed/zeer goed

percentage- instroom met ITA slecht/matig

indicator - loopbaanperspectief

indicator - uitwijkmogelijkheden naar beroepsgroep

indicator - uitwijkmogelijkheden naar sector

indicator - substitutiemogelijkheden naar opleidingstype

indicator - conjunctuurgevoeligheid

indicator - concurrentieindex

actuele arbeidsmarktinformatie, gemiddelde 2013-2014

percentage - belangrijkste beroep per opleiding

percentage - belangrijkste sector per opleiding

percentage - belangrijkste opleiding per beroep

percentage - belangrijkste sector per beroep

percentage - belangrijkste opleiding per sector percentage - belangrijkste beroep per sector

schoolverlatersgegevens 2014

percentage - participatie in vervolgopleiding, studie

percentage - participatie in vervolgopleiding, $\mathrm{BBL}$

percentage - werkloosheid

percentage - intredewerkloosheid van 4 maanden of langer

percentage - vast dienstverband

percentage - flexibel werk

percentage - deeltijd arbeid, minder dan 12 uur

percentage - deeltijd arbeid, 12 tot 20 uur

percentage - deeltijd arbeid, 20 tot 35 uur

percentage - voltijd arbeid, 35 uur en meer

aantal - gemiddelde leeftijd 
percentage - buiten de vakrichting $\quad x$

percentage - onderbenutting $\quad x$

percentage - spijt van de gevolgde opleidng $\quad x$

aantal - gemiddeld bruto maandloon $\quad x$

aantal - gemiddeld aantal uren per week $x$

percentage - midden- en klein bedrijf $\quad x$

percentage - niet-westerse allochtonen $\quad x$

leerlingen 2014-2015 en gediplomeerden 2013-2014

aantal - leerlingen $x$

percentage - leerlingen - vrouw $\quad x$

percentage - leerlingen - BBL $\quad x$

percentage - leerlingen - deeltijd/duaal in hoger onderwijs $\quad x$

aantal-gediplomeerden $\quad x$

percentage - gediplomeerden - vrouw $\quad x$

percentage - gediplomeerden - BBL $\quad x$

percentage - gediplomeerden - deeltijd/duaal in hoger onderwijs $\quad x$

vacaturegegevens 2013-2014

percentage - vacatures $\quad x$

percentage - bedrijven met vacatures $\quad x$

percentage - bedrijven met vacatures - langer dan 3 maanden open $\quad x$

percentage - bedrijven met vacatures - moeilijk vervulbaar $\quad x$

arbeidsomstandigheden 2012

percentage - stank, lawaai, tocht of hoge/lage temperaturen $\quad x$

percentage - werken met gevaarlijke stoffen $\quad x$

percentage - werken onder gevaarlijke omstandigheden $\quad x$

percentage - lichamelijk zwaar werk $\quad x$

percentage - geestelijk zwaar werk $\quad x$

percentage - emotioneel zwaar werk $\quad x$

percentage - agressie op de werkplek $\quad x$

percentage - herhaling van dezelfde eenvoudige werkzaamheden $\quad x$

percentage - werken met mensen (patiënten, cliënten, enz.) $\quad x$

percentage - werk buiten mijn vak of beroep $\quad x$

percentage - zelf begintijd of eindtijd bepalen $\quad x$

percentage - werk in ploegendienst of wisselende diensten $\quad x$

percentage - werk met onregelmatige werktijden $\quad x$

percentage - werken in nachtdienst $\quad x$

percentage - werken op zaterdag $\quad x$

percentage - werken op zondag $\quad x$

percentage - zelf bepalen wáár u werkt (thuis, bij werkgever, of elders) $\quad$ x

verwachte knelpunten

- Knelpunten in de personeelsvoorziening naar bedrijfssector in $2020 \quad x$

- Knelpunten in de beroepsgroepen naar bedrijfssector in $2020 \quad x$

kernvaardigheden 2012

percentage - gebruikt computer op het werk $\quad x \quad x$

score - geletterdheid $\quad x \quad x$

score - gecijferdheid $\quad x \quad x$

score - probleemoplossend vermogen in een digitale omgeving $\quad x \quad x$ 



\section{BIJLAGE D LEEFTIJDSPIRAMIDE VAN DE WERKENDEN}

FIGUUR D1 Leeftijdsverdeling van de werkenden naar opleidingsniveau en geslacht, 1996-2014

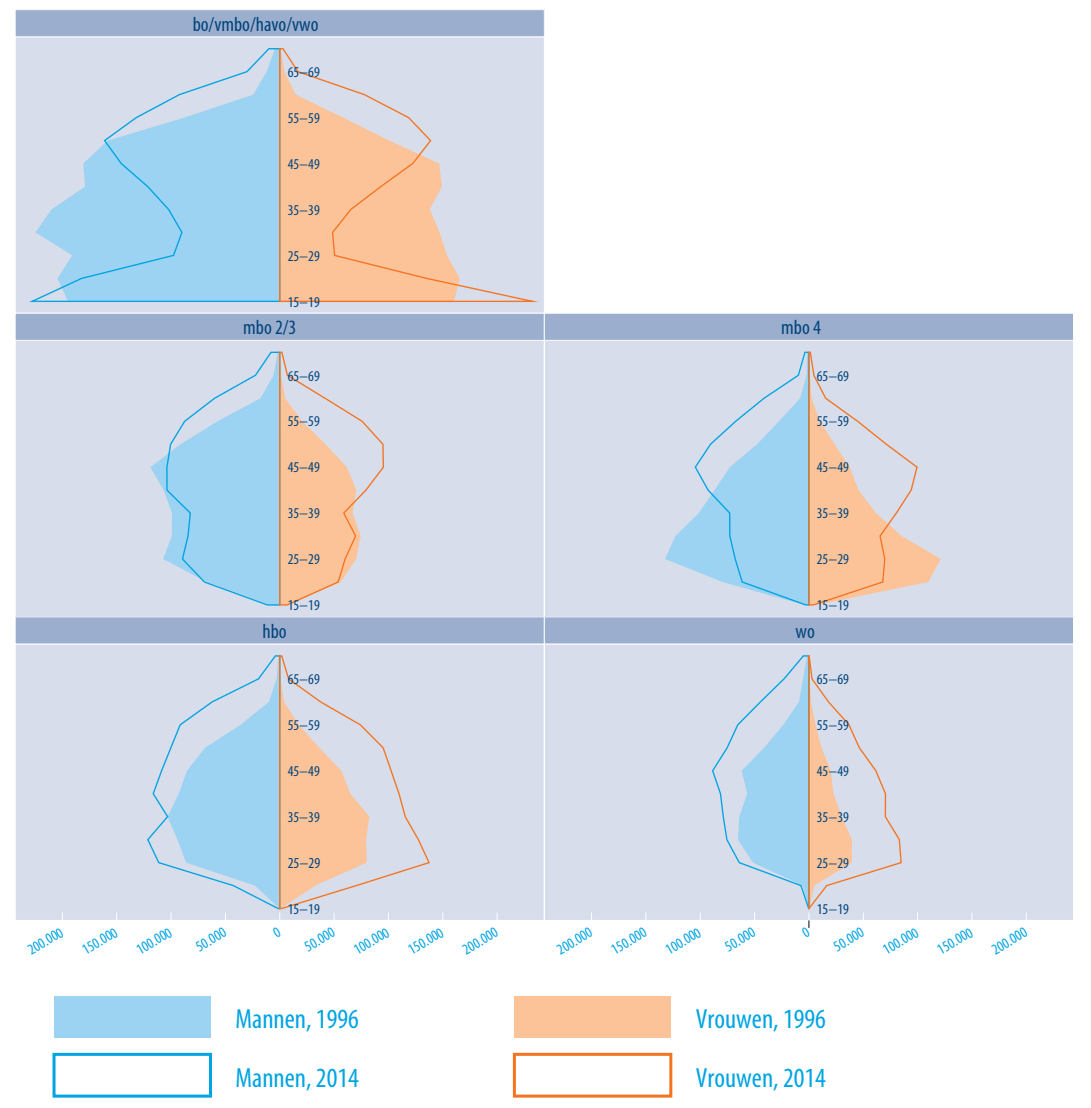





\section{BIJLAGE E STELLINGEN BEHORENDE BIJ DE ARBEIDSOMSTANDIGHEDEN EN ARBEIDSMARKTUITKOMSTEN}

Autonomie ( $1=$ nee, $3=$ ja, regelmatig) -6 items

Kunt $\mathrm{u}$ zelf beslissen hoe u uw werk uitvoert?

Bepaalt u zelf de volgorde van uw werkzaamheden?

Kunt u zelf uw werktempo regelen?

Moet $\mathrm{u}$ in uw werk zelf oplossingen bedenken om bepaalde dingen te doen?

Kunt $\mathrm{u}$ verlof opnemen wanneer $\mathrm{u}$ dat wilt?

Kunt u zelf bepalen op welke tijden u werkt?

Gevarieerd werk (schaal: $1=$ nooit $-4=$ altijd) -3 items

Is uw werk gevarieerd?

Vereist uw baan dat u nieuwe dingen leert?

Vereist uw baan creativiteit?

Innovatie (schaal: $1=$ nooit $-4=$ altijd) -4 items

Op mijn werk worden werknemers aangemoedigd om na te denken over manieren.... Ik mijn werk krijg ik tijd om nieuwe ideeën te ontwikkelen In mijn werk lever ik een duidelijke bijdrage aan het bedenken van... In mijn werk lever ik een duidelijke bijdrage aan het verbeteren van .... 
Researchcentrum voor Onderwijs en Arbeidsmarkt

Postbus 616

6200 MD Maastricht

$\mathrm{T}+31433883647$

F +31 433884914

secretary-roa-sbe@maastrichtuniversity.nl

www.roa.nl

Maastricht University

School of Business and Economics 